\title{
MUDANÇAS PALEOAMBIENTAIS NA REGIÃO DOS CERRADOS DO PLANALTO CENTRAL DURANTE O QUATERNÁRIO TARDIO: O ESTUDO DA LAGOA BONITA, DF
}

\author{
Maira Barberi
}

Orientador: Prof. Dr. Kenitiro Suguio

Co-Orientador: Profa. Dra. Maria Lea Salgado-Labouriau

TESE DE DOUTORAMENTO

Programa de Pós-Graduação em Geologia Sedimentar 
UNIVERSIDADE DE SÃO PAULO INSTITUTO DE GEOCIENNCIAS

\section{MUDANÇAS PALEOAMBIENTAIS NA REGIÃO DOS CERRADOS DO PLANALTO CENTRAL DURANTE O QUATERNÁRIO TARDIO: O ESTUDO DA LAGOA BONITA, DF}

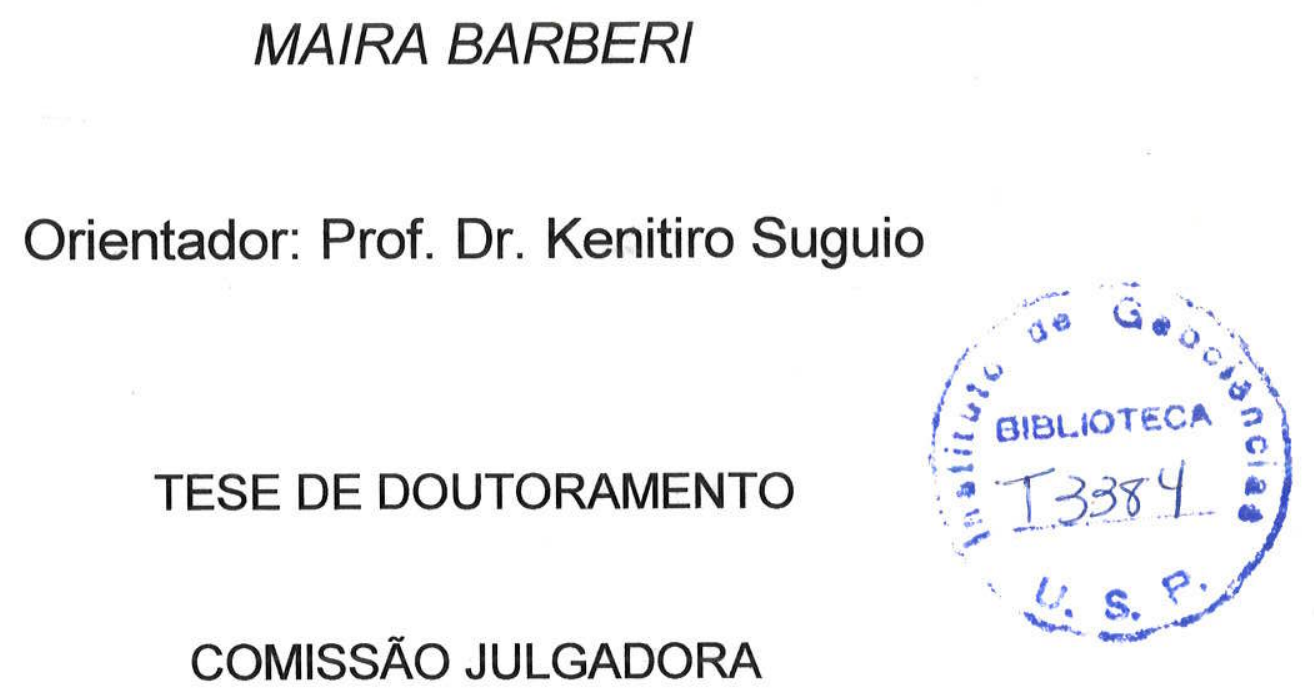

Nome

Presidente: Prof. Dr. Kenitiro Suguio

Examinadores: $\quad \mathrm{Dr}^{\mathrm{a} \cdot}$ Kátia Regina Ferraz Vicentini

Prof. Dr. Luiz Carlos Ruiz Pessenda

$\mathrm{Dr}^{\mathrm{a}}$. Marie Pierre Ledru

Prof. Dr. Paulo Cesar Fonseca Giannini

Assinatura

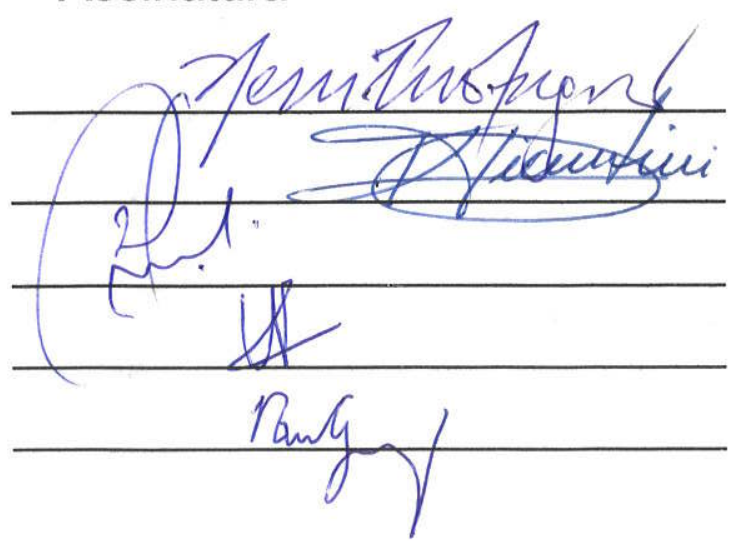

SÃO PAULO 


\section{UNIVERSIDADE DE SÃO PAULO \\ INSTITUTO DE GEOCIÊNCIAS}

\section{MUDANÇAS PALEOAMBIENTAIS NA REGIÃO DOS CERRADOS DO PLANALTO CENTRAL DURANTE O QUATERNÁRIO TARDIO:}

O ESTUDO DA LAGOA BONITA

Maira Barberi

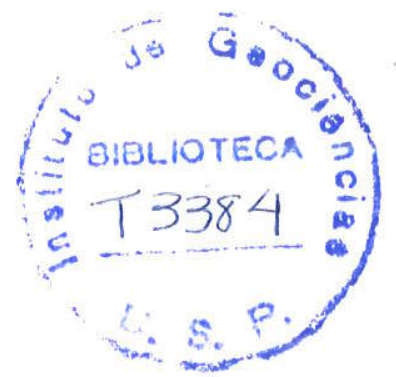

Orientador: Prof. Dr. Kenitiro Suguio

Co-Orientador: Prof. Dra. Maria Lea Salgado-Labouriau

TESE DE DOUTORAMENTO

Programa de Pós-Graduação em Geologia Sedimentar

\section{SÃO PAULO}

2001

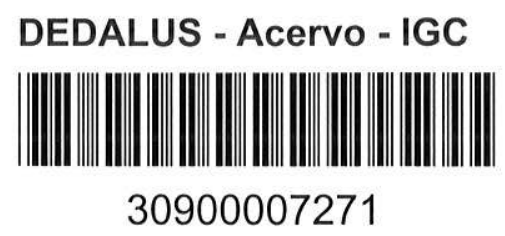




\section{Barberi, Maira}

Mudanças paleoambientais na região dos cerrados do Planalto Central durante o Quaternário tardio: $O$ estudo da Lagoa Bonita, DF/ Maira Barberi. São Paulo, 2001.

$X V, 210 p$. .il.

Tese (Doutorado): IGc/USP

Orient.: Suguio, Kenitiro

Co-orient.: Salgado-Labouriau, Maria Léa

1.Paleoecologia 2.Análise palinológica 3.Cerrado 4.Planalto Central 5.Paleoclimatologia I. Mudanças paleoambientais na região dos cerrados do Planalto Central durante 0 Quaternário tardio: 0 estudo da Lagoa Bonita, DF 


\section{DEDICATÓRIA}

Aos meus amigos que tornaram este trabalho possivel.

A todos aqueles que acreditam que a busca do conhecimento é o caminho para transformar as pessoas e o mundo. 


\section{AGRADECIMENTOS}

Ao professor Dr. Kenitiro Suguio pela oportunidade, pelos conhecimentos transmitidos e pela orientação.

À professora Dra. Maria Lea Salgado-Labouriau, pela orientação técnica e convivio que permitiu a consolidação da amizade, pela oportunidade de compartilhar sua estrada profissional e principalmente por tornar este trabalho uma fonte de prazer e de conhecimento, muito além do conhecimento técnico.

Ao Instituto de Geociências da Universidade de São Paulo pelo apoio institucional.

Ao Centro de Aperfeiçoamento de Professores do Ensino Superior CAPES, pela concessão da bolsa de doutorado.

À Vice-Reitoria de Pós-Graduação e Pesquisa da Universidade Católica de Goiás pela licença e em especial ao professor Dr. Nelson Jorge da Silva Jorge, vice-reitor de pesquisa e pós-graduação pelo apoio institucional.

Ao IRD (Institut de Recherche pour le Développement) pelas datações radiocarbônicas e pela sondagem do testemunho utilizado nesta pesquisa.

Ao Instituto de Geociências da Universidade de Brasília na pessoa do Dr. Demerval do Carmo por disponibilizar as instalações do Laboratório de Micropaleontologia onde foram efetuados os procedimentos de preparação do material para análise palinológica.

Ao Instituto de Geociências da Universidade de Brasilia, pelas análises de difração de raios-X e em especial à professora Dra. Edi Guimarães, coordenadora do laboratório, pela orientação na análise mineralógica e revisão do texto além do apoio e amizade.

À professora MSc. Marta Regina Magalhães coordenadora do Centro de Estudos e Pesquisas Biológicas da Universidade Católica de Goiás, pelo apoio institucional na efetivação do Laboratório de Paleoecologia. 
À secretaria de Pós-graduação do Instituto de Geociências da Universidade de São Paulo, nas pessoas de Ana Paula Cabanal e Magali Poli Fernandes Rizzo, pela competência, eficiência e atenção, muito além de suas obrigações, para com esta aluna distante fisicamente.

À Dra. Katia Regina Ferraz-Vicentini pela orientação e auxílio na utilização do Programa Tillia, pelas discussões proveitosas, mas principalmente pela amizade e apoio.

Ao professor. Dr. Fabrizio D' Áyala Valva da Universidade Federal de Goiás por acreditar neste trabalho e se dispor a concretizar uma parceria na busca de apoio financeiro para a montagem do laboratório de Paleoecologia na Universidade de Goiás. Meu desejo de que esta parceria tenha vida longa.

Ao $\mathrm{CNPq}$ pelo apoio financeiro na montagem do Laboratório de Paleoecologia, espaço fundamental para a finalização deste trabalho e para a concretização de trabalhos futuros.

Ao geólogo Jofre Valmório de Lacerda Filho, gerente de recursos minerais da Companhia de Pesquisa de Recursos Minerais - GO, pelo apoio institucional, mas principalmente pela amizade e incentivo.

A Dra. Lindinalva Mamede do IBGE pelas discussões valiosas, auxílio, apoio e amizade.

Ao geólogo Péricles Prado pela confecção dos mapas, pela paciência com minhas solicitações, mas principalmente pela nova amizade.

Aos professores Júlio Cezar Rubin de Rubin e Rosiclér Theodoro da Silva pelas discussões técnicas, por acreditarem que juntos poderemos construir uma nova linha de pesquisa sob condições tão adversas como as que vigoram longe dos grandes centros de pesquisa, por se disporem a tentar comigo, mas principalmente pela amizade, auxílio e apoio.

Ao professor e amigo Dr. Altair Sales Barbosa por disponibilizar material inédito.

A professora Maria Cira Jorge Meirelles, pela revisão criteriosa do texto, pelo incentivo constante, mas principalmente por sua amizade preciosa.

Aos monitores e estagiários, Fernanda, Flávia, Lílian, Luciano e Mateus, mais que alunos, companheiros de trabalho e amigos. 
Aos amigos Gislene Lisboa, Elizabete Santana, Eleno de Paula Rodrigues e Wilson Ribeiro Filho pelo apoio, auxílio, incentivo e amizade.

Ao engenheiro agrônomo MSc Orione Alvares da Silva pelo apoio e incentivo, pela elaboração dos programas de análises dos dados palinológicos, pelas inúmeras discussões técnicas, pela parceria no projeto do $\mathrm{CNPq}$, pela longa, constante e agradável parceria nos trabalhos de campo, por disponibilizar a infra-estrutura, mas principalmente pela amizade.

Aos amigos de todas as horas, através dos quais pude ter acesso aos equipamentos, análises, informações, bibliografias, e as mais diferentes e necessárias formas de auxílio, além de apoio e incentivo. Vocês tornaram este trabalho possivel e a vocês ele é dedicado.

À minha familia, amiga de todas as horas e sempre tão presente e solidária para com a minha busca de conhecimentos, se dispondo a me auxiliar por infinitos meios. Em especial, um agradecimento às minhas filhas Mariana e Roberta, minha mãe Maria Hermínia e meu irmão Carlos. Este trabalho é de vocês também.

Ao arquiteto Rogerio Batagliesi pelo apoio durante a execução deste trabalho, pelo auxílio financeiro e pelo seu interesse em um assunto tão distante de sua área de atuação. Seu incentivo foi fundamental para a finalização deste trabalho que é dedicado a você em especial, meu amigo de mais longa data. 


\section{SUMÁRIO}

DEDICATÓRIA

AGRADECIMENTOS N iN

INDICE DE FIGURAS iX

ÍNDICE DE TABELAS $\quad x i$

RESUMO Xii

ABSTRACT Xiv

1. INTRODUÇÃO 1

1.1 Objetivos 6

2. CARACTERIZAÇÃO DA ÁREA DE ESTUDO 7

2.1 Localização 7

2.2 Hidrografia 9

2.3 Geologia 11

2.3.1 Geologia Regional 11

2.3.2 Geologia Local 13

2.4 Geomorfologia 16

2.5 Solos 19

2.6 Clima 21

2.7 Vegetação 25

2.7.1 O bioma Cerrado 25

2.7.2 História evolutiva do Cerrado 30

2.7.3 Ocupação do bioma Cerrado no Planalto Central 38

2.7.4 Vegetação da área de estudo 53

3. METODOLOGIA 63

3.1 Atividades de campo 63

$\begin{array}{lll}3.2 & \text { Atividades de laboratório } & 64\end{array}$ 
3.2.1 Análise mineralógica $\quad$ - $\quad 65$

3.2.2 Análise palinológica 66

3.2.2.1 Fundamentos 66

3.2.2.2 Preparação do sedimento 69

3.2.2.3 Análise do material ao microscópio 72

3.2.2.4 Organização dos dados $\quad 74$

3.2.2.5 Apresentação dos diagramas de palinomorfos 76

4. RESULTADOS 82

4.1 Descrição do testemunho 82

4.2 Análise mineralógica por difração de raios $X \quad 87$

4.3 Análise palinológica 93

$\begin{array}{lll}4.4 & \text { Síntese } & 122\end{array}$

5. DISCUSSÕES 125

5.1 Dados Paleoecológicos $\quad 125$

$\begin{array}{lll}5.2 & \text { Dados Arqueológicos } & 147\end{array}$

6. CONCLUSÕES 153

REFERÊNCIAS BIBLIOGRÁFICAS

ANEXOS 172

ANEXO $01 \quad$ Registro fotográfico dos tipos polínicos 172

ANEXO 02 TABELA 3.1: Relação de tipos polínicos do sedimento da Lagoa Bonita, DF 180

ANEXO 03 TABELA 3.2: Variáveis físicas e biológicas utilizadas no cálculo da concentração

ANEXO 04 TABELA 3.3: Qualificação e quantificação dos tipos polínicos da Lagoa Bonita, DF

\section{APÊNDICE}

APÊNDICE A Difratogramas do sedimento da Lagoa Bonita, DF 


\section{LISTA DE FIGURAS}

FIGURA 2.1 Vista geral da Lagoa Bonita, Planaltina, DF 7

FIGURA 2.2 Localização da área de estudo 8

FIGURA 2.3 Rede de drenagem e indicação da área que corresponde ao divisor das bacias hidrográficas dos rios Amazonas e Paraná

FIGURA 2.4 Mapa geológico simplificado do Distrito Federal 15

$\begin{array}{lll}\text { FIGURA 2.5 Mapa geomorfológico } & 18\end{array}$

$\begin{array}{lll}\text { FIGURA 2.6 Mapa pedológico } & 20\end{array}$

FIGURA 2.7 Sistemas de circulação atmosférica e diferenciações climáticas considerando em conjunto os regimes térmico e pluviométrico 23

FIGURA 2.8 Distribuição do bioma Cerrado 26

FIGURA 2.9 Localização dos sítios arqueológicos na América do Sul ao final do Pleistoceno

FIGURA 2.10 Distribuição da Tradição Itaparica 44

FIGURA 2.11 Artefatos líticos plano-convexos trabalhados como raspadores, característicos da Tradição Itaparica $\quad 46$

FIGURA 2.12 Distribuição da vegetação regional 55

FIGURA 2.13 Distribuição da vegetação regional em $1997 \quad 56$

FIGURA 2.14 Distribuição da vegetação no entorno da Lagoa Bonita 57

FIGURA 2.15 Aspecto característico do Cerrado Típico do entorno da Lagoa Bonita, DF $\quad 59$

FIGURA 2.16 Diagrama de perfil (1) e cobertura arbórea (2) de um Cerrado Típico representando uma faixa de $40 \mathrm{~m}$ de comprimento por $10 \mathrm{~m}$ de largura

FIGURA 2.17 Aspecto característico de um Campo Limpo Úmido do entorno de lagoas na região de Planaltina, DF

FIGURA 2.18 Aspecto característico da Vereda localizada junto à Lagoa Bonita, DF

FIGURA 2.19 Diagrama de perfil (1) e cobertura arbórea (2) de uma vereda representando uma faixa de $40 \mathrm{~m}$ de comprimento por $10 \mathrm{~m}$ de largura 
FIGURA 3.1 Estratigrafia e indicação das amostras para dațação radiocarbônica, análise palinológica e mineralógica do testemunho da Lagoa Bonita

FIGURA 3.2 Exemplos de curvas de saturação dos niveis 9 e 20

FIGURA 3.3 Indicação dos 40 elementos utilizados para a determinação das ecozonas do sedimento da Lagoa Bonita

FIGURA 4.1 Estratigrafia, datação radiocarbônica, datas extrapoladas e conteúdo mineralógico em proporçōes relativas de quartzo e argilominerais do testemunho da Lagoa Bonita

FIGURA 4.2 Diagrama de porcentagem dos tipos polínicos da Lagoa Bonita

FIGURA 4.3 Diagrama de porcentagem dos diferentes tipos de hábitos 104

FIGURA 4.4 Diagrama de porcentagem das diferentes fitofisionomias 105

FIGURA 4.5 Diagrama de porcentagem dos diferentes tipos de Vegetação

FIGURA 4.6 Diagrama de porcentagem dos palinomorfos em curvas Expandidas

FIGURA 4.7 Diagrama de concentração dos diferentes tipos de Palinomorfos

FIGURA 4.8 Diagrama de concentração dos elementos arbóreos de Vereda e Mata - I

FIGURA 4.9 Diagrama de concentração de elementos arbóreos de Mata - II

FIGURA 4.10 Diagrama de concentração de elementos arbóreos de Cerrado e outros elementos arbóreos

FIGURA 4.11 Diagrama de concentração de elementos herbáceos e outros elementos - 1

FIGURA 4.12 Diagrama de concentração de elementos herbáceos e e outros elementos - II

FIGURA 4.13 Diagrama de concentração de elementos palustres, Pteridófitas e algas

FIGURA 4.14 Diagrama de concentração dos tipos de vegetação

FIGURA 4.15 Histograma de concentração das partículas de carvão do sedimento e das amostras de superfície da Lagoa Bonita 116

FIGURA 4.16 Histograma de porcentagem dos elementos arbóreos e herbáceos das amostras de superfície da Lagoa Bonita e da Vereda de Águas Emendadas 
FIGURA 4.17 Histograma de porcentagem dos elementos palustres, Pteridófitas, algas e fungos das amostras de superficie da Lagoa Bonita e da Vereda de Águas Emendadas

FIGURA 4.18 Histograma de concentração dos elementos arbóreos das amostras de superfície da Lagoa Bonita e da Vereda de Águas Emendadas

FIGURA 4.19 Histograma de concentração dos elementos herbáceos e outros elementos das amostras de superfície da Lagoa Bonita e da Vereda de Águas Emendadas

FIGURA 4.20 Histograma de concentração dos elementos palustres, Pteridófitas, algas e fungos das amostras de superficie da Lagoa Bonita e da Vereda de Águas Emendadas

FIGURA 4.21 Perfis esquemáticos representando a evolução da

Paisagem na Lagoa Bonita durante o Quaternário tardio

FIGURA 5.1 Mapa de localização das áreas de estudos com análises palinológicas

\section{LISTA DE TABELAS}

TABELA 4.1 Datações radiocarbônicas e taxas de sedimentação Lagoa Bonita

TABELA 5.1 Síntese das características físicas das áreas analisadas 


\section{RESUMO}

A presente pesquisa versa sobre a evolução paleoambiental, principalmente paleoclimática, no decorrer do Pleistoceno tardio - Holoceno, de uma área atualmente recoberta por cerrados, localizada no Planalto Central Brasileiro, a nordeste do Distrito Federal.

As interpretações paleoecológicas foram baseadas nas análises palinológica e mineralógica do sedimento contido em um testemunho de sondagem obtido na seqüência estratigráfica depositada na Lagoa Bonita, DF.

As datações radiocarbônicas permitiram estabelecer as idades das diferentes fases da sedimentação e o início de formação da lagoa, há aproximadamente 26.000 anos AP - Antes do Presente (idade extrapolada).

$A$ análise palinológica, baseada em diagramas de porcentagem e de concentração dos palinomorfos preservados no sedimento, permitiu estabelecer, através de procedimentos estatísticos, sete ecozonas que evidenciam modificações na composição e distribuição da vegetação durante o Quaternário tardio - Holoceno, provocadas provavelmente por mudanças paleoclimáticas.

A análise mineralógica por difratometria de raios- $X$, possibilitou a identificação dos argilominerais, complementando as informações palinológicas, principalmente em intervalos onde não há registro de palinomorfos. Esta abordagem interdisciplinar mostrou-se bastante eficiente em estudos paleoecológicos.

A evolução paleoambiental da região da Lagoa Bonita é marcada por dois intervalos com características distintas quanto ao conteúdo e distribuição da vegetação, separados por uma fase quando vigoravam condições mais secas que no presente.

Embora ocorram oscilações nos dois intervalos identificados, as quais possibilitaram a definição das ecozonas, a sequêencia inferior, posicionada no Pleniglacial superior, é representada por um conjunto com predominância de elementos arbóreos e palustres, indicando um clima mais úmido e frio que o atual. 
A seqüência superior, depositada a partir do Glacial tardio é marcada pelo predomínio de elementos de cerrado indicando um clima com duas estações (bissazonal), com a implantação da vereda, identificada a partir da ocorrência de Mauritia, na parte superior, por volta de $6.300 \pm 40 \mathrm{AP}$.

As alterações ocorridas durante o Pleistoceno tardio no Planalto Central, são correlacionáveis às mudanças registradas em outras áreas das terras baixas tropicais e estão associadas às modificações climáticas da fase final da última glaciação Würm (Wisconsin) do Hemisfério Norte. 


\section{ABSTRACT}

This research deals with the palaeoenvironmental, mainly palaeoclimatic evolution, during the Late Pleistocene - Holocene, of an area, presently covered by savannas, and located in the Central Brazilian High Plains, in the northeastern region of the Federal District, Brazil.

The palaeoecological interpretations of this research were based on the palynological and mineralogical analyses of lake sediment samples from a $3.5 \mathrm{~m}$ long core of Lagoa Bonita, Central Brazil. The ages of the different sedimentation phases, as well as that of the onset of the lake about 26,000 yrs BP, were obtained by radiocarbon analyses.

The palynological analysis, based on concentration and percentage diagrams of the palynomorphs preserved in the sediment, coupled with statistical procedures, fermitted the establishment of seven ecological zones. They show variations in the composition and distribution of different vegetation types, during the Late Pleistocene and Holocene, which were probably caused by climatic changes.

The X-ray diffraction analysis of sediment samples allowed the identification of the clay minerals, complementing the palynological information, mainly in intervals without pollen record. This interdisciplinary approach has been efficiently used in various palaeoecological studies.

The palaeoenvironmental evolution of Lagoa Bonita is marked by sedimentary episodes, characterized by two different phases of vegetational composition and distribution, separed by a phase during which semi-arid conditions were present.

Although there were fluctuations in the two identified periods, the lower sequence, located in the Upper Pleniglacial, is represented by a set of predominantly arboreal and swamp elements, indicative of a more humid and cold climate than at present. The upper sequence, deposited after the Late Glacial Maximum, is marked by savanna elements, and by the establishment of Mauritia palm swamp vegetation, around $6,300 \pm 40 \mathrm{BP}$. 
The changes occurred during the Late Pleistocene, can be correlated with changes recorded in other areas of tropical lowlands and are associated to the last glacial period Würm (Wisconsin) of the Northern Hemisphere. 


\section{INTRODUÇÃO}

Os estudos paleoambientais representam importante fonte de dados para a compreensão dos diferentes ecossistemas e de suas alteraçōes no decorrer do tempo geológico, as quais podem ocorrer por ação antrópica ou por mudanças naturais do clima.

O clima constitui um fator decisivo na dinâmica superficial da Terra, controlando não só a distribuição dos organismos, como o tipo e a intensidade de atuação dos processos intempéricos e erosivos. Embora as modificações paleoclimáticas possam ser estabelecidas a partir de estudos paleoecológicos, o reconhecimento das causas é bastante complexo.

Segundo Suguio (1999), no controle das modificações interage uma série de fatores que incluem variaçōes nos parâmetros orbitais da terra, aos quais se somam ou subtraem fatores de dinâmica interna, que controlam a formação e o posicionamento de cadeias de montanhas. Atuando também neste conjunto de variảveis destacam-se os fatores da dinâmica externa, que inclui o tipo de clima, resultante da interação de parâmetros como latitude e altitude e sistemas de circulação atmosférica.

Desta forma, a resposta final do ambiente às modificações climáticas, é consequeencia da interação de fatores de caráter mundial, com elementos regionais e locais, onde novos parâmetros, como altitude, condicionamentos geológico, geomorfológico e pedológico, contribuem para a configuração deste quadro bastante complexo.

Uma das principais ferramentas para se efetivar estudos paleoecológicos é representada pela paleopalinologia que permite, a partir da análise de espectros de palinomorfos preservados em sedimentos, o estudo qualitativo, quantitativo e estatistico das alterações ocorridas nas comunidades vegetais, em função de modificaçōes climáticas. Este tipo de estudo, quando envolve outras análises, procurando contemplar o caráter interdisciplinar da paleoecologia, permite obter melhores interpretaçöes, além de preencher lacunas quando não há registro de palinomorfos. 
Modificações na paisagem do território brasileiro, jă haviam sido sugeridas por Ab'Saber (1977) e Ab'Saber \& Bigarella (apud Bigarella et al., 1994), que apontavam para uma série de discrepâncias entre as condições ambientais atuais e as feições geomorfológicas, embora com pouco suporte de dados sistemáticos e quantitativos, principalmente de datações.

Posteriormente, estudos de caráter mais sistemático, baseados em análises palinológicas de sedimentos lacustres e de turfeiras, foram realizados na região andina e em terras baixas tropicais da América do Sul, revelando marcantes variaçōes no conteúdo e distribuição dos palinomorfos, evidenciando importantes modificações ambientais relacionáveis às glaciaçōes pleistocênicas.

Alterações na paisagem também foram registradas no Holoceno, sendo relacionadas, por alguns autores, à anomalias climáticas do tipo "El Niño", onde as modificações na circulação das massas de ar constituem respostas à atuação de forças astronômicas (Martin et al., 1993; 1995; 1997; Turcq et al., 1993; Suguio et al., 1996).

Em razão do nível de detalhamento maior fornecido pela análise palinológica, associado à possibilidade de datação radiocarbônica de sedimentos lacustres e de turfeiras do Pleistoceno tardio - Holoceno, trabalhos utilizando o registro de palinomorfos, têm sido desenvolvidos, nas terras baixas tropicais, em áreas atualmente recobertas pela floresta tropical úmida e pelos cerrados, procurando estabelecer a dinâmica da vegetação e as modificações climáticas durante o Quaternário tardio.

Nos Llanos Orientais da Colômbia, em áreas recobertas pelos cerrados, o registro dos sedimentos lacustres indica que o cerrado esteve estável nos últimos 18.000 anos, com pequenas mudanças na proporção floresta/cerrado, relacionadas à fase mais seca durante o Último Máximo Glacial (UMG). Condiçōes mais úmidas, com a expansão da floresta de galeria, são registradas por volta de 10.700 anos AP (Antes do Presente), permanecendo durante o Holoceno, com pequenas variações (Behling \& Hooghiemstra, 1999).

Dados palinológicos, provenientes de Rondônia, da Serra dos Carajás e das Guianas, sugerem uma fragmentação da floresta tropical, com expansão dos cerrados, indicando queda na precipitação e na temperatura, durante parte do Pleniglacial superior (22.000 a 13.000 AP), com retorno de condições úmidas a 
partir do Glacial tardio e início do Holoceno (13.000 a 10.000 AP) (Absy et al., 1991; van der Hammen \& Absy, 1994).

Registro de condições mais secas que as atuais na Amazônia, durante o final do Pleistoceno, foram obtidos também, a partir da análise dos tipos de depósitos sedimentares e de processos de dinâmica superficial (Clapperton, 1993; Iriondo \& Latrubesse, 1994).

Trabalhos interdisciplinares desenvolvidos na Serra dos Carajás (PA), abordando partículas de carvão e análises química e microscópica dos sedimentos lacustres, além de estudos palinológicos, evidenciaram mudanças climáticas nos últimos 30.000 anos AP, com ênfase para o Holoceno, a partir de 7.000 anos AP, quando foram registradas fases com freqüência variável de eventos de incêndios, associados a episódios curtos de seca (Sifeddine et al., 1994; Cordeiro, 1995; Turcq et al., 1998).

Na porção oeste da Amazônia, na região do Alto Rio Negro, embora não ocorra registro de fragmentação da floresta, a presença de espécies atualmente restritas às altas elevações condicionadas pela temperatura, indica uma queda na temperatura da ordem de 5 a $6^{\circ} \mathrm{C}$, por volta de 40.000 anos AP (Colinvaux et al.; 1996; De Oliveira, 1996)

No estado da Bahia, em áreas atualmente recobertas pela caatinga, os estudos palinológicos da Turfa do Saquinho, situada no sistema de dunas fixadas do Médio Rio São Francisco, indicam que o atual sistema de drenagem só se instalou após o término da fase glacial. $O$ aumento expressivo da umidade, ao final do Pleistoceno, com temperaturas mais baixas que a atual, resultou na expansão da floresta tropical úmida, com elementos da Amazônia e da Floresta Atlântica, que alcançaram a área através de uma ampla rede de floresta de galeria, provocando uma alta biodiversidade (De Oliveira et al., 1999).

Durante o Holoceno, as variaçōes nas condições climáticas são associadas às fases com ocorrência freqüente de incêndios, e as discrepâncias da regiäo do médio rio São Francisco com relação ao Centro Oeste e Centro Sul do Brasil, nos últimos 5000 anos, são atribuidas por Barreto et al. (1996) a efeitos de eventos paleoclimáticos tipo "El Niño", produzindo periodos prolongados de paleoclimas mais secos no Nordeste e Amazônia. 
Os resultados de análises palinológicas para áreas de cerrados de Minas Gerais, nas lagoas dos Olhos e de Serra Negra, indicam temperaturas mais baixas e maior taxa de umidade durante o Pleniglacial Médio (65.000 a 28.000 AP), seguido de uma fase mais seca durante o Último Máximo Glacial (De Oliveira, 1992).

O registro das alteraçōes climáticas, durante o Holoceno nos cerrados de Minas Gerais, na região da Lagoa Santa, é apresentado com base em análise de pólen e na evolução geomorfológica da área da bacia, evidenciando a instalação de condições mais úmidas por volta de 5.400 anos AP, que possibilitaram a formação de um pântano e posterior evolução para uma lagoa (Parizzi, 1993; Parizzi et al., 1998).

$\mathrm{Na}$ Serra do Salitre, em Minas Gerais, estudos interdisciplinares em sedimentos lacustres e no solo, envolvendo análises palinológica, mineralógica, do conteúdo de matéria orgânica e de carvão, permitiram estabelecer as mudanças climáticas a partir do Pleistoceno tardio até o Holoceno (Vernet et al., 1994; Bertaux et al., 1996; Ledru,1991; 1993; Ledru et al., 1996; Alexandre \& Meunier, 1999).

Uma fase fria e úmida com a presença de Araucária na passagem do Pleniglacial Médio a Superior, é seguida por uma fase seca e fria, que se estende até cerca de 16.000 AP. No início do Glacial tardio, voltam a vigorar condições de maior umidade, porém com temperaturas ainda frias. O Holoceno inicial é caracterizado por um padrão sazonal mais marcado, com elevação de temperatura até cerca de 5.000 anos, e posteriormente, a volta da umidade, atestada pelo espalhamento da floresta semi-descídua.

Nas áreas de cerrados do Brasil Central, os estudos realizados em Crominia, GO (Ferraz-Vicentini, 1993; Ferraz-Vicentini \& Salgado-Labouriau, 1996; Salgado-Labouriau et al., 1997; 1998), na Chapada dos Veadeiros e na Lagoa Feia em Goiás (Ferraz-Vicentini, 1999) e na Vereda de Águas Emendadas, no Distrito Federal (Barberi, 1994; 1998; Barberi et al., 1995; 2000), apontam para uma tendência geral paleoclimática, durante o Pleistoceno tardio e o Holoceno, sintetizada por Salgado-Labouriau (1997) e Salgado-Labouriau et al. (1998).

Nessas áreas, após uma fase úmida e fria que se estende do final do Pleniglacial Médio até o Pleniglacial Superior por volta de 20.000 anos AP, segue- 
se um prolongado período seco, bastante acentuado em Águas Emendadas, que perdura nas demais áreas atè o inicio do Glacial tardio por volta de 13.000 anos AP. O início do Holoceno é marcado pelo retorno das condições úmidas e por um aumento gradativo da temperatura.

As variaçōes nas idades dos eventos registrados em diferentes áreas do planalto central estão provavelmente relacionadas às diferenças de latitude e às diferenças nas características dos relevos locais. $O$ retorno efetivo da umidade para as áreas atualmente recobertas pelos cerrados, se dá a partir de 8.000 AP com a instalação de condições semelhantes às atuais, por volta de 4.000 AP. 0 registro da atuação do fogo encontra-se bem marcado, ocorrendo a partir do Pleniglacial Médio, com fases de intensificação durante 0 Holoceno, eventualmente associadas à presença do homem no Planalto Central Brasileiro (Salgado-Labouriau \& Ferraz-Vicentini, 1994; Barbosa et al., 1994)

A partir das pesquisas desenvolvidas nas regiōes central e sudeste do Brasil, Ledru et al. (1998) e Behling (1998) apresentam uma sintese para o Quaternário tardio. Estes dados apontain, durante o Holoceno, para a presença de condiçōes áridas até cerca de $7.000 \mathrm{AP}$, e para a influência da corrente de adveç̧ão polar, que nesta época atingiria latitudes tropicais, induzindo condiçōes mais frias e úmidas, nas áreas situadas ao longo da sua trajetória. Após 7.000 AP ocorre um aumento contínuo da umidade até atingir os valores atuais, por volta de 2.500 anos AP.

De modo geral, a partir dos trabalhos de cunho paleoecológico, desenvolvidos nas terras baixas tropicais da América do Sul, é possível levantar hipóteses sobre a dinâmica da vegetação durante o Quaternário, envolvendo áreas atualmente recobertas por fitofisionomias diversas como a floresta tropical úmida, os cerrados e a caatinga e analisar as teorias para a formação dos cerrados, sintetizadas por Alvim (1996).

A origem dos cerrados como bioma tem se constituido em uma questão polêmica, que resultou em três grandes enfoques. A teoria climática, proposta inicialmente por Warming (1908), que relacionou os cerrados a uma deficiência sazonal de água durante períodos relativamente longos, teoria esta questionada de forma enfática por Ferri (1979). A teoria pedológica que considera a influência dos solos quanto aos aspectos de fertilidade e capacidade de drenagem na 
formação dos diferentes tipos de vegetação, cujos primeiros trabathos de caráter experimental foram apresentados por Alvim e Araújo (1952), e a teoria biótica que considera os cerrados como resultante da ação do homem através do uso freqüente de queimadas, que segundo Warming (1908) e Rawistscher (1948) teve em Peter Lund seu primeiro defensor.

De modo geral, as áreas interiores são marcadas pela escassez de depósitos extensos e contínuos do Pleistoceno devido à maior estabilidade tectônica, onde os registros de neotectônica săo principalmente de caráter local e não regional. Aliado a este fato, o tipo de processos morfoclimáticos atuantes desde o Paleógeno que não favoreceram a acumulaçăo de sedimentos associados à matéria orgânica, faz com que cada registro encontrado torne-se de fundamental importância para a compreensão da evolução da paisagem de áreas atualmente recobertas pelos cerrados e sua gênese.

\subsection{Objotivos}

O objetivo desta pesquisa é propor a evoluçăo da paisagem e os fatores climáticos que atuaram no controle das modificaçōes registradas na composição e distribuiçăo da vegetação, na regiăo nordeste do Distrito Federal, durante o Pleistoceno tardio e Holoceno, verificar a amplitude dos processos responsáveis pelas mudanças paleoclimáticas, bem como fornecer subsidios para novas análises sobre a gênese dos cerrados que levem em consideração os dados paleoecológicos e arqueológicos. 


\section{CARACTERIZAÇÃO DA AREA DE ESTUDO}

\subsection{Localização}

O estudo compreende a região da Lagoa Bonita ou Mestre D'Armas (Figura 2.1), no norte-nordeste do Distrito Federal, cerca de $7 \mathrm{~km}$ a noroeste da cidade Planaltina, DF. A Lagoa Bonita, denominação adotada ao longo do texto, embora apresente atualmente uma área maior que a original resultante do represamento, tem sua porção central situada a $15^{\circ} 35^{\prime}$ de latitude $S$ e $47^{\circ} 41^{\prime}$ de longitude WGr. A partir de 1981, a lagoa e a região do entorno que se encontrava em processo acelerado de degradação, foi incluída na Reserva Biológica de Águas Emendadas, a qual com o decreto número 11.137 de 16/06/88 passou a constituir a Estação Ecológica de Águas Emendadas, compreendendo uma área total de cerca de 50.000 hectares (SEMATEC, 1996) (Figura 2.2).

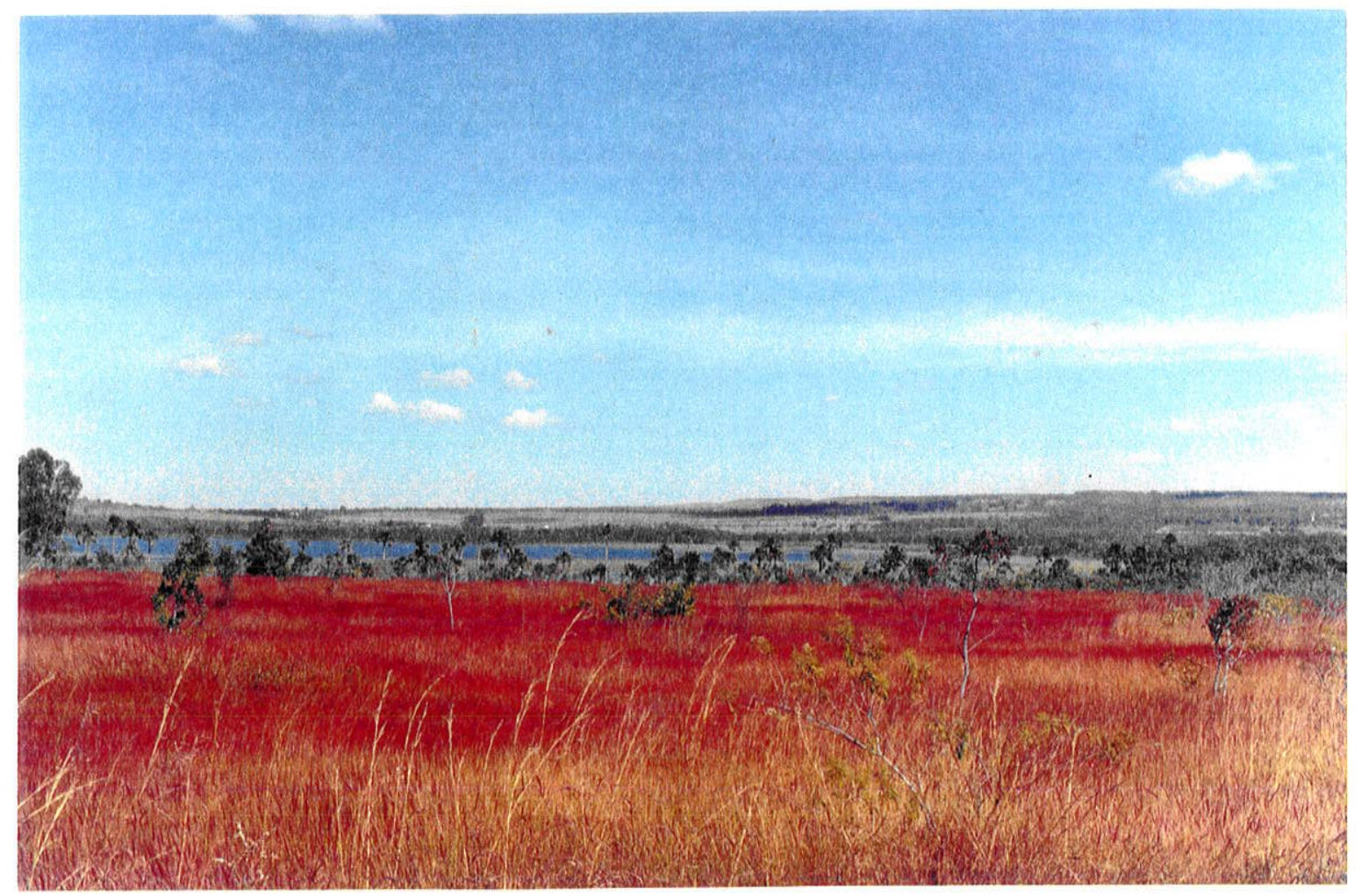

FIGURA 2.1: Vista geral da Lagoa Bonita, Planaltina, DF 


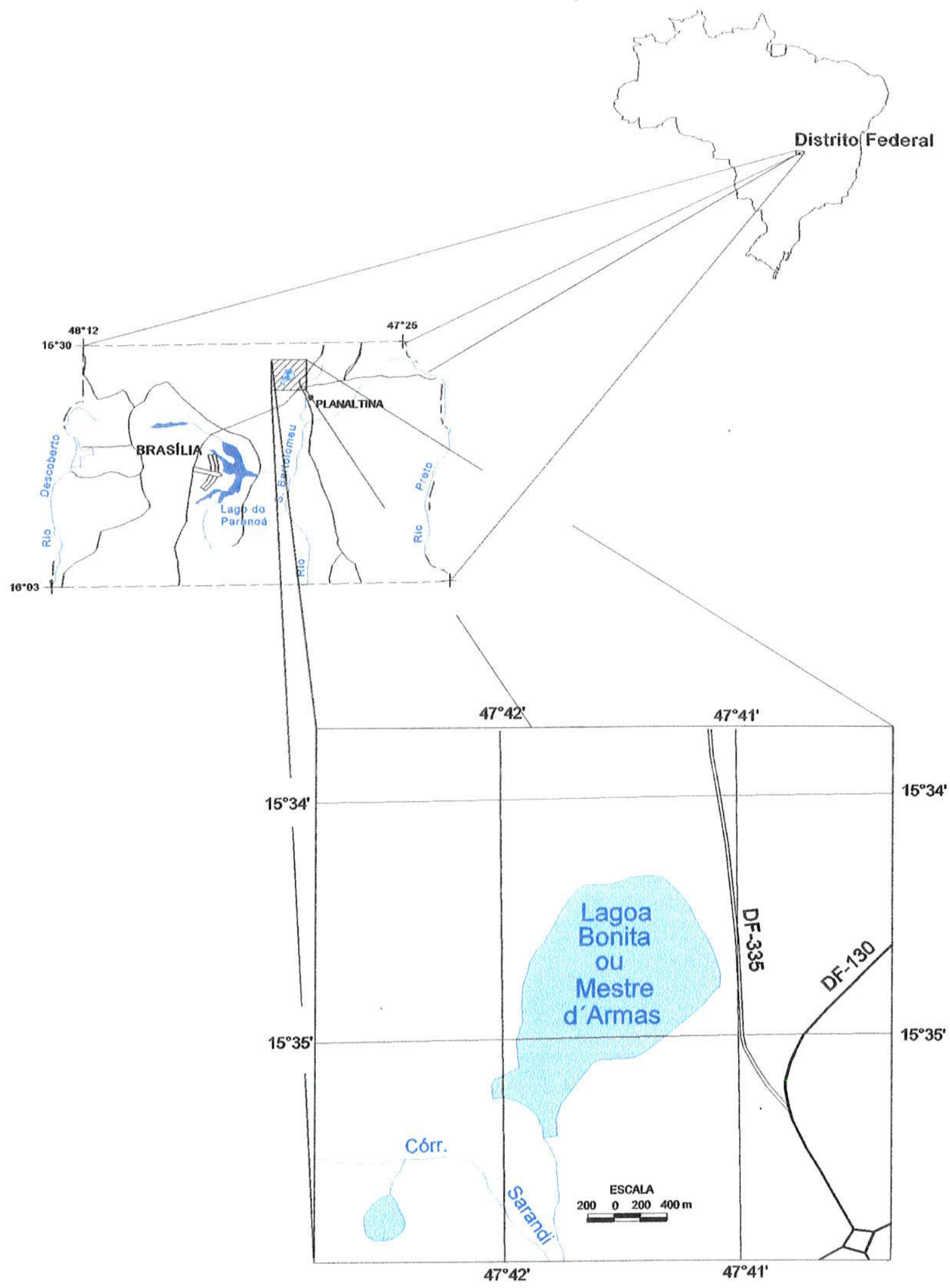

FIGURA 2.2: Localização da área de estudo 
O presente estudo abrange igualmente a área de captação da Lagoa Bonita, cujos limites são definidos pelas cotas elevadas dos interflúvios que a circundam. A área delimitada corresponde a uma faixa com aproximadamente 4 $\mathrm{km}$ de comprimento e largura média de cerca de $3 \mathrm{~km}$, posicionada segundo a direção SW/NE na região do Planalto do Distrito Federal.

\subsection{Hidrografia}

A Lagoa Bonita constitui uma das nascentes do ribeirão Mestre D'Armas que flui para o sul, unindo-se ao ribeirão Pipiripau para formar o rio São Bartolomeu, integrante da bacia do rio Paranaiba. Situa-se em uma área de topografia aplanada em cota próximo a $960 \mathrm{~m}$, constituindo o divisor das bacias hidrográficas do Paraná e do Amazonas (Figura 2.3).

As nascentes dos canais fluviais de primeira ordem, relativas aos córregos Sambaiba e Monjolo, responsáveis pela formação do rio Palmeiras, afluente da margem esquerda do rio Maranhão, integrante da bacia hidrográfica do rio Amazonas, situam-se respectivamente à cerca de $2 \mathrm{~km}$ a noroeste e $5 \mathrm{~km}$ a nordeste da Lagoa Bonita junto à cota de $1.000 \mathrm{~m}$.

Regionalmente a rede de drenagem apresenta um padrão retilineo, com baixa sinuosidade, o que indica um condicionamento ao relevo e aos parâmetros geológicos como litologias e estruturas do substrato. Os canais fluviais são estreitos e pouco profundos, com desniveis médios baixos, em função das características do relevo, o que resulta em uma carga sedimentar insignificante no leito.

Segundo Mamede (1999), a instalaçäo da drenagem das chapadas do Distrito Federal, está associada a processos hidrológicos subsuperficiais. $O$ desenvolvimento de processos hipodérmicos propiciou a liberaçäo do aqüifero, e a fuga de materiais pelo sistema de falhas e fraturas, causando subsidência da superficie e a formação de depressōes rasas. As depressões facilitaram a convergência das águas superficiais, concentrando o escoamento superficial e definindo os leitos. 


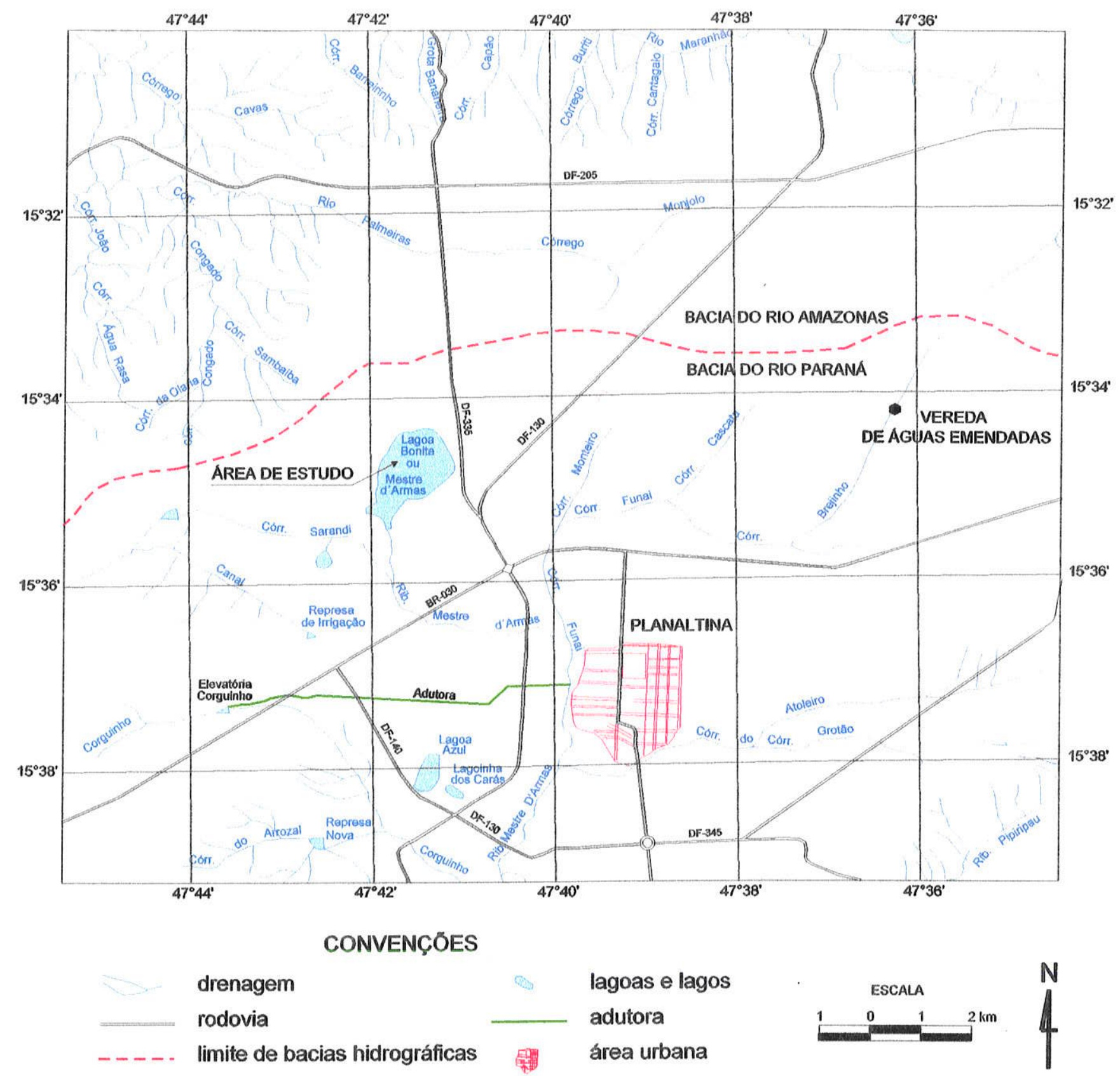

FIGURA 2.3: Rede de drenagem e indicação da área que corresponde ao divisor das bacias hidrográficas dos rios Amazonas e Paraná 
A drenagem instalou-se em uma superficie aplanada cuja idade relativa está relacionada, segundo Vasconcelos (1996) e Mamede (1995, 1999) ao Paleógeno, a partir de quando começaram a se esboçar os primeiros drenos com um traçado vinculado às estruturas tectônicas. Durante o Pleistoceno, fenômenos climáticos e movimentos relacionados à neotectônica diagnosticados por Mamede \& Pereira (1995) e Mamede (1999) nas chapadas do Distrito Federal, provocaram uma reestruturaçăo da drenagem.

As depressões rasas que ocorrem na Resenva Ecológica do IBGE (DF) a sudoeste da área de estudo, foram interpretadas por Mamede (1999) como áreas de subsidência das camadas superficiais devido à dissolução de oxidróxidos de ferro e aluminio e a fuga de material fino em profundidade. Quando as depressões ocorrem em alinhamentos estruturais, favorecem a coalescência das áreas rebaixadas $\theta$ a presença do lençol freático em superficie, dando origem a lagoas e veredas. A Lagoa Bonita, que ocupa uma depressão rasa e originalmente estava associada a uma vereda, deve ter a mesma origem.

A lagoa apresenta atualmente a forma elíptica com eixo maior da ordem de $2.100 \mathrm{~m}$, orientado segundo a direção N/NE e eixo menor de cerca de $1.300 \mathrm{~m}$, orientado na direção NW. Estas dimensōes provavelmente não representam a forma original da lagoa, tendo em vista que a mesma foi barrada na porçăo sul junto à saida para o córrego Mestre D'Armas.

\subsection{Goologia}

\subsubsection{Goologia Regional}

A área do Distrito Federal situa-se na regiäo central da Faixa de Dobramentos Brasilia, uma unidade geotectônica inserida na Plataforma SulAmericana, a qual em conjunto com a Plataforma da Patagônia e a Cordilheira dos Andes constituem as três grandes regiöes tectônicas definidas por Almeida (1967) para o Continente Sul Americano.

A evolução da Plataforma Sul-Americana que teve inicio no Arqueano (>2.500 Ma), apresenta uma estruturação em núcleos cratônicos, estabilizados durante o Transamazônico $( \pm 2.000 \mathrm{Ma}$ ), circundados por faixas de dobramentos 
desenvolvidas durante o Ciclo Orogênico Brasiliano (900-450 Ma) (Almeida \& Hasui, 1984), cuja estabilização final se deu no Neoproterozóico-Eopaleozóico (500-450 Ma).

$\mathrm{Na}$ Plataforma Sul-Americana, na porçăo central do Brasil, destaca-se o Cráton do São Francisco (Almeida, 1977) margeado por faixas dobradas, que foram estruturadas com a inversão tectônica das bacias marginais mesoneoproterozóicas durante o Ciclo Orogênico Brasiliano. A Faixa de Dobramentos Brasilia posiciona-se a oeste do Cráton do São Francisco e a leste do Maciço Mediano Goiano.

As relaçōes estruturais da Faixa Brasilia com o Maciço Mediano Goiano e a Faixa de Dobramentos Paraguai-Araguaia, levaram Almeida et al. (1977) a englobá-las em uma única provincia estrutural denominada de Provincia Estrutural do Tocantins. A Faixa Brasilia representa uma unidade geotectônica posicionada sobre um embasamento de terrenos granito-greenstone-gnáissico, entre a borda oeste do Cráton do São Francisco e a borda leste do Maciço de Goiás (Freitas-Silva \& Campos, 1998).

Segundo Fuck et al. (1993) a estruturaçăo da faixa Brasília pode ser relacionada à evolução de um único evento termotectônico denominado Ciclo Brasiliano, marcado por uma tectônica compressiva responsável pelo desenvolvimento de dobras apertadas nas porçōes internas da faixa e de dobras gradualmente mais abertas nas regiōes mais externas, associadas a falhamentos inversos e empurrões, constituindo um conjunto de estruturas com vergência para leste rumo ao Cráton do São Francisco.

A história evolutiva da Faixa Brasilia teve inicio por volta de $1.800 \mathrm{Ma}$ no Mesoproterozóico, a partir de um rifteamento crustal, com magmatismo continental e intrusōes que hoje constituem os complexos máfico-ultramáficos do tipo Canabrava e Niquelândia e o inicio da deposição dos Grupos Araí, Natividade e Serra da Mesa. A evolução da faixa durante o Mesoproterozóico é marcada pela deposição dos grupos Paranoá, Canastra e Formação Vazante entre 1.400 e $1.000 \mathrm{Ma}$. O final do Mesoproterozóico é marcado pela oceanização da faixa, individualização de seqüências vulcano-sedimentares e o início da deposição do Grupo Serra da Mesa (Freitas-Silva \& Campos, 1998). 
O Neoproterozóico, por volta de $900 \mathrm{Ma}$, é marcado pelo início da inversão tectônica e a instalação de arcos magmáticos. Segue-se o término da deposição do Grupo Araxá ( $\approx 700 \mathrm{Ma}$ ), a sedimentaçăo do Grupo Bambuí entre 750 e 500 Ma aproximadamente, um plutonismo pós-tectônico de caráter granítico ( $\approx 650$ a $450 \mathrm{Ma}$ ), culminando com a cratonização há aproximadamente $450 \mathrm{Ma}$, que marca o fim do Ciclo Brasiliano.

Nos trabalhos mais recentes, o termo ciclo Brasiliano tem sido utilizado de forma mais ampla, englobando a completa evolução dos cinturões e envolvendo sua história pré-orogênese. Inclui sedimentação com deposição de seqüências terrigenas e carbonatadas em ambientes plataformais, formação de terrenos do tipo arco de itha com magmatismo pré-colisional associado, metamorfismo, deformação e amalgamação de diferentes terrenos às margens continentais, culminando com a colisão de blocos continentais (Fuck, 1994; Lacerda Filho et al.,1999).

A importância da Faixa de Dobramentos Brasilia, no contexto da geologia regional, prende-se ao fato do Distrito Federal estar localizadu na região central da referida faixa e na sua transição entre as porçōes internas e externas, com quatro conjuntos litológicos reconhecidos: os grupos Canastra, Paranoá, Araxá e Bambui (Faria, 1995; Freitas-Silva \& Campos, 1998).

\subsubsection{Goologia Local}

Embora a área do Distrito Federal conte com um mapa geológico em escala 1:100.000 (Faria, 1996 apud Freitas-Silva \& Campos, 1998), cerca de 50\% do mesmo é representado por coberturas de solos residuais ou transportados, dificultando a caracterização da geologia local. Freitas-Silva \& Campos (1998), procurando integrar os dados existentes e sanar os problemas advindos do mapeamento de seqüências superficiais, apresentam um mapa geológico do Distrito Federal sem as coberturas de solos, em escala 1:100.00, utilizado como base neste trabalho (Figura 2.4).

Neste contexto, segundo Freitas-Silva \& Campos (1998), na área da Lagoa Bonita e entorno ocorre uma seqüência metassedimentar relacionada ao Grupo Paranoá, definido como tal por Dardenne (1979), cuja ocorrência se estende 
desde o sul do Distrito Federal, até próximo à confluência dos rios Paranã e Tocantins no Estado de Goiás.

O Grupo Paranoá foi datado por Dardenne (apud Freitas-Silva \& Campos, 1998) em função de suas relaçōes estratigráficas com o Grupo Araí (sotoposto) e - Grupo Bambui (sobreposto) e a partir de estruturas estromatolíticas presentes nas unidades carbonatadas, que indicam idade entre 950 e $1.350 \mathrm{Ma}$ para a sedimentação.

Os sistemas deposicionais atribuidos ao Grupo Paranoá correspondem à condiçōes marinhas de plataforma epicontinental, na qual variaçöes na profundidade da lâmina de água em função de ciclos transgressivos e regressivos, provocaram variaçōes na proporção de materiais arenosos e argilosos nas diversas unidades.

Uma estratigrafia integrada para o Grupo Paranoá foi estabelecida por Faria (1995) na qual as unidades, passiveis de uma correlação regional, são denominadas informalmente por letras-código.

No Distrito Federal o Grupo Paranoá é representado por seis unidades, que incluem seqüências de metassiltitos argilosos, ardósias, metarritmitos arenosos, quartzitos médios, metarritmitos argilosos, além de uma unidade psamo-pelíticacarbonatada (Freitas-Silva \& Campos, 1998).

Localmente, a região da Lagoa Bonita e entorno está inserida na unidade Psamo-Pelitica-Carbonatada - PPC, representada principalmente por metassiltitos laminados. Ocorrem também lentes de calcário e de quartzitos mal selecionados e feldspáticos que são facilmente desagregáveis, de ocorrência restrita em superficie, porém fundamentais como elementos-guia para a caracterização desta unidade.

Sobre os metassiltitos em áreas aplanadas, desenvolveu-se uma cobertura detrito-lateritica formada por processos de laterização, caracterizada por latossolos argilosos a muito argilosos, enriquecidos em ferro, e de origem autóctone. Vasconcelos (1996), trabalhando na Amazônia oriental (Carajás), apresenta dataçőes para episódios climáticos quentes e úmidos, responsáveis pela atuação intensa do intemperismo químico com enriquecimento de materiais precipitados, que deram origem às coberturas lateríticas. 


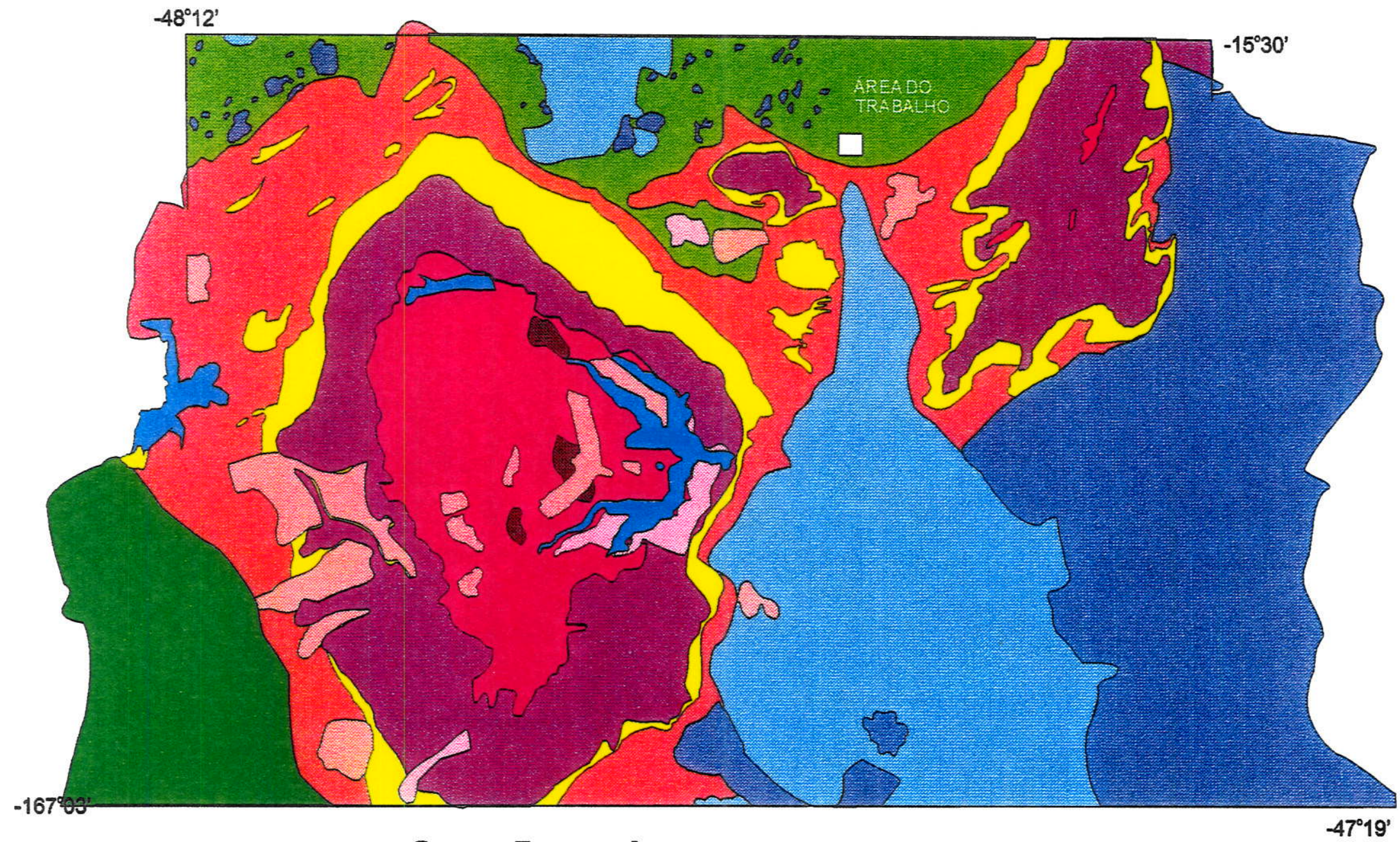

Grupo Bambuí (Neoproterózico)

Grupo Araxá (Neoproterozóico) Grupo Canastra (Mesoproterozóico)

\section{Grupo Paranoá}

(Mesoproterozóico)

Unidade Psamo-Pelítica

Carbonatada - PPC

Metacalcários/Dolomitos

Unidade R4

Metarritmitos sito-argilosos

\section{Unidade Q3}

Quartzito
Unidade R3

Metarritmitos arenosos

Unidade A

Ardósias

Unidade S

Siltitos

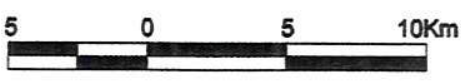

FIGURA 2.4: Mapa geológico simplificado do Distrito Federal (Fonte: Freitas-Silva \& Campos, 1998) 
Estes periodos datados e evidenciados pela recristalização de óxidos de manganês, estariam situados, segundo Vasconcelos (1996), ao final do Cretáceo e no decorrer do Terciário, que inclui dois períodos durante o Eoceno, um no inferior e outro no superior e outra fase úmida que se iniciou ao final do Oligoceno superior e se prolongou até o Mioceno inferior a médio.

Os depósitos mais recentes, relacionados ao Quaternário, são representados por elúvios, colúvios e sedimentos fluvio-lacustres, arenosos a areno-argilosos, que preenchem as zonas rebaixadas por neotectônica, evidenciadas por Mamede (1999) nas chapadas do Distrito Federal, ou depressōes associadas aos processos hipodérmicos, atuantes durante os ciclos de aplanamento geomorfológico.

A alternância de fases úmidas e secas durante o Pleistoceno, relacionadas aos periodos glaciais e interglaciais, propiciou o desenvolvimento de processos de intemperismo quimico, intercalados com processos de pedimentação, com predominância de erosão mecânica, que denudaram as rochas em ambiente morfoclimático quente e seco.

Os depósitos relativos a estes eventos, que propiciaram o remanejamento do material resultante da alteração dos metassiltitos do Grupo Paranoá, foram espraiados nas partes rebaixadas. $O$ volume de material remanejado sofreu ainda a interferência da densidade da cobertura vegetal, que respondia às modificaçōes climáticas (Barberi, 1994). Entretanto, a baixa declividade das encostas nas bacias de captação, como no caso da Lagoa Bonita, não favoreceu a acumulação de sequiências espessas, ou com grande expressão regional.

\subsection{Geomorfologia}

A área de estudo localiza-se no Planalto Central Goiano, uma extensa região com compartimentos escalonados, que compreende o Distrito Federal e o Estado de Goiás. Abrange a faixa de metamorfitos do sistema de dobramentos Brasilia constituída de litologias variadas, estruturalmente complexas, dobradas e falhadas que condicionaram a erosão diferencial. Posteriormente, as modificaçōes paleoclimáticas, ocorridas durante o Paleógeno, Neógeno e Quaternário, atuaram neste planalto mascarando os niveis de aplanamento (Mamede, 1999). 
Esta evolução geomorfológica culminou com o desenvolvimento de diferentes morfologias que permitiram a caracterização de quatro grandes unidades geomorfológicas no Planalto Central Goiano definidas como: Planalto do Distrito Federal, Planalto do Alto-Tocantins-Paranaíba, Planalto Rebaixado de Goiânia e Depressões Intermontanas.

A área de estudo insere-se na grande unidade geomorfológica do Planalto do Distrito Federal, que compreende um grande planalto subcompartimentado em niveis topográficos distintos, com características próprias, porém ligados por traços genéticos comuns (Figura 2.5).

O planalto atua como um centro dispersor da drenagem das bacias hidrográficas do Paraná e Tocantins, onde a configuração da drenagem é fortemente condicionada por falhas (Mamede, 1993; 1999).

O Planalto do Distrito Federal constitui um relevo resultante da exumação de estruturas dobradas no decorrer do Ciclo Brasiliano, onde se destacam dois niveis de erosão bem marcados: um mais elevado com cotas em torno de 1.200 a $1.400 \mathrm{~m}$ do Terciário inferior, denominado Pediplano da Chapada de Contagem e outro com cotas entre 950 a $1.200 \mathrm{~m}$ denominado Pediplano de Brasilia, relacionado ao Eoceno-Oligoceno onde se insere a Lagoa Bonita (Mamede, 1999; Mamede et al., 1983). Os dois níveis de erosão articulam-se entre si através de escarpas, coalescendo em alguns pontos, como na área ao norte da lagoa.

O Pediplano de Brasilia corresponde, segundo Mauro et al. (1982), a uma superficie de aplanamento retocada e inumada, elaborada durante sucessivas fases de retomada de erosão, sem perder suas características de aplanamento.

Os modelados de dissecação resultantes da incisão fluvial, estão representados por interflúvios tabulares, lombadas e colinas com vertentes retilíneas e convexo-côncavas, inclinadas para o eixo principal da drenagem. Geralmente estão recobertas por uma cobertura detritica com mais de $1 \mathrm{~m}$ de espessura, indicando remanejamentos sucessivos, ou com couraça exposta, devido à ablação do material fino que as recobriam.

Nas superficies planas de declives suaves de $2^{\circ}$ a $5^{\circ}$, a intensidade da morfodinâmica é fraca, o que resulta em fraco remanejamento de material que se dá por escoamento superficial difuso (Mauro et al., 1982; Mamede, 1993). 


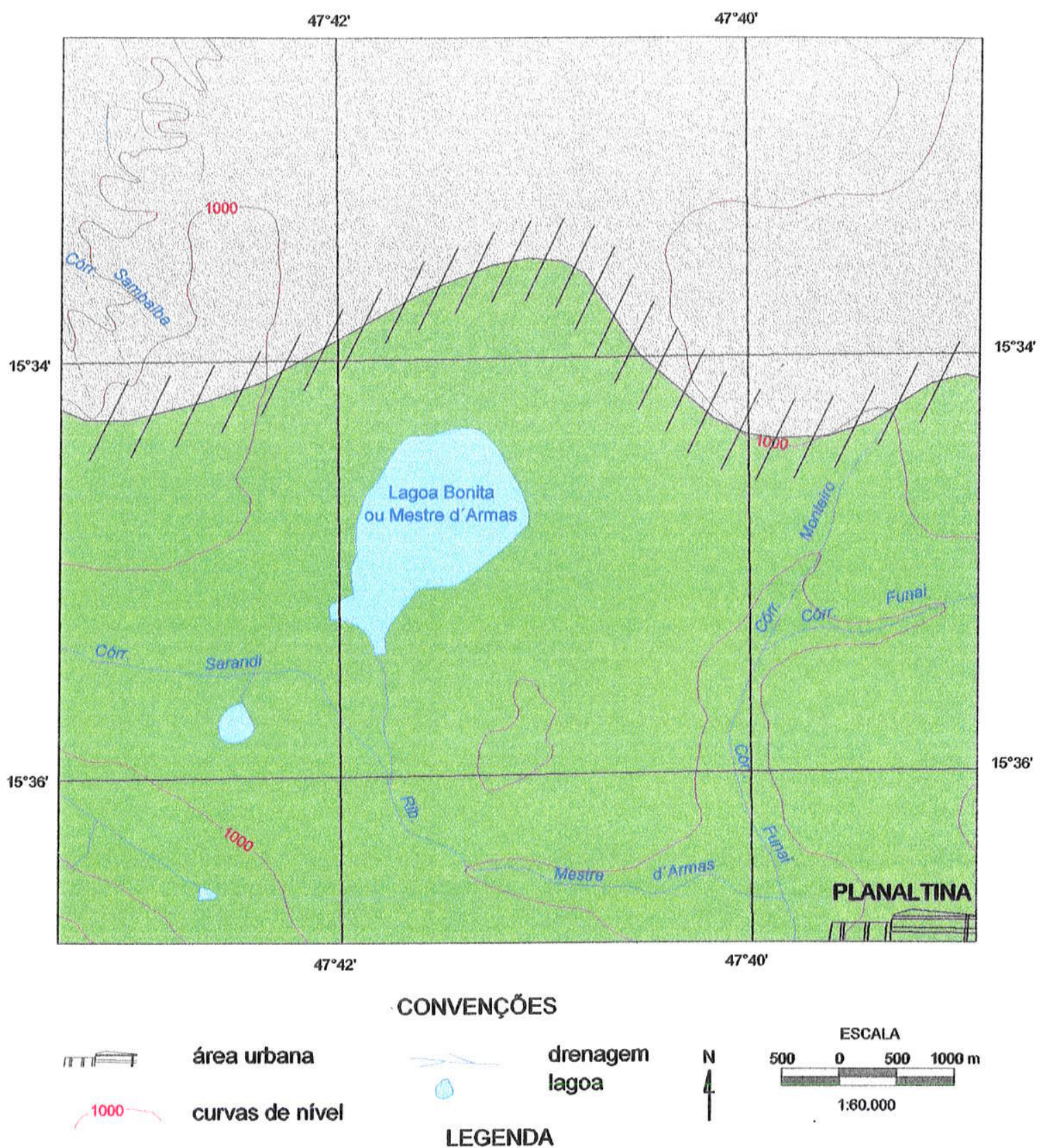

$/ / /$ ZONA DE TRANSIÇÃO ENTRE OS DOIS NIVEIS DE EROSĀO

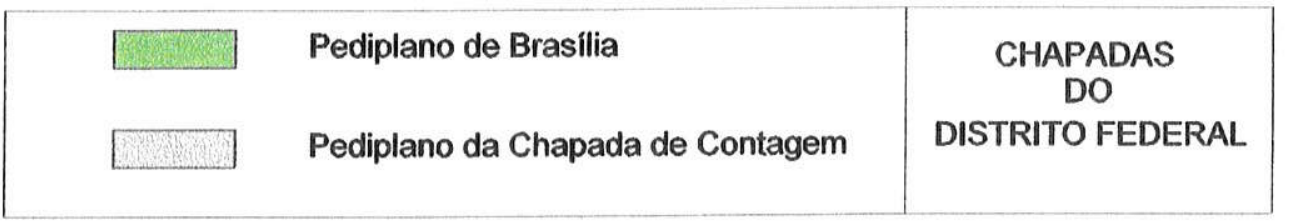

FIGURA 2.5: Mapa Geomorfológico

(Fontes: Mauro et al., 1982; Mamede, 1999)

Organizaçăo: Maira Barberi 


\subsection{Solos}

Na região do Planalto do Distrito Federal, onde se localiza a Lagoa Bonita, desenvolveram-se latossolos (Krejci et al., 1982; SEMATEC, 1996) (Figura 2.6). Condicionados pelo clima tropical sub-úmido com duas estaçōes e associados ao relevo aplanado que possibilita a infiltração e percolação da água superficial e a movimentação do lençol freático durante a estação seca, os latossolos representam os solos em estado mais avançado de intemperismo, sendo caracterizados pela grande profundidade e condiçöes de boa drenagem (Haridasan, 1994).

$\mathrm{Na}$ regiäo predominam quartzitos e metassiltitos e condições de boa drenagem estão presentes, mesmo quando nos solos predomina a fração argila que não interfere na capacidade de retenção e infiltraçăo de água. Isto se deve ao tipo de argilomineral presente (caolinita), ao alto grau de floculação e ao fato da fração argila ser composta predominantemente por óxidos de ferro e aluminio (Haridasan, 1994).

As condiçōes fisico-quimicas para o desenvolvimento dos latossolos propiciam grande acumulação de óxidos de ferro e aluminio, sendo fortemente ácidos e com baixos teores de bases $(\mathrm{Ca}, \mathrm{Mg}$ e $\mathrm{K}$ ) e fósforo disponivel para as plantas. Além disso, apresentam niveis de aluminio disponivel e saturação de aluminio trocável da ordem de até $60 \%$ e recebem a denominação de distróficos. Estas caracteristicas tornam estes solos altamente suscetíveis à erosão, especialmente quando os sulcos de ravinamento atingem áreas onde o subsolo encontra-se pouco coerente.

$\mathrm{Na}$ área da Lagoa Bonita predominam os Latossolos Vermelho-Escuros distróficos, que se desenvolveram sobre chapadas com declividade menor que $8 \%$ em rochas metassedimentares do Pré-Cambriano, eventualmente apresentando uma crosta laterítica cenozóica.

Localmente, margeando a lagoa compreendendo uma faixa com largura entre 100 e $500 \mathrm{~m}$, ocorrem Latossolos Vermelho-Amarelos distróficos (Figura 2.6). Solos hidromórficos também ocorrem de forma restrita, margeando a lagoa na sua porção norte, em uma faixa com aproximadamente 300 a $500 \mathrm{~m}$ de largura e na porção sul/sudoeste. 


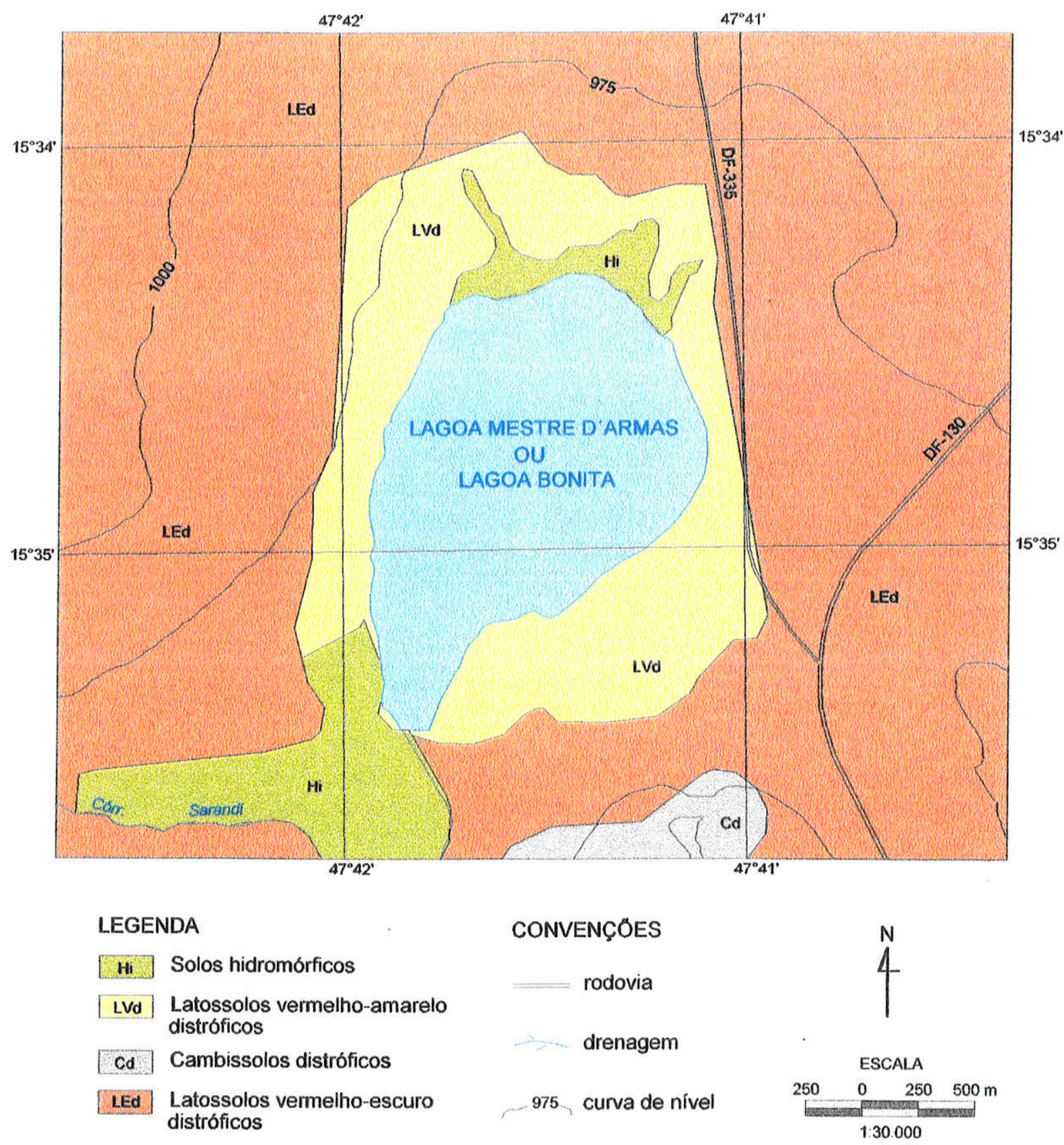

FIGURA 2.6: Mapa Pedológico

(Fonte: SEMATEC, 1996) 
Condicionados pelo relevo e pela drenagem, os solos hidromórficos são caracterizados pela presença do lençol freático raso na superficie ou próximo à superficie durante a maior parte do ano, desenvolvendo-se sob condições de excesso de umidade.

São classificados como Gleis ou Solos Orgânicos de acordo com o teor de matéria orgânica e situam-se normalmente nas depressōes rasas, nas cabeceiras de drenagem e nas áreas de exsudaçăo do lençol freático (Mamede, 1999). Apresentam textura argilosa a muito argilosa, e uma camada de gleização abaixo da camada superficial, geralmente acinzentada devido à redução do ferro, à acumulação da matéria orgânica e à decomposição aeróbia.

\subsection{Clima}

O clima na região Centro-Oeste está diretamente relacionado à dinâmica da circulação atmosférica, que atua no sentido de criar uma uniformidade climática regional. As latitudes entre $15^{\circ}$ e $16^{\circ} \mathrm{S}$ asseguram temperaturas elevadas durante praticamente todo $o$ ano. As diferenças de cotas entre as vastas superficies rebaixadas de cerca de $200 \mathrm{~m}$ e as extensas chapadas de $600 \mathrm{~m}$ a $1.100 \mathrm{~m}$, promovem a diversificação térmica (Nimer, 1989).

A circulação das massas de ar determinantes do clima, é marcada na região pela presença dos ventos alísios de $\mathrm{NE}$ e $E$, provenientes do anticlone tropical do Atlântico Sul (TA), que são quentes e secos; a Massa Equatorial Continental (EC) que flui de oeste e é quente e úmida e a Frente Polar Atlântica (FPA) fria e úmida, proveniente do sul (Figura 2.7).

O período de março até outubro que corresponde regionalmente ao outono, inverno e parte da primavera, é marcado pelo domínio da TA que assegura à região estabilidade climática, condições de baixissima pluviosidade e temperaturas médias altas da ordem de $20^{\circ} \mathrm{C}$, além de céu claro e ensolarado. Durante esta fase, algumas incursōes da FPA interferem na estabilidade climática, ocasionando chuvas frontais de baixa intensidade e breve duração, seguidas por queda de temperatura e aumento de umidade.

No final do inverno e início da primavera, com a redução dos avanços da FPA, os ventos do anticlone tropical (TA) voltam a atuar na região, elevando a 
temperatura e a secura entre os meses de agosto e setembro, quando a umidade atmosférica atinge os valores minimos, da ordem de $20 \%$ de umidade relativa do ar, com condiçōes semelhantes às de regiōes desérticas.

Ao final da primavera e inicio do verão, com o aquecimento progressivo do continente e o deslocamento do sistema do anticione tropical do Atlântico Sul para leste, ocorre a expansão do ar quente e úmido da massa Equatorial Continental (EC) proveniente da região Amazônica.

Este sistema de circulação que é mais atuante durante o periodo de outubro a março, corresponde regionalmente ao verão e é responsável, principalmente a partir de novembro, pela instabilidade climática provocando chuvas fortes, queda de temperatura e na insolação em função da alta nebulosidade (Pereira \& Freitas, 1982). Os curtos periodos de estiagem registrados durante o verão resultam de incursões esporádicas dos fluxos secos da TA.

Em relação à precipitação, a influência orográfica é marcante. A presença das escarpas do Espinhaço e Diamantina a leste impede a penetraçāo dos ventos úmidos provenientes do litoral, acentuando os efeitos da continentalidade $e$ deixando a região na dependência exclusiva das chuvas de verão relacionadas ao fluxo convectivo da EC (Nimer, 1989).

O clima da regiâo do Distrito Federal pode ser definido como quente e semi-úmido com 4 a 5 meses secos. $O$ periodo seco estende-se de maio a setembro, quando a pluviosidade média é inferior a $60 \mathrm{~mm}$ mensais. A estação chuvosa prolonga-se de novembro a março com totais mensais acima de 180 $\mathrm{mm}$, perfazendo totais anuais de precipitação entre 1.200 e $1.700 \mathrm{~mm}$.

Esta distribuição desigual caracteriza um regime de chuva tropical com duas estações, com precipitações máximas no verão, concentradas no trimestre dezembro-janeiro-fevereiro e as minimas no inverno no meses de agosto e setembro (Dambrós et al.,1981; Pereira \& Freitas, 1982) (Figura 2.7).

As temperaturas, determinadas pela influência dos sistemas atmosféricos, da posição geográfica e das formas de relevo, apresentam médias anuais elevadas entre $20^{\circ}$ e $25^{\circ} \mathrm{C}$, com pequenas oscilaçōes registradas nas áreas de topografias mais elevadas. 


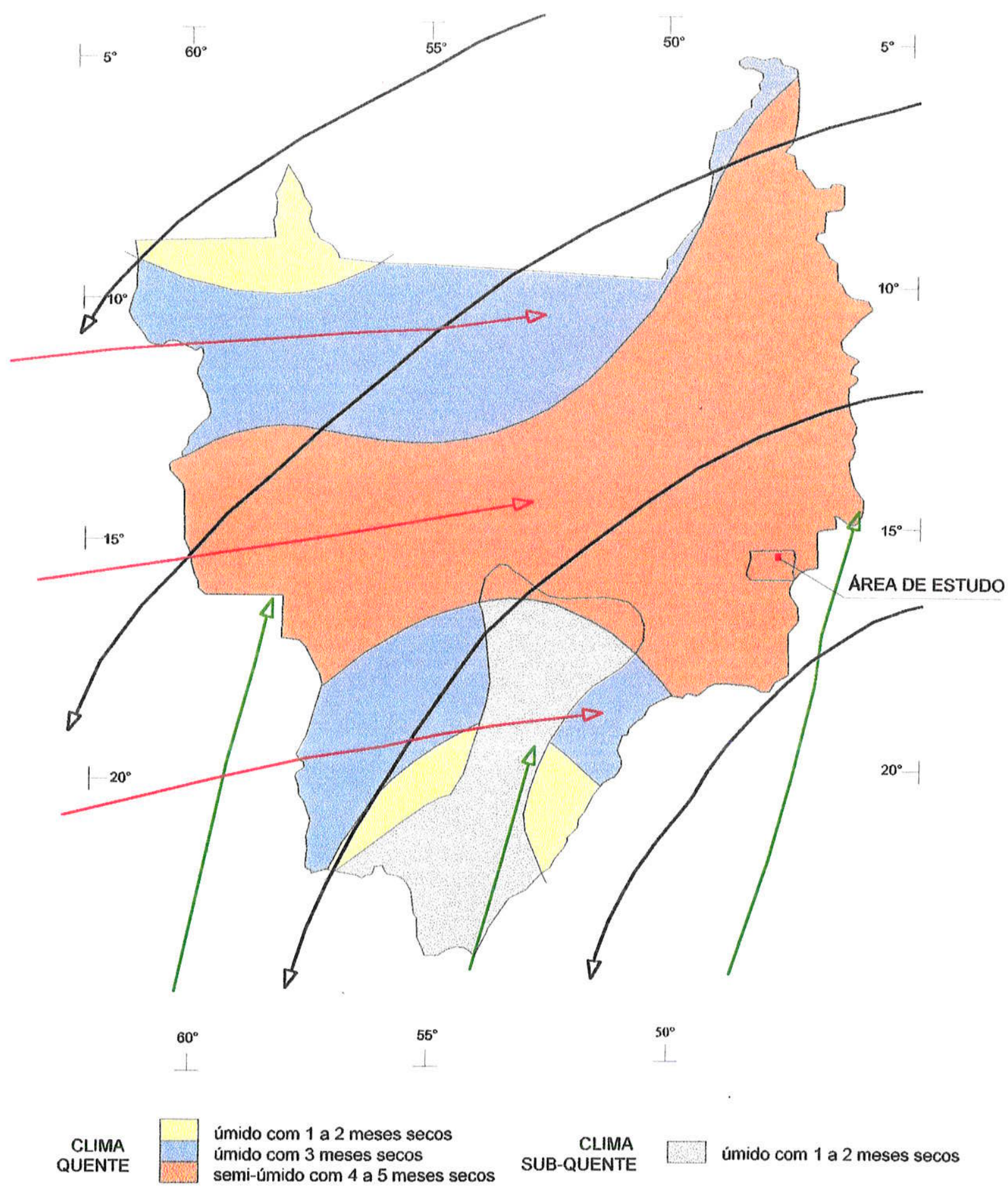

- $\quad 180 \quad 360 \mathrm{~km}$

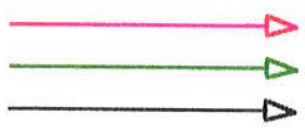

Massa Equatorial Continental (EC)

Frente Polar Atlântica (FPA)

Anticiclone Tropical do Atlântico Sul (TA)

FIGURA 2.7: Sistemas de circulação atmosférica e diferenciações climáticas considerando em conjunto os regimes térmico e pluviométrico (Fontes: Pereira \& Freitas, 1982; Nimer, 1989) Org. Maira Barberi 
No inverno as temperaturas médias anuais são relativamente altas, entre $18^{\circ}$ e $20^{\circ} \mathrm{C}$, em funçăo da continentalidade da área. As minimas absolutas atingem valores inferiores a $8^{\circ} \mathrm{C}$, durante poucos dias no decorrer dos meses de junho e julho, relacionadas à invasăo da FPA, apresentando um aumento gradativo de sul para norte influenciado pela latitude e queda localmente acentuada em funçăo da altitude.

Segundo Fonzar (1978) o Planalto do Distrito Federal e as áreas próximas rumo a norte nordeste, situam-se entre as isotermas de valores absolutos minimos de $2^{\circ}$ a $4^{\circ} \mathrm{C}$, em função da altitude, que alcança $1.100 \mathrm{~m}$ na regiäo da Lagoa Bonita, e $1.700 \mathrm{~m}$ na Chapada dos Veadeiros a norte nordeste do Distrito Federal. Na primavera registram-se os valores máximos de temperatura absoluta, que estão entre $36^{\circ}$ e $42^{\circ} \mathrm{C}$, mesmo em áreas topograficamente elevadas. A ausência de chuvas acentua o caráter megatérmico, sendo setembro e outubro os meses mais quentes do ano.

O balanço hidrico contabiliza a água no solo, a fim de definir a disponibilidade hidrica para as comunidades vegetais. Representa a relação entre a precipitação fornecedora de água e a evapotranspiração que indica teoricamente a quantidade de água que deixaria o solo.

Segundo Thornthwaite (1948, apud Pereira \& Freitas, 1982) o excedente hidrico representa a quantidade de água precipitada que, por não ser absorvida pelo solo, nem evapotranspirada é incorporada à rede de drenagem. A deficiência hídrica está relacionada à quantidade de água que falta ao solo durante o período seco, que limita o desenvolvimento normal da vegetação.

O balanço hídrico atual na região do Distrito Federal, indica a disponibilidade hidrica para a vegetaçăo em cerca de 8 meses do ano. No início do ano, há um excedente hídrico da ordem de $432 \mathrm{~mm}$. A fase de deficiência inicia-se em maio e prolonga-se até o meio de junho, a partir de quando é registrado o déficit que se estende até setembro, perfazendo um déficit total de $370 \mathrm{~mm}$. Em outubro, a quantidade de chuva é suficiente para repor toda a água necessária ao solo, atingindo um excedente hídrico da ordem de $213 \mathrm{~mm}$ a partir da precipitação que ocorre em novembro e dezembro. 
Atualmente, como fator importante na distribuição da vegetação, o clima na área de estudo é do tipo quente e semi-úmido, com média pluviométrica anual oscilando entre 800 a $1.500 \mathrm{~mm}$, excedente hídrico de 100 a $800 \mathrm{~mm}$ durante 4 a 6 meses e deficiência hídrica de 100 e $500 \mathrm{~mm}$ durante 3 a 6 meses.

\subsection{Vegetação}

\subsubsection{O Bioma Corrado}

O bioma Cerrado ocupa $25 \%$ da área do Brasil, com uma extensão de cerca de 1,5 milhão de $\mathrm{km}^{2}$, posicionado entre $3^{\circ}$ e $24^{\circ}$ de latitude sul e $41^{\circ}$ e $63^{\circ}$ de longitude oeste. Esta posição geográfica, na porção central do continente sulamericano, favorece o contato com outros grandes biomas nacionais e engloba na sua porção central, no Planalto do Distrito Federal e proximidades, o divisor de águas das grandes bacias hidrográficas brasileiras: a do Amazonas, Paraná e São Francisco, constituindo um importante corredor ecológico (Figura 2.8).

Os cerrados encontram-se distribuídos em regiōes de planaltos e áreas rebaixadas com predominância de cotas altimétricas que variam entre 300 a $900 \mathrm{~m}$. As maiores altitudes compreendem $5,5 \%$ da área total e são registradas na Chapada dos Veadeiros (1.676 m) a nordeste do Distrito Federal e na Serra do Espinhaço (MG) (1.797 e $2.070 \mathrm{~m}$ ) (Adámoli et al., 1987; DIAS, 1992).

Segundo Ratter (1991) cerca de $50 \%$ da cobertura vegetal nativa foi destruída, principalmente pela instalação de grandes projetos agropecuários que aproveitam não a qualidade do solo, que é tóxico devido à saturação em aluminio, mas principalmente a topografia plana, característica de áreas com cobertura de cerrado. A cobertura vegetal, protegida na forma de unidades de conservaçāo, compreende menos de $5 \%$ da área total, onde se inclui a Estação Ecológica de Águas Emendadas.

As regiōes com ocorrência do bioma Cerrado caracterizam-se por apresentarem um clima com duas estaçōes bem definidas em que a estação seca tem duração de 4 a 6 meses e precipitação média anual varia entre 1.300 e 1.800 mm. Distribui-se principalmente pela região Centro-Oeste, com enclaves nas regiöes norte, nordeste e sudeste (Adámoli et al., 1987; Dias, 1992). 


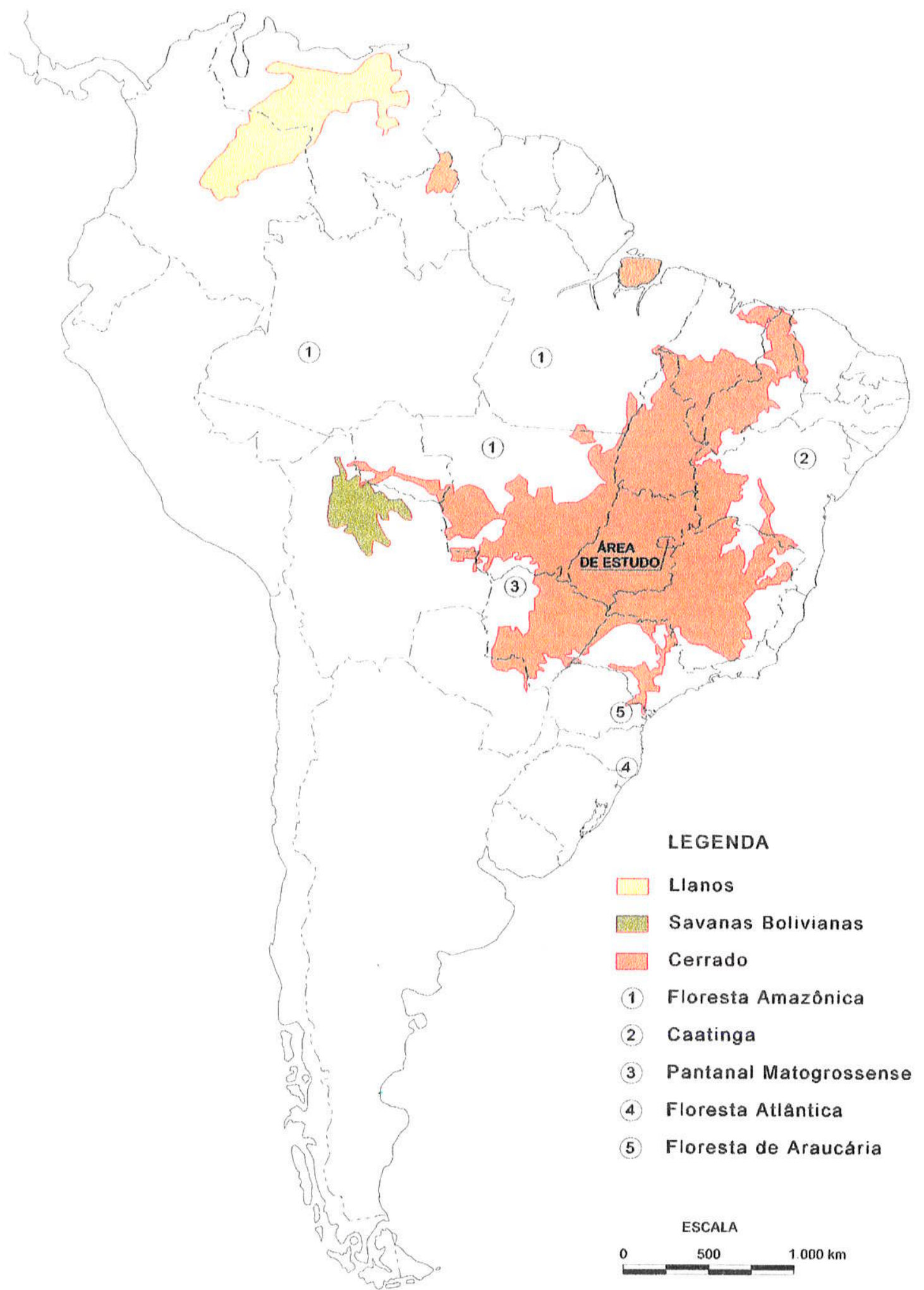

FIGURA 2.8: Distribuição do bioma Cerrado

(Fontes: Ribeiro \& Walter, 1998; WWF, 2000)

Organização: Maira Barberi 
As interações do Cerrado com outros tipos de bioma têm sido abordadas por diversos autores, a partir da ocorrência e distribuição de espécies consideradas típicas dos cerrados como Byrsonima verbascifolia Rich. (Malpighiaceae), Andira humilis Mart. (Leguminosae), e Curatella americana L. (Dilleniaceae) (Giulietti \& Forero, 1990).

A interação com a região amazônica é apontada por (Rizzini, 1979) que relaciona também espécies afins com a região do Pantanal (Adámoli, 1981) e com os Llanos da Venezuela e Colômbia (Daly \& Prance, 1989).

Segundo Pires (1984), várias espécies da Amazônia penetraram no Cerrado através das florestas de galeria, atingindo a Floresta Atlântica também pela conexão dos rios, o que ressalta a importância da área de estudo como corredor ecológico.

Quanto aos Llanos da Venezuela e Colômbia, Daly \& Prance (1989) sugerem que as áreas de fiorestas descíduas e savanas, que ocorrem na região amazônica, tenham servido como um corredor para intercâmbio entre estas áreas e o Cerrado do Planalto Central do Brasil, durante as fases secas relacionadas às glaciaçōes do Pleistoceno.

Segundo Martins (apud Ratter, 1991), estima-se que os cerrados tenha uma flora com cerca de 10.000 espécies, das quais 3.000 são endêmicas do Planalto Central Brasileiro, apesar do contato com outros biomas vizinhos (Richardson, 1978).

O bioma Cerrado, por sua diversidade e complexidades floristica e fisionômica, além das diferentes abordagens nos estudos, tem propiciado diversas discussões, que abrangem desde a caracterização e diferenciação das diferentes fitofisionomias, até questões relacionadas à terminologia envolvendo os termos cerrado e savana.

O termo savana tem sido utilizado sob diversos enfoques por engenheiros florestais, agrônomos, biólogos e geógrafos, na tentativa de definir a fisionomia ou algum tipo de vegetação em particular, considerando-se neste último caso, além do aspecto fisiológico, a composição florística e fatores ambientais abióticos.

Se o termo é utilizado como tipo de vegetação, como fazem alguns autores, refere-se a tipos intermediários entre a floresta sempre verde e o deserto em regiões tropicais e subtropicais (Eiten, 1982). No sentido fisionômico, o termo 
savana refere-se a uma vegetação constituída de árvores e/ou arbustos ou palmeiras acaules, que espalhados formam um estrato bem distinto do rasteiro, 0 qual se apresenta continuo, permanente e constituido predominantemente por gramineas, referindo-se portanto à forma da vegetação (Eiten, 1986; 1987).

Se o termo savana fosse utilizado na América do Sul com o mesmo sentido que é empregado na África, estariam incluídos nele, os cerrados, todos os tipos de mata seca, os campos úmidos, todas as formas de caatinga do Nordeste, além dos Llanos da Venezuela e Colômbia, Gran Sabana da Venezuela, as savanas da Guiana, gran Pajorall do Peru e as savanas do Amazonas, Roraima, Amapá, Ilha do Marajó e Paraná (Sarmiento, 1983; Eiten, 1987).

A partir da comparação das savanas africanas e australianas com os cerrados do Planalto Central Brasileiro, Adámoli et al. (1987) constataram diferenças básicas quanto aos clima e solos. $O$ clima estacional dos cerrados do Brasil Central, caracteriza-se por valores maiores de precipitação média anual. Os solos, normalmente desenvolvidos sobre superficies de pediplanos, são de baixa fertilidade, ácidos, com altos teores de aluminio, profundos e bem drenados.

Segundo Dias (1992), estas características de solos desenvolvidos em superficies aplanadas permitem a retenção temporária das águas das chuvas que, após se infiltrarem, são liberadas lentamente durante os meses secos para as nascentes, possibilitando a perenização dos rios e a manutenção da vegetação durante a longa estação seca.

A partir destas diferenças também constatadas por Eiten (1982), Dias (1992) sugere que as savanas da África e da Austrália constituam biomas relacionados predominantemente ao clima, enquanto as savanas da América do Sul, denominados cerrados, apresentem um controle principalmente edáfico.

Embora os solos aparentemente exerçam um controle importante sobre os cerrados, dados fornecidos pelo IBGE (1990) mostram que a geologia da região dos cerrados é bastante complexa e diversificada, com predomínio de rochas do Pré-Cambriano com coberturas detrito-lateríticas cenozóicas, mas incluindo também planaltos areníticos e basálticos paleozóicos das bacias sedimentares do Paraná e Parnaíba, além de depósitos mesozóicos das bacias sedimentares do São Francisco e Parecis e as bacias sedimentares cenozóicas do Paraguai, Araguaia e Guaporé. 
Trabalhos posteriores procuraram estabelecer não só os elementos abióticos relacionados com o bioma Cerrado, como também o grau de interferência destes elementos. Segundo Eiten (1994), o efeito do clima sobre o Cerrado é indireto e em escala maior através de sua atuação sobre o solo de uma província geográfica onde, atendidas as condições de amplitude térmica com geadas infreqüentes e valores intermediários entre precipitação minima de 750 mm/ano e máxima de $2.000 \mathrm{~mm} / \mathrm{ano}$, propiciaria a ocorrência dos cerrados. A diferenciação das fitofisionomias dos cerrados estaria ligada a diferentes tipos de solos e conseqüentemente aos diferentes tipos que rochas que os geraram.

Além do clima e do solo, outros elementos, como o fogo, também tem sido apontados, como elementos importantes atuantes na configuração da fisionomia da vegetação de um cerrado. Warming (1908) em seu trabalho clássico e pioneiro desenvolvido sobre os cerrados da região de Lagoa Santa (MG), já apontava para a açăo do fogo na queda de folhas, na presença de formaçőes suberosas e na produção de formas contorcidas.

Segundo Ribeiro \& Walter (1998) não existe uma flora homogênea no bioma Cerrado, mas sim um mosaico vegetacional, com floras características para cada área, resultante da interação entre os parâmetros bióticos e abióticos que determinam mudanças qualitativas e quantitativas na composição da vegetação.

Estabelecer os fatores determinantes da rica e variada composiçâo floristica e do aspecto peculiar de suas diferentes fitofisionomias, tem-se constituido no objetivo constante dos trabalhos sobre os cerrados. Entretanto, as relações entre os atributos bióticos e abióticos responsáveis pelas diferentes fitofisionomias deste bioma, podem ser melhor compreendidas por uma abordagem interdisciplinar, onde sobressaem os trabalhos de escala regional desenvolvidos pelo RADAMBRASIL (Assis \& Silva, 1982; Guimaräes, 1982) e pelo Serviço Nacional de Levantamento dos Solos (EMBRAPA, 1983, 1998).

Neste trabalho, em funçäo da objetividade, simplicidade e clareza nas definições dos tipos fisionômicos, a classificação utilizada fundamentou-se nos trabalhos de Ribeiro et al. (1985) e Ribeiro \& Walter (1998), com modificaçzes destinadas a contemplar tipos fisionômicos importantes desta pesquisa, não ressaltados pelos autores. 
Utilizando critérios que incluem a estrutura da vegetação, a composição floristica e aspectos ambientais, foram descritos para o bioma Cerrado 11 tipos fitofisionómicos considerados como formaçōes florestais (Mata Ciliar, Mata de Galeria, Mata Seca e Cerradão), formaçōes savânicas (Cerrado no sentido restrito, Parque de Cerrado e Palmeiral) e formações campestres (Campo Sujo, Campo Rupestre, e Campo Limpo), muitos dos quais com sub-tipos.

Complementando a classificação de Ribeiro \& Walter (1998), foi criada a categoria de formações palustres que inclui o Brejo e a Vereda, esta última anteriormente incluida em formaçōes savânicas.

\subsubsection{História ovolutiva do Corrado}

A história evolutiva dos cerrados e a riqueza da vegetação neotropical, tanto das savanas como das florestas, está intimamente relacionada às histórias geológica e climática pré-pleistocênicas do Continente Sul Americano. Durante o Paleozóico superior até o Jurássico, a América do Sul e a África constituiam parte do Gondwana, apresentando uma mesma província floristica muito diferente de outras partes do mundo, com um clima relativamente seco (Van der Hammen, 1974; 1991; Ratter \& Dargie, 1992).

A fragmentação do Gondwana no Cretáceo provocou uma série de modificações ambientais, em parte devidas às variações no nivel do mar resultantes de movimentos tectono-eustáticos (Haq et al., 1987; Hays \& Pitman, 1973). O aumento dos contrastes sazonais resultantes das mudanças na relação área continental, área oceânica, aliado ao isolamento do Continente Sul Americano e seu posterior deslocamento para latitudes mais baixas, propiciou a instalação de condições ecológicas especificas, provocando uma complexidade de relaçōes entre as floras sul-americanas (Hooghiemstra \& van der Hammen, 1998; van der Hammen \& Hooghiemstra, 2000).

No final do Cretáceo e início do Paleógeno, embora ainda ocorressem claras relações floristicas entre a África e a América do Sul, inicia-se o desenvolvimento da flora neotropical. No Paleoceno diversas familias e gêneros de plantas são reconhecidos, como Bombacaceae e Mauritia e embora as espécies surgissem e desaparecessem no decorrer do tempo, a tendência geral 
era de um contínuo aumento da diversidade e dos táxons que correspondem à tipos recentes (Hooghiemstra \& van der Hammen, 1998; van der Hammen \& Hooghiemstra, 2000).

Desta forma, o desenvolvimento desta flora sul-americana se daria em um continente isolado que se deslocava para latitudes mais baixas e estava sujeito a condições ambientais oscilantes, com a ocorrência de periodos quentes e úmidos, responsáveis pela formação das coberturas lateriticas, durante o Paleógeno e o modelamento do relevo, através de processos de pediplanação nas fases mais secas (Vasconcelos, 1996; Mamede, 1996).

Segundo van der Hammen \& Hooghiemstra (2000), no Eoceno já ocorria uma alta diversidade na floresta tropical, que se desenvolvia sob condiçōes de temperaturas e precipitações mais altas que as atuais, quando já se reconhecem famílias como Malpighiaceae e gêneros como Alchomea e Podocarpus. No Mioceno as Gramineae atingem um desenvolvimento intensivo e há indicações de que a diversidade da flora atingia valores maiores que os atuais (Roshevitz, 1969; Hooghiemstra \& van der Hammen, 1998).

No final do Oligoceno e inicio do Mioceno grande parte da drenagem da Amazônia noroeste se dirigia para norte ao. longo do sistema do Paleo Rio Orinoco, rumo ao delta da região de Maracaibo. No Mioceno médio a subida da cordilheira leste dos Andes provocou mudanças nos sistemas dos rios, desenvolvendo o Rio Amazonas que até então não tinha estabelecido a conexão com o Atlântico e alimentava o sistema do Paleo Rio Orinoco que corria em direção ao Caribe (Hoorn et al., 1995). Águas salobras, entrando na Amazônia a partir do Caribe, do Pacifico e possivelmente do Atlântico durante o Mioceno médio, criaram grandes áreas de mangue.

A subida efetiva dos Andes orientais e da Cordilheira de Mérida no Mioceno superior resultou em mudanças maiores na paleogeografia, afetando a atual área andina até então pertencente às terras baixas. Ocorre uma mudança no curso do Rio Orinoco, o Rjo Amazonas perde a conexāo com o Caribe e voltase para o Atlântico. Com a elevação final dos Andes durante o Plioceno ocorre uma reordenação da drenagem, a definição da bacia amazônica e a formação de uma área com alta pluviosidade na sua porçảo mais ocidental, próxima à região 
andina (van der Hammen, 1991; Hoorn et al., 1995; van der Hammen \& Hooghiemstra, 2000).

Do ponto de vista ecológico, a elevação dos Andes resultou na formação de novos ambientes, na redistribuição dos grupos taxonômicos nas novas áreas e na separaçāo da floresta úmida pacifica da floresta amazônica, provocando um forte endemismo. A criação dos Andes abriu caminho para o desenvolvimento da flora andina pela evolução/especiação a partir da flora tropical das terras baixas $e$ estimulou a invasão de táxons de zonas subtropicais temperadas com elementos de clima frio e de vegetação aberta imigrados do sul e do norte e a entrada de outros taxons tropicais como Bombacaceae, resultando em um aumento da diversidade (van der Hammen \& Hooghiemstra, 2000).

Desta forma, as profundas modificações paleogeográficas e tectônicas ocorridas no Paleógeno e especialmente a partir do Mioceno, geraram freqüentes mudanças ambientais criando diferentes tipos de estresses que poderiam ter levado à extinçōes, mas poderiam também ter contribuido para uma forte evolução e especiação, gerando um balanço positivo entre evolução e extinção, responsável pela alta biodiversidade da flora tropical no Mioceno (van der Hammen \& Hooghiemstra, 2000).

Nas terras baixas tropicais, as regiōes de climas mais secos atualmente presentes ao norte e ao sul da Amazônia, recobertas pelas savanas, savanas arbóreas, florestas semi-desciduas e cerrados, estabilizaram-se gradualmente nas suas posições atuais no decorrer do Mioceno e Plioceno, quando os registros polínicos registram a presença extensiva das Gramineae, Compositae e outras ervas, além da presença eventual de Byrsonima e Curatella (Hooghiemstra \& van der Hammen, 1998).

Mudanças na temperatura começaram a ocorrer durante o Neógeno, com fases mais frias interrompendo um clima mais quente que o atual. Ao final do Plioceno, um forte resfriamento produziu o primeiro período glacial, resultante de uma associação de eventos, onde se sobressaem as influências das variaçōes nos parâmetros orbitais da Terra, conhecido como Teoria de Milankovitch, marcando assim o início do Quaternário (Pisias \& Embrie, 1987; SalgadoLabouriau, 1994, Suguio, 1999). Com o estabelecimento da ligação entre as 
Américas do Sul e Central as condições geológicas e geográficas tornaram-se semelhantes às atuais.

Embora o Pleistoceno no Hemisfério Norte seja caracterizado por uma série de periodos glaciais, as discussões quanto ao número de glaciaçöes tem se prolongado (Martin et al., 1986). Entretanto, a alternância de períodos glaciais e interglaciais em curtos períodos de tempo geológico, mudaram repetidamente e de forma acentuada a face da Terra nas latitudes temperadas do norte, com extinções de animais, especiações e profundas mudanças nas distribuições geográficas de plantas e animais.

No Hemisfério Sul as glaciações que estiveram restritas às altas altitudes, provocaram também diversas alteraçōes que têm sido consideradas correlacionáveis mas diacrônicas às do Hemisfério Norte. No Continente Sul Americano as modificações mais significativas dizem respeito às variações nos niveis do mar e dos lagos andinos, às modificaçōes nas condições morfogenéticas e às mudanças na composição e distribuição da vegetação.

A queda geral da temperatura com a instalação dos ciclos glaciais e o aumento da precipitação relacionada à elevação dos Andes, pode ter estimulado posteriormente a entrada de elementos montanos andinos na flora das terras baixas tropicais, criando novas espécies por adaptaçōes ou modificando o conjunto da vegetação. Segundo van der Hammen \& Hooghiemstra (2000) o impacto da queda da temperatura e posteriormente da precipitação, de forma repetida em todo intervalo glacial do Pleistoceno, deve ter levado à consideráveis extinções ao invés de extensivas especiações, o que parece ser evidenciado pela maior biodiversidade no Mioceno com relação ao Holoceno.

A maior fonte de dados das mudanças climáticas do Pleistoceno, provém da região andina, onde a análise dos sedimentos lacustres situados nas altas planicies de Bogotá, com um registro contínuo dos últimos 3,5 milhões de anos, permitiram a caracterização de uma longa sequuência de periodos glaciais e interglaciais que modificaram o conjunto e a posição das faixas de vegetação da região andina e o limite da floresta andina que se moveu entre 2.000 e $3.500 \mathrm{~m}$ de altitude (Hooghiemstra, 1984).

Entretanto, nas terras baixas tropicais, em função das condições gerais de maior estabilidade, os depósitos com informaçōes paleoecológicas, passiveis de 
evidenciarem as modificaçōes no conjunto e na distribuição da vegetaçăo, estão restritos ao último glacial Würm (Wisconsin) iniciado por volta de 90.000 anos AP.

Esta última glaciação foi dividida na região andina em Glacial inferior (90.000 a 75.000 AP), Pleniglacial (75.000 a 13.000 AP), subdividido em Inferior (75.000 a 60.000 AP), Médio (60.000 a 28.000 AP) e Superior (28.000 a 13.000 AP) e o Glacial Tardio ou fase de degelo (13.000 a 10.000 AP) (van der Hammen, $1974 ; 1991)$. Para o Pleniglacial Superior é definida uma fase denominada Último Máximo Glacial - UMG (Last Glaciation Maximum - LGM) iniciado por volta de 20.000-18.000 anos AP, a partir de quando as modificaçōes nas condiçöes climáticas se tornam muito acentuadas com evidências de quedas na precipitação e na temperatura, afetando toda a regiāo tropical.

Segundo van der Hammen et al. (1992) estas alteraçöes climáticas relacionadas à última glaciação, provocaram na região andina fases de expansão da floresta úmida nos períodos de major umidade ou expansão da vegetaçăo dos páramos nas fases secas. Nas terras baixas costeiras na Guiana e Suriname a distribuição dos grupos ecológicos de vegetaçäo ao longo da costa mostra variaçöes relacionadas à regressão do nivel do mar durante o máximo da glaciação, quando a área costeira era dominada pela vegetação de savanas.

Altas representaçöes de pólen de Podocarpus, llex e Hedyosmum nas terras baixas da Amazónia, durante o último glacial, são usadas também como evidências de modificações climáticas. O deslocamento destes elementos montanos, indicaria condições mais frias que as atuais.

Nas terras baixas tropicais a distribuição dos dois grandes biomas, a floresta úmida amazônica e os cerrados e savana durante a úttima glaciação, têm levado à novas discussões. Segundo van der Hammen \& Hooghiemstra (2000) as fases secas detectadas e relacionadas ao último glacial, promoveram a fragmentação da Floresta Amazônica e a expansão das savanas e cerrados sobre as áreas atualmente recobertas pela floresta úmida, criando desta forma um padrão com núcleos isolados de floresta úmida, formando áreas de refúgios. $O$ conjunto de espécies da floresta úmida das terras baixas tropicais, provavelmente não teria sido muito diferente da atual, porém as proporções relativas seriam diferentes. 
Uma vegetação aberta de campos cerrados, savanas ou cerrados, estaria presente em áreas atualmente recobertas pela floresta úmida, como Katira em Rondônia, na porção sul, sudoeste da Amazônia, na Serra dos Carajás, na Amazônia oriental e na costa da Guiana e do Suriname durante as fases de nivel do mar baixo. $O$ desenvolvimento de campos de dunas na regiăo dos Llanos e do Baixo Rio Negro e Rio Branco na noroeste da Amazônia, constituiriam também evidências da fragmentação da floresta (van der Hammen \& Hooghiemstra, 2000).

Esta hipótese defendida por diversos autores como Haffer e Vanzolini (apud Bigarella, 1994), já havia sido levantada por Ab'Saber (1977), baseado em dados geomorfológicos e por Bigarella (1964, apud Bigarella, 1994), a partir da constatação da presença de manchas de cerrados ilhados na floresta amazônica na região de Rondônia, onde as condições de pluviosidade reinantes atualmente são maiores que as observadas na maior parte das áreas recobertas pelos cerrados.

Mais recentemente a hipótese da fragmentaçăo da floresta foi apoiada por Clapperton (1993) que, a partir de uma revisão dos dados geomorfológicos da América do Sul, propõe modificaçōes ambientais marcantes durante o Último Máximo Glacial (UMG) quando condições frias e secas acentuadas teriam provocado a retração da floresta úmida e a expansão das savanas e cerrados, porém com um padrão de distribuição diferente.

Entretanto, Colinvaux et al. (2000) analisando os diferentes dados existentes para as terras baixas tropicais durante o Pleistoceno e assumindo que as plantas responderam às modificações climáticas como espécies e não como associações ou biomas, postularam que em nenhum momento, durante o Pleistoceno, a floresta úmida tropical foi fragmentada. Os dados de pólen, embora escassos, revelam persistência da vegetação amazônica frente às mudanças climáticas dos ciclos glaciais. As modificações estariam relacionadas às mudanças na composição da floresta pela entrada de elementos montanos, particularmente como resposta a quedas na temperatura (Colinvaux et al., 1996).

Segundo Colinvaux et al. (2000), embora a Amazônia nunca tenha sido árida, foi um pouco mais seca no períodos glaciais, o que explicaria as variações nos niveis dos lagos e teria provocado movimentos nos ecótonos floresta /savana, com perda de floresta nas zonas periféricas, porém em áreas pequenas e 
localizadas. Entretanto, a redução da precipitação nunca foi suficiente para fragmentar a floresta úmida tropical, e o fato da mesma ter permanecido estável desde o início do Pleistoceno contribuiu para o desenvolvimento da alta biodiversidade. As maiores mudanças na comunidade vegetal se dariam a partir do aquecimento global no início do Holoceno que resultaria na expulsão das plantas com intolerância ao calor, da floresta das terras baixas amazônicas.

Nas áreas dos Llanos, recobertas atualmente por savanas, os registros que se iniciam por volta do UMG, mostram uma estabilidade na composição da vegetação com variaçōes resultantes principalmente da extensão dos campos savanas nas fases mais secas durante o UMG e o Glacial tardio. A partir do inicio do Holoceno e no decorrer deste verifica-se uma tendência geral de aumento de umidade que culmina com uma fase mais úmida que o atual por volta de 4.000 anos AP, detectada pelo aumento significativo de pólen de Mauritiella. Elementos colonizadores como Cecropia indicam um aumento do impacto humano sobre a vegetaçăo por volta de 3.850 anos AP.

Os movimentos gerais da vegetação nas áreas do Planalto Central ainda não são possiveis de serem estabelecidos, devido ao pequeno número de sítios analisados até o momento. Entretanto, segundo Salgado-Labouriau (1997), há evidências de que as áreas atualmente recobertas pelos cerrados também responderam às mudanças climáticas pleistocênicas, através de modificaçōes no conjunto da vegetação e ou na distribuição dos diferentes fitofisionomias do bioma cerrado.

A maior parte dos dados de áreas de cerrados alcançam o final do Pleniglacial médio, em cerca de 36.000 anos AP, e mostram flutuações significativas no grau de umidade e na temperatura, permitindo visualizar uma tendência geral. Durante o Pleniglacial Médio e parte do Pleniglacial Superior, os registros palinológicos de diversas áreas apontam para um aumento de umidade e queda na temperatura, evidenciados pelo aumento de elementos arbóreos e a presença de táxons indicativos de frio como llex e Podocarpus. A vegetação seria representada por um mosaico que incluiria o cerrado arbóreo denso, florestas de galeria e em algumas áreas mais ao sul, a presença da mata de Araucária, que atualmente está restrita até a latitude de $24^{\circ} \mathrm{S}$ (Salgado-Labouriau, 1997). 
Entre 22.000 e 18.000 anos AP a temperatura e a umidade começam a decrescer. $O$ registro destas modificaçōes evidencia que as áreas posicionadas nas latitudes mais baixas, foram afetadas primeiro, mostrando uma tendência que levou à retração das matas e à expansão dos campos cerrados, com a rarefação da vegetação em algumas áreas. Esta fase extremamente seca e fria que aparentemente se prolongou durante o Último Máximo Glacial (UMG) é evidenciada em alguns sítios pelo rebaixamento dos niveis dos lagos, pela substituição da sedimentação orgânica por sedimentos silto-arenosos e pelo registro de niveis erosivos que provocaram hiatos na sedimentação.

A fase seca permanece no Planalto Central até o inicio Holoceno, por volta de 7.000 a 8.000 anos AP, a partir de quando a expansão das matas de galerias e a instalação das veredas em muitas áreas, atestam o aumento da temperatura $e$ da umidade, mostrando uma tendência que se consolidou no decorrer do Holoceno. O clima tornou-se provavelmente similar ao atual nas áreas de cerrados com uma estação seca, variando entre 3 a 5 meses, dependendo da região. A vegetação foi provavelmente semelhante a atual formando um mosaico de cerrados cortados por drenagens com florestas de galerias e veredas e manchas de cerrado denso ou cerrado aberto.

Por volta de 4.000 anos AP, o aumento do pólen arbóreo, nas áreas de cerrados, sugere a expansäo e do cerrado denso, indicando uma fase com aumento de umidade até cerca de 1.400 anos AP, a partir de quando se instalam as condiçōes climáticas atuais. $O$ registro do impacto humano sobre a vegetação nos cerrados do Planalto Central só é bem marcado a partir de tempos coloniais e a ação do fogo está bem registrada como elemento natural, desde o Pleniglacial Médio, muito antes da presença do homem nas áreas de cerrados, constatada por volta de 11.00 anos AP (Schmitz et al., 1989).

Atualmente a distribuição dos diferentes tipos de vegetação da zona tropical do Hemisfério Sul é controlada em parte pela precipitação média anual e representada por um mosaico que inclui a floresta tropical úmida na região amazônica, o complexo montano andino, onde a distribuição dos conjuntos vegetacionais é controlada pela altitude e o cerrado ou savana que ocupa parte da Venezuela e Colômbia (Llanos Orientais e Orinoco) e a região central do Brasil. 


\subsubsection{Ocupação do bioma Cerrado no Planalto Central}

A compreensão da ocupação pré-histórica do bioma Cerrado no Planalto Central passa necessariamente por uma análise que envolve a origem do homem americano e os primeiros registros da ocupação do continente sul americano, ao final do Pleistoceno. O modelo clássico proposto por Christy Turner II (1983, apud Dillehay, 1997a) que postula a ocupação do continente americano em épocas recentes após 12.000 anos AP, a partir de três ondas migratórias, oriundas da Sibéria ou do nordeste da Ásia, passando pelo estreito de Bering, tem sido bastante questionado atualmente.

Segundo Dillehay (1997a), a entrada do homem na América tem se constituido em uma questão polêmica, tanto com relação às datas e ao número de ondas migratórias, como também com relação à própria rota. Estudos baseados em diferentes fontes de dados que incluem análises de seqüência de DNA, diferentes aspectos da antropologia fisica, lingüistica e vestigios culturais, têm proposto diferentes tipóteses para estas questões, muitas das quais bastante antagônicas.

Embora o registro fóssil do homem americano seja extremamente escasso, Dillehay (1997a), aponta para uma questão importante relacionada à existência de dois tipos de esqueletos humanos na América do Sul, datados do final do Pleistoceno, início do Holoceno.

Alguns estudos recentes, baseados na diversidade genética e morfológica observada nestes esqueletos (Lahr,1996 apud Salzano,1997) apontam maiores afinidades genéticas e morfológicas dos sul-americanos antigos com as populaçōes do Pacifico sul e sul-asiáticas, do que as esperadas com os norteasiáticos e siberianos. Estes dados, aliados à novas descobertas arqueológicas poderiam levar, segundo Salzano (1997), a reconsiderar a origem e natureza dos primeiros povos que habitaram a América do Sul, considerando para estes uma origem via Pacífico sul.

Entretanto, até o momento, há um consenso geral quanto à entrada do homem na América através do estreito de Bering, permanecendo a discussão quanto ao número de ondas migratórias e as datas, para as quais, as análises genéticas e arqueológicas apontam uma primeira entrada por volta de 30.000 
anos AP. Estes dados säo apoiados por Neves et al. (1997), que a partir da análise de crânios fósseis sul-americanos sugere uma entrada ainda mais antiga, anterior ao estabelecimento da morfologia especializada dos mongolóides, o que explicaria a variabilidade morfológica dos grupos antigos encontrados na América do Sul.

Estas propostas que sugerem uma entrada anterior há 12.000 anos AP mostram-se coerentes com as novas datas aceitas para evidências arqueológicas obtidas na América do Sul, como o sítio Monte Verde na regiāo centro-sul do Chile (Dillehay, 1997b; Meltzer, 1996) datado em cerca de 12.500 anos AP, considerando-se a necessidade de um intervalo de tempo para que as populações vindas através do estreito de Bering alcancem o continente sulamericano.

A ocupação da América do Sul no Pleistoceno tardio foi sintetizada por Barbosa (no prelo), que apresenta uma relação dos sítios arqueológicos com suas datações e caracteristicas, incluindo tanto os sitios cujas datas apresentam-se coerentes com a proposta da entrada do homem na América por volta de 30.000 anos AP ou pouco antes, como aqueles que destoam do contexto regional sulamericano.

No período anterior há 15.000 anos AP, segundo Barbosa (no prelo) o registro da ocupação humana no continente sul-americano é bastante fragmentário, com referências à região de Ayacucho no sul do Peru e a duas áreas no interior do Brasil, uma no município de Central, BA (Beltrão, et al., 1991) e outra em São Raimundo Nonato, PI (Guidon, 1984). Entretanto, segundo Prous (1997) todos estes registros podem ser questionados com relação às datas, à origem antrópica do material lifico, ou à associação do mesmo com a megafauna, quando presente.

A partir de 15.000 anos AP o panorama do povoamento do continente sutamericano já apresenta evidências que, segundo Barbosa (no prelo), podem ser associadas a claros horizontes cronológicos relacionados a aspectos econômicos das populações, com informações de seus restos alimentares, suas indústrias líticas e sua ação na obtenção de caça.

Para este período, vários complexos culturais são apontados, cujos vestigios arqueológicos compreendem sítios em abrigos e em áreas abertas e 
tecnologias líticas diferenciadas, incluindo instrumentos bifaciais ou unifaciais confeccionados a partir de lascas, e em alguns complexos a presença de pontas de projéteis. Em alguns sítios, há também evidências de associação da cultura material com a megafauna extinta.

Os principais registros, indicados na figura 2.9 com citaçōes de dataçōes e da ocorrência da mega-fauna associada, compreendem os sitios da região de Muaco no Noroeste da Venezuela; a área nuclear de El Abra localizada no noroeste e centro-oeste da Colômbia; a área nuclear de Ayacucho no sudeste do Peru; a área nuclear de El Jobo que se estende do noroeste da Venezuela até o nordeste da Colômbia; Taima-Taima na Venezuela; Malpasso no noroeste da Argentina; Monte Verde no sul do Chile e Guitarrero no norte do Peru.

Para o final do Pleistoceno, outros núcleos são registrados em áreas desérticas e no sul do continente, alguns com dataçōes absolutas, outros com idades relativa baseadas na comparaçăo dos complexos tecnológicos. Neste contexto são registrados os sítios da região de Chivateros, na costa central do Peru; Amotape no Noroeste do Peru, na região de Pampa Salitrera, que hoje corresponde ao grande deserto de Atacama no Chile; Chatchi-Loma Negra, próxima a São Pedro de Atacama; Tagua-Tagua próximo à cidade de Santiago; Quereo I e II em um enclave semi-árido no Chile; Ampajango na Argentina e Los Toldos, na Patagônia (Barbosa, no prelo).

No Brasil os registros incluem os sitios de Ibicui no sudoeste do Rio Grande do Sul; Chapada dos Parecis na região do vale do Guaporé; no Vale do Peruaçú e Lagoa Santa em Minas Gerais; na Lapa do Sol no Amazonas e em São Raimundo Nonato no Piaui (Schmitz, 1994; Prous, 1997) (Figura 2.9).

Com relação aos registros no interior do Brasil, cabe ressaltar que em São Raimundo Nonato $(\mathrm{Pl})$, segundo Guidon (1984), após uma fase de ocupação iniciada há cerca de 32.000 anos AP que perdura até $17.000 \mathrm{AP}$, ocorre uma fase sem registro, seguida do retorno da ocupação por volta de 12.000 anos $A P$, com uma indústria lítica de caráter mais definido.

Quanto à ocupação na região de Lagoa Santa em Minas Gerais, o sítio da Lapa Vermelha, datado em cerca de $12.960 \mathrm{AP}$, permanece até o momento como o único registro com referência mais aceita da associaçäo de restos humanos à megafauna extinta. 


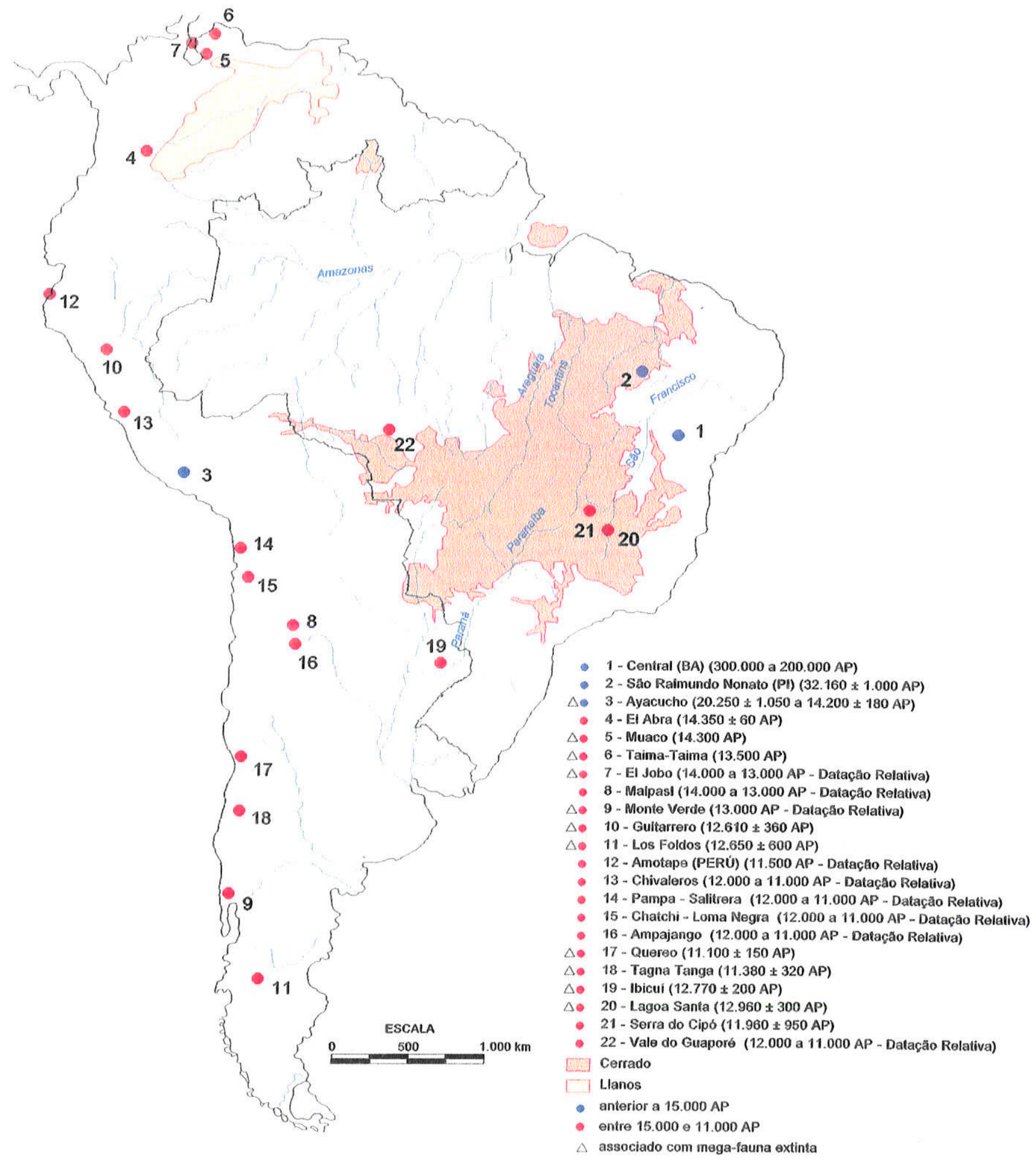

FIGURA 2.9: Localização dos sítios arqueológicos da América do Sul ao final do Pleistoceno (Fontes: Schmitz, 1994; Prous, 1997; Barbosa, no prelo) Organização: Maira Barberi 
Nos sítios da região de Central na Bahia, após a ocupação proposta entre 200.000 e 300.000 anos AP, onde os ossos datados da megafauna extinta foram relacionados a uma indústria lítica muito tosca, os próximos registros de evidências arqueológicas confiáveis situam-se por volta de 6.000 anos AP (Prous, 1991).

A partir de 12.000 anos AP, segundo Barbosa \& Schmitz (1998), há registros de uma intensa movimentação das populações humanas dos núcleos andinos, que coincidiram com mudanças ambientais maiores, de caráter continental, com variações locais, que afetaram a distribuição dos diferentes biomas sul-americanos e podem ter acentuado o processo de redução populacional da megafauna, provocando um empobrecimento qualitativo e quantitativo da caça, principalmente na parte centro-norte ocidental do continente sul-americano.

Estas movimentaçōes provavelmente estiveram relacionadas às entropias nos sistemas físicos, que provocaram uma desestruturação dos complexos culturais estabelecidos. Mesmo que $s €$ considere a açăo mediadora da cultura sobre o ambiente, estes processos não seriam tão efetivos para as culturas do final do Pleistoceno e início do Holoceno, já que mantinham uma economia básica de caça especializada ou caça e coleta, onde a ação da cultura sobre o meio era ainda incipiente (Barbosa et al.,1994).

Esta situação deve ter impulsionado as populaçōes a procurarem novas formas de planejamento ambiental e social, assim como novas alternativas de sobrevivência com o desenvolvimento de diferentes métodos de subsistência. Uma opção seria a área de cerrados.

Neste contexto, o horizonte cultural formado nas savanas e formações xerófilas na região Andina, representados pelas áreas nucleares de El Abra na Colômbia e Ayacucho no Peru, que exploravam formações abertas, podem ter se constituido em centros dispersores.

As formaçōes abertas sugeridas para a região sudoeste e oeste da Amazônia ao final do Pleistoceno, constituiriam áreas favoráveis aos deslocamentos e ao estabelecimento de novos arranjos culturais, desencadeando os processos iniciais de colonização de áreas interioranas do continente, com o estabelecimento de um novo horizonte cultural (Barbosa \& Schmitz, 1998). 
Entre 12.000 e 11.000 anos AP, diversos sistemas ocupacionais começam a ser implantados no interior do continente. Entre os complexos culturais estabelecidos neste período, em que alguns constituem núcleos independentes, dois se sobressaem em função das características da cultura material: um na região sul e o outro na porção oeste do Brasil (Figura 2.9).

O horizonte cultural situado na região das coxilhas gaúchas, com ocupaçōes que se assemelham às ocupações das estepes patagônicas, é caracterizado por uma indústria de lascas finas retocadas e uma grande quantidade de pontas trabalhadas bi-facialmente, e não mostra nenhum tipo de relacionamento com a tecnologia lítica das culturas que se instalaram no Brasil central a partir de 11.000 anos AP (Barbosa \& Schmitz, 1998; Prous, 1997).

$O$ outro sistema ocupacional, localizado no vale do Guaporé em áreas de cerrados, guarda relações com as culturas mais antigas localizadas em áreas de savanas mais a oeste e com as ocupaçōes dos cerrados no interior do Brasil a partir de 11.000 anos AP. É caracterizado por uma indústria lítica bastante típica e marcada pela quase total ausência de pontas de projéteis (Barbosa \& Schmitz, 1998).

A partir de 11.000 anos AP, há registros confiáveis da ocupação humana em áreas de cerrados em outras regiöes do Brasil. Segundo Knipis (1998), embora diversos sítios arqueológicos da América do Sul e especificamente do Brasil Central apresentem datas sincrônicas aos sitios encontrados na América do Norte, as ocupaçōes sul-americanas apresentam caracteristicas diferentes das ocupaçōes paleo-indigenas norte americanas onde um horizonte cultural denominado cultura Clovis, é caracterizado por caçadores especializados, com uma indústria lítica de pontas de projéteis acanaladas (Meltze 1989, apud Dillehay, 1997a).

O horizonte cultural estabelecido no Planalto Central e áreas vizinhas no final do Pleistoceno e início do Holoceno que apresenta uma marcante relaçäo com as áreas atualmente recobertas pelo bioma Cerrado, ou próximas ao contato do Cerrado com a Caatinga, constitui, segundo Barbosa \& Schmitz (1998) a Tradição Itaparica que se distribui em uma área extensa com assentamentos a céu aberto e sítios em abrigos (Figura 2.10). 


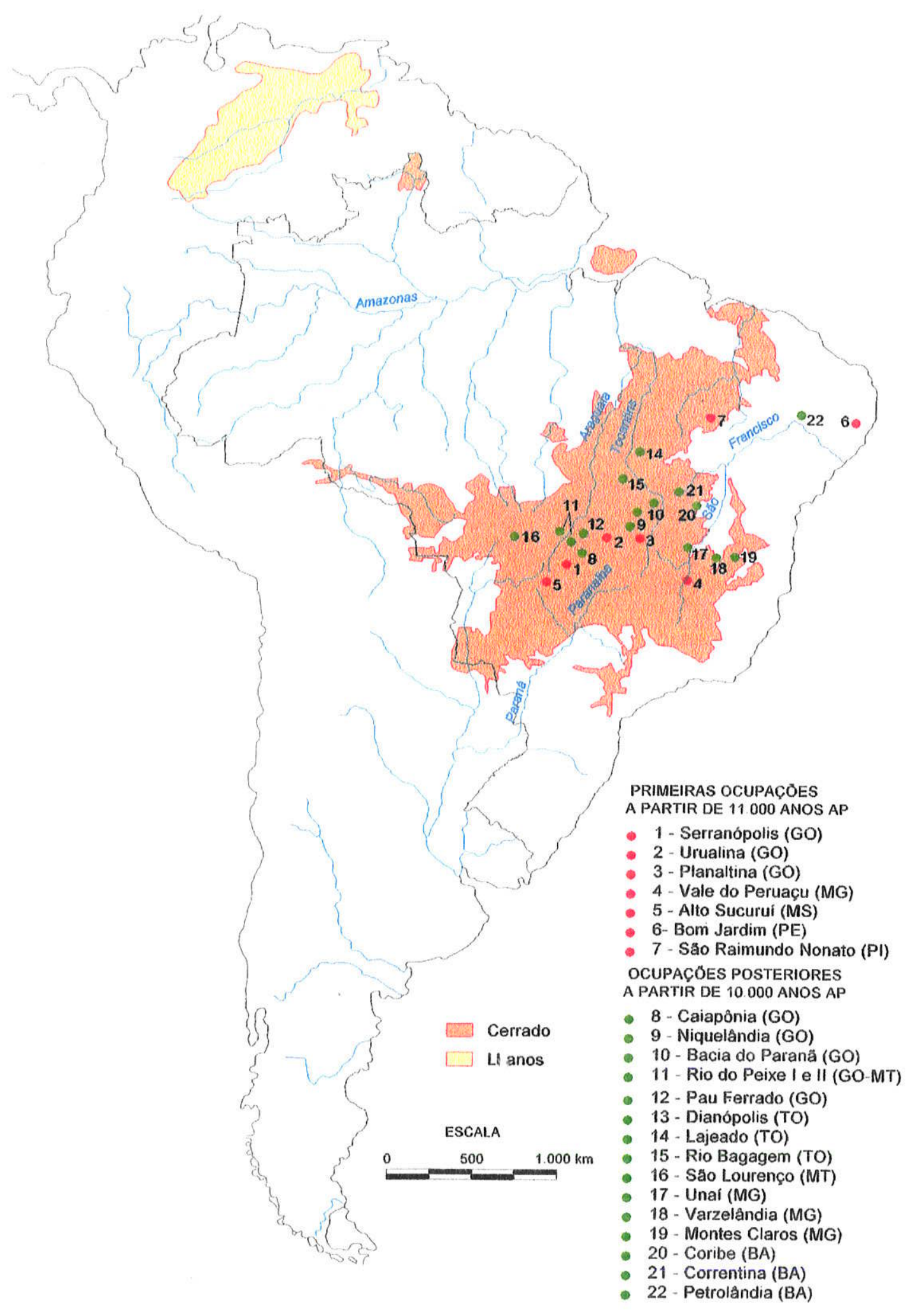

FIGURA 2.10: Distribuição da Tradição Itaparica (Fontes: Schmitz, et al., 1986; 1989; Barberi, 1988; Schmitz, 1994; Prous, 1997; Barbosa, no prelo) Organização: Maira Barberi 
Abrange sítios situados na quase totalidade dos estados de Goiás e parte do Tocantins, Mato Grosso e Mato Grosso do Sul, grande parte de Minas Gerais, o oeste da Bahia, provavelmente parte de São Paulo, além de áreas atualmente recobertas pela caatinga em Pernambuco e no Piaui, estendendo-se por cerca de $2.000 .000 \mathrm{~km}^{2}$.

As primeiras ocupações, a partir de 11.000 anos AP, estão representadas nos sítios arqueológicos de Serranópolis, Urualina e Planaltina em Goiás, no vale do Peruaçú em Minas Gerais, no Alto Sucuruí em Mato Grosso do Sul, Bom Jardim em Pernambuco e São Raimundo Nonato no Piaui (Figura 2.10).

As ocupaçōes posteriores, a partir de 10.000 até 8.500 anos AP, tornam-se mais abundantes e incluem os sítios de Caiapônia, Niquelândia, Bacia do Paranã, Rio do Peixe I e Il e Pau Ferrado em Goiás, Dianópolis, Lajeado e rio Bagagem no Tocantins, São Lourenço no Mato Grosso, Unaí, Varzelândia e Montes Claros em Minas Gerais, Coribe e Correntina na região dos Gerais na Bahia e em Petrolândia no estado de Pernambuco (Figura 2.10) (Schmitz, et al.,1986; 1989; Barberi, 1988; Schmitz, 1994; Prous, 1997; Barbosa, no prelo).

Correspondem a assentamentos a céu aberto ou em abrigos calcários, areníticos ou quartzíticos, freqüentemente com manifestaçōes de pinturas rupestres, nos quais não há qualquer evidência de associação com megafauna extinta.

A tradição tecnológica Itaparica, posicionada cronologicamente a partir de 11.000 até cerca de 9.000 a 8.500 anos AP, é caracterizada por um artesanato lítico bem elaborado onde se sobressaem os raspadores unifaciais planoconvexos, denominados lesmas, além de outras peças como lâminas, talhadores, machados e mós, lascados e retocados por percussão e pressão, atendendo às funções de cortar, furar, raspar, alisar e esmagar, compondo uma indústria lítica intimamente ligada às formas de exploração dos cerrados (Figura 2.11).

Este conjunto tecnológico representa a cultura material de um caçador e coletor generalizado que explora nichos diversificados e criou mecanismos responsáveis por um sistema econômico, que perdurou por 2.500 anos, porém com aperfeiçoamentos bem especificos dando origem a uma cultura singular e bastante homogênea (Schmitz, 1994; Barbosa \& Schmitz, 1998). 


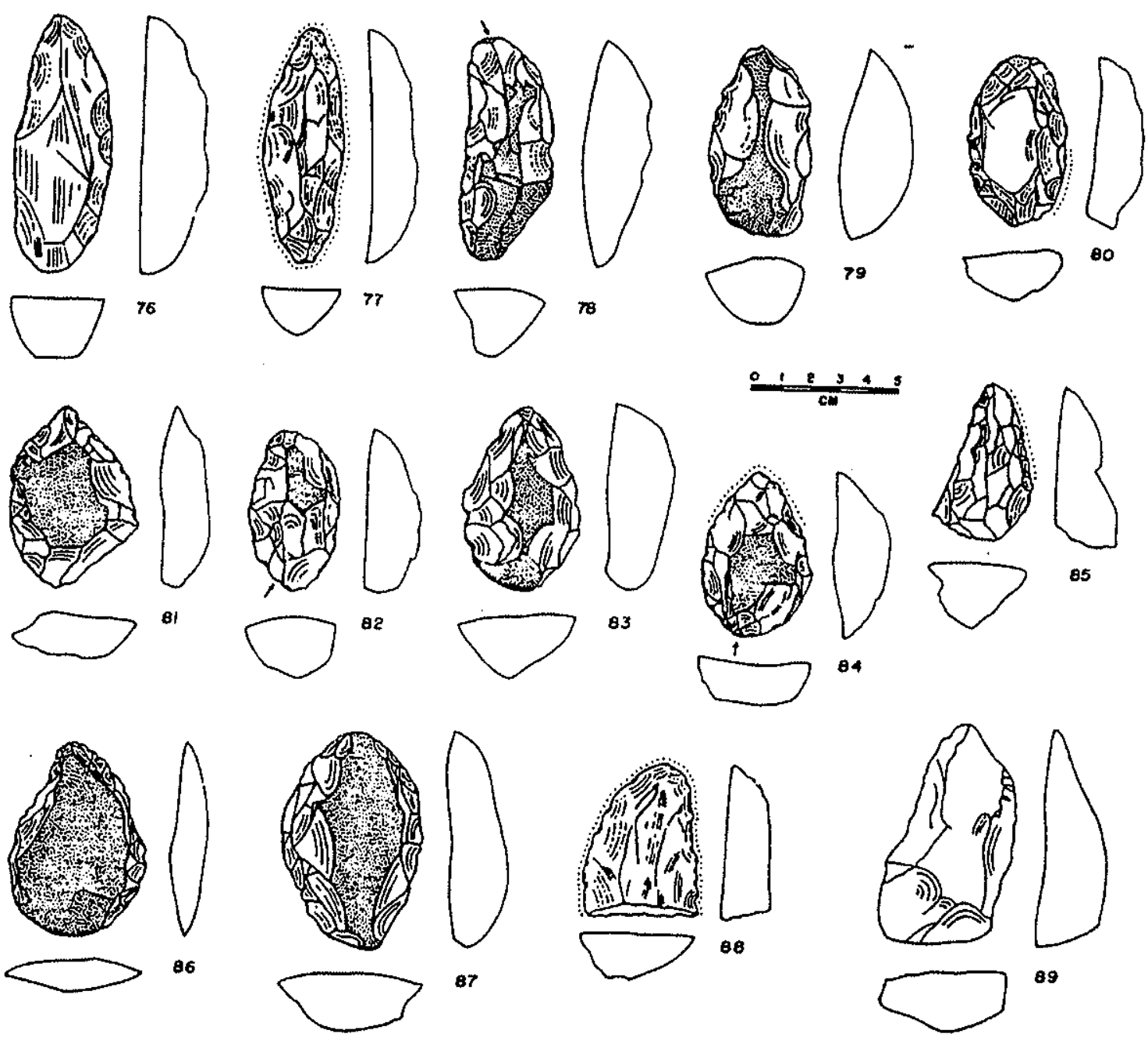

FIGURA 2.11: Artefatos líticos plano-convexos, trabalhados como raspadores, característicos da Tradição Itaparica (Fonte: Schmitz et al., 1986)

Segundo Barbosa \& Schmitz (1998), os fatores que influenciaram a presença da Tradição Itaparica em áreas de cerrados compreendem um conjunto de aspectos bióticos e abióticos.

Entre os fatores abióticos encontra-se a estabilidade climática com dois ciclos definidos, que facilitaria às populações uma economia simples e a adoção de um planejamento homogêneo. Além disso, a presença de abrigos naturais permitia a esses grupos humanos se estabelecerem em determinadas épocas do ano e a ocorrência de blocos de quartzitos e de seixos de quartzo, sílex e quartzitos propiciaria a matéria prima para a confecção de instrumentos. 
Entre os aspectos bióticos, destacam-se nas diferentes fitofisionomias do bioma cerrado, a ocorrência de recursos vegetais como fibras, lenhas, folhas ásperas para acertar superficies, palhas de palmeiras para cobertura de abrigos, e grande variedade de frutos comestiveis. Embora a maior parte destes frutos tenha uma maturação relacionada à estação da chuva, a variedade possibilita uma distribuição regular ao longo do ano.

A atividade de caça não-especializada seria favorecida pela grande concentração nos cerrados, de uma fauna relacionada à província zoogeográfica de vegetação aberta, o que se deve à ocorrência de um extrato graminoso contínuo, à presença de flores e frutos, além da diversidade do bioma com suas diferentes fitofisionomias, permitindo a instalação de uma cadeia biológica complexa.

Para a captura destes animais como veados, capivaras, macacos, tamanduás, tatus, tartarugas, lagartos e emas, as técnicas mais apropriadas incluiriam utilização de armadilhas, porretes e o uso do fogo para isolar animais e não mais o dardo com ponta de pedra finamente trabalhada, característica dos caçadores de grandes animais gregários da mesma época, nas estepes americanas do Norte e do Sul (Schmitz, 1994; Barbosa \& Schmitz, 1998).

A partir da análise do ciclo de abastecimento, Barbosa \& Schmitz (1998) estabeleceram um modelo que representa a organização espacial e 0 comportamento cultural destas populaçöes paleo-indigenas, cujo sistema econômico era sustentado pela coleta generalizada de frutos, raízes, insetos, mel e ovos de emas, pela pesca e pela caça de animais de pequeno porte.

Este modelo controlado pela maior ou menor disponibilidade de recursos nas estaçōes chuvosas ou secas, resultaria na formação de bandos maiores ou menores, na divisão do trabalho por faixa etária e por sexo e em uma maior ou menor mobilidade do bando.

Segundo Barbosa \& Schmitz (1998), este complexo cultural, onde predominam furadores e raspadores terminais, instalado no Planalto Central em áreas de cerrados, permanece entre 11.000 e 8.500 anos AP, quando aparecem isoladas pontas de projéteis pedunculadas.

O final da Tradição Itaparica ocorreu por volta de 9.000 a 8.500 anos AP quando esta cultura perde suas características básicas de artefatos bem 
trabalhados, sendo substituida ou transformada em uma cultura cuja indústria lítica é marcada por lascas com poucos retoques, indicando alteraçōes no sistema econômico, possivelmente relacionadas às mudanças nos recursos naturais disponiveis devido a modificações ambientais.

O novo horizonte cultural instalado no Planalto Central em áreas de cerrados é denominado de Tradição Serranópolis e abrange o periodo entre 8.500 e 6.500 anos AP. Compreende um novo complexo tecnológico onde instrumentos pouco elaborados, menores e produzidos por novas técnicas, substituem os instrumentos líticos bem elaborados do periodo anterior. Como matéria prima, além de quartzo e quartzito passam a ser utilizados conchas e ossos.

Em alguns locais como nos abrigos de Bom Jardim (PE) e em pequena quantidade em Minas Gerais e São Paulo, começam a aparecer pontas foliáceas bifaciais em quartzo hialino, indicando um novo tipo de caça ou uma nova tecnologia (Schmitz, 1994).

Estas modificações na cultura material refletem modificações acentuadas no sistema de abastecimento, inferidas a partir dos restos alimentares, onde os moluscos terrestres passam a ocupar uma posição de destaque, associados a frutos em grande quantidade e a uma caça muito reduzida.

Nas seqüências estratigráficas acumuladas nos abrigos de Serranópolis, sudoeste de Goiás, constata-se também um aumento nas camadas de cinzas das fogueiras acesas no interior dos abrigos, indicando maior tempo de ocupação ou maior número de pessoas, e o registro de sepultamentos que passam a ser numerosos (Schmitz et al., 1989; Barbosa et al., 1994). Os sítios ao ar livre não são mais registrados nesta região, embora continuem ocorrendo em áreas como Pernambuco, Bahia e São Paulo (Schmitz, 1994).

A partir de 6.500 AP o registro de ocupaçōes pré-históricas nas regiōes anteriormente ocupadas pelas populações da Tradição Serranópolis muda completamente. Alguns abrigos em São Paulo, Pernambuco, Tocantins e Minas Gerais, passam a apresentar indústrias líticas diversificadas e mais localizadas. Outros, intensamente utilizados nas fases anteriores, como os de Serranópolis (GO), os do sul do Piauí, de Pernambuco e Minas Gerais, tornam-se desocupados ou apresentam evidências de ocupações esporádicas. 
Segundo Schmitz (1994), estas alterações na seqüência cultural estariam relacionadas a um aumento acentuado da temperatura e da umidade, que tornariam os abrigos demasiadamente úmidos e quentes ou pouco ventilados, ou provocaria uma mudança dos recursos nas proximidades dos mesmos.

A análise dos novos complexos culturais registrados em outras áreas e dos novos grupos que se instalam em áreas de cerrados do Planalto Central brasileiro, após um hiato de tempo considerável, leva a supor que o extenso horizonte cultural da Tradição Serranópolis foi substituido lentamente por um mosaico de novas culturas diversas, que se desenvolveram segundo diferentes tradições, adaptadas à condições locais especificas.

Esta fase de rarefação da ocupação no interior do continente verificada a partir de 6.500 anos AP parece coincidir com o desenvolvimento dos grupos do litoral, embora até o momento não tenha sido apontada nenhuma relação de causa e efeito entre os dois fenômenos (Schmitz, 1994).

Pouco se conhece sobre a passagem das culturas de caçadores e coletores genéricos que permaneceram do inicio do Holoceno até cerca de 6.500 anos AP, para os diferentes grupos de ceramistas e agricultores, que se estabeleceram no Planalto Central.

Em abrigos com depósitos estratificados como Serranópolis $(G O)$ há descontinuidade entre as camadas que registram a ocupação das culturas essencialmente líticas e os grupos ceramistas, indicando um hiato bem marcado entre os dois tipos de ocupação. Nas áreas onde as aldeias ceramistas se estabeleceram ainda não foram encontrados sítios pré-cerâmicos (Barbosa et al., 1994; Barbosa, no prelo).

Os primeiros grupos ceramistas registrados no bioma Cerrado, utilizando em algumas situações os abrigos ocupados anteriormente pela Tradição Itaparica, porém sem evidência clara de transição, surgem por volta de 2.400 anos $A P$, num periodo em que $o$ ambiente era supostamente semelhante ao atual.

A partir da comparação destas datas com o registro de cerâmica em regiōes próximas, cerca de 5.000 anos AP no Pará e 4.000 anos AP em Minas Gerais, fica claro que os cultivos não surgiram nesta área, já que as tecnologias implantadas no Planalto Central pertencem a horizontes mais amplos, cujas datas 
mais antigas estão fora da região. Segundo Barbosa (no prelo), os cultivos poderiam ter chegado através da migração de grupos horticultores, pela aculturação dos caçadores e coletores, ou muito provavelmente pelos dois processos.

Os grupos ceramistas identificados no Planalto Central apresentam diferentes sistemas econômicos e uma distribuição espacial que não possibilita mais uma tentativa de correlação com a área de distribuição dos cerrados.

São classificados em cinco grandes tradiçōes tecnológicas com características específicas quanto à forma de manufatura da cerâmica, o material utilizado na confecção da mesma e a forma dos recipientes, o que indica diferenças com relação às plantas processadas. $A$ indústria lítica associada aos grupos ceramistas inclui machados polidos, mãos de pilão, panelas rasas, pilōes trabalhados em pedra sabão, além de adornos como tembetás de quartzo e carimbos cilíndricos utilizados na ornamentação corporal (Silva, 1995).

O grupo mais antigo é representado pela Fase Pindorama, de tradição não definida, datado de 2.400 anos AP. Foi identificado no estado do Tocantins e compreende sítios a céu aberto e em abrigos que ocupam predominantemente áreas com domínio dos cerrados (Silva, 1995).

A Tradição lito-cerâmica Una, cujas idades mais antigas alcançam 1.500 anos AP, representa grupos que ocupavam vales enfurnados e utilizavam abrigos para habitação. Apresentavam uma economia onde exerciam certo dominio sobre plantas cultivadas onde se destaca o milho, além de amendoim e curcubitáceas, porém fortemente apoiada pela coleta de frutos e moluscos e pela caça. Distribuiu-se em áreas no sudoeste do estado de Goiás, no centro-oeste de Minas Gerais e no oeste da Bahia, na bacia do rio Corrente, formando pequenas sociedades com condições de explorarem recursos diversificados.

A Tradição Aratu representa os primeiros aldeões conhecidos que ocuparam áreas férteis no centro-sul e leste de Goiás e no centro-oeste de Minas Gerais e oeste do Mato Grosso. Apresentam uma economia mais dependente de cultivos baseados em tubérculos e provavelmente milho, sem dispensar a exploração dos frutos do cerrado, a caça e a pesca. Constituiam aldeias populosas que desembocaram em grupos coloniais $e$, suas datas mais antigas situam-se em torno de 1.100 anos AP (Silva, 1995). 
A Tradição Uru compreende grupos de agricultores das bacias dos rios Tocantins e Araguaia, apresentando aspectos tecnológicos amazônicos. Seus restos alimentares não são conhecidos, mas a partir da forma da cerâmica e da posição das aldeias é sugerida uma economia baseada no cultivo da mandioca amarga e da pesca.

As idades relacionadas a estas aldeias com populaçöes numerosas que avançavam ao longo dos rios ocupando terrenos baixos, estão em torno de 900 a 800 anos $A P$, indicando uma chegada ao Planalto Central em épocas mais recentes que os agricultores da Tradição Aratu (Silva, 1995).

Os últimos ceramistas que atingiram o Planalto Central, em torno de 600 anos AP, são representados pela Tradição Tupi-Guarani, com características de grupos mandioqueiros. Apresentam ocupações esparsas na bacia do Araguaia e mais rarefeitas no resto do estado de Goiás. Segundo Barbosa (no prelo) aparentemente enfrentaram dificuldades na ocupação de um espaço anteriormente ocupado pelos outros dois grupos de agricultores aldeões das Tradições Aratu e Uru.

A distribuição dos grupos agricultores do Planalto Central mostra um padrão dissociado da ocorrência do bioma cerrado, provavelmente influenciado pelos deslocamentos dos grupos ceramistas anteriormente estabelecidos em áreas vizinhas e não mais pela distribuição dos recursos naturais, uma vez que com o desenvolvimento da agricultura passaram a exercer maior controle sobre o abastecimento.

Dos grupos com ampla distribuição no Planalto Central, a Tradição Una que ocupou os abrigos, detém as idades mais antigas para a cerâmica. Aparentemente mantinham um menor dominio sobre as áreas abertas, ocupando umas faixas entre os grandes aldeões das Tradições Uru e Aratu e as populaçōes coletoras cultivadoras do planalto meridional, conhecidas por suas aldeias de casas subterrâneas. Segundo Barbosa (no prelo), apesar de sua posição marginal, suas idades antigas poderiam indicar uma instalação anterior aos aldeões ou eventualmente a origem destes.

Os dois outros grupos de ceramistas com ampla distribuição, que estabeleceram grandes aldeias no Planalto Central, representados pelas Tradições Uru e Aratu ocuparam espaços bem delimitados e marcaram fronteiras 
nítidas. A Tradição Aratu mais antiga, com uma tecnologia voltada para o cultivo de milho e amendoim, apresenta uma dispersão mais oriental, enquanto a Tradição Uru com uma tecnologia de processamento da mandioca, indicando uma possivel origem a partir de grupos amazônicos, apresenta dispersão mais ocidental.

A seqüência de ocupação do Planalto Central após os grupos ceramistas definidos através de vestígios arqueológicos, relaciona-se ás populaçōes indigenas coloniais, bem estabelecidas e contatadas inicialmente pelo avanço das primeiras bandeiras no século XVIII.

Estes grupos indigenas provavelmente se desenvolveram a partir das comunidades que constituiram as diferentes tradições arqueológicas estabelecidas anteriormente. Segundo Barbosa (no prelo), esta estabilidade é sugerida pela presença de numerosas taperas de aldeias sucessivas de uma mesma cultura e tecnologia, que se sobrepõem durante muitos séculos em um mesmo local, fato observado para quase todas as tradições arqueológicas.

Entretanto, novamente são dificeis de serem estabelecidas as correlaçõos entre as tradições ceramistas e os grupos indigenas coloniais. As tradiçōes arqueológicas baseiam-se em evidências da cultura material, principalmente a cerâmica, enquanto as populações indígenas são classificadas a partir das diferenças lingüísticas e dos aspectos da cultura simbólica, para os quais não há registros arqueológicos. As tentativas de correlações procuram basear-se na distribuição espacial dos grupos, e na comparação dos aspectos da cultura material dos grupos coloniais com os parâmetros que definem as tradições arqueológicas.

Não hả uma estimativa para a população indígena colonial distribuida no Planalto Central ao início da colonização. Entretanto, há referências históricas, indicando populações numerosas, alcançando 3.000 indios ou mais para muitos grupos. Os contatos diretos com os bandeirantes provocaram uma profunda desagregação social.

Os grupos mais hostis que apresentavam resistência eram dizimados e os arredios, após a desintegração das aldeias, se deslocavam em grupos menores. Aqueles que ofereciam um contato pacifico eram freqüentemente escravizados ou 
aldeados, o que levava também a uma queda acentuada na população e principalmente a uma desestruturação de seus complexos culturais.

Segundo Barbosa (no prelo) a população indígena atual que ocupa áreas do bioma cerrado é de cerca de 44.000 habitantes, compreendendo 26 povos de características culturais diferentes, pertencentes a diferentes familias lingüisticas, distribuidos principalmente em terras do Maranhão.

Segundo Aragão (1994), as incursões das bandeiras com a conseqüente descoberta do ouro em Goiás, promoveram um novo padrão de ocupação das áreas dos cerrados, caracterizado por uma economia de subsistência, com pequeno excedente de produção e ênfase no lazer, criando uma cultura caipira, que vigorou de forma praticamente inalterada durante dois séculos e meio.

Com a criação de Brasília e a expansão da fronteira agricola, voltada para uma pecuária extensiva e o cultivo de soja, as áreas de cerrados até entăo consideradas de pouca produtividade devido à baixa fertilidade do solo, passaram a constituir foco de atenção. Aspectos como a estabilidade climática, a existência de áreas planas e de solos profundos que permitiam a agricultura mecanizada e a possibilidade de correção da acidez do solo, passaram a constituir elementos importantes e favoráveis à implantação de uma agricultura extensiva.

A partir da década de setenta, com a intensificação do enfoque político voltado ao sistema produtivo e à acumulação de capital, ocorre na área rural um aumento das agroempresas, resultando na formação de grandes latifúndios voltados para a produção de grãos, provocando inicialmente a inviabilização das pequenas propriedades, a desestruturação da cultura caipira e conseqüentemente o êxodo rural (Aragão, 1994).

Entretanto, para o bioma Cerrado, como ecossistema com suas diferentes fitofisionomias, a conseqüência direta da implantação de um novo sistema de produção foi a redução acentuada da cobertura vegetal do cerrado no sentido lato, que no início da década de 90 já atingia cerca de $50 \%$ (Ratter, 1994).

\subsubsection{Vegetação na área de estudo}

Regionalmente, na porção nordeste do Distrito Federal, em uma área com aproximadamente $160 \mathrm{~km}^{2}$ que compreende a Reserva Biológica de Águas 
Emendadas onde se encontram a Lagoa Bonita e a turfa do córrego Brejinho estudada por Barberi (1994), ocorre um mosaico de fitofisionomias características do bioma Cerrado, cujos limites foram definidos a partir de fotointerpretação e mapeamento sistemático (Figura 2.12).

Grande parte da área é ocupada por um Cerrado no sentido restrito com variações na densidade da cobertura arbórea provavelmente relacionadas às modificações nos solos. Nas áreas aplanadas em que aflora o lençol freático, como nas proximidades do córrego Brejinho, a vegetação é marcada pela presença da vereda junto à drenagem e um campo limpo úmido nas proximidades.

Nos locais onde a superficie aplanada foi dissecada de forma mais pronunciada, como no córrego Vereda Grande, que flui para a bacia hidrográfica do rio Maranhão, ocorre uma mata úmida ou mata de galeria (Barberi,1994).

Nos últimos trinta anos a área em questão foi intensamente ocupada pela expansão das cidades satélites que provocaram inicialmente uma redução nas matas de galerias. Posteriormente, as áreas aplanadas foram utilizadas para plantio ou formação de pastagens, resultando em uma modificação acentuada na cobertura vegetal que pode ser observada na imagem de satélite Landsat (TM-5) tratada em composição colorida para ressaltar a vegetação com as bandas 3 no azul, 4 no verde e 5 no vermelho (Figura 2.13).

Mais localmente, na região da Lagoa Bonita e entorno, a distribuição da vegetação é marcada pela ocorrência de três fitofisionomias do bioma Cerrado: o Cerrado no sentido restrito, incluído entre as formaçōes savânicas, o Campo Limpo Úmido, incluído entre as formações campestres e a Vereda, incluída na nova categoria estabelecida de formações palustres (Figura 2.14).

O Cerrado no sentido restrito, na sua forma de Cerrado Típico, ocorre no entorno da lagoa a partir do inicio do talude, sobre os Latossolos VermelhoEscuros distróficos, distante cerca de $500 \mathrm{~m}$ das margens atuais da lagoa.

Esta fitofisionomia de ampla ocorrência no Planalto do Distrito Federal é caracterizada, segundo Ribeiro \& Walter (1998) e Eiten (1994), pela presença dos estratos arbóreo-arbustivo e herbáceo bem definidos, com as árvores distribuídas aleatoriamente sobre o terreno com diferentes densidades. 


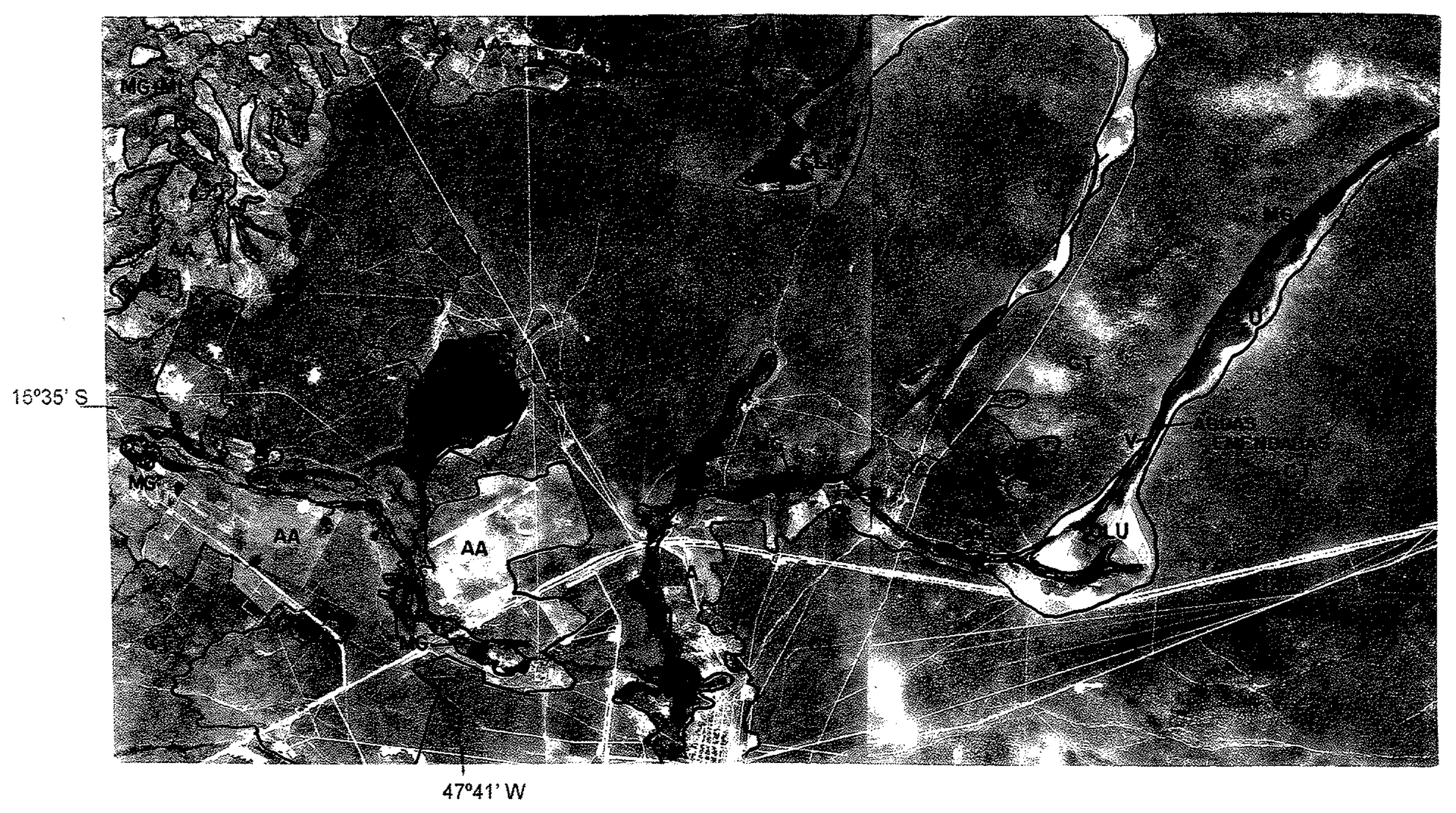

$V$ - Vereda

MG - Mata de galeria

MI - Mata de interflúvio
CT - Cerrado típico

CD - Cerrado denso

CLU - Campo limpo úmido
AA - Área antropizada

Escala $\approx 0$

$1.600 \mathrm{~m}$
NG

g

Figura 2.12: Distribuição da vegetação regional (Fonte: fotos aéreas 43726 e 46718 USAF/1965 Escala 1:60.000) 


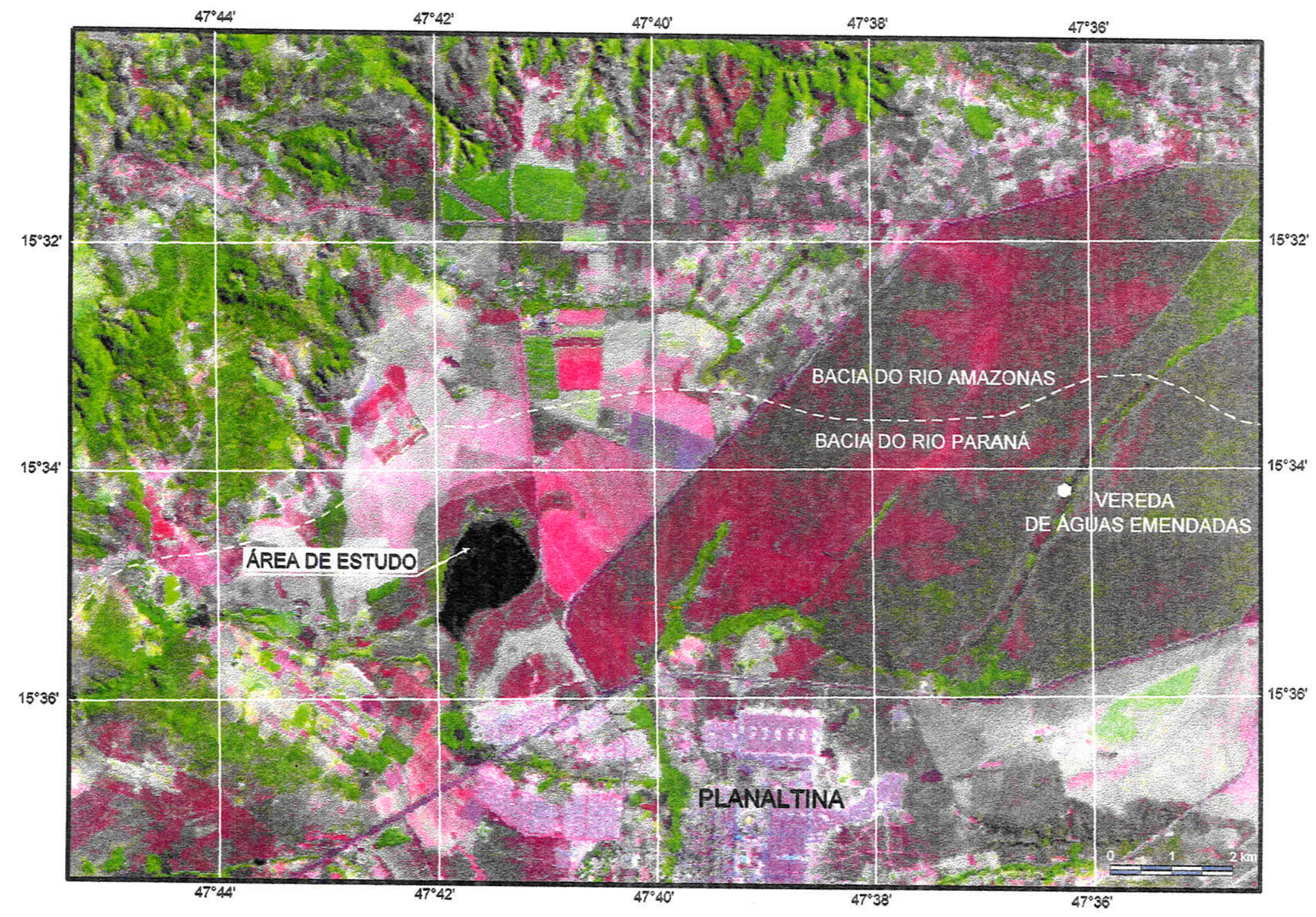

FIGURA 2.13: Distribuição da vegetação regional em 1997 (Fonte: Imagem satélite Landsat - TM 5, 1997) Organização: Péricles Prado 


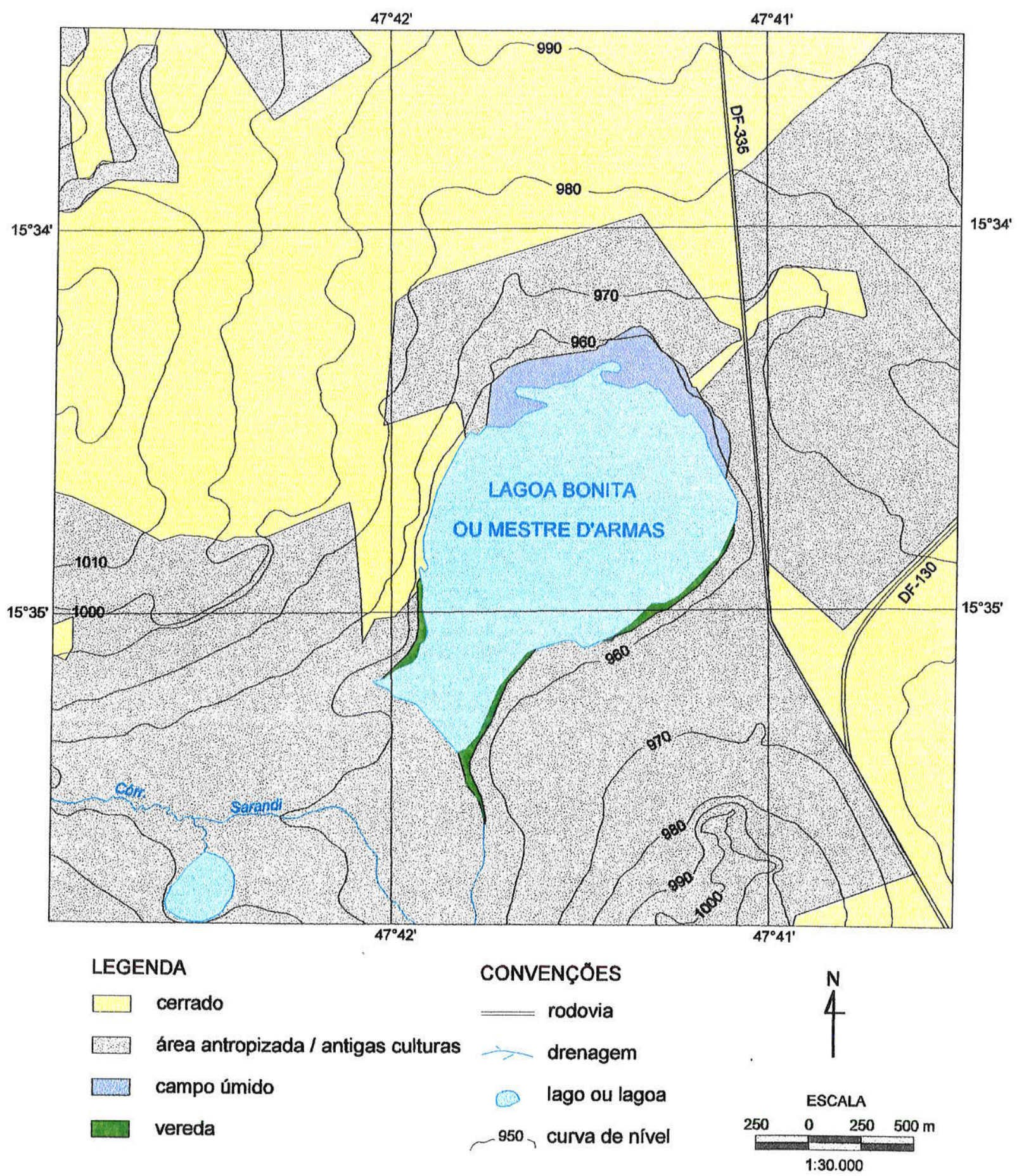

FIGURA 2.14: Distribuição da vegetação no entorno da Lagoa Bonita, DF Organizaçăo: Maira Barberi 
Estas variações nas densidade da cobertura arbórea, ocorrem em função de fatores fisicos e químicos como condições edáficas, $\mathrm{pH}$, saturação de alumínio, fertilidade, condiçōes hídricas, profundidade do solo, além da freqüềncia de queimadas e ações antrópicas (Figura 2.15).

No Cerrado Típico a cobertura arbórea atinge 20 a $50 \%$ com altura média de 3 a $6 \mathrm{~m}$, não formando dossel arbóreo contínuo. A camada arbustiva é composta de arbustos, arvoretas e palmeiras que somados à cobertura arbórea perfazem até $60 \%$ da área. O restante é ocupado pelo extrato herbáceo, que é quase sempre fechado, contínuo e predominantemente graminoso (Figura 2.16).

A vegetação local caracteriza-se pela presença de árvores baixas, inclinadas, tortuosas, com ramificações irregulares e retorcidas, geralmente com evidências de queimadas. Os troncos das plantas lenhosas possuem geralmente cascas com cortiça grossa, fendida ou sulcada $e$ as folhas são rígidas $e$ coriáceas, caracteres que constituem um aspecto de adaptação às condiçōes de seca (xeromorfismo).

Apesar deste aspecto xeromórfico, já relatado por Warming (1908) nos primeiros trabalhos sobre o cerrado, há vasta literatura relatando que as plantas arbóreas, ao menos as espécies que possuem raizes profundas, não sofrem restrição hidrica durante a estação seca.

Quanto à composição florística, Ratter et al. (1996), comparando diversos trabalhos publicados sobre a vegetação do Cerrado no sentido restrito, obtiveram uma relação das espécies arbóreas mais características, entre as quais se incluem Acosmium dasycarpum (amargozinha), Brosimum gaudichaudii, Byrsonima coccolobifolia (murici), Curatella americana (lixeira), Erythroxylum suberosum, Hancomia speciosa (mangaba), Kielmeyera coriacea, Lafoensia pacari, Roupala montana (carne de vaca), Tabebuia aurea e outras. Também são freqüentes Enterolobium ellipticum (vinhático cascudo), Ourathea hexasperma (cabeça de negro) Salacia crassifolia (bacupari) e Sclerolobium aureum (carvoeiro).

Entre as espécies arbustivas mais freqüentes destacam-se elementos das famílias Euphorbiaceae, Leguminosae, Rubiaceae, Palmae, Compositae e outras. O extrato inferior herbáceo é constituido basicamente por elementos da familia Poaceae (Gramineae). 


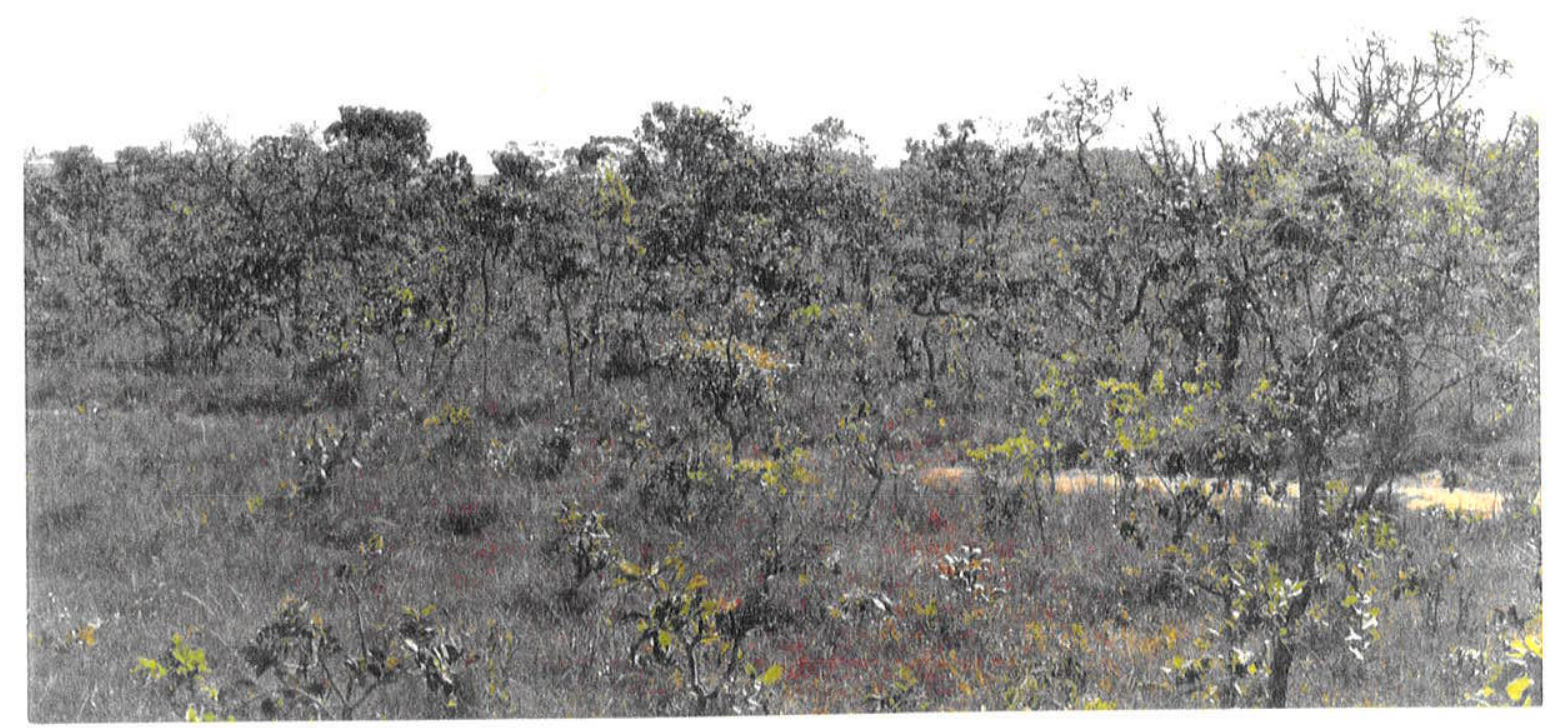

FIGURA 2.15: Aspecto característico do Cerrado Típico do entorno da Lagoa Bonita, DF

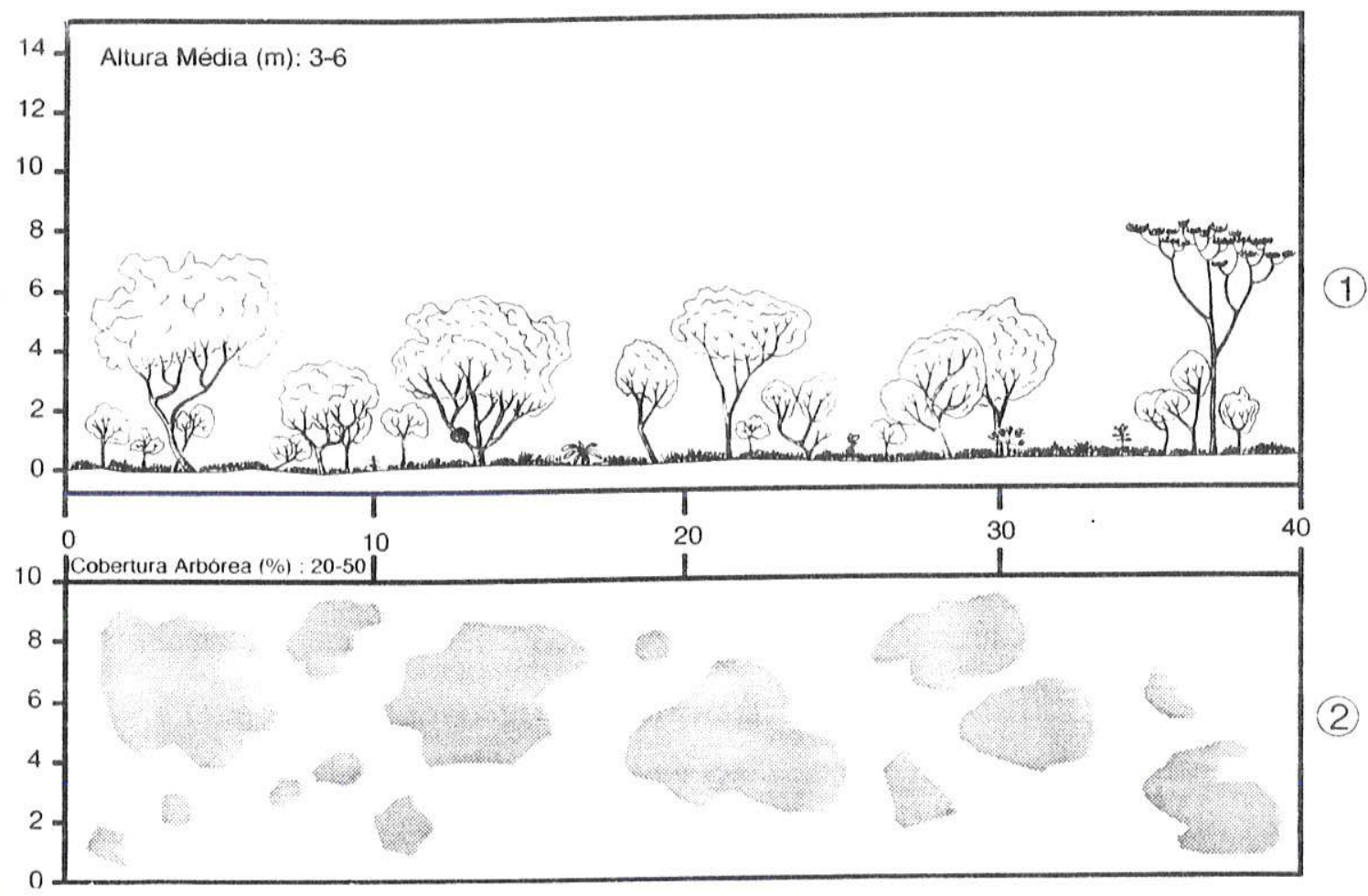

FIGURA 2.16: Diagrama de Perfil (1) e cobertura arbórea (2) de um Cerrado Típico representando uma faixa de $40 \mathrm{~m}$ de comprimento por $10 \mathrm{~m}$ de largura (Fonte: Ribeiro \& Walter, 1998) 
Nas regiões de Planaltina (Ribeiro et al. 1985) e do Parque Nacional das Emas (Álvares da Silva, 1996) no sudoeste goiano, áreas consideradas nucleares do bioma Cerrado com ocorrência de Cerrado Típico, algumas famílias se destacam: Leguminosae, Myrtaceae, Malpighiaceae, Vochysiaceae e Compositae.

Feifili (1998), trabalhando na Estação Ecológica de Águas Emendadas, mostra também a alta similaridade da região com áreas de Cerrado no sentido restrito, estudadas na Chapada dos Veadeiros, onde se destacam Ascomium, Byrsonima, Connarus, Erythroxylum, Kielmeyera, Ouratea, Sclerolobium e Tabebuia, consideradas espécies típicas do Brasil Central.

A segunda fitofisionomia, com ocorrência na área, é representada pelo Campo Limpo Úmido, também chamado de Campo de Várzea ou Várzea, uma sub-unidade do Campo Limpo, incluido entre as formações campestres do bioma Cerrado. Ocorre em uma faixa que se estende das proximidades da margem da lagoa até o início do talude, em áreas com ocorrência de solos hidromórficos com lençol freático raso e condições redutoras (Figura 2.17).

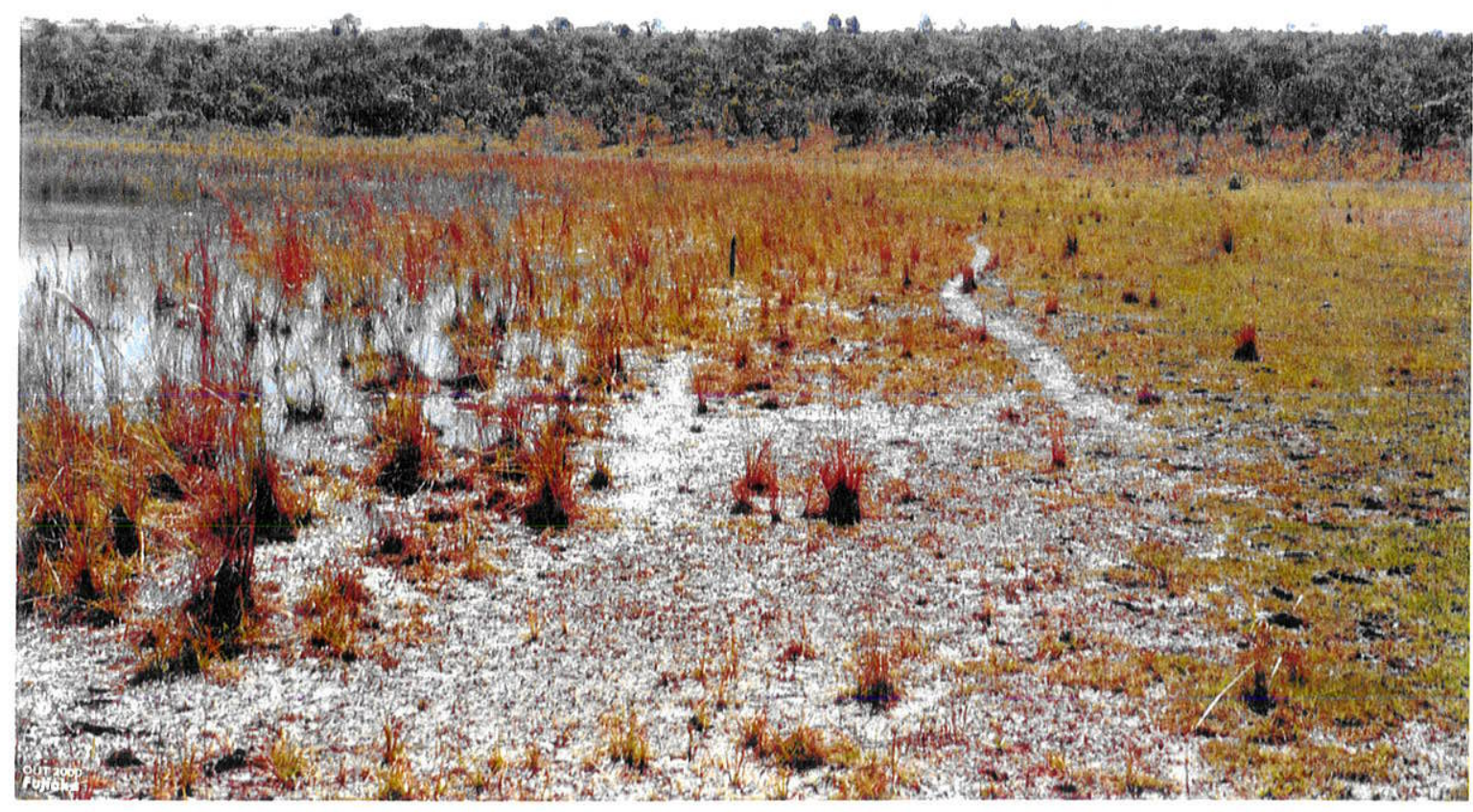

FIGURA 2.17: Aspecto característico de um Campo Limpo Úmido no entorno de lagoas na região de Planaltina, DF 
Caracteriza-se pela predominância do estrato herbáceo, com raros arbustos e ausência completa de árvores. As espécies normalmente encontradas pertencem às familias Cyperaceae, Droseraceae, Lentibulareaceae, Lythraceae e Gramineae (Poaceae).

A Vereda, incluida neste trabalho entre as fitofisionomias das formações palustres, tem sua ocorrência na área restrita às proximidades da Lagoa Bonita e das margens do córrego Mestre D'Armas. É caracterizada pela presença da palmeira arbórea Mauritia flexuosa, com altura média entre 12 e $15 \mathrm{~m}$ com uma cobertura de $5 \%$ a $10 \%$, não formando dossel contínuo. Na Vereda, os buritis apresentam-se emergentes em meio a agrupamentos mais ou menos densos de espécies arbustivo-herbáceas (Ribeiro \& Walter, 1998) (Figura 2.18 e 2.19).

A presença da Vereda, que normalmente ocupa vales ou áreas planas acompanhando linhas de drenagem mal definidas ou nascentes, está condicionada ao afloramento do lençol freático e à ocorrência de solos hidromórficos saturados durante a maior parte do ano (Ribeiro \& Walter, 1998).

Grande parte da área do entorno da Lagoa Bonita esteve ocupada, até a sua inclusão na Estação Ecológica de Águas Emendadas, por culturas diversas resultantes da ação antrópica e por pequenos capões de mata reflorestada.

Atualmente, a região encontra-se em fase de recuperação, embora esta ocorra de forma aleatória, sem o acompanhamento de um programa científico sistemático. 


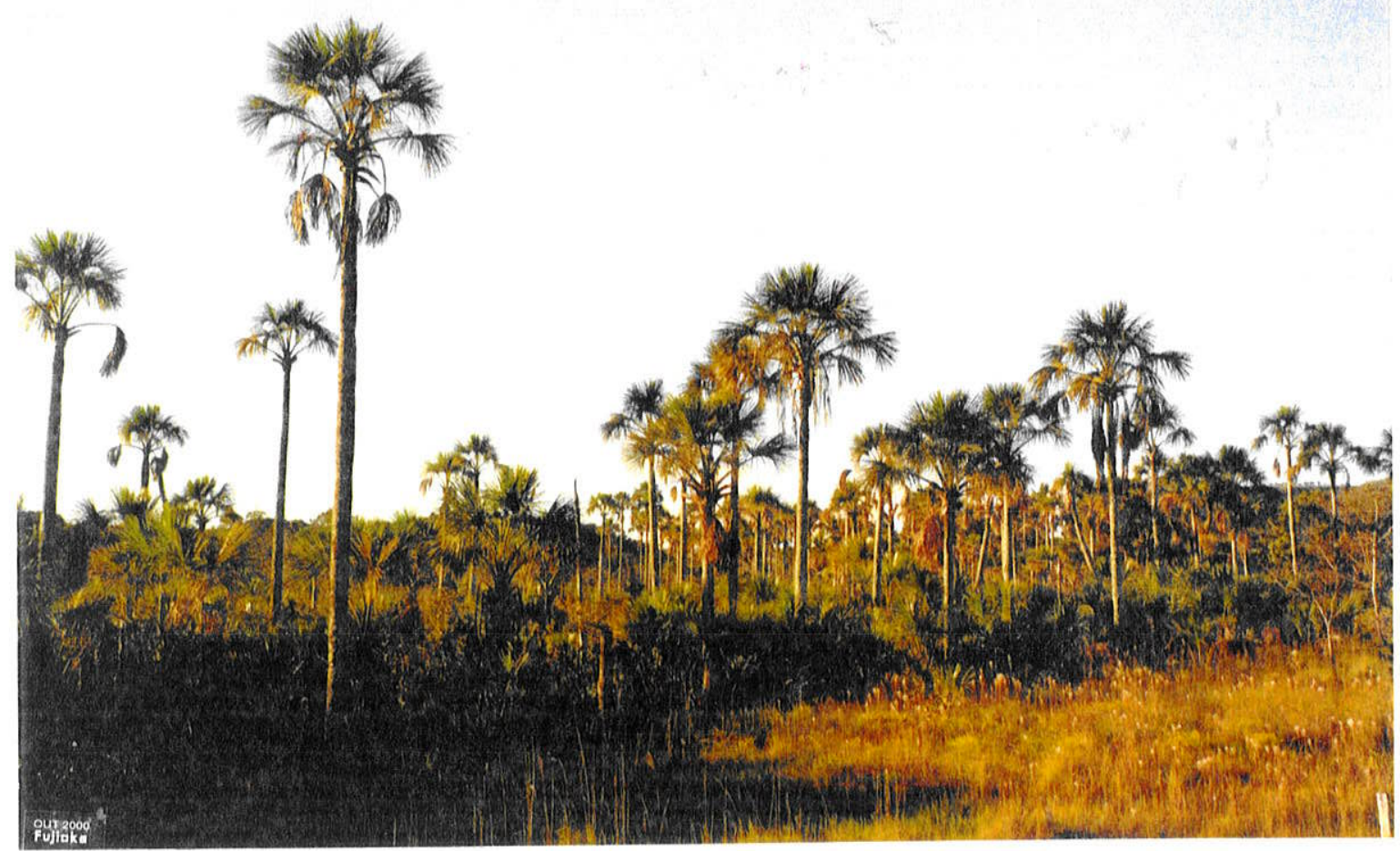

FIGURA 2.18: Aspecto característico da Vereda localizada junto à Lagoa Bonita, DF

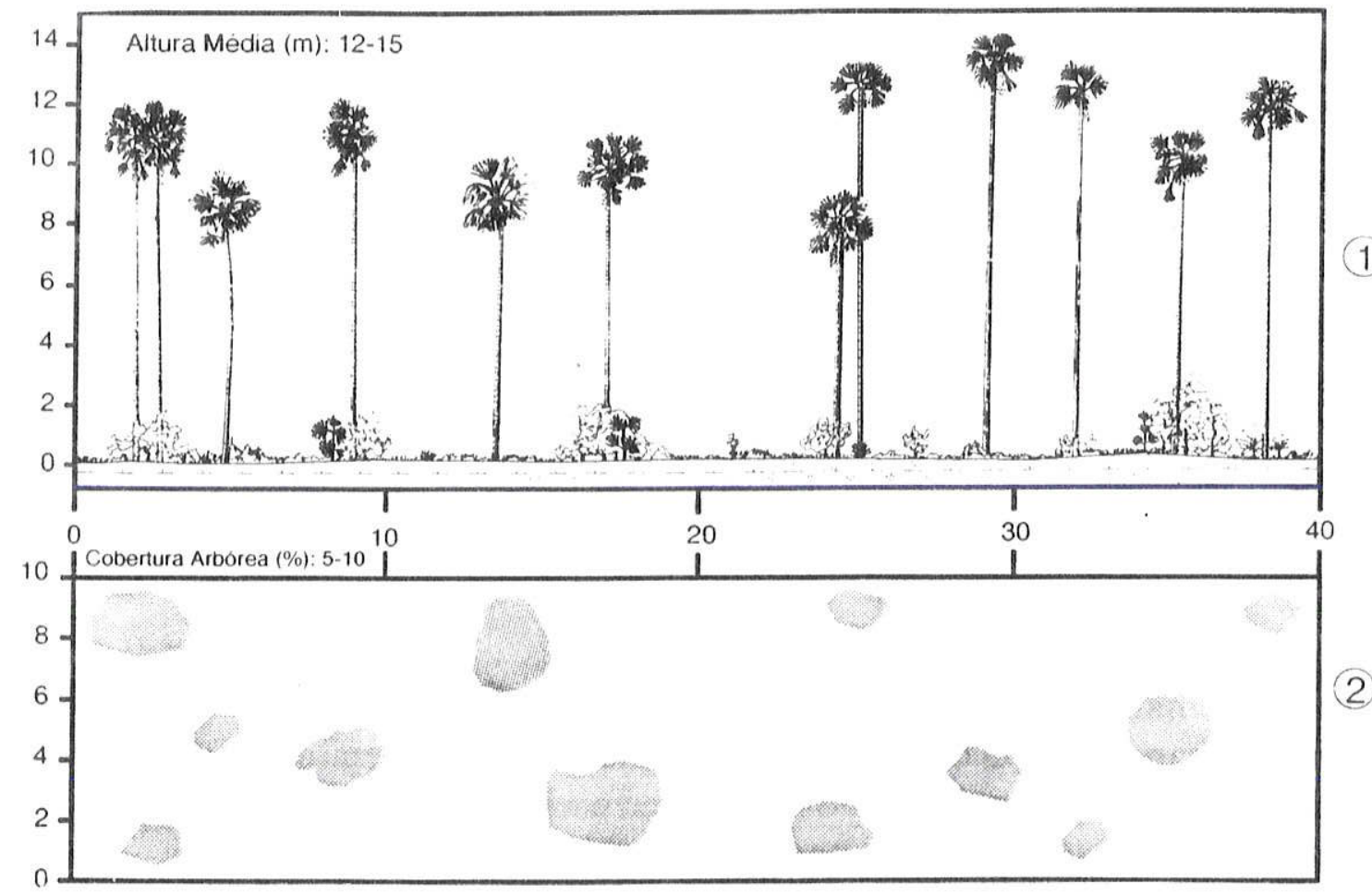

FIGURA 2.19: Diagrama de perfil (1) e cobertura arbórea (2) de uma Vereda representando uma faixa de $40 \mathrm{~m}$ de comprimento por $10 \mathrm{~m}$ de largura (Fonte: Ribeiro \& Walter, 1998) 


\section{METODOLOGIA}

Para a compreensão das mudanças paleoambientais ocorridas na área objeto de estudo, a escolha da metodologia procurou levar em consideração o caráter interdisciplinar do trabalho proposto. Embora os dados básicos sejam fornecidos pela análise palinológica, análise de minerais por difratometria de raios $X$ e dataçōes radiocarbônicas, foram também efetuadas.

A caracterização dos parâmetros bióticos e abióticos, atuais da região, foi baseada em levantamento bibliográfico e em reconhecimento de campo.

Com este enfoque, a metodologia empregada incluiu uma série de procedimentos, que compreenderam atividades de campo e de laboratório.

\subsection{Atividades de campo}

As atividades de campo visaram a coleta de um testemunho de sondagem dos sedimentos da Lagoa Bonita, situada na Reserva Biológica de Águas Emendadas (DF), sobre o qual foram executadas as análises propostas.

A coleta foi efetuada pela equipe coordenada pelo $\mathrm{Dr}$. Kenitiro Suguio no âmbito do projeto desenvolvido pela ORSTOM (Institut de Recherche Scientifique pour le Développement en Cooperation), atual IRD (Institut de Recherche pour le Développement) em colaboração com o CNPq (Conselho Nacional de Desenvolvimento Científico e Tecnológico), com a finalidade de avaliar os climas do passado, através dos espectros polínicos para a reconstituição da paleovegetação e suas alterações, durante o Quaternário tardio.

A sondagem foi realizada na porção central da Lagoa Bonita, com um vibrotestemunhador leve, adaptado por Martin \& Flexor (1989).

A sonda é formada por um vibrador, utilizado em construção civil, conectado a um motor "Montegomery" de 3,4 HP, 3.600 RPM e ca. 1.000 vibraçōes por minuto. Para a utilização em lagoas dispōem-se de uma plataforma flutuante desmontável, sobre a qual é montada um tripé composto por dois perfis de aluminio rigidos e uma escada. Este conjunto é preso na extremidade superior 
por uma peça de junção, com moitão, cadernal e cabo, denominada talha, cuja função é auxiliar a retirada do testemunho de sondagem.

Após a montagem da estrutura de suporte, o vibrador é fixado através de uma braçadeira, a uma das extremidades de um tubo de alumínio de amostragem, com $7,5 \mathrm{~cm}$ de diâmetro interno e $6 \mathrm{~m}$ de comprimento. $O$ tubo é posicionado no topo do tripé, até atingir a posição vertical e, a partir daí, com o auxilio do vibrador, penetra no sedimento, preservando a seqüência $e$ as estruturas sedimentares presentes.

Como o testemunhador destina-se a sedimento inconsolidado, ao atingir material mais compacto, na base dos sedimentos lacustres, cessa a penetração. A retirada do tubo é feita com o auxilio da talha, após a vedação da extremidade superior, evitando assim que o sedimento seja perdido pela extremidade inferior. Após a retirada, a extremidade inferior é também vedada e o testemunho é encaminhado ao laboratório.

Na Lagoa Bonita foram obtidos dois testemunhos, um dos quais, com 360 centímetros de comprimento, identificado com a sigla LBB2, foi utilizado para a análise palinológica, análise dos minerais de argila e datações radiocarbônicas, sendo encaminhado ao Laboratório de Paleoecologia do Instituto de Geociências da Universidade de Brasília.

Duas amostras de sedimentos superficiais, com boas condiçōes de preservação de palinomorfos foram coletadas no entorno da lagoa. Estas amostras, identificadas com as siglas LB-S1 e LB-S2, juntamente com as amostras de superficie da área vizinha analisada da Vereda de Águas Emendadas (Barberi, 1994), identificadas com as siglas AE-S3 e AE-S4, permitiram estabelecer o conjunto esporopolinico atual, comparando-o com os conjuntos registrados ao longo do testemunho estudado. Os histogramas com os registros do conjunto polínico atual, incluindo as quatro amostras de superficie citadas, encontram-se no capítulo 4.

\subsection{Atividades de Laboratório}

As atividades de laboratório, relacionadas à preparaçäo e parte das análises do sedimento, foram executadas no Instituto de Geociências da 
Universidade de Brasilia. A análise microscópica foi realizada no Laboratório de Paleoecologia da Universidade Católica de Goiás.

Inicialmente, o tubo com sedimento foi cortado em segmentos de $1 \mathrm{~m}$ de comprimento e aberto longitudinalmente com o auxilio de uma serra elétrica circular, procurando preservar todas as feiçōes da sedimentaçăo. $O$ testemunho foi descrito macroscopicamente quanto à natureza do sedimento, granulometria, cor, tipos de contato, grau de compactação e presença ou não de matéria orgânica.

Nove amostras de sedimentos foram selecionadas e enviadas ao IRD (França) para datação por Carbono $14\left({ }^{14} \mathrm{C}\right)$, através da Universidade de Brasilia. Em seguida, o testemunho foi amostrado visando análises mineralógica e palinológica. Os pontos amostrais das análises mineralógica, palinológica e de datação radiocarbônica estão indicados na figura 3.1.

\subsubsection{Análise Mineralógica}

Como produto de alteração de rochas, os solos podem conter minerais herdados transformados ou neoformados, dependendo da natureza e tempo de atuação dos processos de intemperismo. Os solos mais maturos são constituídos predominantemente por argilominerais, além de quartzo, óxidos e hidróxidos principalmente de ferro e aluminio, no caso de solos lateríticos.

Um dos métodos utilizados na análise do conteúdo mineralógico é a difratometria de raios- $X$, onde a identificação é feita com base principalmente na estrutura cristalina e na composição química dos mesmos (Brown, apud Alves, 1987).

Nos difratogramas resultantes, os minerais com estrutura cristalina bem definida como o quartzo, são evidenciados por picos bem definidos, estreitos e simétricos, enquanto particulas mal cristalizadas apresentam picos pouco intensos e largos. $O$ registro dos principais argilominerais presentes é marcado por picos característicos, onde o da caolinita ocorre em tomo de $7 \AA$ e $3,5 \AA$ e o da ilita em torno de $10 \AA$ com picos estreitos e simétricos (Guimarāes, 1999).

Neste tipo de análise, a intensidade ou altura do pico característico de um mineral não representa a sua proporção na amostra, já que o mesmo é 
condicionado principalmente pelo grau de cristalinidade e pela quantidade de planos que refletem a radiação e não pela proporção em que o mineral ocorre no sedimento (Besoain apud Guimarães, 1997).

A análise difratométrica envolve a coleta ou seleção de amostras, no caso de testemunhos de sondagem, a preparação do material de acordo com as técnicas convencionais de tratamento de amostras apresentadas por Alves (1987) e a interpretação do difratograma gerado, visando a identificação dos argilominerais.

As análises foram realizadas no Laboratório de raios- $X$ do Instituto de Geociências da Universidade de Brasilia, com a utilização de um difratômetro RIGAKU-GEIGER-FLEX, modelo D/MA - 2AVC, operando com tubo de cobre, com $40 \mathrm{KV}$ e $20 \mathrm{~mA}$.

Nos difratogramas resultantes, a identificação dos minerais foi feita por meio do software Jade 3.0, que dispõe de rotinas de suavização de curva, eliminação de ruido de fundo (background), procura automática de picos, cálculo da largura a meiamaltura, tamanho médio de particulas e pesquisa de possiveis minerais no banco de dados mineralógicos do International Centre for Diffraction Data (ICDD) (Guimarães, 1999).

Foram selecionados quatorze pontos amostrais ao longo do testemunho, indicados na figura 3.1. A seleção das amostras partiu da observação macroscópica, procurando contemplar as diferentes camadas identificadas na descrição do testemunho. Os difratogramas obtidos constituem o Apêndice A.

\subsubsection{Análise Palinológica}

\subsubsection{Fundamentos}

A metodologia para a interpretação paleoecológica, a partir da análise palinológica, fundamenta-se no fato de que todos os tipos polínicos conservados em sedimentos do Quaternário tardio são suscetiveis de comparação com gêneros modernos, uma vez que não ocorreram extinções de plantas.

A designação análise palinológica ou palinologia, foi introduzida por Hyde e Williams em 1944 (Punt et al., 1994) e refere-se ao estudo do conjunto de 
palinomorfos dispersados, através da identificação e contagem de microfósseis com dimensões da ordem de até $150 \mu \mathrm{m}$, incluindo o pólen das plantas superiores, os esporos de Pteridófitas e cistos de algas encontrados em sedimentos, ou em outros contextos.

A paleoecologia, como uma disciplina de interface entre a biologia e a geologia, tem suas interpretações baseadas em principios e conhecimentos advindos dessas duas áreas.

O objeto de estudo da paleoecologia consiste no ecossistema dinâmico, que representa a interação entre os meios físico e biológico, levando em consideração as mudanças que ocorreram e que provocaram modificaçōes nas interrelaçōes ao longo do tempo geológico (Salgado-Labouriau, 1994).

A composição e distribuição da vegetação está diretamente relacionada ao tipo de solo e ao clima (Faegri \& Iversen, 1950; Faegri et al., 1989). Como a dispersão se dá através de esporos (Criptógamas) e sementes (Fanerógamas), quando o ambiente se torna desfavorável, a migração da vegetação ocorre na geração seguinte. A planta-mãe definha e morre, fornecendo um registro das diferentes comunidades de plantas que se sucederam, em resposta às variações climáticas. (Salgado-Labouriau, 1994).

Os palinomorfos são produzidos em grande quantidade e dispersos a grandes distâncias pelas correntes de ar ascendentes, o que possibilita uma boa representatividade tanto da vegetação local como da regional, além de tratamento estatístico dos dados (Faegri \& Iversen, 1950; Faegri et al., 1989; Moore \& Webb, 1978).

Os grãos de pólen das Gymnospermas e Angiospermas, e os esporos de Pteridófitas apresentam um envoltório externo, a exina, constituída de esporopolenina, que é elástica e tem grande resistência ao ataque por agentes químicos redutores, possibilitando a preservação dos grãos quando depositados em ambientes redutores, como lagoas e turfeiras (Salgado-Labouriau, 1984).

Apresentam também caracteristicas morfológicas próprias como formas, dimensões, ornamentações e aberturas características que permitem sua classificação em grupos taxonômicos distintos. 


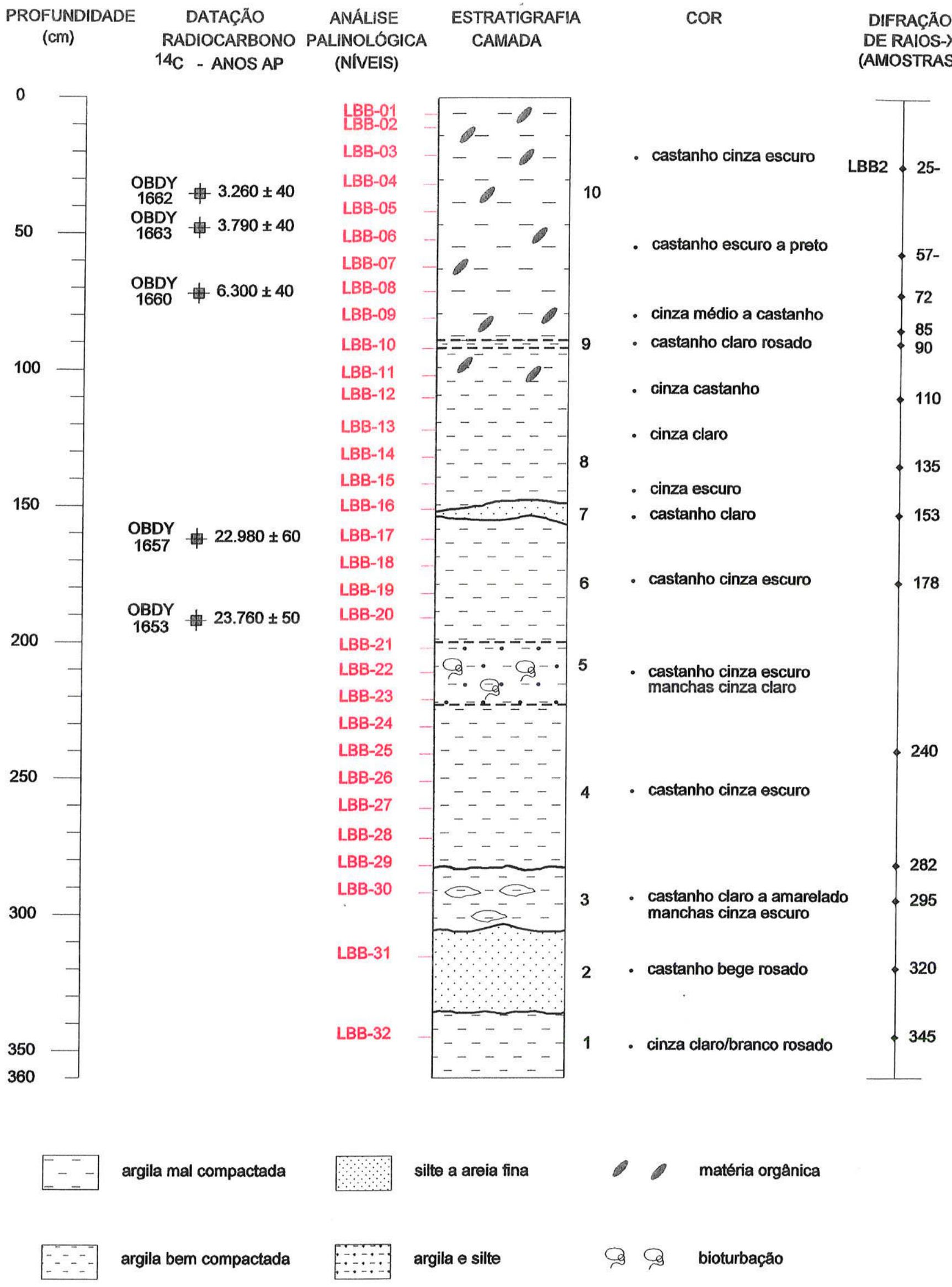

FIGURA 3.1: Estratigrafia e indicação das amostras para datação radiocarbônica, análises palinológica e mineralógica do testemunho da Lagoa Bonita 


\subsubsection{Preparação do sedimento}

Os grãos de pólen, esporos de Pteridófitas e os outros palinomorfos contidos nos sedimentos de lagoas, turfeiras ou rochas sedimentares, estão normalmente diluídos na matriz. As técnicas destinadas à preparação do sedimento para análise palinológica têm por objetivo concentrar os palinomorfos contidos em cada nível, para que seja possivel identificá-los e contá-los, eliminando a maior quantidade possivel de elementos minerais e outros restos orgânicos.

A seqüência de procedimentos, que envolve tratamentos fisicos e quimicos do sedimento, pode variar de acordo com o material analisado e/ou o objetivo da análise. Neste caso, a técnica palinológica empregada compreendeu os procedimentos propostos por Salgado-Labouriau (1973; 1980), SalgadoLabouriau \& Schubert, (1977), Salgado-Labouriau et al. (1977), SalgadoLabouriau \& Rull (1986), Faegri \& Iversen (1950), Faegri et al., 1989; Moore \& Webb (1978), De Oliveira (1992), para sedimentos lacustres do Quaternário, cuja padronização foi sintetizada por Ybert et al. (1992).

Para a análise palinológica do sedimento da Lagoa Bonita, foram extraídas sub-amostras do testemunho, em seqüência estratigráfica de cima para baixo, com a primeira amostra retirada entre 5 e $6 \mathrm{~cm}$ de profundidade, a segunda entre 10 e $11 \mathrm{~cm}$ e as seguintes sucessivamente a intervalos regulares de $10 \mathrm{~cm}$.

As amostras foram numeradas a partir do topo rumo à base com a sigla LBB (Lagoa Bonita, Brasília). Os três últimos niveis amostrados correspondem a intervalos maiores que $10 \mathrm{~cm}$, pois representam camadas onde não há evidências de matéria orgânica, portanto são estéreis em palinomorfos. A localização dos niveis amostrados encontra-se representada na figura 3.1.

O volume a ser amostrado pode variar de acordo com a constituição do sedimento e com o teor de matéria orgânica. Neste caso, o volume amostrado para cada nivel foi de $1 \mathrm{~cm}^{3}$, à exceção do nivel LBB-10 de onde foram retirados $2 \mathrm{~cm}^{3}$ devido à aparente escassez em matéria orgânica.

A partir da retirada das sub-amostras, os procedimentos de laboratório compreenderam as seguintes etapas: 


\section{Introdução de pólen exótico Kochia scoparia}

A técnica de introdução de um marcador exótico permite o cálculo do número absoluto de grãos de cada tipo, por centimetro cúbico de sedimento, independente dos outros tipos. Este procedimento evita distorções nas curvas em casos de super ou de sub-representação de palinomorfos, situações que não são detectadas quando os dados são representados nas curvas de porcentagem em relação à soma total de pólen. A técnica foi estabelecida por Benninghoff (apud Ferraz-Vicentini, 1999), passando por diversas modificações e adaptaçōes no decorrer dos anos.

Posteriormente, Salgado-Labouriau \& Rull (1986) determinaram o número preciso de grãos de Kochia scoparia (Chenopodiaceae) contido em $1 \mathrm{mg}$ de pólen, para seu uso como marcador interno. Obtido o valor de $60.543,88$ grãos por miligrama, pode-se introduzir no sedimento a ser analisado, antes das preparações quimicas, a quantidade em peso que se desejar deste pólen exótico. Embora as Chenopodiaceae ocorram no Brasil, estão muito mal representadas (July, 1979) e o pólen de Kochia scoparia é facilmente identificado.

Ao sedimento de cada nivel e das amostras de superfície foi adicionado ca. 0,60 a $1,0 \mathrm{mg}$ do pólen exótico, anteriormente a qualquer tratamento para que este marcador estivesse também submetido a todas as etapas pelas quais passaram os palinomorfos, inclusive com possiveis perdas.

\section{Técnica de hidróxido de potássio a 10\% (KOH-10\%)}

Foi elaborada por von Post (1967) e destina-se à análise palinológica de turfeiras, tendo como objetivo eliminar o ácido húmico e parte da matéria orgânica.

A cada amostra foram adicionados em torno de $5 \mathrm{ml}$ de $\mathrm{KOH} 10 \%$ sendo fervido por cerca de 5 minutos. A seguir, o sedimento foi lavado com água destilada até atingir o $\mathrm{pH}$ neutro. Por lavar o sedimento, entendem-se sucessivas centrifugaçōes e decantações do sobrenadante.

\section{Tamisação}

Tem por objetivo separar macrorrestos para estudos posteriores. 0 sedimento contido nos tubos de ensaio foi passado uma tela fina de náilon, que 
funciona como um tamis. A tela foi colocada sobre um funil de vidro, retendo os macrorrestos e permitindo a passagem do sedimento e dos palinomorfos.

\section{Acetólise}

Foi idealizada por Erdtman \& Erdtman em 1933 (Erdtman, 1952) e revisada por Erdtman (1960). O método conhecido por acetilação visa tornar a membrana externa do grăo de pólen e esporos, denominada exina, transparente, e destruir a membrana interna, a intina, e o conteúdo celular do pólen fresco de plantas atuais. O processo se dá pela reação do anidrido acético em meio ácido, com a esporopolenina, que constitui a exina.

A mistura de acetólise é constituida de uma parte de ácido sulfúrico e nove partes de anidrido acético. Foi adicionada ao material, após a desidratação do mesmo por ácido acético glacial, uma vez que a mistura é altamente reativa com água. $O$ sedimento com a mistura de acetólise foi fervido por 5 minutos em banho-maria. A seguir foi centrifugado, decantado, lavado em ácido acético glacial, e posteriormente em água destilada.

\section{Técnica do ácido clorídrico a $10 \%(\mathrm{HCl}-10 \%)$}

Foi proposta por Faegri \& Iversen (1950) e tem por objetivo a eliminação de carbonatos. Na presença destes, ao se adicionar $\mathrm{HCl}$ a $10 \%$ até o dobro do volume da amostra, ocorrerá a dissolução dos carbonatos com desprendimento de $\mathrm{CO}^{2}$. Não ocorrendo carbonatos, como no sedimento da Lagoa Bonita, o material foi transferido com água destilada para tubos de plástico, para a realização da etapa seguinte.

\section{Técnica do ácido fluoridrico a $40 \%$ (HF-40\%)}

Foi introduzida por Assarson e Granlund em 1924 (Faegri \& Iversen, 1950) e tem por objetivo eliminar minerais de silica e de silicatos. Adicionaram-se ao sedimento cerca de $5 \mathrm{ml}$ de HF a $40 \%$ e ferveu-se por 15 minutos em banhomaria. A seguir, o material foi transferido para béqueres de plástico e deixado em repouso por uma noite.

A finalização do processo se deu com a lavagem do material uma vez em $\mathrm{HCl}$ para eliminar os fluoratos que eventualmente tenham se formado, e 
posteriormente com água destilada até alcançar pH neutro. $\mathrm{O}$ material foi então transferido para os tubos de vidro ou de plástico onde foi acondicionado em meios de montagem.

\section{Mejo de montagem}

Com a finalização dos procedimentos anteriores, passaram a predominar nas amostras os palinomorfos, que foram incluídos em um meio de montagem. A escolha do meio de montagem é feita em função das diferenças de viscosidade e da resposta dos palinomorfos ao material utilizado. Como os palinomorfos são incluidos em um meio de montagem que permita a observação sob microscópio ótico, este deve ter um índice de refração semelhante ao do vidro (lâmina e lamínula)

O óleo de silicone, um dos materiais normalmente utilizado, é altamente viscoso, permite girar mais facilmente os palinomorfos que, neste meio, apresentam-se mais contraidos (Andersen, 1960). O glicerol PA, outro meio de montagem utilizado com freqüência em estudos palinológicos, é menos viscoso, e deixa os gräos mais inchados.

Neste trabalho, utilizou-se o óleo de silicone nas preparações dos 15 primeiros niveis, enquanto era necessário uma maior mobilidade dos grãos para a montagem do catálogo de tipos, onde consta a descrição e o desenho de cada palinomorfo. Nos demais niveis utilizou-se o glicerol, que é um material que permite reprocessamento da amostra em caso de necessidade.

\subsubsection{Análise do material ao microscópio}

A identificação do pólen, dos esporos de Pteridófitas, algas microscópicas e outros palinomorfos contidos em sedimentos do Quaternário tardio é feita por comparação com seus equivalentes modernos, buscando chegar à categoria taxonômica mais baixa possivel, de espécie, porém freqüentemente não se alcança mais que o nivel de família ou de gênero (Salgado-Labouriau , 1984).

Para se definir um tipo polinico que pode representar um gênero, ou mesmo uma familia, baseia-se em uma série de caracteristicas do grão como número de aberturas, tipos de abertura, ornamentação da exina, posição da 
abertura, forma e dimensão, atendo-se sempre ao fato de maior ou menor variabilidade dentro do tipo polínico ou esporo de uma espécie (SalgadoLabouriau, 1973; Anderson et al., 1993).

Inicialmente foi montado um catálogo onde cada tipo polínico foi descrito, desenhado e numerado a partir de 1001. Cada ficha foi complementada, após a identificação do tipo, com dados referentes ao hábito e ambiente de ocorrência, a partir dos trabalhos de levantamentos florísticos executados em áreas de ocorrência de cerrado (Pereira et al., 1990; Ratter, 1991; Filgueiras \& Pereira,1994; Ribeiro \& Walter, 1998; Mendonça et al.,1998;).

Os esporos de Pteridófitas foram incluídos no catálogo geral e as algas constituíram um catálogo à parte cuja numeração foi iniciada em 2001. Alguns tipos foram posteriormente fotografados, constituindo o Anexo 01.

Para a identificação dos tipos foram utilizadas lâminas de referência (coleção particular de M.L.Salgado-Labouriau), chaves de identificação, catálogos, artigos e livros com descrições de tipos polínicos já estabelecidos e estudados. Os principais textos apresentam normalmente uma descrição detalhada, além de desenhos e fotografias dos tipos.

Os textos utilizados compreendem Erdtman (1952), Heusser (1971), Salgado-Labouriau (1973), Murillo \& Bless $(1974,1978)$, Markgraf \& D'Antoni (1978), Hooghiemstra (1984), Roubik \& Moreno (1991), Salgado-Labouriau et al. (1992), De Oliveira (1992), Ferraz-Vicentini (1999).

Foram contados todos os tipos polínicos: os esporos de Pteridófitas, algas microscópicas, esporos de fungos e outros palinomorfos identificados também através dos trabalhos de Joly (1963), Van Geel (1976), Van Gell \& Van der Hammen (1978) e Hooghiemstra (1984). Além de palinomorfos, foram contados em lâmina à parte, a quantidade de partículas de carvão em cada nivel, em relação ao pólen exótico.

A contagem dos palinomorfos foi feita de modo que não ocorresse seleção involuntária do analista, nem contagem repetida do mesmo palinomorfo. $\mathrm{Na}$ montagem das lâminas para a leitura, foi necessário homogeneizar a amostra, evitando que grãos pesados ficassem decantados no fundo do tubo provocando uma amostragem viciada. Uma alíquota do sedimento e uma gota de óleo de 
silicone ou de glicerina foram colocados sobre uma lâmina, misturados e recobertos por uma lamínula.

As lâminas preparadas foram levadas ao microscópio óptico para a leitura com uma objetiva de 40X, lidas no sentido vertical, com espaçamento entre as colunas verticais de no mínimo três vezes o campo visual, para evitar a recontagem de um mesmo grāo. Foram contados todos os palinomorfos e o pólen exótico.

Para cada nivel foram lidas no mínimo cinco lâminas e no minimo 300 grãos de pólen e esporos de Pteridófitas, de acordo com Ybert et al. (1992). O número máximo de grãos, que determinava a interrupção da leitura foi estabelecido a partir da curva de saturação (Salgado-Labouriau et al., 1977; Salgado-Labouriau, 1980).

A curva de saturação foi montada relacionando-se o número de tipos obtidos até um determinado momento, à soma total de grãos obtidos. Para cada nivel foram montadas duas ou três curvas de saturação, uma incluindo todos os tipos, outra excluindo as gramíneas e eventualmente Isoëtes, pois a superrepresentação dos mesmos poderia saturar a curva antes de se obter uma boa representação do conjunto.

Neste trabalho considerou-se saturada a curva de um determinado nivel, quando foram contados cerca de 70 grãos entre pólen (excluindo as gramíneas e eventualmente /soëtes) e esporos de Pteridófitas, sem que ocorresse nenhum tipo novo. As curvas de saturação dos niveis 9 e 20, exemplificando os procedimentos são apresentadas na figura 3.2 .

\subsubsection{Organização dos dados}

A partir da identificação, cadastro e contagem dos grãos, os dados foram organizados em tabelas móveis correlacionáveis, preparadas em um programa desenvolvido no Excel (Windows 98), visando a elaboração de gráficos baseados na porcentagem e na concentração de cada palinomorfo identificado. Foram montadas três tabelas $(3.1,3.2,3.3)$ que constituem respectivamente os anexos 2,3 e 4 . 
A primeira tabela (3.1 - Anexo 2), relaciona todos os tipos, numerados a partir de 1001, indicando a identificação botânica, a família, o hábito, a formação vegetacional, que indica o ambiente, e a fonte dos dados. No caso da fonte atual foram utilizados os textos que apresentam levantamentos detalhados da flora dos cerrados em áreas próximas desta pesquisa.

No caso da fonte estar relacionada ao pólen, foi utilizado o texto de Marchant et al. (em preparação), que apresenta a relação dos tipos polínicos da América Latina e sua indicação ecológica. A tabela 3.1 pode ser organizada em ordem numérica de tipos, em ordem alfabética, por familia, por hábito, ou por formação, permitindo assim uma ordenação mais eficiente dos dados a serem utilizados na elaboração de gráficos.

A segunda tabela integrada (3.2 - Anexo 3) relaciona as variáveis físicas e biológicas (volume de sedimento, peso de sedimento e peso de Kochia scoparia introduzida) utilizadas para o cálculo da concentração de cada grāo por nivel, permitindo um controle maior em situaçōes onde ocorre sub-representação ou super-representação de algum tipo.

Os dados de concentração resultam da adição ao material de cada nivel de uma quantidade conhecida de Kochia scoparia, ụma espécie exótica na região em estudo e, da qual se conhece a relação entre a quantidade de grãos e o peso, cujo valor de $60.543,88$ grãos/mg foi calculado por Salgado-Labouriau \& Rull (1986).

Com este dado, pode-se calcular o número de grãos de pólen exótico introduzido em cada nivel e conseqüentemente o número absoluto de grãos de cada tipo identificado, em cada nivel, a partir das seguintes relaçōes:

Para cada nivel:

$\mathrm{N}^{\circ}$ de Kochia introduzida $=60.543,88 \times$ Peso de Kochia introduzida $(\mathrm{mg})=\mathrm{KI}$

Concentração do Tipo $Y=\frac{N^{\circ} \text { gräos do tipo } Y \times K \mathrm{Kl}}{N^{\circ} \text { grãos de Kochia contados }(\mathrm{KC})} \times \frac{1}{\mathrm{~cm}^{3} \text { sedimento }}$ 
O preenchimento da tabela 3.2 gera automaticamente uma constante denominada de Beta, que foi transferida para a tabela 3.3 (Anexo 4) e utilizada no cálculo da concentração de cada tipo.

A tabela 3.3 apresenta o número total de pólen de cada nivel e o número de grãos de cada tipo identificado. Como as tabelas são articuladas, a medida que se efetuava a leitura de um determinado nivel e se preenchia a tabela, os dados relativos à porcentagem e à concentração de cada tipo foram calculados automaticamente.

\subsubsection{Apresentação dos diagramas de palinomorfos}

A representação do conteúdo de palinomorfos de uma seqüência estratigráfica é normalmente feita na forma de diagramas de porcentagem e de concentração.

Os diagramas de porcentagem ressaltam mudanças de um tipo de vegetação para outro no decorrer do tempo geológico, caracterizando as mudanças relativas no conjunto, porém não informam quanto à abundância independente de cada elemento, podendo apresentar distorções na curva, principalmente quando a soma total de pólen cai acentuadamente, como em niveis quase estéreis (Davis, 1966; Salgado-Labouriau, 1979; Salgado-Labouriau et al., 1988).

Os diagramas de concentração mostram a presença e a abundância de cada tipo em valores absolutos. Esta representação baseia-se na adição do pólen exótico de Kochia scoparia (Salgado-Labouriau \& Rull, 1986) descrita no item 3.2.2.4.

Os diagramas de palinomorfos apresentados no capitulo 4 foram elaborados com a utilização do programa de computador Tilia e Tiliagraph (Grimm, 1987). Os diagramas de porcentagem relacionam o número de grãos de um determinado tipo com a "soma de pólen" que corresponde ao número total de grãos de pólen, presentes naquele nivel e ao qual se atribui o valor 100.

Todos os diagramas de porcentagem apresentam uma coluna na extremidade direita onde estão indicados estes valores. Os diagramas de 
concentração apresentam a concentração de cada tipo em grãos $/ \mathrm{cm}^{3}$ de sedimento, independente dos valores de outros tipos.

Na montagem dos diagramas, os palinomorfos podem ser representados individualmente ou agrupados de acordo com o tipo de hábito, de vegetação, etc. A seleção dos tipos polínicos, reunidos em cada ambiente ou formação botânica, foi baseada nos levantamentos florísticos realizados nas áreas próximas a esta pesquisa.

Os elementos que apresentaram porcentagem e concentração menores que a escala de cada diagrama ou histograma, foram somados com outros tipos que apresentam mesmo hábito e ocorrência no mesmo ambiente.

Nos diagramas também estão representados os esporos de Pteridófitas, as algas, os fungos, e os tipos polínicos indistintos dos quais quatro encontram-se individualizados, pois ocorrem com freqüência e em quantidades significativas. Tipos indistintos, de ocorrência esporádica e em pequena quantidade, foram reunidos em um único conjunto.

A distribuição dos tipos incluídos em cada conjunto foi baseada nos trabalhos de Pereira et al. (1990), Ratter (1991), Lorenzi, (1992; 1998); Filgueiras \& Pereira (1994), Mendonça et al. (1998) e Ribeiro \& Walter (1998). Algumas familias de importância no contexto da vegetação dos cerrados que apresentam aspectos peculiares foram separadas em uma categoria denominada de Outros elementos, que compreende Compositae, Euphorbiaceae outras e Gramineae.

As Compositae embora apresentem o maior número de gêneros com hábito herbáceo, possuem também registro de espécies arbóreas, como Piptocarpha rotundifolia e Wunderlichia mirabilis com referência de ocorrência em áreas dos cerrados (Pereira et al., 1990). As Gramineae compreendem predominantemente elementos herbáceos, porém não é possivel distinguir entre as terrestres e aquelas de hábito aquático. Euphorbiaceae outras, compreende elementos que apresentam tanto hábitos arbóreo como herbáceo e uma ampla distribuição.

A distribuição dos palinomorfos em grupos com afinidades ecológicas compreende as seguintes categorias descritas: 


\section{Elementos palustres:}

Alismataceae, Cyperaceae, Mauritia, Myriophyllum, Outras ervas palustres (Drosera, Typha e Utricularia), Pontederiaceae/Xyridaceae, Umbeliferae.

\section{Elementos arbóreos de mata:}

Antonia ovata, Copaifera, Cunnoniaceae, Cupania, Hedyosmum, Ilex, Neea, Outras árvores da mata (Agonandra, Dyospirus, Emmotum, Eriotheca, Euplassa, Lafoensia, Plenckia, Roupala, Salacia, Sapium e Styrax), Podocarpus, Rapanea, Symplocos e Trema.

\section{Elementos arbóreos do cerrado:}

Brosimum, Byrsonima, Curatella, Anacardiaceae (1076, 1124), Outras árvores do cerrado (Andira, Arrabidaea, Couepia, Erythroxylum, Harpalice, Kielmeyera, Pseudobombax, Pterodon, Sclerolobium e Waltheria,) e Stryphnodendron.

\section{Outros elementos arbóreos:}

Melastomataceae/Combretaceae, Myrtaceae, Outras Leguminosae (Tipo 1065), Paimae (exceto Mauritia) e Solanaceae.

\section{Elementos herbáceos:}

Acalypha, Amaranthaceae (Gomphrena, Altemanthera e Pfaffia), Caryophyllaceae, Cuphea, Ericaceae, Eriocaulaceae, Labiatae (Hyptis e Salvia), Mimosa (Mimosa capillipes, Mimosa Tipo A, Calliandra, Mimosa distans, Mimosa Tipo B), outras ervas (Peixotoa, Dorstenia, Stylosanthes, Crotalaria, Crumenaria, Diplusodon, Cassia), Polygalaceae (Bredemeyera tipo A e B), Rubiaceae (Borreria e Richardsonia), Sebastiana e Smilax.

\section{Outros elementos:}

Compositae, Euphorbiaceae outras (Bemardia, Maprounea e Tragia) e Gramineae. 


\section{Trepadeiras:}

Serjania, Trigonia, Aristolochia e Cayaponia.

\section{Indistintos:}

Tipos 1040; 1077; 1087; 1103 e Tipos Raros (1045; 1047; 1060; 1061; $1086 ; 1094 ; 1098 ; 1113 ; 1116 ; 1121 ; 1127 ; 1136 ; 1138 ; 1140 ; 1156 ; 1162 ; 1163$; $1164 ; 1169 ; 1171 ; 1191)$.

\section{Ptoridófitas:}

Alsophila, Cyathea, Isöetes, Lycopodium cemnum, Outros Monoletes (Asplenium, Cheilantes, Pleopeltis, Polypodium, Tipo 1036 e 1135), Outros Triletes (Cheilantes, Dicksonia, Grammites, Jamesonia, Lindsaea, Lycopodium clavatum, Lycopodium curvatum, Polypodium, Selaginella e Tipo 1084; ).

\section{Algas:}

Botriococcus, Chlamydomonas, Mougotia, outras algas (Cosmarium, Debarya, Pediastrum, Tipo 2002 e 2003), Spirogyra e Zygnemataceae.

Para a determinação das ecozonas bioestratigráficas, foi utilizado o programa estatístico CONISS (Grimm, 1987), que compreende análise de agrupamento (cluster analysis), baseada nos 40 taxons mais freqüentes encontrados no testemunho. A relação dos táxons selecionados está representada na figura 3.3 . 

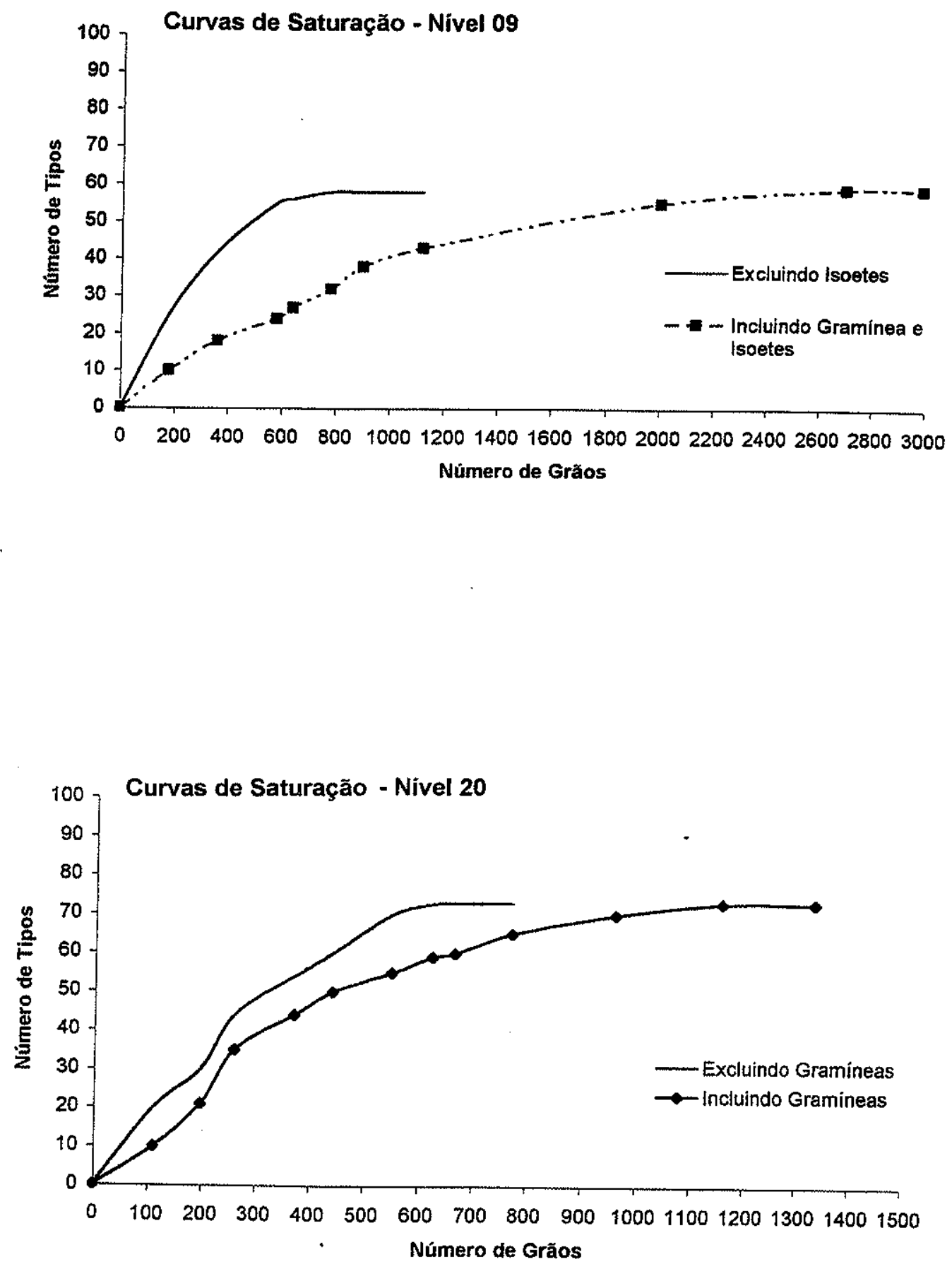

FIGURA 3.2: Exemplos de curvas de saturação dos niveis 9 e 20 


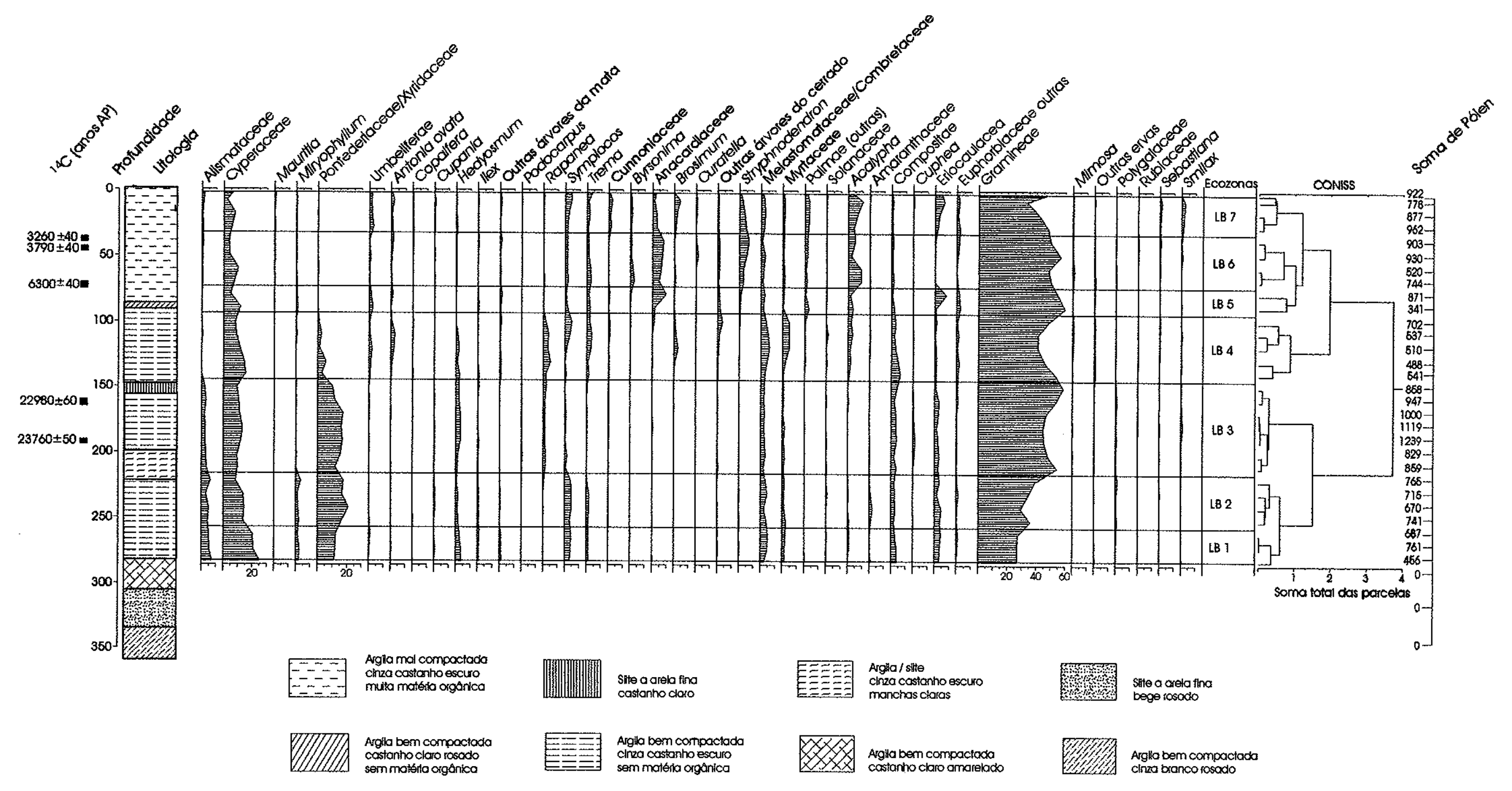

FIGURA 3.3: Indicação dos 40 elementos utilizados para a determinação das ecozonas do sedimento da Lagoa Bonita 


\section{RESULTADOS}

\subsection{Descrição do Testemunho}

O testemunho de sondagem obtido na Lagoa Bonita (DF), representado na figura 4.1, alcançou a profundidade de $360 \mathrm{~cm}$ e apresentou as seguintes camadas descritas de baixo para cima:

\section{Camada 01:}

Intervaio: 336 a $360 \mathrm{~cm}$ de profundidade.

Constituição: Sedimento cinza claro a branco rosado, bem compactado, sem matéria orgânica, constituído basicamente por argila.

\section{Camada 02:}

Intervalo: 306 a $336 \mathrm{~cm}$ de profundidade.

Constituição: Sedimento castanho bege rosado, sem matéria orgânica, constituído de silte a areia fina. Apresenta contato irregular interdigitado com as camadas superior e inferior.

\section{Camada 03:}

Intervalo: 283 a $306 \mathrm{~cm}$ de profundidade.

Constituição: Sedimento castanho claro a amarelado, constituído basicamente por argila, sem matéria orgânica, com manchas de argila cinza escuro, aparentando interdigitação. Apresenta contato irregular, discordante e brusco com a seqüência inferior.

\section{Camada 04:}

Intervalo: 223 a $283 \mathrm{~cm}$ de profundidade.

Constituição: Sedimento castanho cinza escuro, gradando para cinza a preto na base da seqüência, bem compactado, constituido basicamente por argila, com 
matéria orgânica e poucos fragmentos orgânicos bastante alterados. Apresenta contato nítido, irregular e discordante com a seqüência inferior.

\section{Camada 05:}

Intervalo: 200 a $223 \mathrm{~cm}$ de profundidade.

Constituição: Sedimento castanho cinza escuro, bem compactado, constituído de argila a silte, com matéria orgânica, aparentemente sem fragmentos vegetais. Apresenta manchas de forma irregular de coloração cinza clara, representando provável bioturbação. $O$ contato com a seqüência inferior apresenta-se gradativo.

\section{Camada 06:}

Intervalo: 157 a $200 \mathrm{~cm}$ de profundidade.

Constituiçăo: Sedimento castanho cinza escuro, bem compactado, homogêneo, constituido basicamente de argila, com matéria orgânica, sem fragmentos vegetais. $O$ contato com a seqüência inferior apresenta-se gradativo.

\section{Camada 07:}

Intervalo: 149 a $157 \mathrm{~cm}$ de profundidade.

Constituição: Sedimento castanho claro, bem compactado, constituído basicamente por silte a areia fina, sem matéria orgânica. $O$ contato com a seqüência inferior apresenta-se brusco, irregular e erosivo.

\section{Camada 08:}

Intervalo: 92 a $149 \mathrm{~cm}$ de profundidade.

Constituição: Sedimento cinza, bem compactado, constituido por argila com matéria orgânica e pequena quantidade de fragmentos vegetais finos. A partir de $124 \mathrm{~cm}$ ocorre um contato difuso com relação à cor e o sedimento passa a apresentar uma coloração cinza clara até $141 \mathrm{~cm}$, a partir de onde volta a ocorrer uma coloração cinza escuro até o contato com a camada inferior. $O$ contato com a sequuência inferior apresenta-se brusco, irregular e erosivo.

\section{Camada 09:}

Intervalo: 89 a $92 \mathrm{~cm}$ de profundidade. 
Constituição: Sedimento castanho claro rosado, que grada para acinzentado na base, compactado, constituido basicamente pela fração argila, sem fragmentos orgânicos. Apresenta contato gradual com relação à cor e ao conteúdo em argila com a seqüência inferior.

\section{Camada 10:}

Intervalo: 0 a $89 \mathrm{~cm}$ de profundidade.

Constituição: Sedimento castanho a cinza escuro, mal compactado, constituido basicamente de argila e matéria orgânica com grande quantidade de fragmentos vegetais. A partir de $41 \mathrm{~cm}$, ocorre uma modificação na cor do sedimento o qual passa para castanho escuro a preto até a profundidade de $69 \mathrm{~cm}$, a partir de onde torna-se cinza médio a castanho, até a profundidade de $89 \mathrm{~cm}$. Observa-se aumento na compactação do topo rumo à base do intervalo e diminuição gradativa da quantidade de fragmentos vegetais. Apresenta contato brusco com a seqüência inferior com relação à cor e gradativo em relação ao conteúdo de argila.

Ao longo do testemunho foram retiradas 9 amostras, abrangendo os intervalos 35 a $40 \mathrm{~cm}, 43$ a $48 \mathrm{~cm}, 70$ a $75 \mathrm{~cm}, 160$ a $165 \mathrm{~cm}, 190$ a $195 \mathrm{~cm}, 200$ a $201 \mathrm{~cm}, 220$ a $221 \mathrm{~cm}, 250$ a $251 \mathrm{~cm}$ e 282 a $283 \mathrm{~cm}$, enviadas para datações por carbono 14. Entretanto foram obtidas somente cinco idades, até a profundidade de $195 \mathrm{~cm}$, uma vez que as amostras mais profundas não apresentaram matéria orgânica suficiente.

Para o cálculo da taxa de sedimentação do primeiro intervalo, entre a superfície e a profundidade de $37,5 \mathrm{~cm}$ considerou-se a superfície como o presente para o carbono 14 (1950). As dataçōes obtidas e as taxas de sedimentação para os intervalos amostrados estão indicados na Tabela 4.1.

Embora a delimitação e descrição das camadas tenha se baseado no conteúdo, no grau de compactação e na cor do sedimento, a análise do testemunho permite estabelecer quatro seqüências com características próprias, onde as camadas foram agrupadas e descritas a partir da base do testemunho. 
TABELA 4.1: Datações radiocarbônicas e taxas de sedimentação - Lagoa Bonita,

\begin{tabular}{|c|c|c|c|c|}
\hline AMOSTRA & $\begin{array}{c}\text { POSIÇÃO } \\
\text { PROFUNDIDADE } \\
\text { (CM) } \\
\end{array}$ & $\begin{array}{l}\text { IDADE ANOS } \\
\text { AP }\end{array}$ & ANOS/CM & CM/100 ANOS \\
\hline - & 0 & - & \multirow[t]{2}{*}{86,9} & \multirow[t]{2}{*}{1,2} \\
\hline OBDY 1662 & 35 A 40 & $3.260 \pm 40$ & & \\
\hline OBDY 1663 & 43 A 48 & $3.790 \pm 40$ & 66,3 & 1,5 \\
\hline OBDY 1660 & 70 A 75 & $6.300 \pm 40$ & 92,9 & 1,1 \\
\hline OBDY 1657 & 160 A 165 & $22.980 \pm 60$ & 185,3 & 0,53 \\
\hline OBDY 1653 & 190 A 195 & $23.760 \pm 50$ & 26 & 3,8 \\
\hline
\end{tabular}

A primeira seqüência, basal, compreende as camadas 1,2 e 3 , no intervalo entre $283 \mathrm{~cm}$ e a base do testemunho em $360 \mathrm{~cm}$. Embora ocorra variação na litologia e contatos interdigitados, a característica marcante desta seqüência é a ausência de matéria orgânica no sedimento e um conteúdo mineralógico, que sugerem a ausência de sedimentação lacustre neste intervalo. Esta seqüência ainda não pode ser datada porém é mais antiga que 26.140 anos AP.

A segunda seqüência, posicionada entre $157 \mathrm{~cm}$ e $283 \mathrm{~cm}$ de profundidade, compreende as camadas 4,5 e 6 e caracteriza-se pela predominância de sedimento argiloso, associado à matéria orgânica com pouco a nenhum fragmento vegetal. Embora ocorra intercalação de silte, os contatos são gradativos e a presença de matéria orgânica é constante ao longo de toda a seqüência, cuja base na profundidade de $283 \mathrm{~cm}$ é marcada por um contato erosivo e discordante.

Considerando para toda a seqüência a taxa de sedimentação obtida, a partir das duas idades posicionadas neste intervalo, 22.980 $\pm 60 \mathrm{AP}$ entre $160 \mathrm{e}$ $165 \mathrm{~cm}$ e $23.760 \pm 50$ AP entre 190 e $195 \mathrm{~cm}$, obtém-se para a profundidade de $283 \mathrm{~cm}$, que marca o início da implantação da lagoa, uma idade extrapolada em torno de 26.140 anos AP. 
A terceira seqüência com características próprias, é formada pela camada 7 situada entre 149 e $157 \mathrm{~cm}$ de profundidade, que apresenta uma litologia diferenciada de silte a areia fina, coloração castanho claro e contatos discordantes e erosivos, com relação às seqüências inferior e superior. Para estabelecer o intervalo cronológico desta seqüência que não apresenta datas absolutas e é limitada por contatos erosivos, utilizou-se para o cálculo das idades da base e do topo, as taxas de sedimentação dos intervalos inferiores e superiores respectivamente.

Esta opção justifica-se pelo fato de que embora a seqüência esteja posicionada entre duas datas absolutas $(22.980 \pm 60 \mathrm{em} 162,5 \mathrm{~cm}$ e $6300 \pm 40$ em $72,5 \mathrm{~cm}$ ) que geram uma taxa de sedimentação de $0,53 \mathrm{~cm} / 100$ anos, a utilização deste índice não leva em consideração os contatos discordantes e erosivos que limitam a seqüência 3. Deste modo; a taxa de sedimentação poderia ser maior que a calculada, pois parte do sedimento depositado poderia ter sido erodido.

Desta forma, para a base da seqüência, posicionada em $157 \mathrm{~cm}$ de profundidade, obtém-se a idade extrapolada de cerca de 22.800 anos AP, calculada com a taxa de sedimentação de $3,8 \mathrm{~cm} / 100$ anos do intervalo contínuo imediatamente inferior. Para o topo da seqüência, posicionado em $149 \mathrm{~cm}$ de profundidade, obtém-se a idade extrapolada de cerca de 13.400 anos AP calculada com a taxa de sedimentação de $1,1 \mathrm{~cm} / 100$ anos do intervalo contínuo, imediatamente superior.

A quarta seqüência, superior, compreende o intervalo entre 0 e $149 \mathrm{~cm}$ de profundidade, incluindo as camadas 8, 9 e 10. Embora ocorra modificação de cor na camada 9 , não se observa alteração acentuada na constituição do sedimento e os contatos são gradativos, fato que permite caracterizá-la como seqüência única, predominantemente argilosa, rica em matéria orgânica, com a presença decrescente de fragmentos vegetais e aumento gradativo da compactação do topo rumo à base.

Partindo-se das premissas anteriormente levantadas e utilizando-se para calcular a idade da base desta seqüência a taxa de sedimentação de intervalos continuos, sem indícios de contatos erosivos, obtém-se para a base em $149 \mathrm{~cm}$ de profundidade, a idade extrapolada, já referida de cerca de 13.400 anos AP. 
Neste contexto, considerando-se a continuidade da seqüência 1, com litologia homogênea, contatos gradativos e variações somente na cor do sedimento, a porção intermediária da camada 9 , posicionada em torno de $90 \mathrm{~cm}$ de profundidade, que representa 0 intervalo diferenciado da seqüência, corresponde a uma idade extrapolada de aproximadamente 7.900 anos AP.

\subsection{Análise mineralógica por difração de raios $X$}

Os argilominerais herdados e neoformados, bem como quartzo, óxidos e hidróxidos metálicos são os componentes principais de solos mais maturos, principalmente aqueles formados sob condições de laterização.

A utilização dos argilominerais, presentes em sedimentos e solos, é bastante conhecida na literatura como ferramenta em interpretaçōes paleoambientais, uma vez que a ocorrência e distribuição dos mesmos, principalmente os mais comuns como a ilita, a caolinita e a gibbsita, é controlada pela rocha-mãe, pelo clima e pelo tempo de exposição à alteração.

A ilita é o argilomineral dominante de solos imaturos que estiveram submetidos a um intemperismo químico pequeno, próprio de climas onde é baixa a lixiviação, ou a curto período de exposição, podendo também ser resultante da erosão de rochas-mãe não-alteradas (Suguio, 1980). Constituem os argilominerais predominantes nos metassedimentos do Grupo Paranoá, na unidade psamopelito-carbonatada que ocorre na área de estudo (Guimarães, 1997).

A esmectita, corresponde ao estágio inicial de alteração da ilita. Segundo Weaver (apud Robert \& Kennett, 1994), a esmectita pode se formar em áreas tropicais a sub-tropicais, pobremente drenadas, de relevo baixo, marcado pela inundação durante as estações úmidas e subseqüente concentração de soluções no solo durante as estações secas.

A caolinita representa um estágio subseqüente na alteração das ilitas. Desenvolve-se em solos tropicais, em superficies bem drenadas de diversos tipos de rochas, recebendo altas precipitações, em regiões onde a profundidade do solo é superior a $10 \mathrm{~m}$ e a temperatura média da ordem de $20^{\circ}$ a $30^{\circ} \mathrm{C}$ (Gaucher, apud Robert \& Kennett, 1994). Uma vez formada, a caolinita se mantém estável por longo tempo, alterando-se para gibbsita se as condições morfoclimáticas, com 
presença de clima úmido e relevo plano, forem favoráveis. Se o clima permanecer mais seco, a caolinita permanece estável.

A gibbsita forma-se pela intensificaçăo dos processos de intemperismo químico, sendo resultante da alteração da caolinita que perde a sílica. Para sua formação é necessário, além de alta umidade, que ocorram condições de intensa lixiviação para solubilizar e remobilizar os elementos (Suguio, 1980). Este fato aponta para uma gênese exterior ao ambiente lacustre.

Em lagos pode ocorrer ainda uma ressilicificação que geraria novamente caolinita, se as condições forem básicas. No caso da Lagoa Bonita, a presença de matéria orgânica no sedimento indica condições ácidas e redutoras, o que aponta para uma origem deste mineral, quando presente, externa à lagoa.

De modo geral, em lagos de passagem, onde a deposição dos constituintes minerais é essencialmente detrítica, os argilominerais presentes nos sedimentos lacustres são herdados das capas de alteração e dos solos que revestem as áreas circundantes expostas.

Desta forma, se não ocorrerem mudanças na fonte e o conjunto de argilominerais não for erodido, modificaçōes no tipo de argilomineral presente e/ou na proporção entre os constituintes, indicam modificaçōes nas condições ambientais (Krauskopf, 1979). Este pressuposto se aplica à região onde se situa a Lagoa Bonita, que constitui uma área tectonicamente estável, com relevo aplanado, onde a remoção mecânica dos minerais não é acentuada.

$A$ análise por difração de raios $X$, utilizada quando a maior parte dos constituintes ocorre nas fraçōes silte e argila, permitiu a identificação dos minerais presentes no sedimento da Lagoa Bonita, com registro do quartzo, gibbsita, os argilominerais representados pela caolinita, ilita e esmectita, além de diásporo, anatásio e rutilo.

Os dados obtidos da interpretação dos difratogramas, expressos na forma da presença e abundância relativa dos minerais de maior expressão, foram sintetizados e encontram-se representados na figura 4.1. O quartzo, a caolinita, a gibbsita e a ilita, os principais minerais presentes no perfil, são representados de forma a indicar a proporção relativa entre eles, mostrando variaçōes significativas nos pontos amostrados. Outros minerais como diásporo, anatásio, rutilo e 
esmectita, de ocorrência esporádica e restrita são indicados em função da presença ou não, sem considerar as proporçōes em que ocorrem.

A análise do conteúdo e das proporções entre o quartzo e os argilominerais presentes, possibilitou a separação de quatro seqüências, descritas da base rumo ao topo.

A primeira seqüência corresponde a uma fase anterior à instalação da lagoa, na profundidade de $283 \mathrm{~cm}$ e compreende os pontos amostrados a 295, 320 e $345 \mathrm{~cm}$ de profundidade. $O$ sedimento que ocorre a $345 \mathrm{~cm}$ é marcado pela predominância de caolinita em relação ao perfil total. Segundo Guimarães (1997), como a ilíta constitui o sedimento não-alterado do Paranoá e a caolinita a alteração do mesmo, esta caolinita pode corresponder à alteração dos metassedimentos do Grupo Paranoá in situ.

O sedimento posicionado a $320 \mathrm{~cm}$ apresenta os valores máximos de quartzo ao longo do perfil. A presença do quartzo na dimensão silte, pode ser interpretada como material proveniente do entorno, presente na unidade psamopelito-carbonatada, transportado por escoamento superficial, indicando maior energia no sistema, com chuvas suficientes para carrear o material de maior dimensão, porém sem intemperizar a caolinita já formada. A presença de quartzo na fração silte, em quantidade maior que caolinita mais ilita, em locais de deposição, indica também movimentos na massa de água.

A $295 \mathrm{~cm}$ de profundidade, o sedimento é marcado por proporçōes equivalentes entre quartzo e caolinita, sendo interpretado como a presença de água no local da deposição, indicando o início de uma fase mais úmida. A diminuição no influxo de quartzo é explicado pelo inicio da instalação da vegetação, atuando como elemento protetor do solo, dificultando o escoamento do quartzo. A presença de diásporo, um óxido de alumínio indica presença de condições oxidantes. Em toda os pontos desta seqüência, a ilita, material original dos metassedimentos do grupo Paranoá, ocorre como elemento-traço.

A segunda seqüência compreende os pontos situados a 282 e $240 \mathrm{~cm}$ de profundidade, posicionados estratigraficamente após a instalação da lagoa evidenciada pelo registro palinológico na profundidade de $283 \mathrm{~cm}$, com idade extrapolada de 26.140 anos AP. 


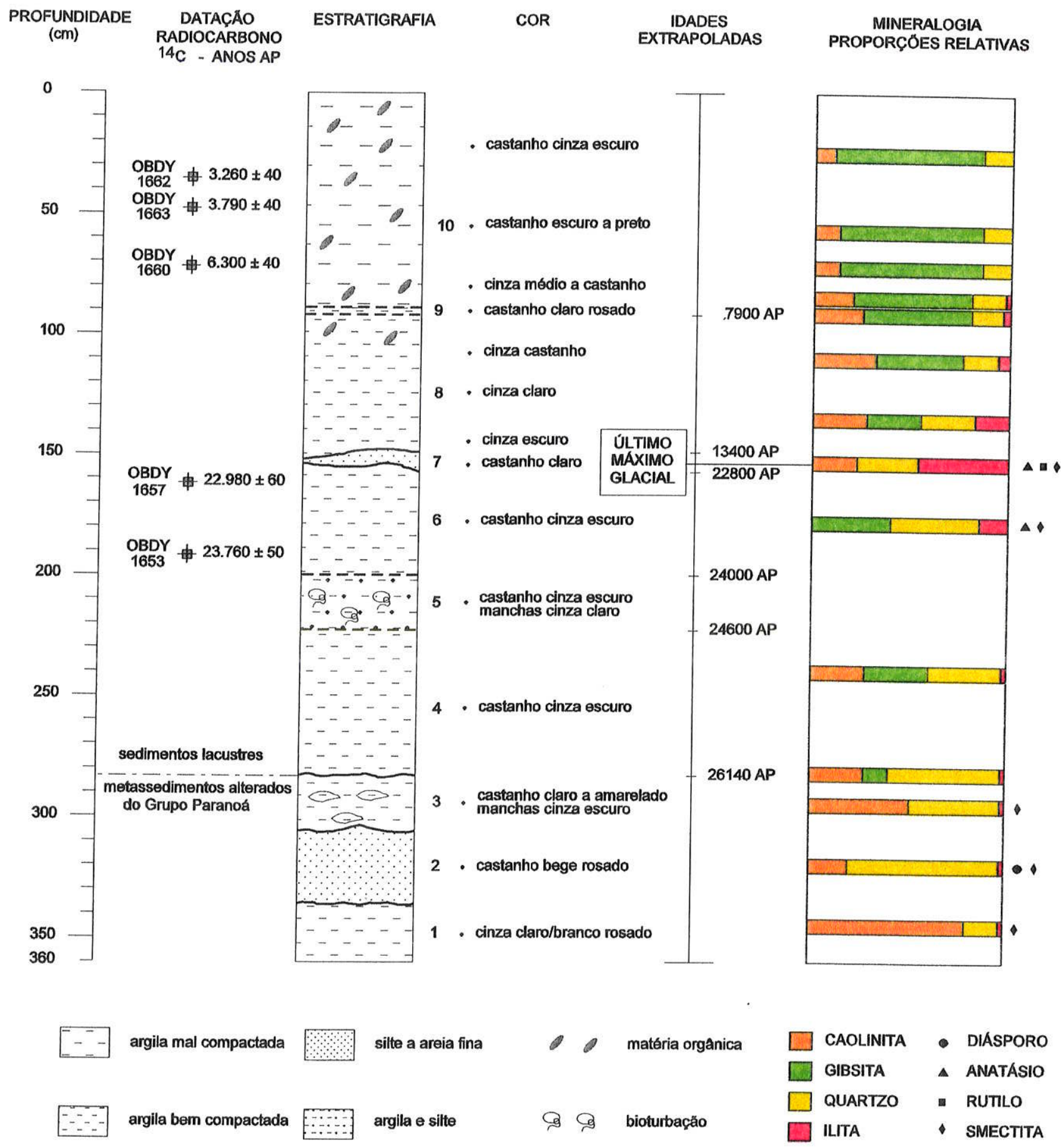

FIGURA 4.1: Estratigrafia, dataçäo radiocarbônica, datas extrapoladas e conteúdo mineralógico em proporçöes relativas de quartzo e argilominerais do testemunho da Lagoa Bonita 
A profundidade de $282 \mathrm{~cm}$ é marcada pela primeira ocorrência de gibbsita, que corresponde ao produto de alteração da caolinita, na área externa à lagoa, sob condiçōes de maior lixiviação. Na profundidade de 240 ocorre aumento da gibbsita e diminuição do quartzo, indicando condições cada vez mais úmidas da base rumo ao topo da seqüência, provocando expansão da cobertura vegetal e conseqüente estabilização do solo, dificultando o transporte superficial de material detrítico e de quartzo, principalmente das fraçōes maiores. Nesta fase, a ilita continua presente como elemento-traço. Para o topo desta seqüência obtém-se a idade extrapolada de $\mathbf{2 5 . 0 0 0}$ anos AP, correspondente ao Pleniglacial Superior.

A terceira seqüência compreende o intervalo que se inicia na profundidade de $240 \mathrm{~cm}$ inclui os pontos amostrados a 178 e $153 \mathrm{~cm}$ de profundidade. A partir de $240 \mathrm{~cm}$, rumo ao topo da seqüência há aumento gradativo de quartzo marcado a $178 \mathrm{~cm}$, onde ocorre associado à gibbsita, e um aumento significativo da ilita, cujo teor maior é atingido na profundidade de 153, onde são registrados também as maiores freqüências de anatásio, rutilo e esmectita. Estes dados sugerem uma diminuiçāo gradativa das condições úmidas, com retração da vegetação, que favorece o transporte de material detrítico, com maior exposição do solo e a instalação de processos erosivos sob condições mais secas.

A mudança drástica no conteúdo mineralógico representada pela dominância da ilita, que nas seqüências inferiores ocorria como elemento-traço, indica a exposição dos metassedimentos do Grupo Paranoá, a partir do qual a ilita foi carreada sem sofrer intemperismo químico. A gibbsita, formada na fase anterior mais úmida, é carreada nesta fase, juntamente com o quartzo, cujo influxo tende a aumentar inicialmente, com a progressiva erosāo da capa de alteração, até ocorrer a exposição da rocha-mãe, constituída predominantemente de ilita., O processo inicial de alteração da ilita que gera a esmectita, sob condições mal drenadas e clima em geral seco, é também sugerido para esta fase pela presença da esmectita.

É importante ressaltar que o pico mais intenso da ilita corresponde à camada 7, que é separada das seqüências superiores e inferiores por contatos discordantes e erosivos.

A seqüência seguinte compreende os niveis posicionados a $135 \mathrm{~cm}$, $110 \mathrm{~cm}, 90 \mathrm{~cm}$ e $85 \mathrm{~cm}$ de profundidade. É marcada por uma diminuição gradativa 
da lita e do quartzo, da base rumo ao topo da seqüência, e um aumento da gibbsita e da caolinita, indicando o retorno das condições úmidas. A profundidade de $90 \mathrm{~cm}$, que corresponde a um marco na sedimentação representado pela camada 9, onde se observa uma modificação acentuada na cor do sedimento, que se apresenta castanho rosado, não mostra uma alteração significativa no conteúdo mineralógico.

Segundo Gomes (1988), teor da ordem de 0,01\% de óxidos de ferro é capaz de colorir o sedimento, embora não seja detectada através da difração de raios $X$. A oxidação do sedimento com a conseqüente destruição da matéria orgânica e modificação na cor do sedimento, também pode ter ocorrido no sedimento da Lagoa Bonita sem formação de óxidos de ferro. No difratograma do nivel $90 \mathrm{~cm}$, não há registro de hidróxidos de ferro, uma vez que a matriz lixiviada anteriormente em uma fase que resultou na gibbsita, não apresenta mais ferro no sistema.

Estes dados reforçam a hipótese da ocorrência de uma fase, situada em torno de 7.900 anos AP, marcada por uma alteração nas condições paleoclimáticas, com a instalação de clima bissazonal de estações secas mais prolongadas, provocando um rebaixamento acentuado do nivel do lago. A exposição do sedimento possibilitou a oxidação e decomposição da matéria orgânica, com a conseqüente modificação na cor, sem contudo alterar o influxo de material detrítico.

A seqüência superior compreende os pontos amostrados em $25 \mathrm{~cm}, 57 \mathrm{~cm}$ e $72 \mathrm{~cm}$ de profundidade, representando a sedimentação holocênica a partir de $6.300 \pm 40 \mathrm{AP}$, até o presente. Apresenta-se bastante homogênea quanto ao conteúdo mineralógico, caracterizado pela presença de minerais mal cristalizados, diminuição acentuada de minerais detríticos, com ausência de ilita, presença de gibbsita e relativamente pequena de caolinita e quartzo, indicando condições de umidade nas regiōes circundantes da lagoa, responsável pela alteração da caolinita para gibbsita. 


\subsection{Análise Palinológica}

As modificações no conjunto de palinomorfos, expressas pelas variações qualitativas e quantitativas dos diferentes tipos identificados, sugerem mudanças paleoclimáticas, permitindo a reconstrução da paisagem durante o Pleistoceno tardio-Holoceno.

Os resultados da análise palinológica são expressos na forma de diagramas de porcentagem e de concentração, elaborados pelo Programa Tilia e Tilia Graph, usando-se a soma total do pólen, excluindo-se os esporos de Pteridófitas, algas e os outros palinomorfos presentes na amostra. O valor da soma de pólen de cada nível é indicado na extremidade direita de todos os diagramas de porcentagem. As datações radiocarbônicas e a litologia do testemunho estão indicadas na extremidade esquerda de todos os diagramas $e$ as camadas foram descritas no item 4.1 (Descrição do testemunho de sondagem).

Os diagramas podem ser organizados por tipos de vegetação, por tipos de hábitos, ou indicar o comportamento de cada tipo polínico ao longo da seqüência, em valores absolutos de grãos por centímetro cúbico de sedimento (grãos $/ \mathrm{cm}^{3}$ ), ou pela porcentagem em relação à soma de pólen. Alguns perfis palinológicos representam a soma de dois ou mais tipos com características comuns, conforme o item 3.2.2.4 (Organização dos dados).

Os diagramas de porcentagem ressaltam as mudanças relativas dos tipos de vegetação ao longo do tempo, mas não informam quanto à abundância independente de cada tipo, apresentando também distorções na curva, principalmente quando a concentração de pólen cai acentuadamente, ou quando algum tipo é superabundante. Os diagramas de concentração, indicam a presença e a abundância de cada tipo polínico em valores absolutos, independente dos valores dos outros componentes.

Os diagramas de porcentagem compreendem as seguintes figuras: 4.2 onde estão indicadas as curvas de pólen de todos os táxons, 4.3 mostra as curvas dos elementos botânicos reunidos por tipos de hábitos, 4.4 mostra os táxons reunidos por fitofisionomias, 4.5 os táxons reunidos por tipos de vegetação e 4.6 mostra as curvas expandidas de todos os táxons. Algumas famílias como 
Gramineae, Compositae e Cyperaceae foram separadas em curvas individuais, mesmo nos diagramas de representaçōes por tipos de vegetações ou tipos de hábitos, para evitar as distorções e facilitar as interpretações. Em alguns casos, Pteridófitas e Algas estão também indicadas e os seus valores em porcentagem foram calculados com relação à soma de grãos de pólen.

Os diagramas de concentração compreendem as seguintes figuras: 4.7 onde está representada a concentraçäo diferentes tipos de palinomorfos; 4.8 e 4.9 mostram as curvas do pólen dos elementos arbóreos de mata e vereda; 4.10 mostra as curvas de pólen dos elementos arbóreos do cerrado e dos que ocorrem em mais de um tipo de vegetação; 4.11 e 4.12 mostram as curvas dos elementos herbáceos do cerrado e de outros elementos; 4.13 indica as curvas dos elementos palustres, de Pteridófitas e algas e 4.14 onde os elementos botânicos foram reunidos por tipos de vegetação.

Os dados relativos à concentração de partículas de carvão ao longo da seqüência e da superfície estão representados no histograma 4.15 e a caracterização palinológica do conjunto atual da vegetação, a partir das amostras superficiais da Lagoa Bonita e da Vereda de Águas Emendadas, está representada nos histogramas $4.16,4.17,4.18,4.19$ e 4.20 .

Todos os diagramas e histogramas encontram-se no final deste item.

Os três níveis inferiores da seqüência (LBB-30, 31 e 32), posicionados abaixo da profundidade de $283 \mathrm{~cm}$, apresentaram-se estéreis em palinomorfos. $O$ registro de palinomorfos inicia-se no nivel LBB-29, posicionado a $281 \mathrm{~cm}$ de profundidade, quando se inicia a sedimentação lacustre, a partir de onde foram identificadas sete ecozonas, representadas em todos os diagramas e descritas a seguir, da base para o topo da seqüência.

\section{ECOZONA LB 1: 26.040 - ca. 25.390 anos AP}

\section{0 a $255 \mathrm{~cm}$ de profundidade}

Esta ecozona, cuja base corresponde também ao momento de implantação da lagoa, caracteriza-se pelo predomínio palinomorfos de elementos arbóreos de mata e palustres (Figuras 4.4 e 4.14), onde tipos como Neea, Antonia ovata, Cupania, Ilex, Symplocos e Trema apresentam valores de concentração superiores a 1.000 grãos $/ \mathrm{cm}^{3}$ de sedimento, seguidos de Hedyosmum e Rapanea, 
elementos considerados comuns, juntamente com llex, em espectros polínicos de fases glaciais (Colinvaux et al., 1996; De Oliveira, 1992; 1996), além da presença de Podocarpus, em concentrações ainda baixas (Figuras 4.7, 4.84 .9 e 4.13).

Corresponde também a concentrações altas de outros elementos arbóreos, como Melastomataceae e Myrtaceae e baixas de Palmae (exceto Mauritia) e de elementos arbóreos de cerrado (Figura 4.10)

Entre os elementos herbáceos e outros elementos, destaca-se a ocorrência de Acalypha, Amaranthaceae, Caryophillaceae, Eriocaulaceae, Gramineae e Compositae que, embora ocorram em valores superiores a $500 \mathrm{grãos} / \mathrm{cm}^{3}$ (Figuras 4.11 e 4.12), não são muito expressivos ao longo do perfil.

Quanto aos elementos de ambiente palustre, com exceção de Mauritia, ausente nesta zona, todos encontram-se bem representados, principalmente Cyperaceae, que atinge os valores máximos, e as plantas aquáticas representadas por Myriophyllum, Alismataceae e Pontederiaceae/Xyridaceae (Figura 4.13). Embora as concentrações dos elementos palustres sejam inferiores às dos herbáceos, os diagramas de porcentagem por tipos de hábitos, tipos de vegetação e por fitofisionomias (Figuras 4.3, 4.4 e 4.5), permitem visualizar o predomínio dos elementos arbóreos e palustres sobre os herbáceos.

Nesta ecozona, a presença de Pteridófitas é marcada principalmente pelas ocorrências de Lycopodium cernnum e Cyathea, um gênero de samambaia arborescente, que atinge seus valores máximos ao longo da curva e que constitui um elemento típico de mata úmida. Entre as Pteridófitas é marcante também a ausência de Isoëtes e quanto às algas, vários tipos são encontrados, porém em valores baixos (Figura 4.13).

No diagrama de concentração dos diferentes tipos de palinomorfos, reunidos por grupos taxonômicos, observam-se altos valores da soma total de pólen e baixos de Pteridófitas e Fungos (Figura 4.7).

Nesta ecozona, a grande freqüência de elementos de mata, principalmente as altas concentrações de elementos arbóreos, com táxons que podem caracterizar condições mais frias, como llex, Rapanea e Hedyosmum, aliada às porcentagens expressivas de elementos aquáticos, embora as algas plantônicas presentes ocorram em baixas concentraçōes, indicam que a instalação da lagoa se deu em condições de alta umidade. Além disso, o clima seria mais frio que o 
atual, com vegetação predominantemente arbórea, sugerindo a presença de uma mata no entorno da lagoa.

\section{ECOZONA LB 2: 25.390 - ca. 24.350 anos AP}

\section{5 a $215 \mathrm{~cm}$ de profundidade}

Caracteriza-se por declínio relativo de elementos arbóreos de mata em relação à ecozona anterior, porém com valores ainda expressivos de táxons como Ilex, Cupania, Symplocos, Trema, Myrtaceae e Melastomataceae/Combretaceae, além do primeiro registro de Curatella, outras Leguminosae e Cunnoniaceae (Figuras 4.8, 4.9 e 4.10).

A queda na concentração dos elementos arbóreos é acompanhada por pequeno aumento de elementos herbáceos como Caryophyllaceae, Cuphea, Ericaceae, Eriocaulaceae, Gramineae, Polygalaceae, Rubiaceae e Euphorbiaceae outras (Figuras 4.11 e 4.12). O registro de Amaranthaceae, cujo pico ocorre nesta zona, é representado pela presença marcante de Alternanthera (Tabela 3.3).

Em relação aos elementos palustres, há uma queda na concentração de Cyperaceae da base para o topo deste intervalo e ocorrência em valores constantes e pouco mais elevados de elementos aquáticos, como Alismathaceae, Myriophyllum e Pontederiaceae/Xyridaceae, em relação ao intervalo anterior (Figura 4.13).

Quanto às Pteridófitas, que ainda continuam mal representadas (Figura 4.4), observa-se uma queda na concentração de Cyathea e a ausência de Isoëtes. As algas plantônicas registram aumento acentuado de Mougeotia, da base para o topo do intervalo (Figura 4.13).

Os diagramas de porcentagem por tipos de vegetação, tipos de hábitos e fitofisionomias (Figuras 4.3, 4.4 e 4.5) permitem visualizar uma pequena retração de palinomorfos de plantas de brejo e de árvores, embora a soma dos dois ainda represente cerca de $60 \%$ do conjunto polínico (assemblage), ocorrendo aumento relativo dos elementos herbáceos, aliado ao aumento das algas plantônicas.

Embora o registro indique modificações nas proporções de ocorrência, o conjunto dos elementos botânicos permanece praticamente inalterado em relação ao anterior, exceção feita ao primeiro registro, com baixas concentrações de Curatella e Cunnoniaceae. 
O conjunto da ecozona LB 2 sugere pequena oscilaçãa nas condições vigentes na ecozona anterior, com diminuição relativa da umidade que conduz ao aumento dos elementos herbáceos e declínio dos arbóreos, e uma tendência à diminuição da temperatura, sugerida pelos aumentos acentuado de Mougeotia e relativo de Rapanea, da base para o topo do intervalo. Nesta fase a vegetação no entorno da Lagoa Bonita, ainda é representada por uma mata úmida.

\section{ECOZONA LB 3: 24.350 - ca. 19.730 anos AP}

\section{5 a $145 \mathrm{~cm}$ de profundidade}

Esta ecozona exibe as maiores concentrações de palinomorfos, superiores a 400.000 grãos de pólen por $\mathrm{cm}^{3}$ de sedimento (Figura 4.7).

Caracteriza-se pelo registro dos maiores valores de concentração de Copaifera, Hedyosmum, Ilex, Rapanea, Myrtaceae, Solanaceae e Podocarpus, este último com ocorrência predominante neste intervalo (Figuras 4.8, 4.9 e 4.10). Outros elementos arbóreos, tanto de mata quanto de cerrado, já registrados no intervalo anterior, também apresentam aumento significativo com relação ao intervalo anterior, com valores máximos em torno de $165 \mathrm{~cm}$ de profundidade que corresponde à idade de $22.980 \pm 60$ anos $A P$.

Os elementos herbáceos também mostram aumento de concentração em relação ao intervalo anterior, com Compositae, Ericaceae, Eriocaulaceae, outras Euphorbiaceae, Gramineae, Labiatae, Polygalaceae, Rubiaceae, e Smilax, atingindo os valores máximos ao longo da seqüência (Figuras 4.11 e 4.12). Cuphea, que também atinge o pico ao longo da curva nesta ecozona, apresenta uma distribuição concentrada nesta fase (Figura 4.11)

Nas curvas dos elementos palustres, a Mauritia ainda está ausente, mas em relação ao intervalo anterior, ocorre aumento de Cyperaceae e os maiores valores de Pontederiaceae/Xyridaceae, sugerindo o aumento da umidade (Figura 4.13).

Em relação às Pteridófitas, esta ecozona é marcada pela ausência de Cyathea, pelo aparecimento de Isoëtes e pela expansão de Lycopodium cernnum que atinge os valores máximos ao longo da seqüência (Figura 4.13). Quanto às algas, Spirogyra continua ocorrendo em valores constantes e baixos, há relativo aumento de Botryococcus e Chlamydomonas e acentuado aumento de Mougeotia 
e Zygnemataceae, com valores que permanecem máximos em toda a ecozona, indicando queda acentuada na temperatura (De Oliveira, 1992; 1996).

Em geral, esta ecozona caracteriza-se por aumento gradativo de praticamente todos os elementos botânicos presentes no intervalo inferior, até atingir um máximo por volta de 22.900 anos AP, quando se inicia uma tendência ao declínio de todos os tipos, atingindo concentrações muito baixas de todos os palinomorfos no topo da ecozona (Figura 4.7).

Estes dados sugerem aumento gradativo de umidade e queda acentuada de temperatura, até cerca de 22.900 anos AP (Pleniglacial superior), seguido por condições cada vez mais frias e secas até a instalação de climas semi-áridos, responsáveis pelo contato erosivo no topo desta ecozona, há cerca de 19.700 anos AP. A partir desta época, o declínio da vegetação, com a conseqüente exposição e erosão do solo, ensejou a deposição da camada 7 que é essencialmente detrítica.

Embora as variações das concentrações de palinomorfos permitam inferir aumentos na umidade e diminuição na temperatura, a associação resultante dos aumentos generalizados dos elementos arbóreos, herbáceos, palustres, aquáticos e de algas, não encontra similaridade com quaisquer das 11 fitofisionomias atuais do bioma Cerrado, descritas por Ribeiro \& Walter (1998) no Planalto Central.

Os diagramas de porcentagem por fitofisionomias, tipos de vegetação e tipos de hábitos, indicam porcentagens equivalentes de elementos herbáceos, arbóreos e palustres. Entretanto, os valores máximos de elementos arbóreos de mata ao longo da curva, registrados neste intervalo, sugerem a presença conspícua da mata úmida. A curva dos elementos herbáceos (Figura 4.3), inclui na soma as Gramineae, que podem representar tanto espécies aquáticas da familia como outras adaptadas a um ambiente com alta umidade.

\section{ECOZONA LB 4: 13.040 - ca. 8.390 anos AP}

\section{5 a $95 \mathrm{~cm}$ de profundidade}

Esta ecozona se inicia acima do contato erosivo e corresponde a uma fase caracterizada por um conjunto diferente de palinomorfos, tanto em termos qualitativos como quantitativos em relação às ecozonas inferiores. 
Caracteriza-se pelo declínio acentuado de palinomorfos de elementos palustres e arbóreos de mata, substituídos em grande parte pelos elementos arbóreos de cerrado (Figura 4.10), inicialmente em valores baixos mas com tendência a aumento rumo à porção intermediária da ecozona. Alguns elementos, como Brosimum, foram registrados pela primeira vez nesta fase e outros como Antonia ovata e Trema encontram-se bem representados. Este último gênero, além de ocorrer em todos os tipos de ambientes, é considerado um elemento colonizador, sendo uma das primeiras espécies arbóreas a surgir em áreas abandonadas (Lorenzi, 1992) (Figura 4.10).

Os elementos herbáceos estão representados em valores menores que os registrados na ecozona LB 3, anterior ao nível erosivo, e apresentam uma tendência ao decréscimo para o topo da ecozona.

Entre os elementos palustres, ainda não há registro de Mauritia, Cyperaceae apresenta concentrações constantes e Pontederiaceae/Xyridaceae apresentam declínio acentuado com relação à ecozona anterior, com valores próximos de zero no limite superior da ecozona.

Entre as Pteridófitas, é marcante 0 aumento da freqüência de Isoëtes e a queda acentuada de Lycopodium cernnum. Entre as algas Mougeotia e Zygnemataceae praticamente desaparecem e o registro de algas fica restrito basicamente à presença do gênero Botryococcus.

Quanto aos tipos de vegetação e de fitofisionomias, observa-se uma tendência ao aumento de elementos de cerrado e de mata e declínio de elementos palustres (Figuras 4.4, 4.5 e 4.14).

O topo da ecozona é marcado por uma queda acentuada na concentração de todos os tipos de palinomorfos, que sugerem para esta ecozona condições mais quentes e úmidas que o intervalo anterior, representado pela fase seca responsável pela erosão seguida de sedimentação detrítica.

\section{ECOZONA LB 5: 8390 - ca. 6300 anos AP}

\section{5 a $75 \mathrm{~cm}$ de profundidade}

O início desta ecozona é marcado pelos menores valores de concentrações de todos os tipos de palinomorfos do perfil. Corresponde ao nível LBB-10, onde se verificou o menor valor da soma de pólen (Figura 4.2), 
relacionado à camada 9. Esta camada caracteriza-se por sedimento de cor clara, indicativa de processos oxidantes, provavelmente responsáveis pela destruição parcial dos palinomorfos.

Os elementos arbóreos de mata continuam muito escassos, destacando-se as ocorrências de Antonia ovata, Copaífera e Trema. Os elementos arbóreos de cerrado, tais como Byrsonima e Stryphnodendron, tendem a se tornar mais freqüentes, além de concentrações expressivas de Anacardiaceae.

Entre os elementos herbáceos, constata-se a presença de Gramineae com concentrações aproximadamente constantes ao longo da seqüência, fato que se verifica também para a família Compositae que apresenta elementos herbáceos e arbóreos. Acalypha, outras Euphorbiaceae, Labiatae e Rubiaceae mostram tendência de acréscimo rumo à superfície.

Esta ecozona é marcada por um pico expressivo de Isoëtes, uma Pteridófita aquática, geralmente submersa, que necessita da luz solar para realizar a fotossíntese. Esta característica parece sugerir uma lâmina de água rasa, com menos de $3 \mathrm{~m}$ de profundidade. Botryococcus, que é uma alga de ambiente pantanoso, é freqüente neste intervalo, enquanto algas plantônicas como Spirogyra ocorrem em baixos teores. Zygnemataceae e Mauritia estão ausentes (Figura 4.13).

O diagrama de concentração de tipos de vegetação e o de porcentagem por conjuntos evidenciam o início de predomínio da vegetação de cerrado na região (Figuras 4.4, 4.5 e 4.14).

Os dados sugerem condições relativamente mais secas, nesta fase, em relação à ecozona anterior, que indicava o retorno de condições úmidas após a fase erosiva.

As presenças mais conspícuas de Isoëtes e de Botryococcus, mais freqüentes nesta ecozona e a ausência de Zygnemataceae, são indicativas de condições mais secas e quentes, com sazonalidade acentuada. As estações secas mais prolongadas rebaixariam o nível de água do lago até atingir condições pantanosas, com exposição sub-aérea e oxidação do sedimento e conseqüente destruição parcial dos palinomorfos. O registro polínico desta fase, posicionada a $90 \mathrm{~cm}$ de profundidade, teria uma idade extrapolada de ca. 7.900 anos AP, com as concentrações mais baixas de palinomorfos (Figura 4.7). 


\section{ECOZONA LB 6: 6.300 - ca. 3.260 anos AP}

\section{5 a $35 \mathrm{~cm}$ de profundidade}

A característica marcante desta fase é a presença pólen de Mauritia até então ausente nas curvas (Figura 4.9). Os elementos arbóreos, bem como os herbáceos de cerrado, continuam sua tendência de aumento rumo à superfície.

Entre as árvores da mata os registros de Antonia ovata, Copaifera, e Trema são conspícuos, porém com valores sempre inferiores aos encontrados na porção inferior do perfil, anterior à fase erosiva.

Os elementos herbáceos e subarbustivos continuam a tendência de aumento de freqüência rumo à superfície, exceção feita a Acalypha e Mimosa que apresentam picos, e a ausência de Eriocaulaceae.

Entre os elementos palustres somente Cyperaceae se mantém constante e Umbelliferae mostra uma tendência ao aumento pronunciado rumo à superfície. As Pteridófitas praticamente desaparecem e as algas são representadas principalmente por Botryococcus e Spirogyra, que ocorrem com concentrações máximas.

Oscilação na umidade nesta ecozona é registrada em ca. 5.300 anos AP, evidenciada com os maiores valores de partículas de carvão ao longo do perfil (Figura 4.15), que corresponde também a uma queda nos valores de alguns elementos arbóreos de mata e cerrado (Figuras $4.8 ; 4.9$ e 4.10 ). A queda nos valores de Mauritia (Figura 4.8) cujo primeiro registro ocorre nesta ecozona, e que apresenta uma tendência geral de aumento em direção ao topo da seqüência, sugere também queda na umidade ou freqüência maior de queimadas no entorno da Lagoa Bonita neste período.

A presença de Mauritia e as freqüências máximas de fungos ao longo do perfil, indicam condições gradativamente mais úmidas e mais quentes, com pequenas oscilações na umidade.

\section{ECOZONA LB 7: 3260 - ca. 440 anos AP}

\section{5 a $5 \mathrm{~cm}$ de profundidade}

A ecozona mais superficial exibe um conjunto de palinomorfos que refletem condiçōes ambientais atuais, estabelecidas na Vereda de Águas Emendadas 
(Barberi, 1998), caracterizado pela predominância de elementos de cerrado $(>75 \%)$.

As maiores concentraçōes de Brosimum e Stryphnodendron, típicos dos cerrados desta região do Planalto Central, além de freqüências expressivas de Antonia ovata e Cunnoniaceae, foram notadas. A concentração máxima de Mauritia (Figura 4.8) e de outras Palmae, ao longo de todo o testemunho nesta ecozona, é sugestiva de expansão máxima da vereda em ca. 2.100 anos AP (idade extrapolada). Embora menos freqüentes que na seqüência inferior, alguns elementos de mata como Copaífera, Cupania, Symplocos e Trema também estão presentes.

Os elementos herbáceos atingem altas frequeências neste intervalo e Acalypha atinge o máximo. Entre os elementos palustres, Cyperaceae se mantém constante e ocorre aumento acentuado de Umbelliferae, com o máximo na base desta ecozona, enquanto as Pteridófitas apresentam as mais baixas freqüências e as algas são representadas principalmente por Spirogyra e Botryococcus.

Os dados apontam para um mosaico de vegetação, com fitofisionomias características de cerrados, onde se destaca na área estudada, o predomínio do Cerrado típico, além da Vereda e da Mata nas proximidades da Lagoa, e o Campo Limpo Úmido onde o lençol freático aflora ou está próximo à superfície. 


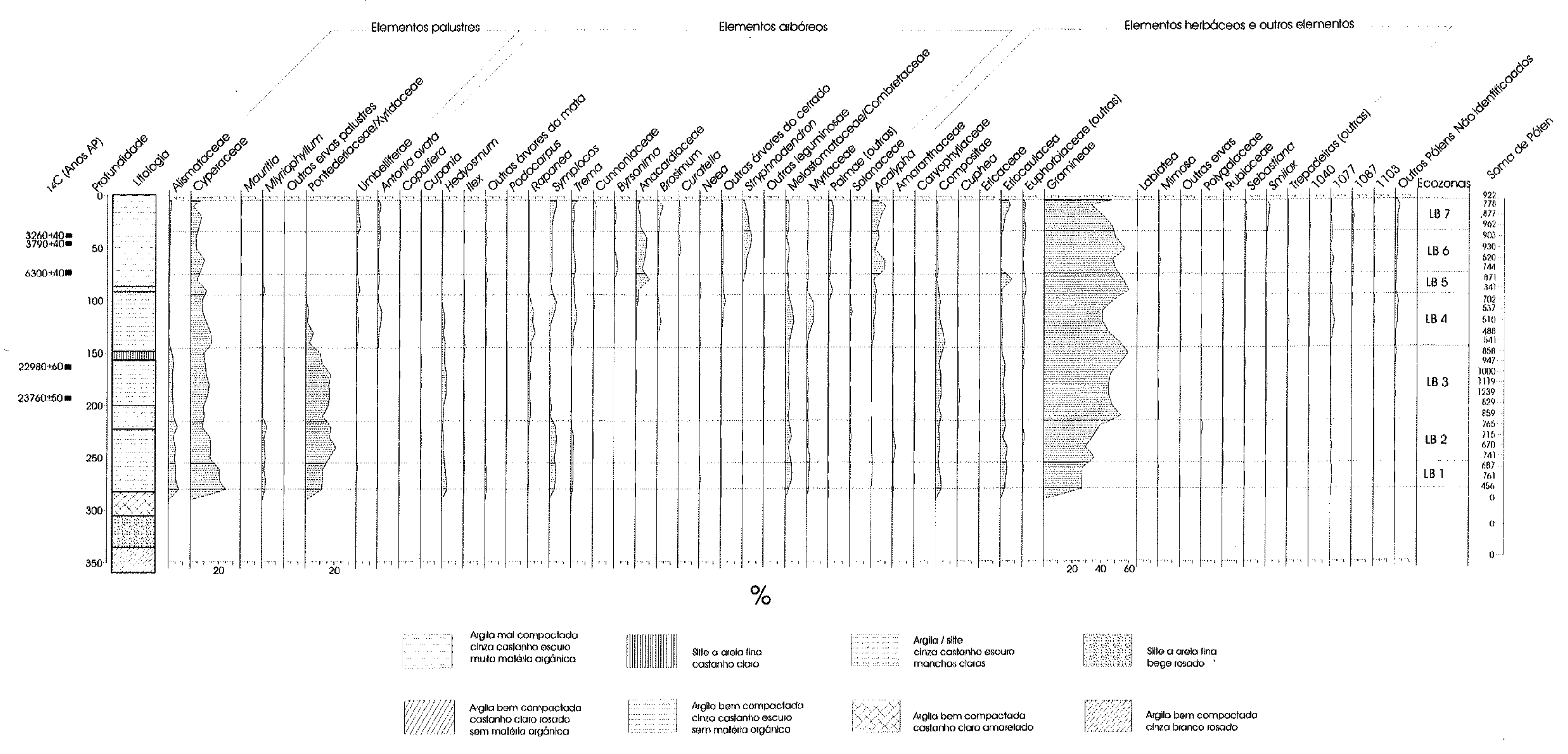

FIGURA 4.2: Diagrama de porcentagem dos tipos polínicos da Lagoa Bonita, DF 

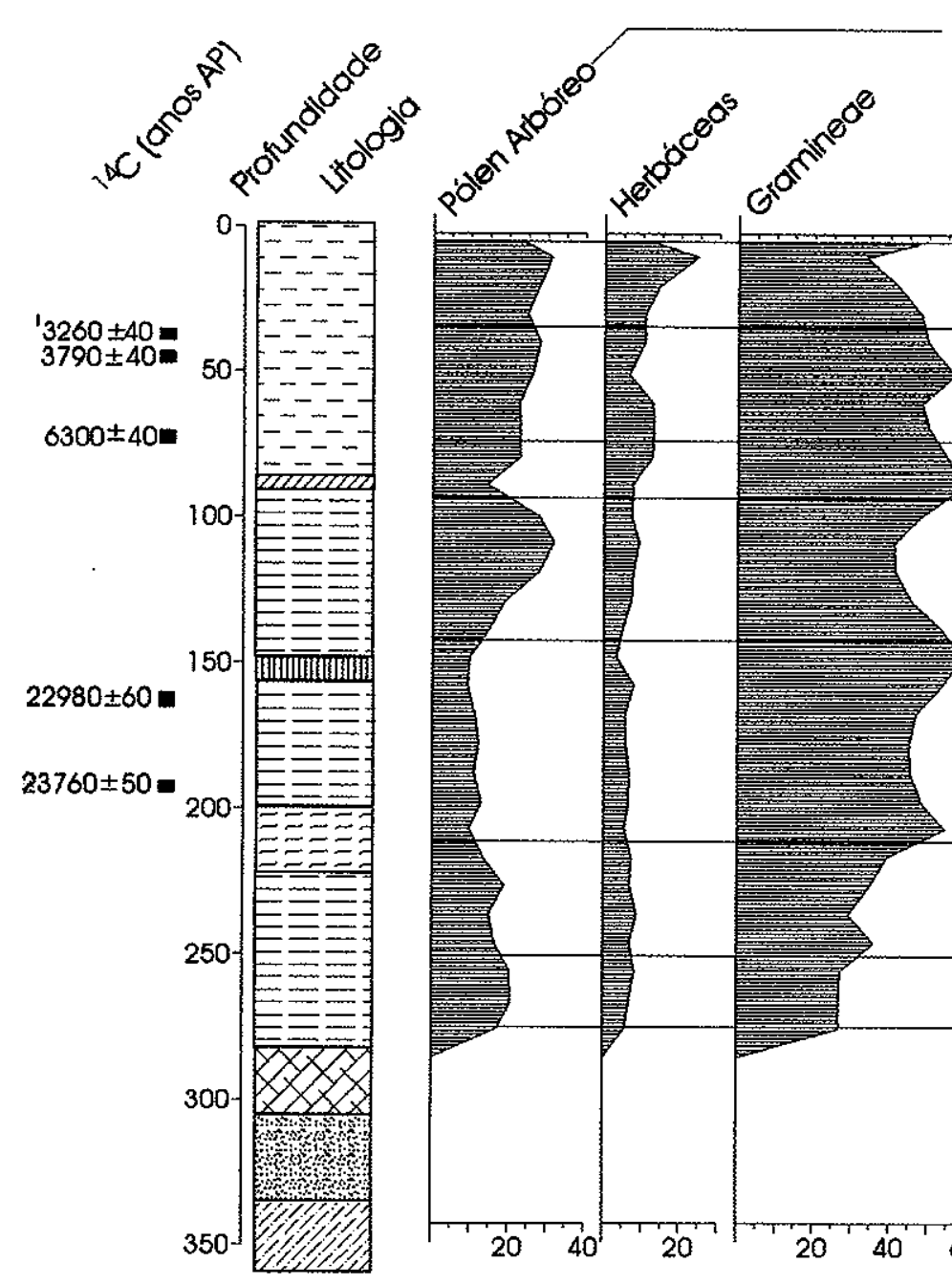

Diferentes tipos de hábitos
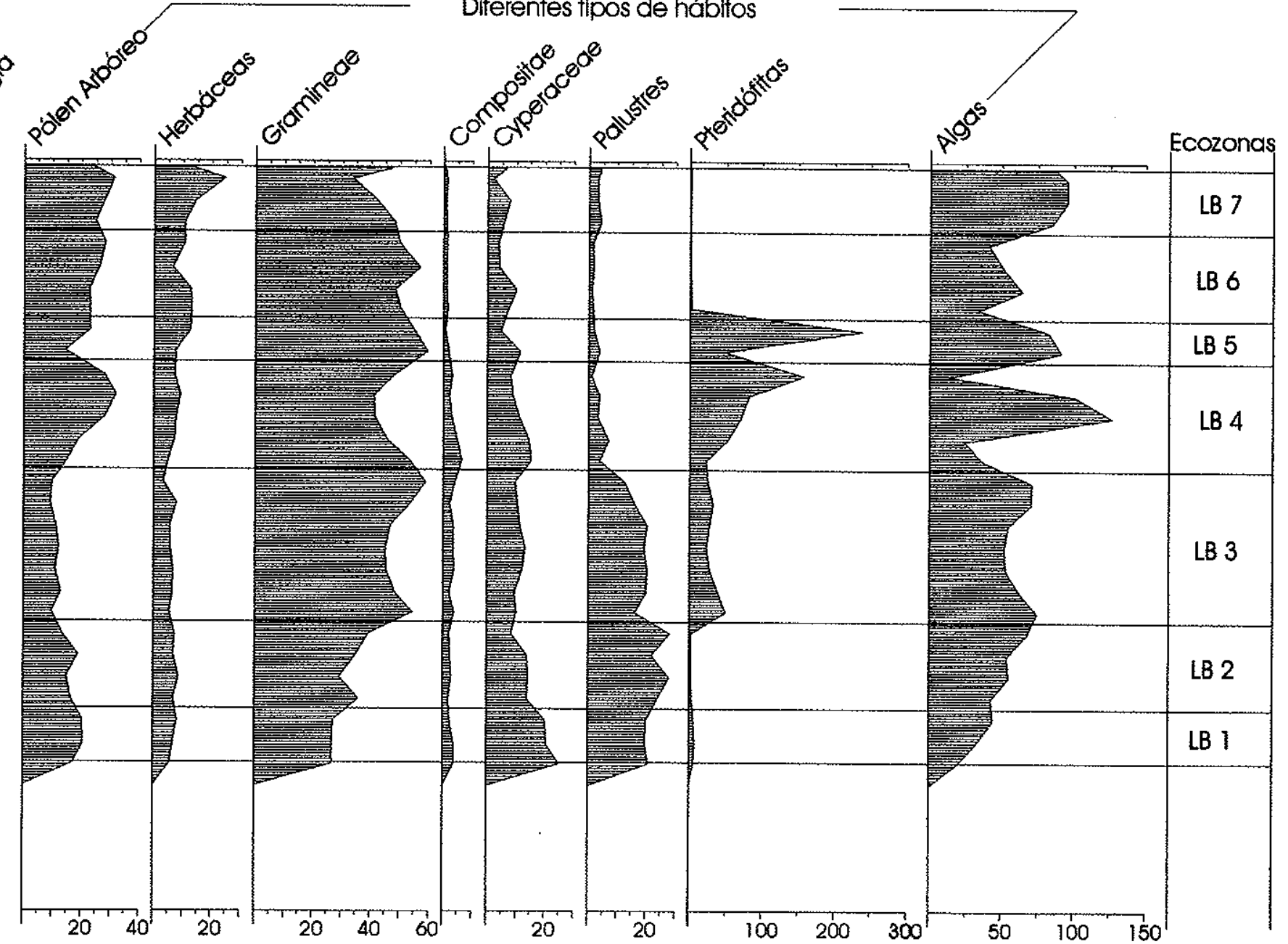

922

$877-$

$962-$

$903-1$
$930-1$
$520-$

Argla mal compaciada

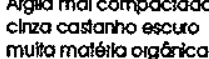

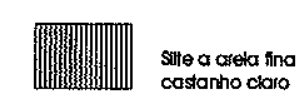

$\%$

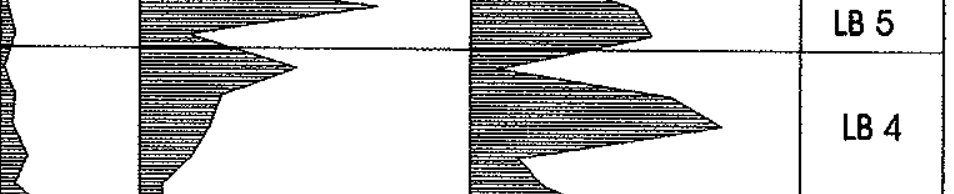




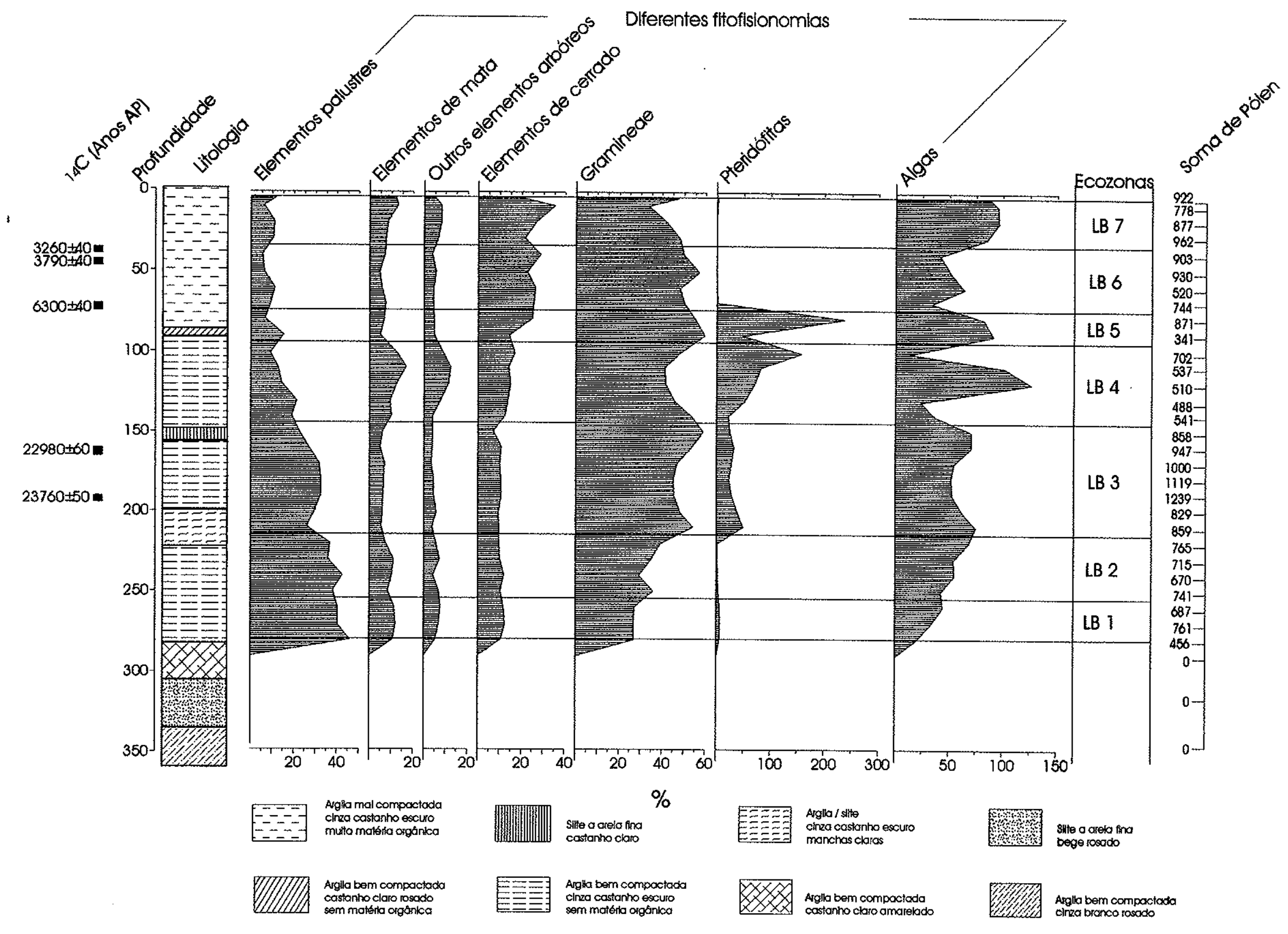

$\vec{O}$

FIGURA 4.4: Diagrama de porcentagem das diferentes fitofisionomias 

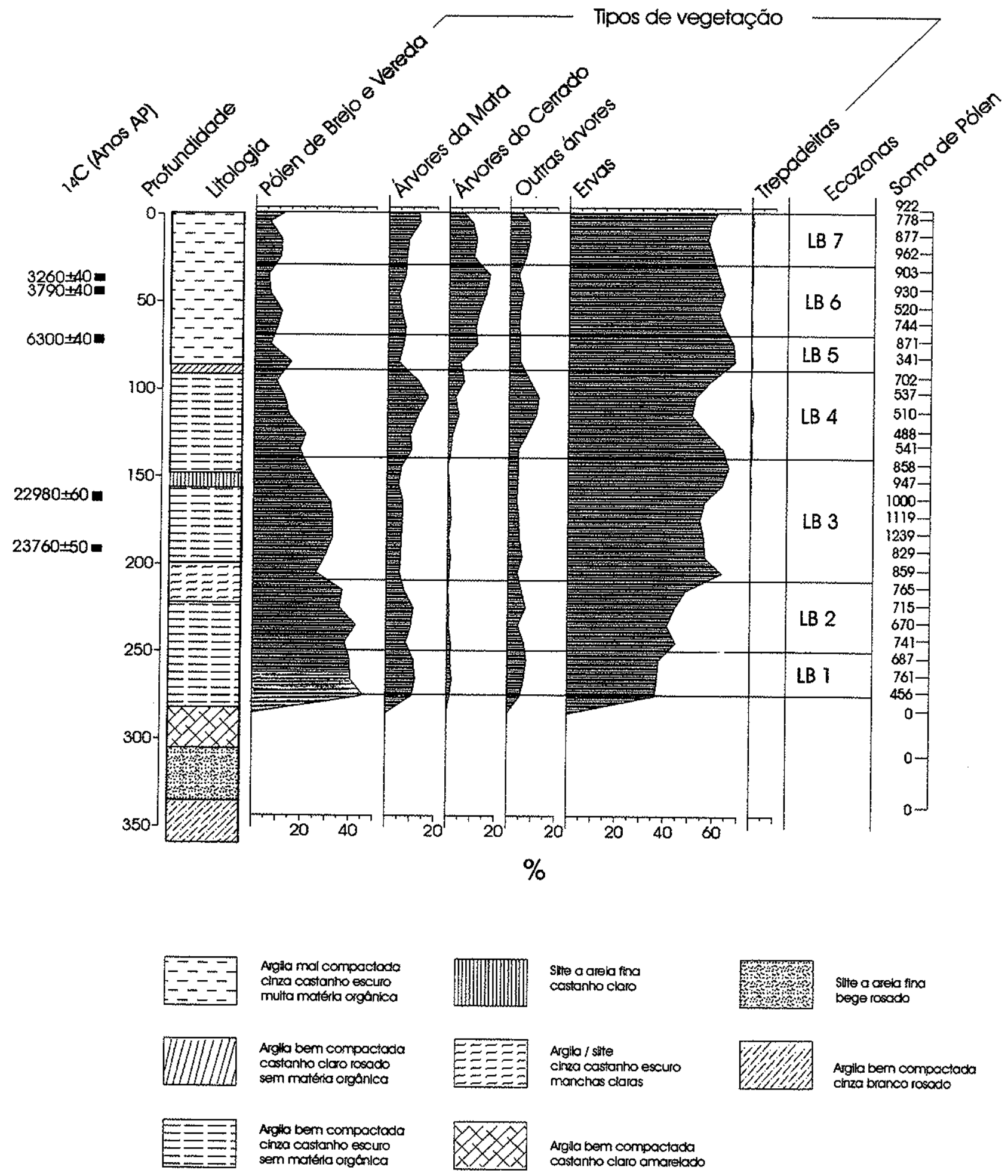

FIGURA 4.5: Diāgrama de porcentagem dos diferentes tipos de vegetação 


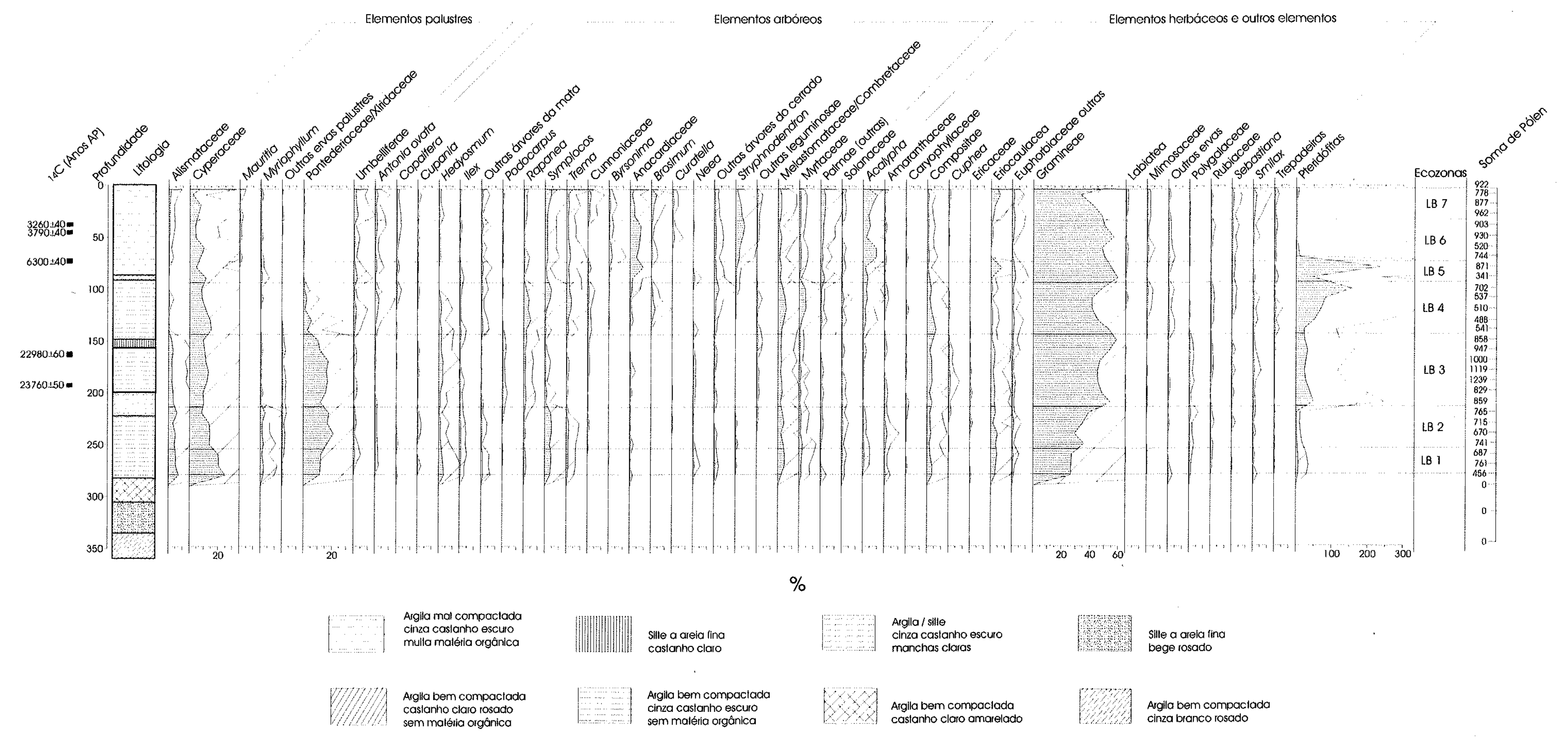

FIGURA 4.6: Diagrama de porcentagem dos palinomorfos em curvas expandidas 


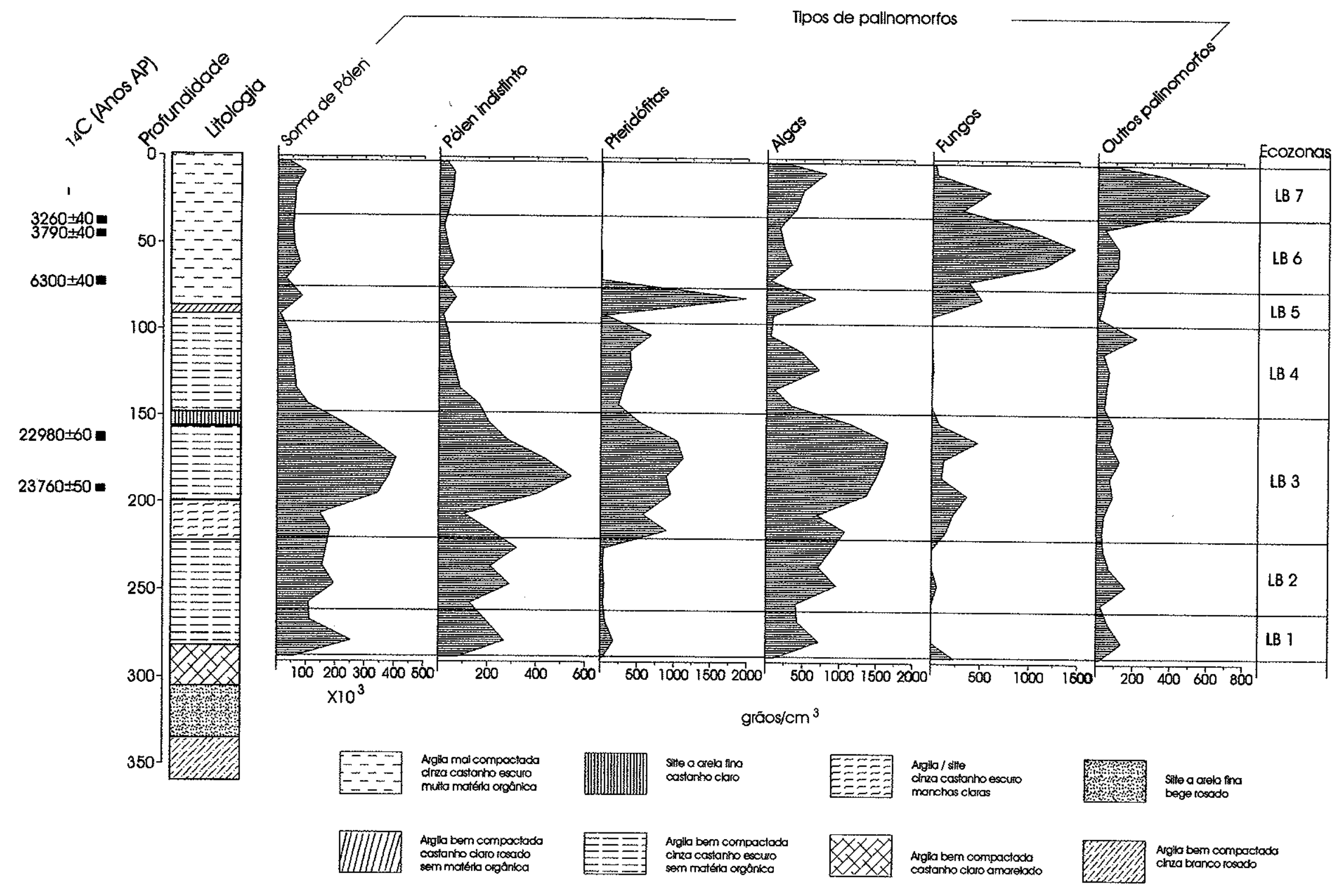

FIGURA 4.7: Diagrama de concentração dos diferentes tipos de palinomorfos 


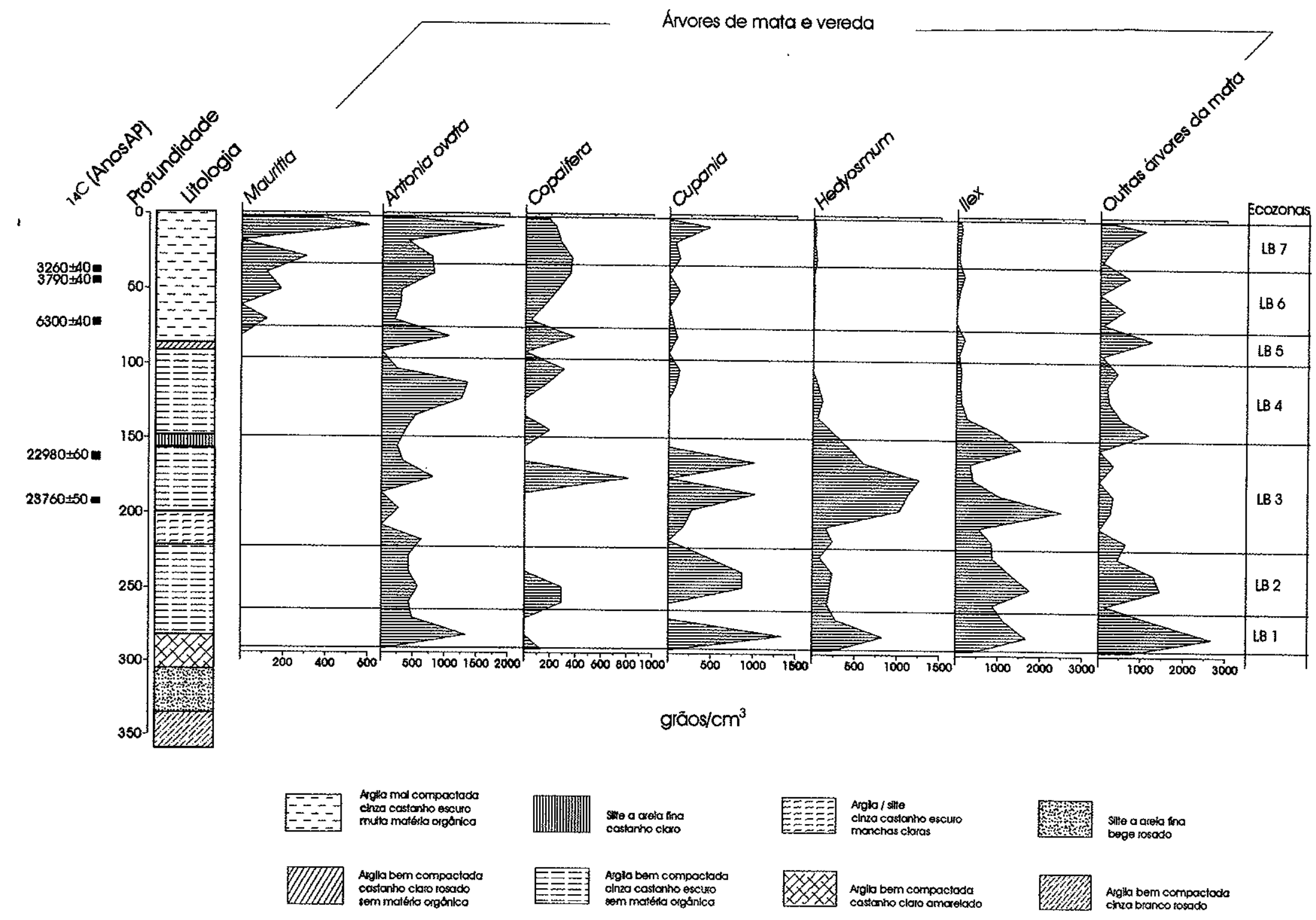

FIGURA 4.8: Diagrama de concentração dos elementos arbóreos de Vereda e Mata - I 


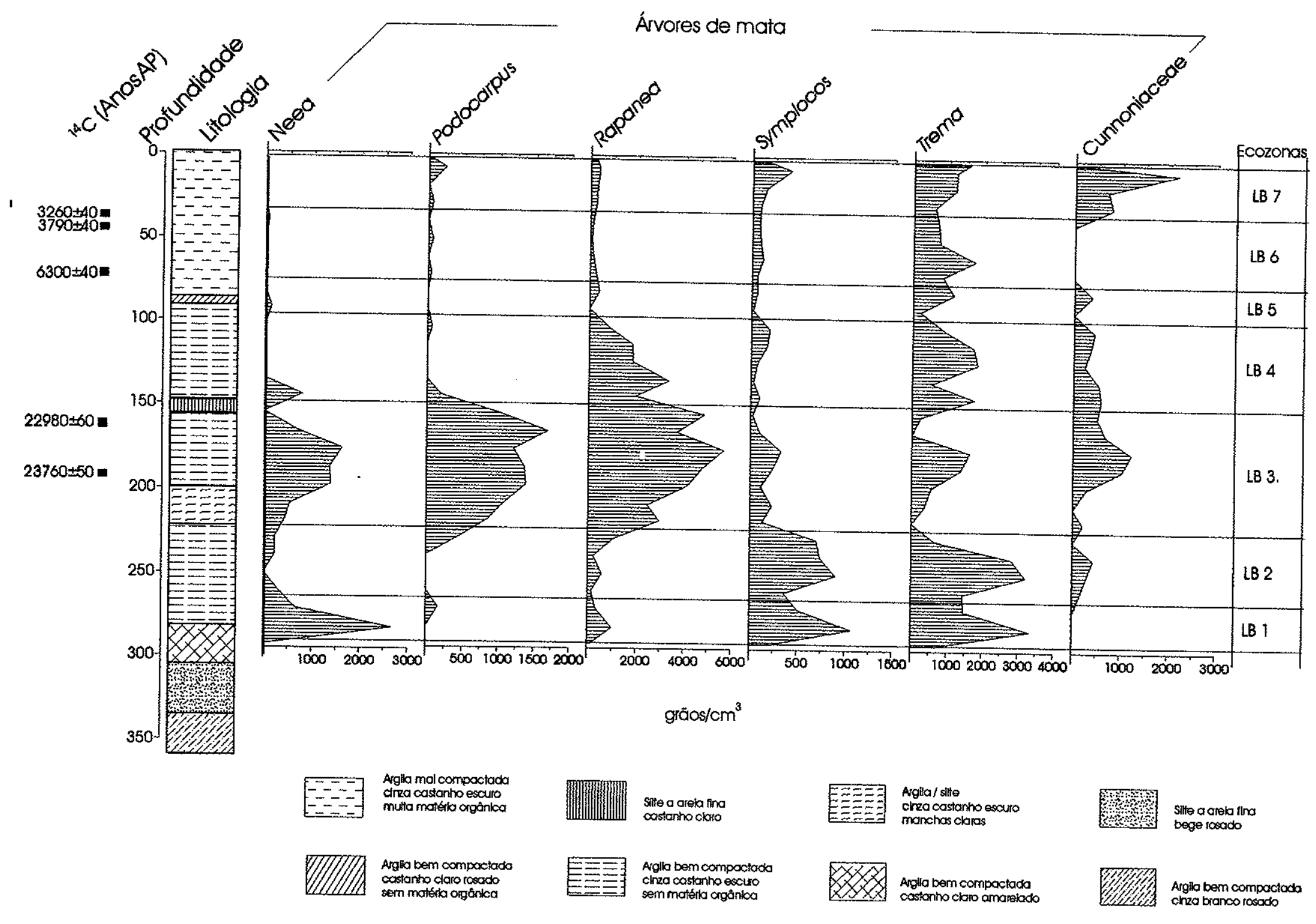

FIGURA 4.9: Diagrama de concentração dos elementos arbóreos de Mata - ॥ 


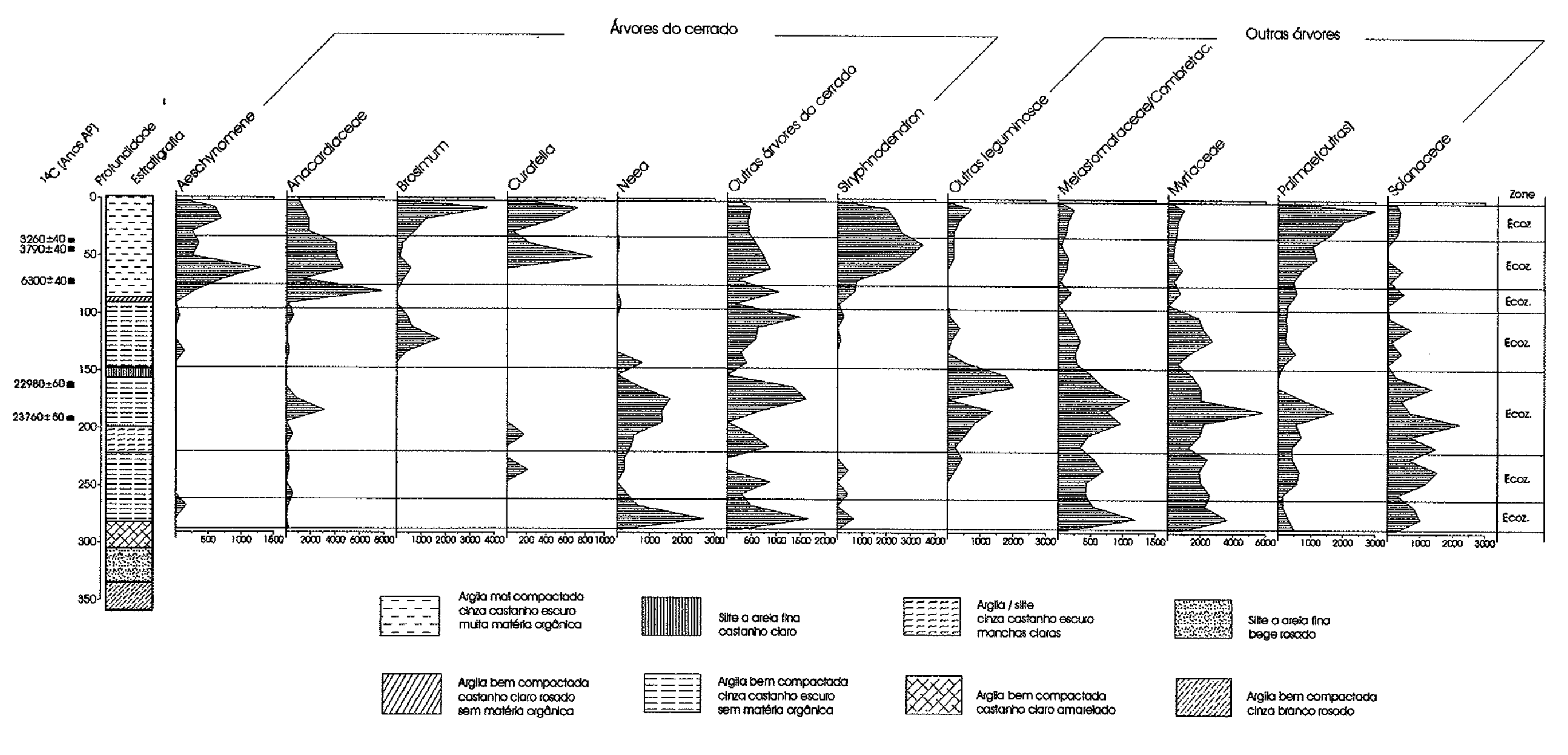

FIGURA 4.10: Diagrama de concentração dos elementos arbóreos de Cerrado e outros elementos arbóreos 


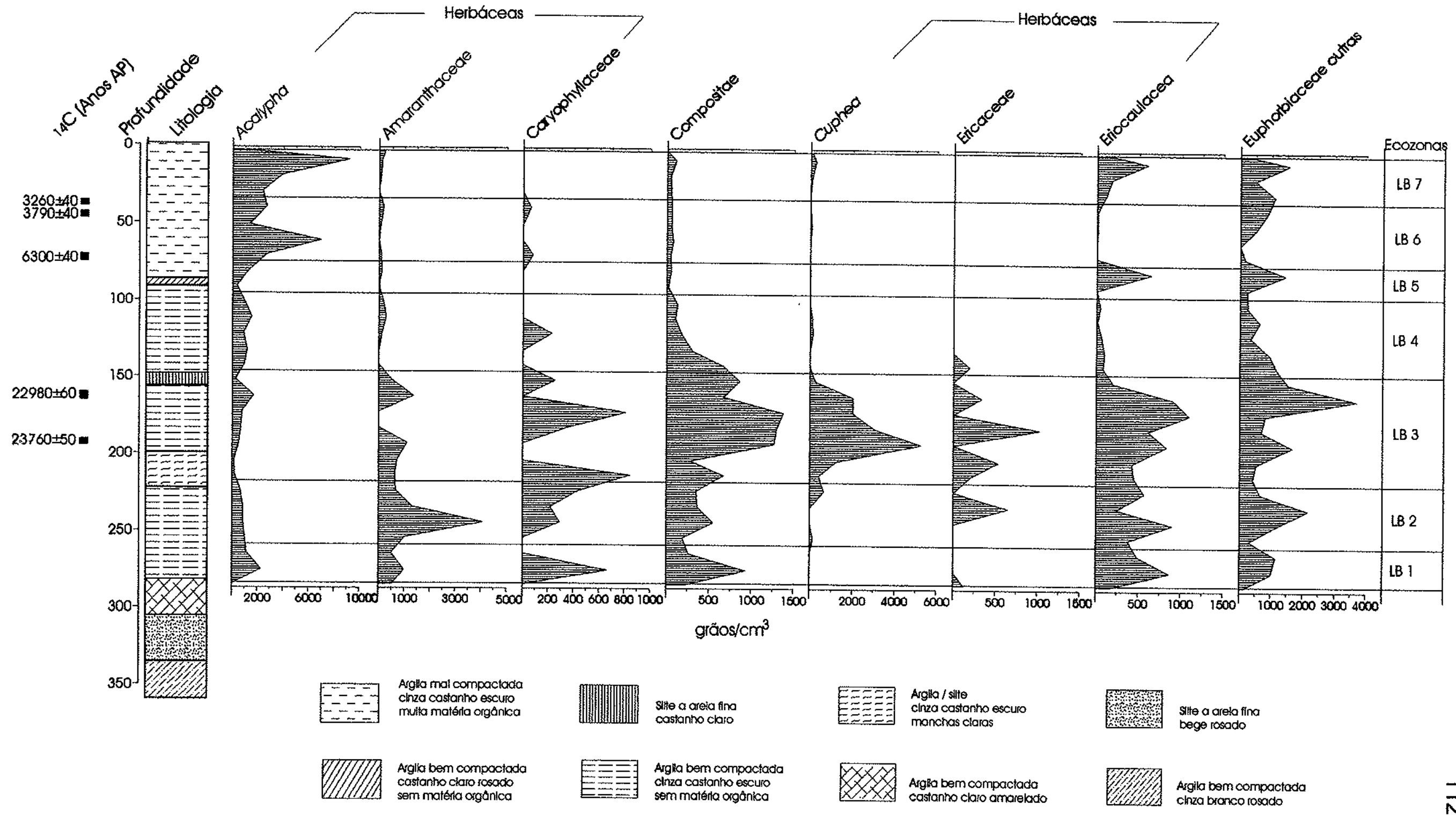

FIGURA 4.11: Diagrama de concentração de elementos herbáceos e outros elementos - I 


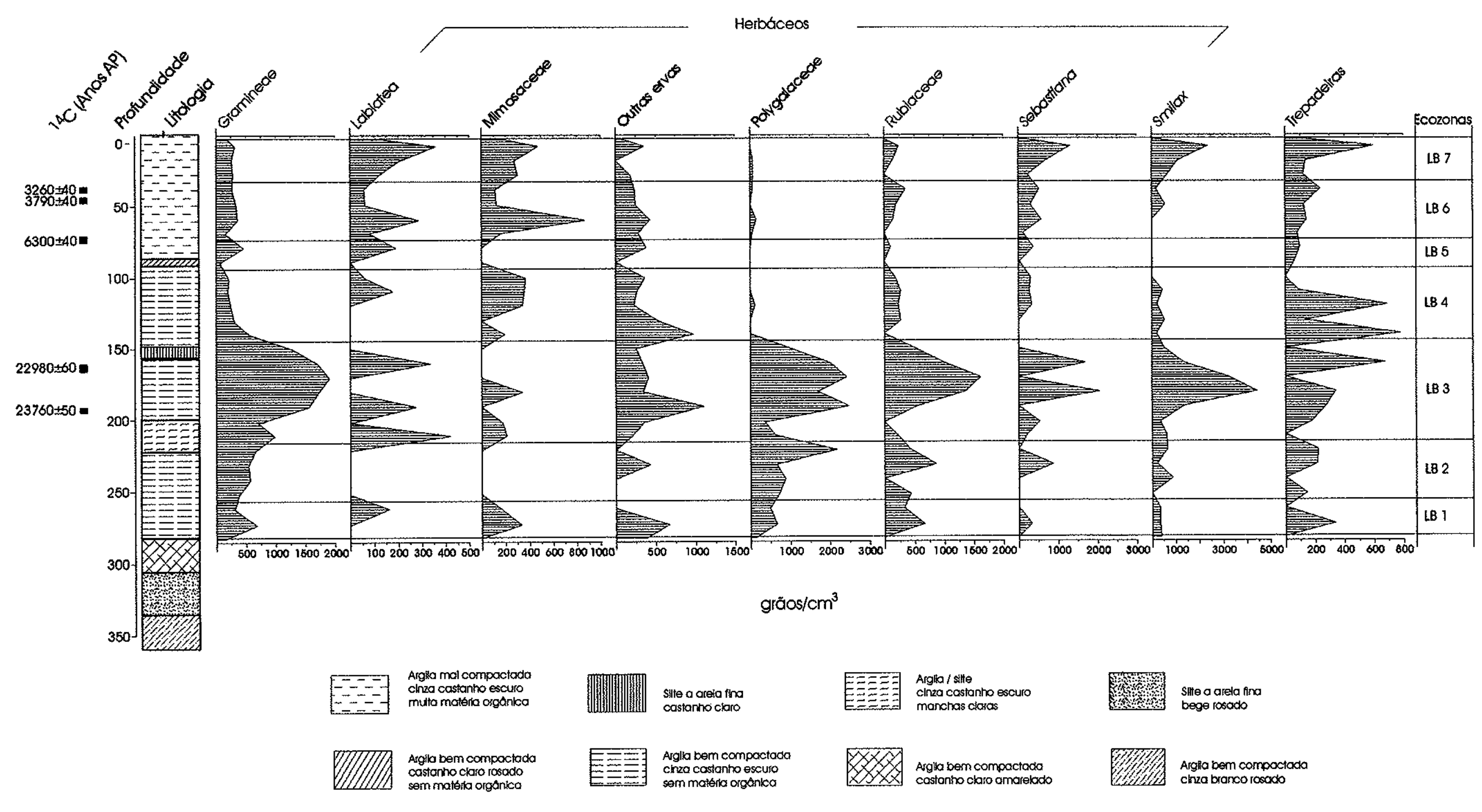

FIGURA 4.12: Diagrama de concentraçăo de elementos herbáceos e outros elementos - II 


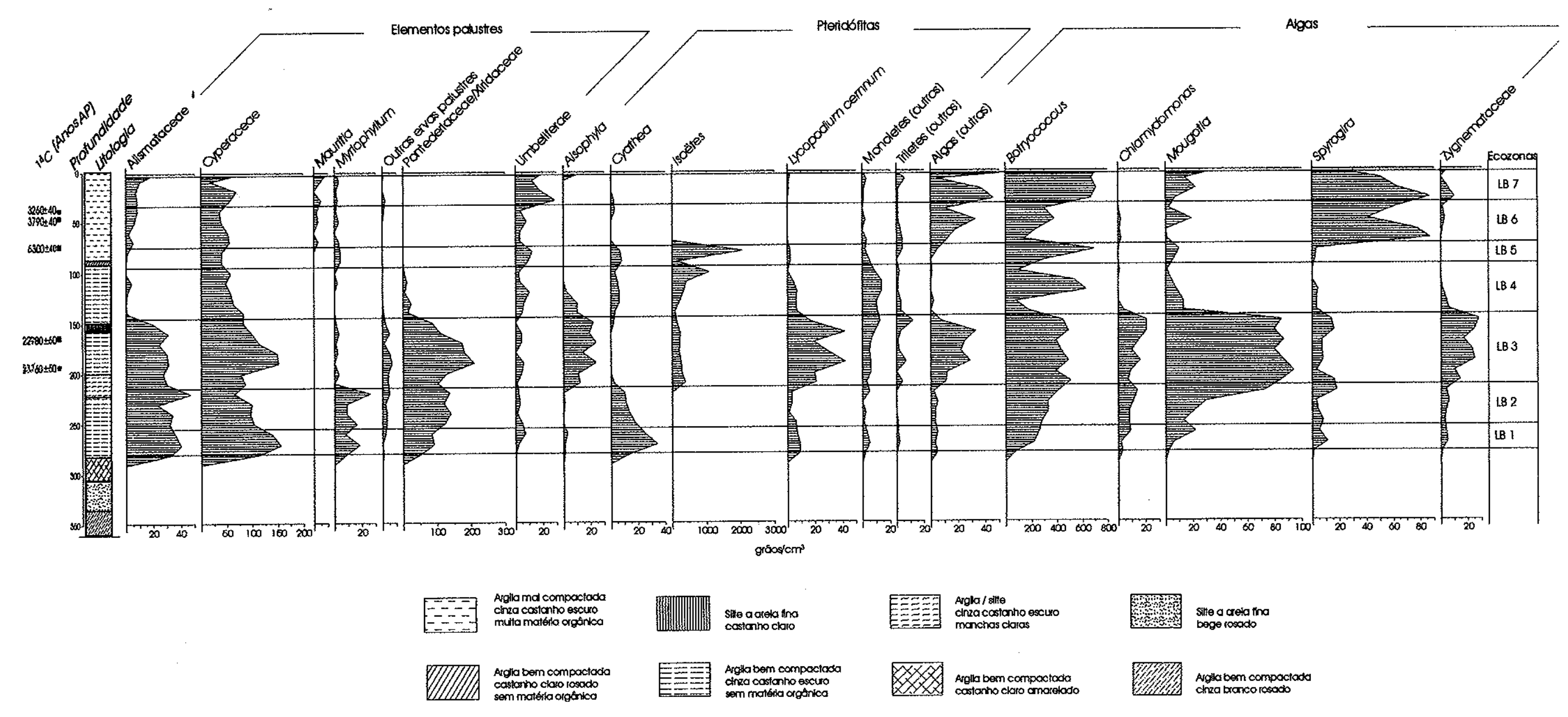

FIGURA 4.12: Diagrama de concentração de elementos palustres, Pteridófitas e algas 


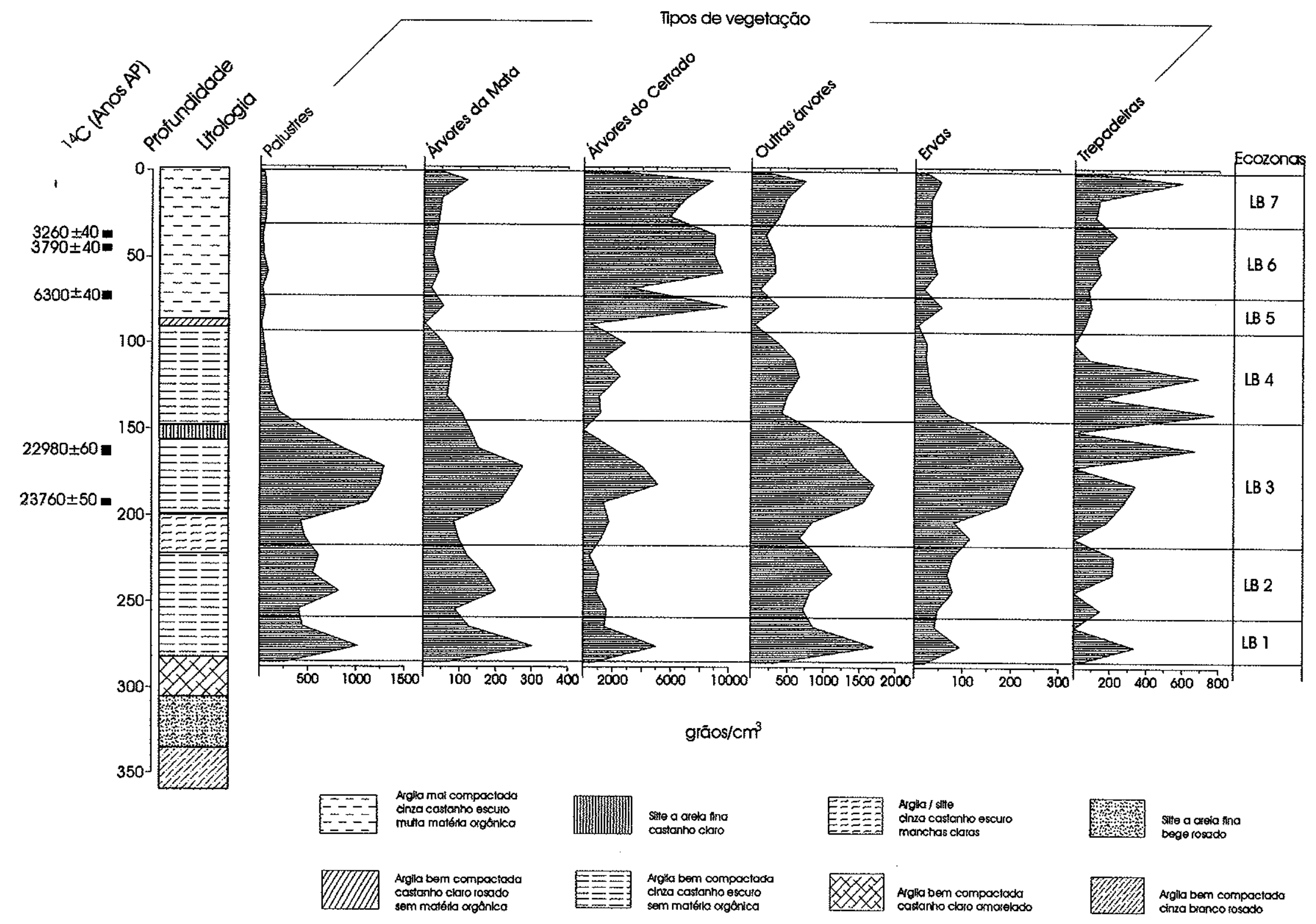

$\overrightarrow{\vec{v}}$

FIGURA 4.14: Diagrama de concentração dos tipos de vegetação 

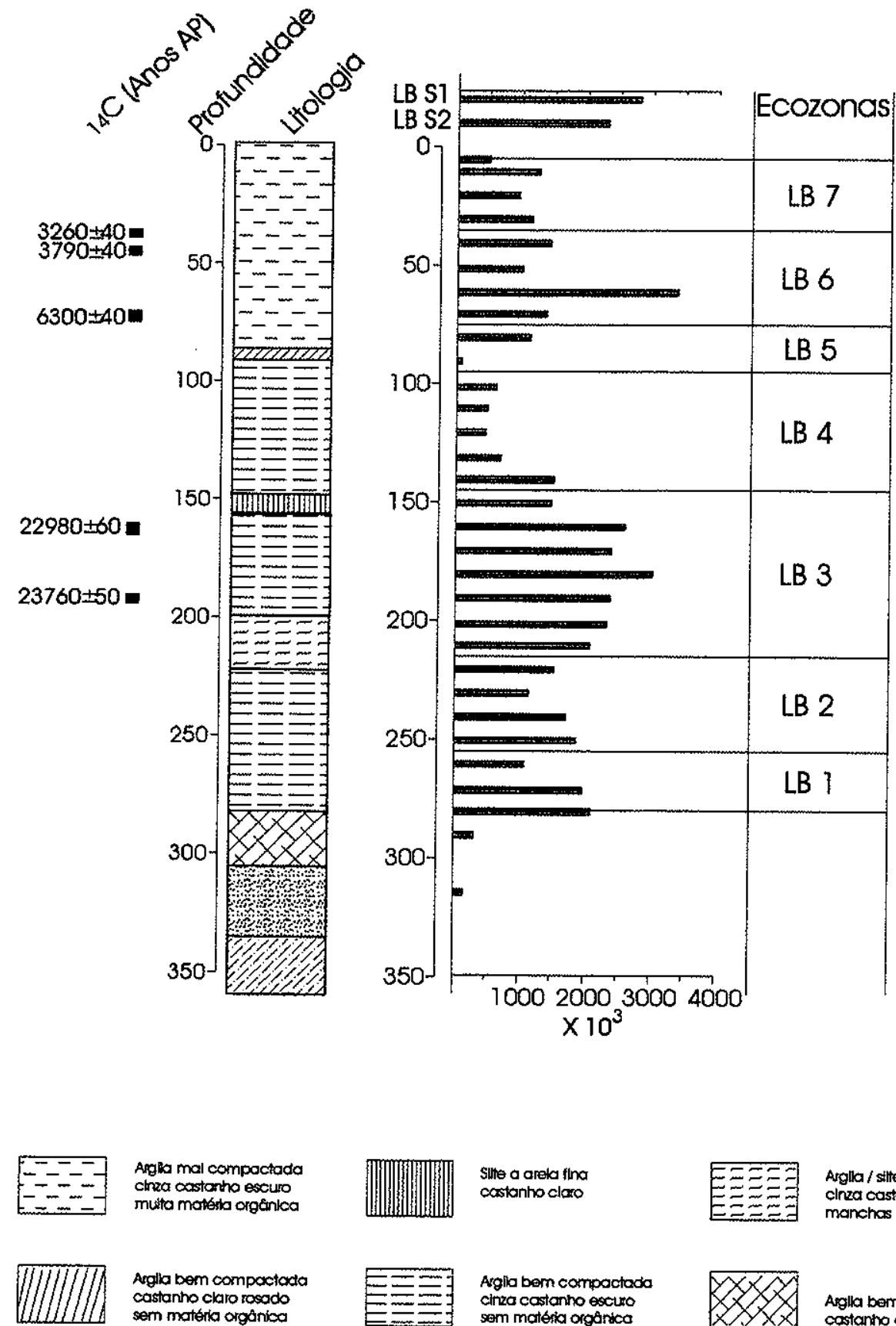

Angira mal compactada ctreca castantio escuro

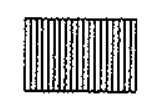

Silhe a arela fine

castanho claro

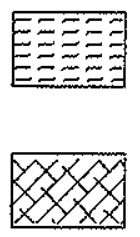

Arglla / sitte clinza castanho escuro muta motesta orgenica

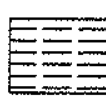

Argila bern compoctado cinza costanho escuro

costanho claro rosado sem matérika orgânica sem matésia organico 


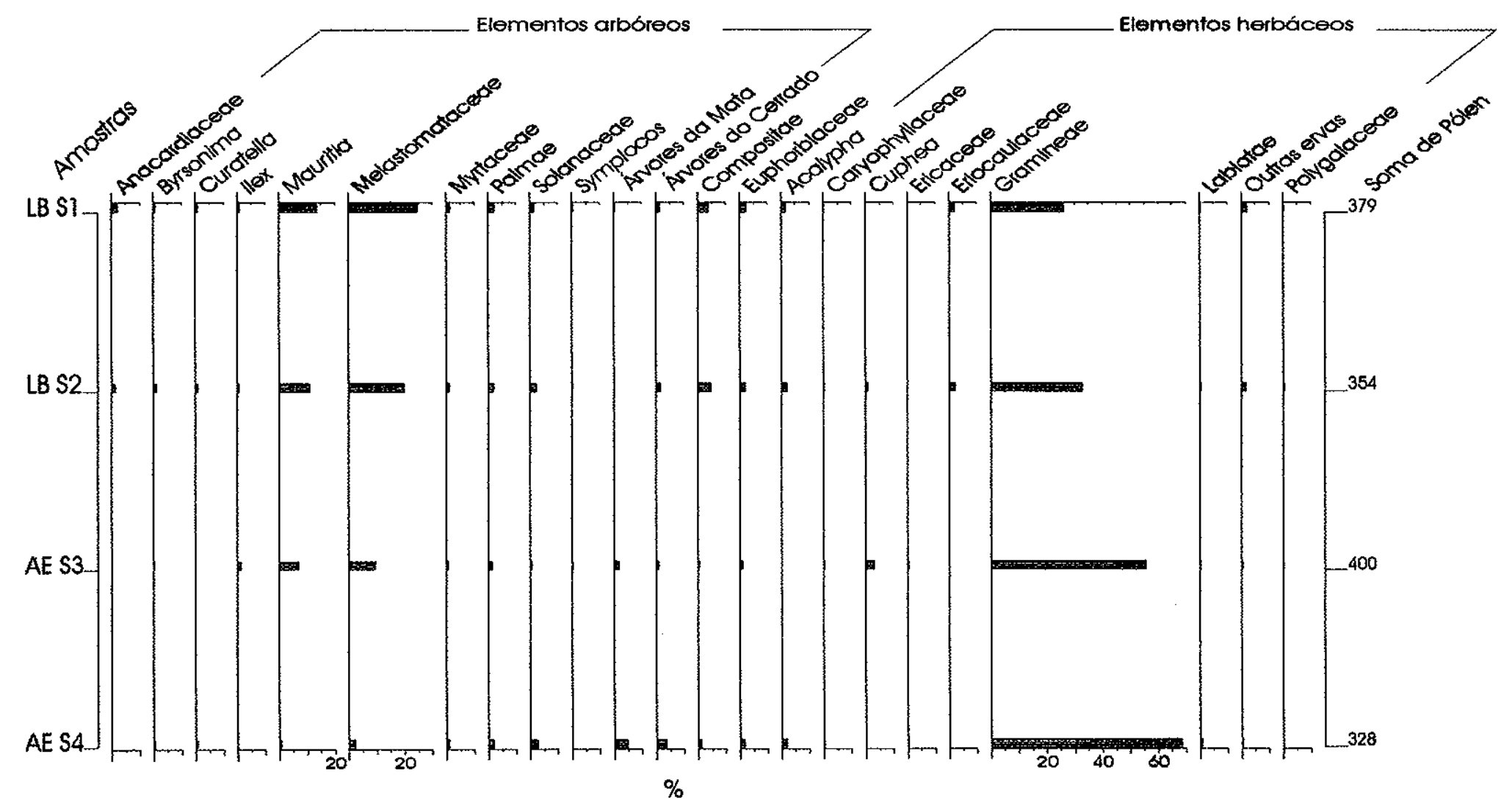

FIGURA 4.16: Histograma de porcentagem dos elementos arbóreos e herbáceos das amostras de superfície da Lagoa Bonita e da Vereda de Águas Emendadas 


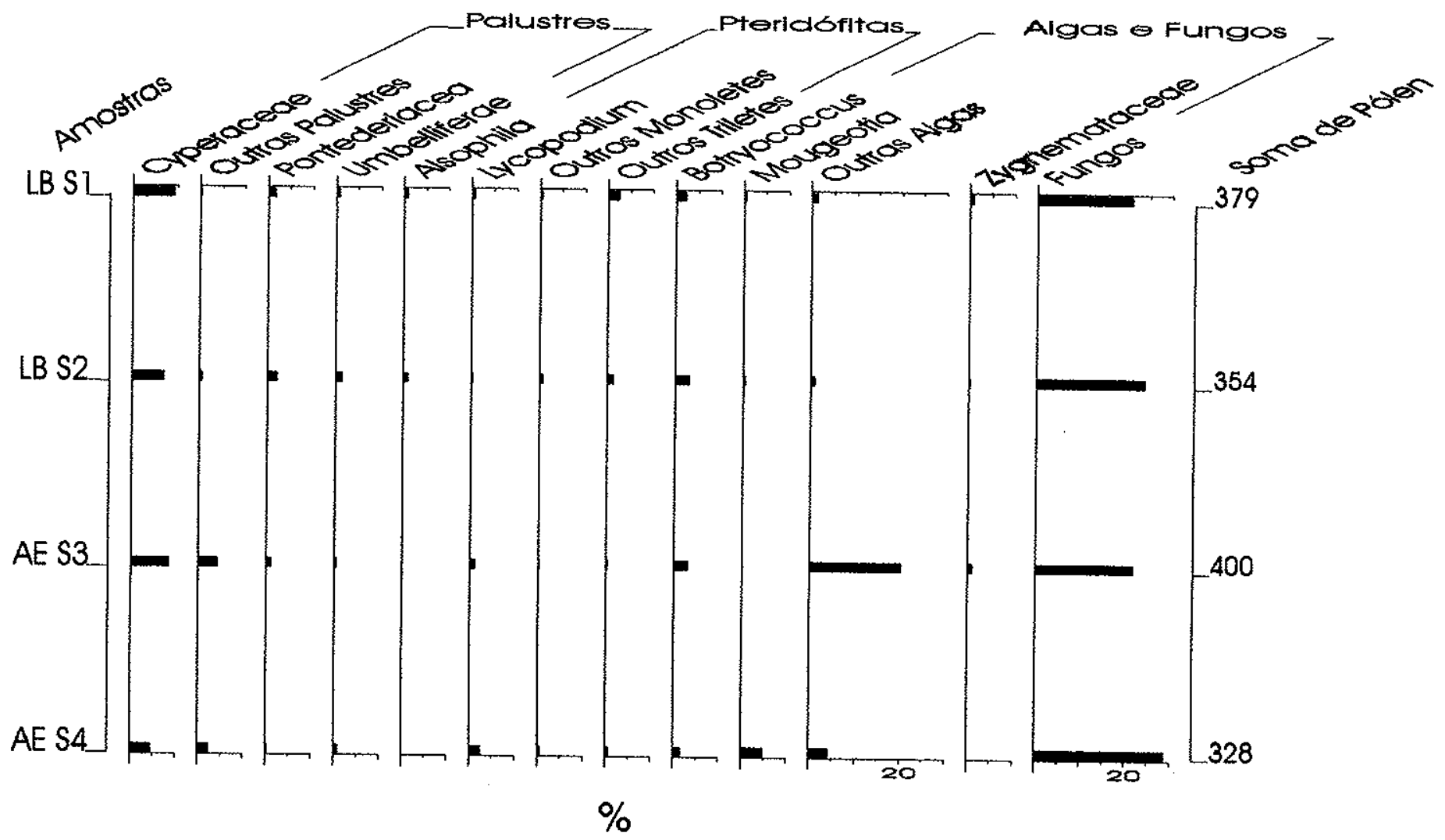

FIGURA 4.17: Histograma de porcentagem dos elementos palustres, Pteridófitas e algas das amostras de superfície da Lagoa Bonita e da Vereda de Águas Emendadas 


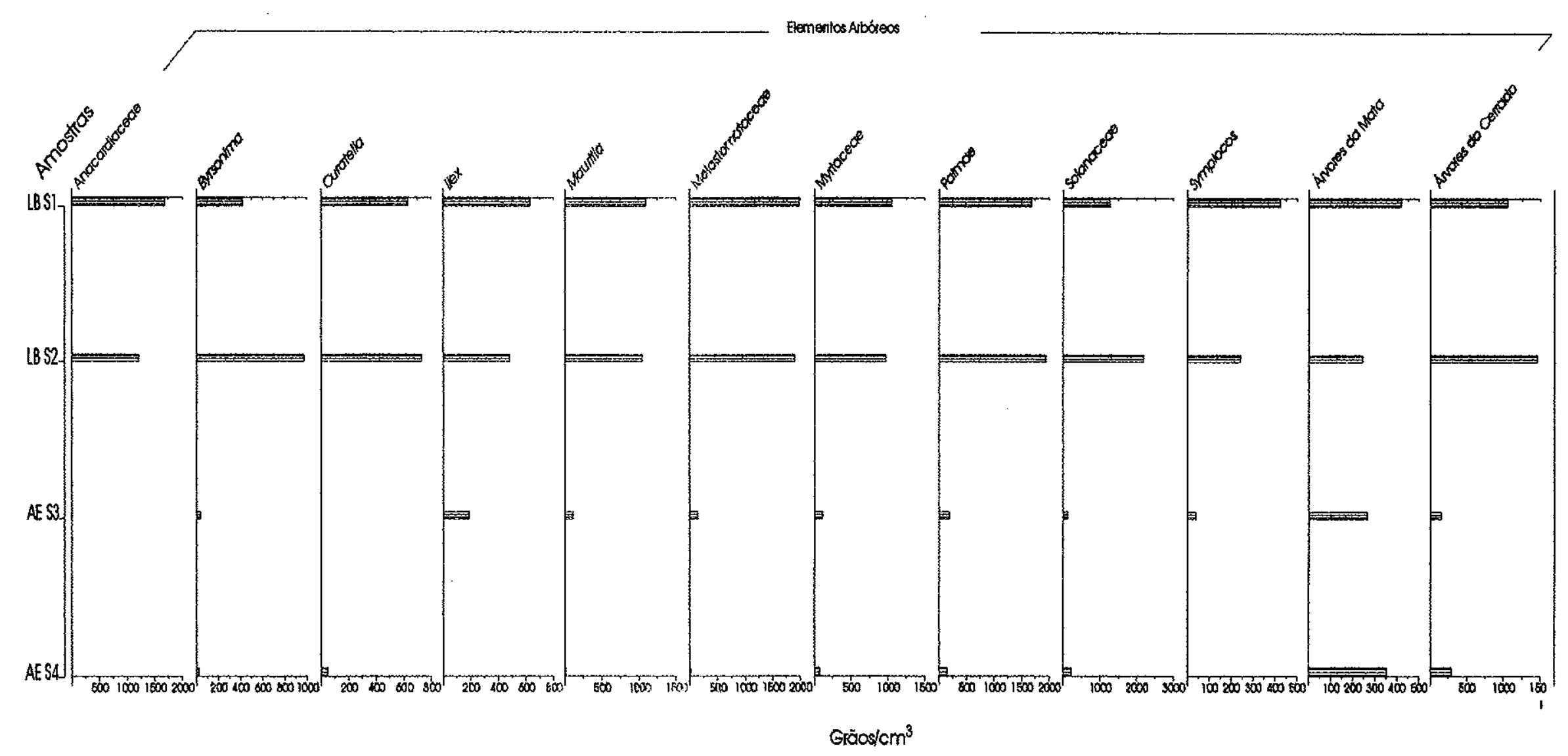

FIGURA 4.18: Histograma de concentraçăo dos elementos arbóreos das amostras de superfície da Lagoa Bonita e da Vereda de Águas Emendadas 


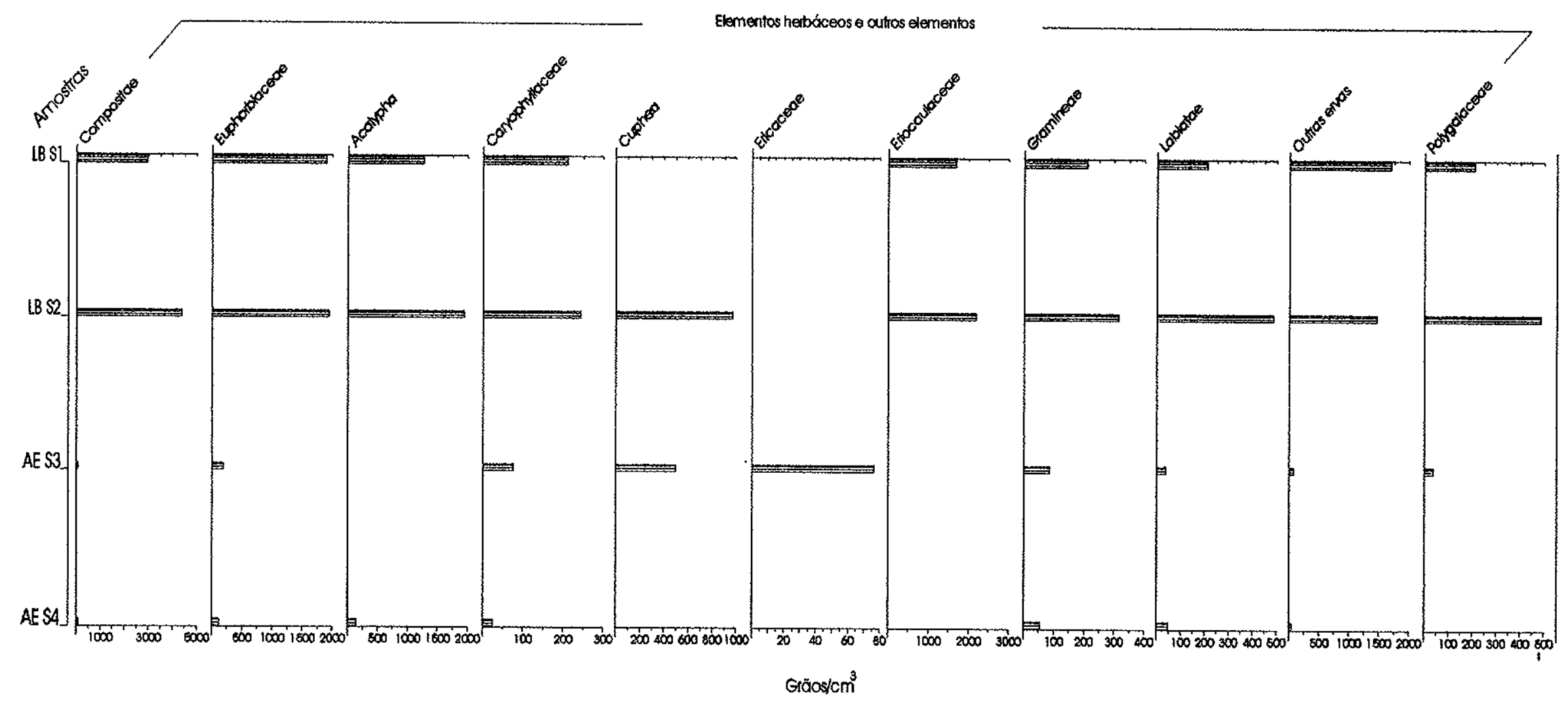

FIGURA 4.19: Histograma de concentraçăo dos elementos herbáceos e outros elementos das amostras de superfície da Lagoa Bonita e da Vereda de Aguas Emendadas 


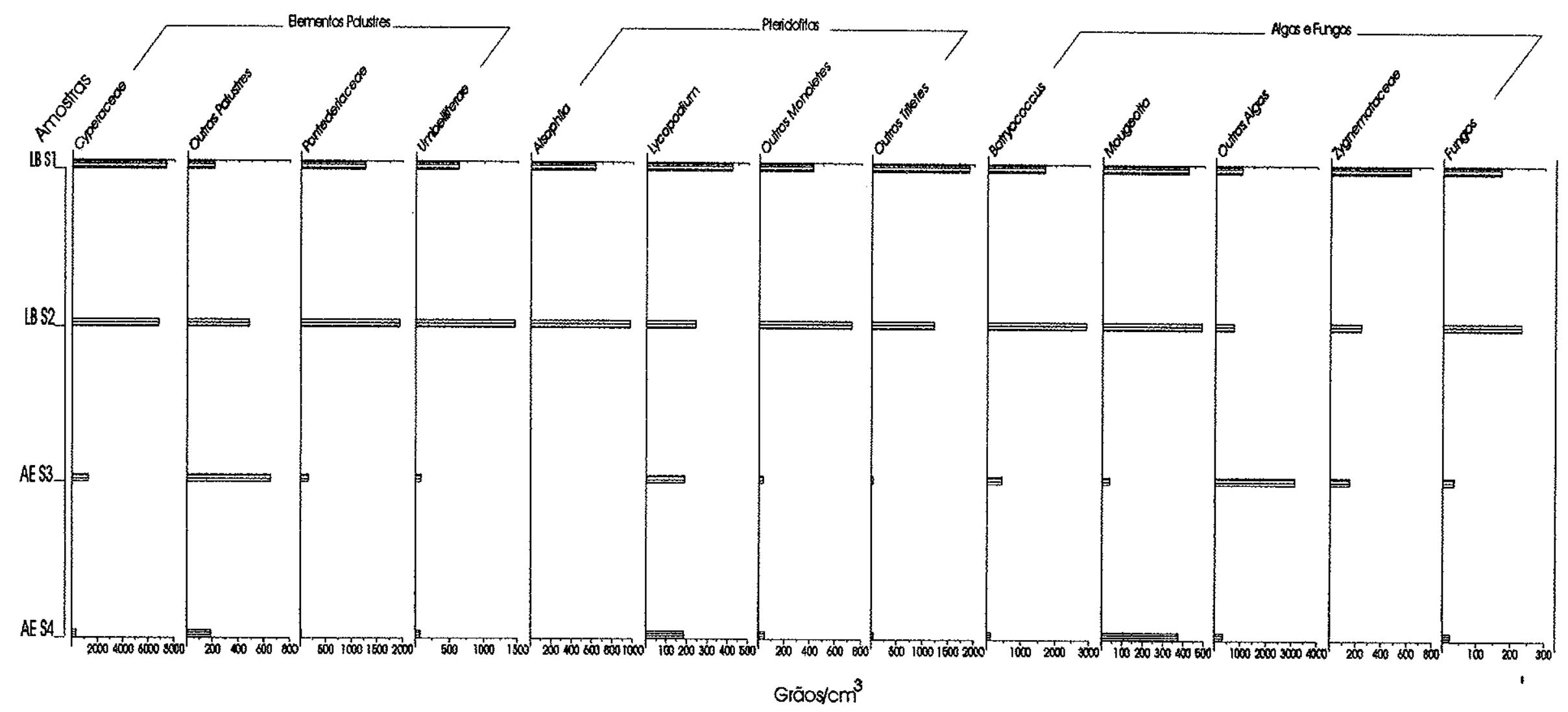

FIGURA 4.20: Histograma de concentração dos elementos palustres, Pteridófitas e algas das amostras de superfície da Lagoa Bonita e da Vereda de Águas Emendadas 


\subsection{Síntese}

O estudo palinológico e a caracterização dos argilominerais permitem reconstituir a evolução paleoambiental da área da Lagoa Bonita (DF), que mostra importantes alteraçöes qualitativas e quantitativas na vegetação em conseqüência de mudanças climáticas a partir do Quaternário tardio (Figura 4.21).

A fase anterior à instalação da lagoa foi dominada por processos de intemperismo por laterização, que atuaram sobre superficies pediplanadas de metassedimentos do Grupo Paranoá, originando um solo espesso, constituído predominantemente por caolinita e óxidos e hidróxidos de ferro e alumínio.

A formação da Lagoa Bonita no Pleistoceno tardio, ocorreu por volta de 26.000 nos AP (idade extrapolada), iniciando-se o processo de assoreamento por material detrítico proveniente do manto de intemperismo.

Uma vegetação com predomínio de elementos arbóreos, característicos de clima úmido e frio, desenvolve-se no entorno da lagoa, onde é também marcante a presença de vegetação aquática. Mesmo com pequenas oscilações nas proporções de ocorrência dos elementos florísticos, verifica-se uma tendência ao aumento da umidade e queda na temperatura, cuja culminação ocorre em torno de 22.900 anos AP, com a expansão de todos os táxons presentes, resultando em uma fitofisionomia bastante característica. Nesta época, uma formação florestal com composição diferente das matas atuais ocupava o entorno da lagoa.

Esta fase é seguida por quedas acentuadas na umidade e temperatura, características do clima provavelmente semi-árido, que foi responsável pela retração da vegetação, exposição parcial do solo e instalação de intenso processo erosivo, em torno de 19.000 anos AP (idade extrapolada), chegando a expor subaereamente metassedimentos menos intemperizados do Grupo Paranoá.

$O$ retorno da umidade e conseqüentemente da vegetação só ocorreu no Glacial Tardio (cerca de 13.000 anos AP, idade extrapolada). Sob condiçōes de clima ainda frio, porém mais ameno, desenvolveu-se uma vegetação diferente da existente durante o Pleniglacial superior.

O's elementos botânicos pioneiros e característicos do bioma Cerrado, surgiram inicialmente de forma incipiente, mas com tendência contínua de expansão durante o Holoceno. Embora tenham ocorrido oscilações na umidade, 
as temperaturas foram sempre crescentes. Há cerca de 7.900 anos AP (idade extrapolada), a lagoa adquiriu condições pantanosas pela instalação de estações secas mais prolongadas, que causaram a exposição sub-aérea e a oxidação de sedimentos de fundo.

O retorno das condições úmidas a semi-úmidas, com oscilações na umidade, acompanhado pela tendência de aumento de temperatura durante o Holoceno, levou à formação da vereda há cerca de 6.300 anos $\mathrm{AP}$, que é uma fitofisionomia caracteristica de redes de drenagem instaladas sobre superfícies aplanadas. As oscilações são registradas em ca. 5.300 anos AP, com queda na umidade, que acentuou o regime de fogo.

A partir de 3.260 anos AP foram instaladas condiçōes paleoclimáticas semelhantes às atuais, ainda com oscilações na umidade, e o registro de uma fase mais úmida por volta de 2.100 anos AP quando se dá a expansão da Vereda, mas sempre atuando no sentido de promover a distribuição das diferentes fitofisionomias reconhecidas atualmente no Bioma Cerrado.

O mosaico vegetacional formado é resultante das modificações paleoclimáticas ocorridas a partir do Pleistoceno tardio, associadas a outros fatores bióticos e abióticos e até antrópicos. Este mosaico é representado no nordeste do Distrito Federal por um Cerrado típico, juntamente com algumas áreas de Mata e Vereda próximas à rede de drenagem e um Campo Limpo Úmido no entorno da Lagoa Bonita. 

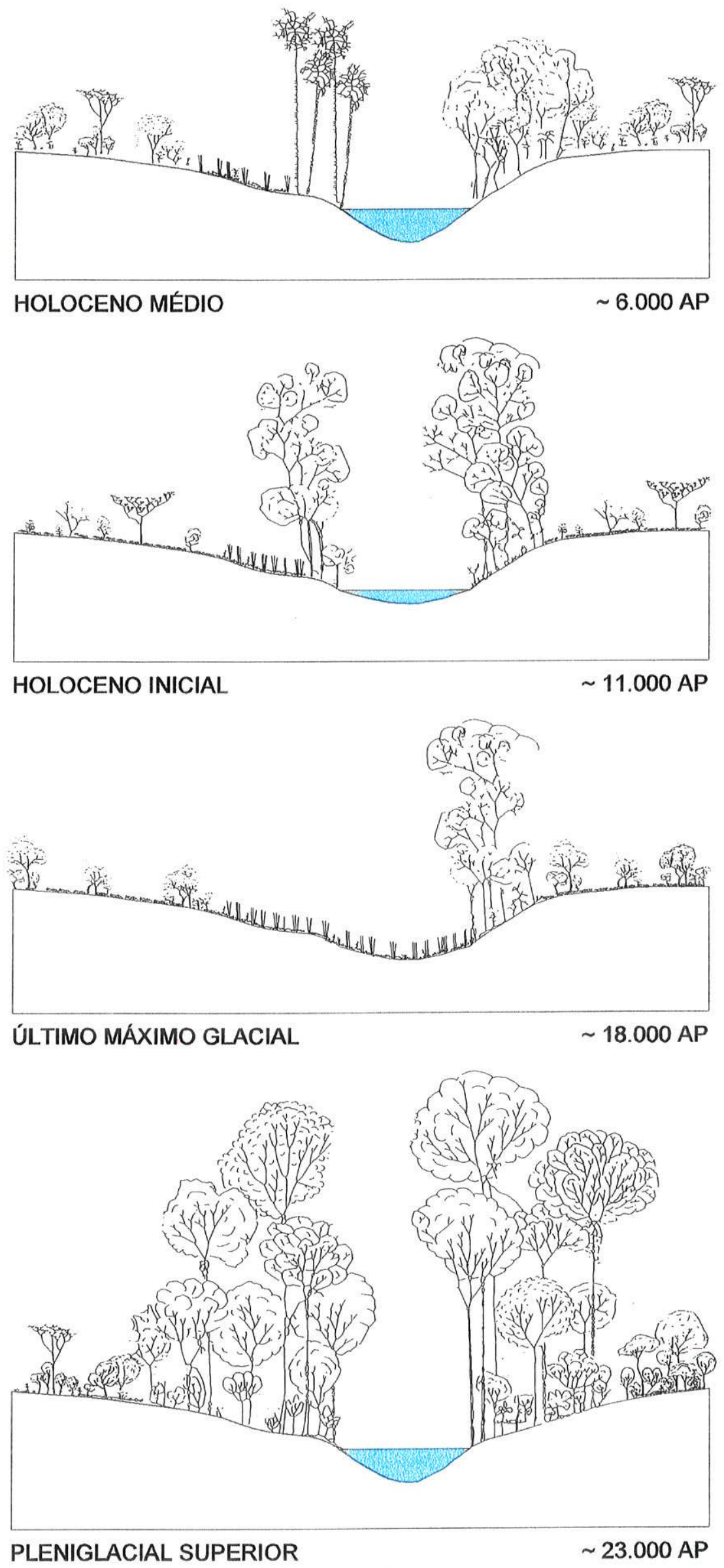

FIGURA 4.21: Perfis esquemáticos representando a evolução da paisagem na Lagoa Bonita durante o Quaternário tardio 


\section{DISCUSSÕES}

\subsection{Dados Paleoecológicos}

Os dados palinológicos do testemunho de sondagem da Lagoa Bonita, revelam mudanças marcantes na composição e na distribuição da vegetação a partir de 28.000 anos AP até o presente, os quais aliados às informações resultantes da análises dos argilominerais, indicam mudanças paleoambientais e conseqüentemente paleoclimáticas, passiveis de análises e correlações em um contexto regional.

Nas áreas de distribuição atual dos cerrados, ou próximas, há uma série de trabalhos com ênfase nos dados palinológicos que possibilitam uma comparação, visando o estabelecimento de um cenário de caráter regional para as modificações climáticas, ocorridas no Planalto Central, a partir do Pleistoceno tardio e no decorrer do Holoceno.

Os dez sítios no Brasil, com dados palinológicos provenientes da análise de sedimentos de lagos e turfas, estão localizados nas terras baixas tropicais em uma área limitada pelas latitudes de $6^{\circ}$ e $20^{\circ} \mathrm{S}$ e cerca de $52^{\circ}$ e $42^{\circ} \mathrm{W}$. Compreendem oito registros em áreas atualmente recobertas pelos cerrados e dois registros em áreas recobertas atualmente pela Floresta Amazônica e a Caatinga.

Além destes, outros sítios posicionados em latitudes norte, como o Lago de Valência situado na Cordilheira da Costa na Venezuela e a região dos Llanos na Colômbia e Venezuela, possibilitam correlações, uma vez que a vegetação regional destas áreas é representada pelas savanas que apresentam similaridades floristicas com os cerrados.

Os sítios, descritos a seguir, estão indicados na figura $5.1 \mathrm{e}$ as características fisicas, com detalhamento dos aspectos relativos ao clima e a indicação da idade absoluta mais antiga de cada registro, estão sintetizadas na tabela 5.1. 


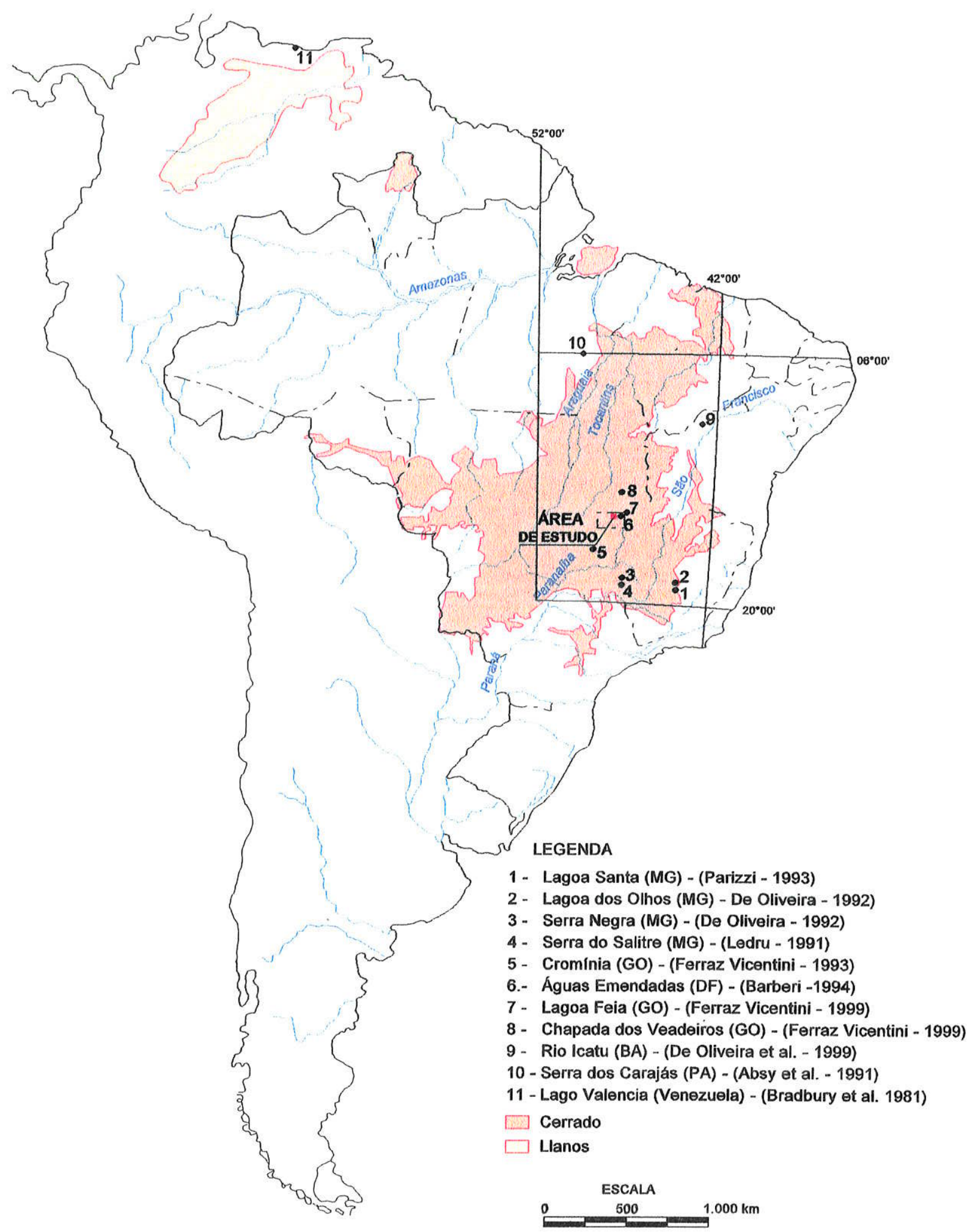

FIGURA 5.1: Mapa de localização das áreas de estudos com análises palinológicas 
TABELA 5.1: Síntese das características físicas das áreas analisadas

\begin{tabular}{|c|c|c|c|c|c|c|c|c|c|c|c|c|c|c|}
\hline \multicolumn{2}{|c|}{ Áreas Analisadas } & \multirow{2}{*}{$\begin{array}{c}\text { Localização } \\
\text { Coordenadas } \\
\text { Nordeste DF } \\
15^{\circ} 35^{\prime} \mathrm{S} \\
47^{\circ} 41^{\prime} \mathrm{W}\end{array}$} & \multirow{2}{*}{\begin{tabular}{|l|} 
Natureza \\
Lacustre
\end{tabular}} & \multirow{2}{*}{\begin{tabular}{|c|}
$\begin{array}{c}\text { Altitude } \\
\text { (m) }\end{array}$ \\
960
\end{tabular}} & \multirow{2}{*}{ 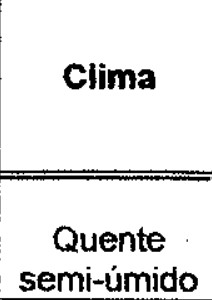 } & \multirow{2}{*}{$\begin{array}{c}\begin{array}{c}\text { Duração } \\
\text { estação } \\
\text { Seca } \\
\text { (meses) }\end{array} \\
4 \text { a } 5\end{array}$} & \multirow{2}{*}{\begin{tabular}{|c}
$\begin{array}{c}\text { Precipitaçăo } \\
\text { média anual } \\
\text { (mm) }\end{array}$ \\
1600
\end{tabular}} & \multirow{2}{*}{\begin{tabular}{|c}
$\begin{array}{c}\text { Temperatura } \\
\text { média anual } \\
\left({ }^{\circ} \mathrm{C}\right)\end{array}$ \\
22
\end{tabular}} & \multirow{2}{*}{\begin{tabular}{|c|}
$\begin{array}{c}\text { Temperatura } \\
\text { média mês } \\
\text { mais frio } \\
\text { (年) }\end{array}$ \\
18 \\
18
\end{tabular}} & \multirow{2}{*}{$\begin{array}{c}\begin{array}{c}\text { Temparatura } \\
\text { minima } \\
\text { absoluta } \\
\text { (cC) }\end{array} \\
8 \text { a } 10\end{array}$} & \multirow{2}{*}{$\begin{array}{c}\begin{array}{c}\text { Ocorréncia } \\
\text { módia de } \\
\text { geadas } \\
\text { (dias/ano) }\end{array} \\
0\end{array}$} & \multirow{2}{*}{$\begin{array}{c}\begin{array}{c}\text { Vogotação } \\
\text { local o regional }\end{array} \\
\text { Cerrado, Vereda } \\
\text { Cerrado denso } \\
\text { Área antropizada }\end{array}$} & \multirow{2}{*}{$\begin{array}{l}\begin{array}{c}\text { D. absoluta } \\
\text { mais antiga } \\
{ }^{4} \mathrm{C}\end{array} \\
(\text { anos AP) }\end{array}$} & \multirow{2}{*}{$\begin{array}{c}\begin{array}{c}\text { Fontes } \\
\text { principais }\end{array} \\
11\end{array}$} \\
\hline \multirow{5}{*}{ 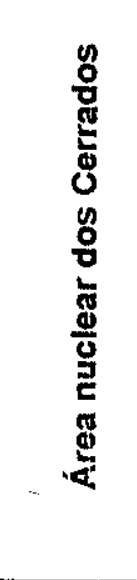 } & Lagoa Bonita & & & & & & & & & & & & & \\
\hline & Águas Emendadas & $\begin{array}{c}\text { Nordeste DF } \\
15^{\circ} 34^{\prime} \mathrm{S} \\
47^{\circ} 35^{\prime} \mathrm{W}\end{array}$ & Turfeira & 1040 & $\begin{array}{l}\text { Quente } \\
\text { semi-úmido }\end{array}$ & 4 a 5 & 1600 & 22 & 18 & 8 a 10 & 0 & $\begin{array}{l}\text { Cerrado, Vereda } \\
\text { Mata galeria } \\
\text { Area antropizada }\end{array}$ & $25.790 \pm 70$ & $2 \mathrm{e} 11$ \\
\hline & Lagoa Feia & \begin{tabular}{|c|} 
Norte/nordeste GO \\
$15^{\circ} 34^{\prime} \mathrm{S}$ \\
$47^{\circ} 18^{\prime} \mathrm{W}$ \\
\end{tabular} & Lacustre & 831 & $\begin{array}{c}\text { Quente } \\
\text { semi-úmido }\end{array}$ & 4 a 5 & 1600 & 22 & 18 & 8 a 10 & 0 & $\begin{array}{c}\text { Cerrado } \\
\text { Mata galeria } \\
\text { Area antropizada }\end{array}$ & $5.280 \pm 40$ & 7 e 11 \\
\hline & Chapada Veadeiros & $\begin{array}{c}\text { Nordeste GO } \\
14^{\circ} 10^{\prime} \mathrm{S} \\
47^{\circ} 30^{\prime} \mathrm{W} \\
\end{array}$ & Lacustre & 1400 & $\begin{array}{l}\text { Quente } \\
\text { semi-úmido }\end{array}$ & 4 a 5 & 1200 a 1550 & 22 & 18 & 4 a 8 & 0 & $\begin{array}{c}\text { Cerrado aberto } \\
\text { Campo altitude } \\
\text { Mata galeria } \\
\end{array}$ & $18.170 \pm 230$ & 7 e 11 \\
\hline & Crominia & $\begin{array}{c}\text { Sudeste GO } \\
17^{\circ} 17^{\prime} \mathrm{S} \\
49^{\circ} 25^{\prime} \mathrm{W} \\
\end{array}$ & Turfeira & 710 & $\begin{array}{c}\text { Quente } \\
\text { semi-ümido }\end{array}$ & 4 & 1750 & 22 & 18 & 4 a 8 & 0 & $\begin{array}{c}\text { Cerrado, Vereda } \\
\text { Cerrado denso } \\
\text { Floresta semi-decidua } \\
\end{array}$ & $32.390 \pm 540$ & $6 \mathrm{e} 11$ \\
\hline \multirow{2}{*}{ 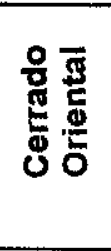 } & Lagoa Santa & $\begin{array}{c}\text { Centro/sul MG } \\
19^{\circ} 38^{\prime} \mathrm{S} \\
43^{\circ} 54^{\prime} \mathrm{W} \\
\end{array}$ & Lacustre & 740 & $\begin{array}{l}\text { Sub-quente } \\
\text { semi-úmido }\end{array}$ & 3 a 4 & 1381 & 21 & 15 a 18 & $0 a 4$ & 5 & $\begin{array}{c}\text { Cerrado } \\
\text { Floresta semi-decidua } \\
\text { Área antropizada }\end{array}$ & $6.790 \pm 140$ & $12 \mathrm{e} 11$ \\
\hline & Lagoa dos Olhos & $\begin{array}{c}\text { Centro/sul MG } \\
19^{\circ} 38^{\prime} \mathrm{S} \\
43^{\circ} 54^{\prime} \mathrm{W} \\
\end{array}$ & Lacustre & 730 & $\begin{array}{l}\text { Sub-quente } \\
\text { semi-ümido }\end{array}$ & 3 a 4 & 1381 & 21 & 15 a 18 & $0 a 4$ & 5 & $\begin{array}{c}\text { Cerrado } \\
\text { Floresta semi-decídua } \\
\text { Área antropizada }\end{array}$ & $19.520 \pm 160$ & 4 e 11 \\
\hline \multirow{2}{*}{ 倦 } & Lagoa Serra Negra & $\begin{array}{c}\text { Sudoeste MG } \\
18^{\circ} 55^{\prime} \mathrm{S} \\
46^{\circ} 50^{\prime} \mathrm{W} \\
\end{array}$ & Lacustre & 1170 & $\begin{array}{l}\text { Sub-quente } \\
\text { semi-úmido }\end{array}$ & 3 a 4 & 1600 & 21 & 10 a 15 & 0 a 4 & 5 & $\begin{array}{c}\text { Cerrado, cerradão } \\
\text { Mata galeria } \\
\text { Floresta semi-decidua }\end{array}$ & $39.930 \pm 540$ & 4 e 11 \\
\hline & Serra do Salitre & $\begin{array}{r}\text { Sudoeste } \\
19^{\circ} 00^{\prime} \mathrm{S} \\
46^{\circ} 46^{\prime} \mathrm{W} \\
\end{array}$ & Turfeira & 1050 & $\begin{array}{l}\text { Sub-quente } \\
\text { semi-úmido }\end{array}$ & 3 a 4 & 1500 & 21 & 10 a 15 & 0 a 4 & 5 & $\begin{array}{c}\text { Cerrado, cerradão } \\
\text { Floresta semi-decídua } \\
\text { Área antropizada } \\
\end{array}$ & $32.030 \pm 2020$ & 10 e 11 \\
\hline \multirow{2}{*}{ 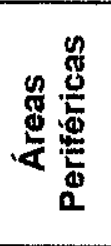 } & Serra dos Carajäs & $\begin{array}{c}\text { Leste/sudeste PA } \\
6^{\circ} 20^{\prime} \mathrm{S} \\
50^{\circ} 25^{\prime} \mathrm{W} \\
\end{array}$ & Lacustre & $\begin{array}{c}700 a \\
800\end{array}$ & $\begin{array}{l}\text { Quente } \\
\text { úmido }\end{array}$ & 3 & 1500 a 2000 & 25 & 18 & 12 a 16 & 0 & \begin{tabular}{|c|} 
Cerrado \\
Floresta semi-decidua \\
Floresta úmida \\
\end{tabular} & $51.200 \pm 1700$ & 1 e 11 \\
\hline & Turfa do Saquinho & $\begin{array}{c}\text { Norte/noroeste BA } \\
10^{\circ} 50^{\circ} \mathrm{S} \\
43^{\circ} 00^{\prime} \mathrm{W} \\
\end{array}$ & Turfeira & 500 & $\begin{array}{c}\text { Quente } \\
\text { semi-árido }\end{array}$ & 7 & 600 & 26 & 24 & 8 a 12 & 0 & \begin{tabular}{|c|} 
Caatinga \\
Vereda, Mata galeria \\
Cerrado
\end{tabular} & $10.990 \pm 80$ & 5 e 11 \\
\hline \multirow{2}{*}{ 尊 } & Lago de Valência & $\begin{array}{c}\text { Norte Venezuela } \\
10^{\circ} 11^{\prime} \mathrm{N} \\
67^{\circ} 43^{\prime} \mathrm{W} \\
\end{array}$ & Lacustre & 403 & $\begin{array}{c}\text { Quente } \\
\text { semi-úmido }\end{array}$ & 5 a 6 & 840 & 25 & - & 15 & 0 & $\begin{array}{c}\text { Savana } \\
\text { Floresta decidua } \\
\text { Área antropizada } \\
\end{array}$ & $11.825 \pm 360$ & $3 e 13$ \\
\hline & Llanos Orientais & $\begin{array}{c}\text { Venez. e Colòmbia } \\
\sim 4^{\circ} \mathrm{N} \\
\sim 70^{\circ} \mathrm{W} \\
\end{array}$ & Lacustre & $<600$ & $\begin{array}{c}\text { Quente } \\
\text { semi-úmido }\end{array}$ & 4 a 5 & 1200 a 1800 & 25 & - & 10 a 15 & 0 & $\begin{array}{c}\text { Savana, campo } \\
\text { Vereda, Mata galeria } \\
\text { Área antropizada }\end{array}$ & $18.290 \pm 90$ & 8 e 9 \\
\hline
\end{tabular}

Fontes: 1. Absy et al., 1991; 2. Barberi, 1994; 3. Bradbury et al., 1981; 4. De Oliveira, 1992; 5. De Oliveira et al., 1999; 6. Ferraz-Vicentini, 1993;

7. Ferraz-Vicentini, 1999; 8. Hooghiemstra \& van der Hammen, 1998; 9. Hooghiemstra \& van der Hammen, 1999; 10. Ledru et al. 1996;

11. Nimer, 1989; 12. Parizżi, 1993; 13. Salgado-Labouriau, 1980 
Os oito sítios recobertos atualmente pela vegetação dos cerrados, com estudos de caráter palinológico e paleoecológico, estão posicionados em altitudes entre $700 \mathrm{~m}$ e $1400 \mathrm{~m}$ e em áreas onde a precipitação média anual se situa entre 1300 e $1800 \mathrm{~mm}$. Além das análises palinológicas, alguns sítios apresentam também dados referentes às análises mineralógicas, geoquímicas, do conteúdo de matéria orgânica e de partículas de carvão.

Compreendem as localidades de Lagoa da Serra Negra (De Oliveira, 1992) e Lagoa Campestre na Serra do Salitre (Ledru, 1991; 1993; Ledru et al., 1994; 1996), Lagoa Santa (Parizzi, 1993, Parizzi et al., 1998) e Lagoa dos Olhos (De Oliveira, 1992) na região de Lagoa Santa, Cromínia (Ferraz-Vicentini, 1993; Salgado-Labouriau \& Ferraz-Vicentini, 1994; Ferraz-Vicentini \& SalgadoLabouriau, 1996), Lagoa Feia, Chapada dos Veadeiros (Ferraz-Vicentini, 1999) e Vereda de Águas Emendadas (Barberi 1994; 1998; Barberi et al., 1995; 2000) na área nuclear dos cerrados.

Para a área de Crominia, os estudos incluem também a geomorfologia e análise geoquímica dos sedimentos e partículas de carvão (Salgado-Labouriau et al., 1997). Para a área da Serra do Salitre as informações paleoecológicas baseiam-se também nas análises do conjunto de fitólitos no solo (Alexandre et al., 1999), mineralógica (Bertaux et al., 1996) e do conteúdo de fragmentos de carvão (Vernet et al., 1994). Sínteses para as áreas de ocorrência dos cerrados foram apresentadas por Salgado-Labouriau (1997) e Ledru et al., (1998).

Entre as áreas citadas, as localidades de Lagoa de Serra Negra e Lagoa Campestre na Serra do Salitre, situam-se nas mais altas latitudes e mais próximas ao contato dos cerrados com a Mata Tropical Úmida e áreas intensamente antropizadas.

A Lagoa dos Olhos e a Lagoa Santa, estão posicionadas nas menores longitudes, portanto na porção mais oriental da área de distribuição dos cerrados e mais próximas ao contato com a Mata Úmida Tropical e a Mata Atlântica. As áreas de Cromínia, Chapada dos Veadeiros, Lagoa Feia, Águas Emendadas e a área de estudo, Lagoa Bonita, estão situadas na denominada área nuclear dos cerrados.

Cabe ressaltar que a Vereda de Águas Emendadas dista aproximadamente $10 \mathrm{~km}$ em direção a leste da Lagoa Bonita e está inserida no mesmo contexto 
regional, quanto aos aspectos de geologia, relevo, solo e clima o que possibilita a caracterização das modificações paleoambientais para uma área um pouco mais abrangente.

A característica marcante e diferenciada com relação aos outros locais estudados é a posição destes dois sítios na região do divisor das grandes bacias hidrográficas brasileiras, o que pode ter facilitado a chegada de táxons de diferentes áreas e eventualmente de outros biomas, a partir da expansão das florestas de galerias em períodos mais úmidos (Oliveira-Filho \& Ratter, 1995).

As outras duas áreas, já citadas, que possibilitam correlaçōes importantes para o enfoque deste trabalho são representadas pela Serra dos Carajás, situada na Amazônia oriental, e a Turfa do Saquinho, localizada no sistema de dunas fixadas do Médio São Francisco, na porção noroeste do estado da Bahia.

A Serra dos Carajás corresponde a um platô posicionado a $700 \mathrm{~m}$ de altitude com registro de precipitação média anual entre 1500 e $2000 \mathrm{~mm}$, mais baixa que nas regiōes adjacentes $(2000$ a $3000 \mathrm{~mm})$. $O$ topo do platô é recoberto pelos cerrados com gradações entre cerrado aberto arbustivo e cerrado arbustivo denso, com a floresta úmida densa ocorrendo nas encostas do platô.

Os dados do testemunho de sondagem obtido do sedimento lacustre no platô, foram apresentados por Soubiès et al. (1991) e o material foi estudado com diversos enfoques que incluem análises litológicas e geoquímicas (Cordeiro, 1995) e do conteúdo de partículas de carvão (Turcq et al., 1998).

A análise palinológica desta seqüência apresenta registro a partir de ca. 60.000 anos AP (idade extrapolada), mostrando que no conjunto polínico atual da área há predomínio de elementos arbóreos provenientes da floresta que circunda o platô (Absy et al., 1991; Absy, 1996). Sínteses para a região da Serra dos Carajás e a Amazônia foram apresentadas por van der Hammen \& Absy (1994) e Suguio et al. (1996).

A outra área com características distintas, corresponde à região do vale do Rio Icatu, um afluente de caráter perene da margem esquerda do Rio São Francisco. Está localizada no sistema de dunas fixadas do Médio Rio São Francisco (BA) estudado por Barreto (1996; Barreto et al., 1996), onde a Turfa do Saquinho foi analisada do ponto de vista palinológico por De Oliveira et al. (1999). 
O clima da regiâo é classificado como quente e semi-árido, com precipitação média anual entre 400 e $800 \mathrm{~mm}$.

Atualmente a vegetação da área é representada pela vereda limitada por uma estreita faixa de floresta de galeria semi-decídua junto ao vale do Rio Icatu, e por caatinga arbórea e o cerrado localmente, responsáveis pela fixação das dunas nas áreas adjacentes. O registro palinológico inicia-se por volta de 11.000 anos AP.

As áreas situadas em latitudes norte, compreendem os Llanos, cujos dados possibilitam correlações paleoecológicas a partir de ca.18.000 anos AP, quando se iniciam os registros palinológicos e o Lago de Valência.

As análises e as interpretações paleoecológicas de cinco lagoas estudadas na região dos Llanos Orientais da Colômbia, foram sintetizados por Behling \& Hooghiemstra (1998; 1999). Os sítios analisados incluem as lagoas Angel, Sardinas, El Pinal e Carimagua. Situam-se próximas às coordenadas em torno de $4^{\circ} \mathrm{N}$ e $70^{\circ} \mathrm{W}$, na porção central a centro-leste dos Llanos. A distância máxima entre as lagoas é da ordem de $200 \mathrm{~km}$ e a menor distância da Cordilheira Leste é de ca. $300 \mathrm{~km}$.

A área dos Llanos está posicionada em altitudes abaixo de $600 \mathrm{~m}$ e é caracterizada por um clima sazonal com um período seco bem marcado de 4 a 5 meses, entre novembro e março, e precipitação média anual entre 2800 a 1200 $\mathrm{mm}$, a qual apresenta um gradiente, decrescendo da parte sul próximo à Amazônia colombiana em direção ao norte, na borda venezuelana dos Llanos.

A vegetação dos Llanos é representada pelas savanas em diferentes gradientes com savanas abertas, herbáceas, arbustivas e arbóreas e florestas de galerias ao longo dos rios, além de conjuntos de palmeiras como Mauritia e Mauritiella ao redor de algumas lagoas. Segundo Cuatrecasas (1989, apud Behling \& Hooghiemstra, 1999) táxons característicos dos Llanos são representados, entre os elementos herbáceos pela família Gramineae, arbustos da família Melastomataceae e árvores como Curatella e Byrsonima.

$\mathrm{Na}$ Venezuela, o Lago de Valência, também situado em uma região de savanas e matas decíduas, em muitas partes perturbadas por agricultura e desenvolvimento industrial, foi objeto de estudo com análises geoquímicas e de 
microfósseis incluindo pólen, esporos, diatomáceas, ostracodes e outros restos animais (Salgado-Labouriau, 1980; Bradbury et al., 1981).

O lago, posicionado a $427 \mathrm{~m}$ de altitude em uma depressão tectônica próxima à Cordilheira da Costa, é provavelmente do início do Quaternário, porém só foram estudados os sedimentos dos últimos 13.000 anos AP. O clima ao redor do lago é tropical quente semi-úmido, com uma longa estação seca e precipitação média anual de ca. $840 \mathrm{~mm}$, com decréscimo de temperatura e aumento de umidade acompanhando a elevação nas montanhas ao redor.

A análise dos dados paleoecológicos das diferentes áreas citadas, mostra que, no período anterior ao início do registro da Lagoa Bonita (ca. de 28.000 anos AP) e da Vereda de Águas Emendadas (ca. de 26.000 anos AP), há informações principalmente das áreas situadas próximas aos limites norte e sul da ocorrência atual dos cerrados.

No platô da Serra dos Carajás, atualmente recoberto pelos cerrados, os dados alcançam por volta 60.000 anos AP (idade extrapolada), no início do Pleniglacial Médio. Nesta fase os registrus mostram a retração da floresta úmida e a expansão de táxons dos cerrados com marcante dominância de Gramineae, sugerindo um desaparecimento total ou ao menos parcial da floresta das encostas do platô. Esta fase é seguida, em torno de $51.200 \pm 1.700$ anos AP, por uma expansão da floresta, registrada pela porcentagem elevada de elementos arbóreos, com presença bem marcada de llex e posterior período de retração da floresta por volta de 40.000 anos AP.

$\mathrm{Na}$ Serra dos Carajás, o final do Pleniglacial Médio e o Pleniglacial Superior, no intervalo entre 36.000 a 22.800 anos AP, é marcado pelo domínio do pólen arbóreo com a presença de llex, pólen de gramineas em valores mínimos e abundantes fragmentos de madeira carbonizada, indicando a presença da floresta no platô (Absy et al., 1991; Absy, 1996)

Os outros sítios com registros no Pleniglacial Médio são a Lagoa Campestre na Serra do Salitre e a Lagoa da Serra Negra, situadas no extremo sul das áreas dos cerrados, além do sítio de Cromínia, na área nuclear dos cerrados, a partir do final do Pleniglacial Médio.

$\mathrm{Na}$ Serra do Salitre, o registro anterior a 32.000 anos AP não apresenta datações absolutas, porém é sugerida, por volta de 50.000 anos AP, a partir da 
frequêencia muito baixa de pólen arbóreo e do domínio das gramíneas, uma vegetação semelhante à encontrada atualmente nas estepes da Patagônia, ao redor de um pântano sem vegetação aquática, em condições de clima muito frio e seco.

Esta fase com pequenas oscilações na umidade e com registro de interrupção na sedimentação é seguida por um aumento gradual da umidade por volta de 45.000 a 33.000 anos AP, atingindo o máximo em torno de 35.000 anos $\mathrm{AP}$, o que é inferido a partir do aumento de árvores semi-decíduas, a presença de elementos tolerantes ao frio como Araucária, além do aparecimento de táxons aquáticos. O período mais úmido de Salitre é relacionado à incursão do ar polar úmido e frio, devido ao deslocamento da Frente Polar para latitudes menores durante o período glacial (Ledru et al., 1996).

A primeira datação absoluta alcança a idade de ca. 32.000 anos AP e marca o início de uma fase separada da seqüência anterior muito úmida, por um hiato na sedimentação. No final do Pleniglacial Médio entre 32.000 e ca. 28.740 anos AP a presença de espécies montanas e de terras baixas indica uma floresta alagada sazonalmente em um clima frio. Árvores que eram freqüentes na fase úmida anterior como Alchornea, são substituídas por elementos como llex, Podocarpus e Rapanea associados atualmente à floresta de Araucária e à condições climáticas úmidas e frias (Ledru et al., 1996).

$\mathrm{Na}$ Lagoa da Serra Negra próxima a Salitre, no período anterior à 40.000 anos AP há registros de três fases de intenso resfriamento sincrônicas com altos niveis de umidade, onde a presença de elementos como Araucária, Podocarpus, llex e Rapanea, sugerem a expansão da Floresta de Araucária sob condições de temperatura ca. 7 a $9^{\circ} \mathrm{C}$ mais baixas que as atuais.

O período de 39.930 a ca. 20.000 anos AP foi caracterizado por um clima genericamente frio e úmido com um clima mais sazonal por volta de 30.000 e de 20.000 anos AP, porém com umidade suficiente para manter os principais tipos de florestas nas encostas da Serra Negra. Este periodo é interpretado como uma fase onde o resfriamento glacial pronunciado era permeado com fases mais secas forçando oscilações na vegetação (De Oliveira, 1992).

Em Cromínia, mais próxima à área de estudo, o registro se inicia ao final do Pleniglacial Médio, com indicação de que no período anterior a 32.400 anos AP 
uma vereda com uma floresta de galeria ocupavam o local, enquanto um cerrado arbóreo ocorria na região ao redor, marcando um clima semi-úmido semelhante ao atual. No período entre 32.000 e ca. 27.000 anos AP há indícios de queda na umidade e temperatura, quando a vereda é substituída por um pântano.

A fase seguinte, entre 27.000 e ca. 20.000 anos AP, é marcada pelo aumento gradativo de pólen arbóreo, porém não de Mauritia, e a presença marcante de elementos aquáticos, indicando um clima mais frio e úmido que a fase anterior. Um lago substitui novamente o pântano da fase anterior, com uma mata ao redor e vegetação regional de campo (Ferraz-Vicentini, 1993).

Portanto, ao final do Pleniglacial Médio e início do Pleniglacial Superior, por volta de 28.000 anos AP, quando do início da formação da Lagoa Bonita e do registro palinológico, e posteriormente o registro da Vereda de Águas Emendadas em ca. 26.000 anos AP, os dados provenientes das demais áreas indicam condições regionais mais frias e úmidas que as atuais, porém com oscilações na umidade.

Esta fase que se estende durante o Fleniglacial Superior está bem registrada na Lagoa Bonita e corresponde às ecozonas LB 1, LB 2 e LB 3, com a instalação da lagoa na ecozona LB 1, seguida de uma fase, por volta de 25.000 anos AP, que corresponde à ecozona LB 2, de queda de umidade marcada pelo declínio dos elementos arbóreos, caracterizando as oscilações.

As condições frias e gradativamente mais úmidas que correspondem à ecozona LB 3, atingem o máximo na Lagoa Bonita por volta de 22.900 anos AP quando se dá a expansão de todos os taxons presentes, os registros máximos de indicadores de frio como llex, Podocarpus e Hedyosmum, além dos maiores valores de Pontederiaceae/Xyridaceae indicando aumento na umidade. Em Águas Emendadas, o máximo da umidade ocorre por volta de 22.300 anos AP, marcado pelo desenvolvimento da mata de galeria, porém sem elementos de vereda como Mauritia, e do cerrado arbóreo regionalmente (Barberi, 1994).

A dimensão continental desta fase marcada por queda na temperatura e aumento na umidade, que se estende no Pleniglacial Superior entre ca. 27.000 e 23.000 anos AP, pode ser avaliada a partir da análise dos dados provenientes da região norte dos Andes e dos Andes tropicais, sintetizados por van der Hammen 
(1974; 1991), van der Hammen et al. (1992) e Hooghiemstra \& van der Hammen (1993).

A parte inferior do Pleniglacial Superior, quando se inicia o registro da Lagoa Bonita é marcada na região andina por extensos depósitos flúvio-glaciais e a expansão da floresta andina sob condições de baixa temperatura e alta umidade que se estendem localmente até ca. 23.000 anos AP.

A fase seguinte do último glacial, se inicia na Cadeia oriental por volta de 26.000 anos AP, quando o lago da Savana de Bogotá secou, indicando mudanças marcantes nas condiçōes gerais. Por volta de 21.000 anos AP o clima se torna extremamente frio e seco, com quedas na temperatura da ordem de 6 a $8^{\circ} \mathrm{C}$, além de precipitação anual com valores menores que a metade dos valores atuais. Como conseqüência, na região andina muitos lagos secam, a linha de árvores se posiciona em ca. $1500 \mathrm{~m}$ e os glaciais a $3000 \mathrm{~m}$ atingindo o máximo da sua expansão (van der Hammen, 1991).

$\mathrm{Na}$ área de estudo, após o máximo de diversidade e concentração dos tipos polínicos que marca a ecozona LB 3 em 22.900 anos AP, observa-se uma tendência ao declínio de todos os tipos, atingindo concentrações muito baixas de todos os palinomorfos no topo desta ecozona, por volta de 19.700 anos, o que resultou na retração da vegetação e a exposição do solo, fato registrado também na Vereda de Águas Emendadas por volta de 21.000 anos AP.

Em ambas as áreas há registros de deposição detrítica e de contatos erosivos que poderiam ter erodido parte do sedimento orgânico. Estas idades estão inseridas no contexto do Último Máximo Glacial (UMG), iniciado por volta de 20.000 a 18.000 anos AP, que marca uma fase de modificações marcantes nos registros.

Nas demais áreas também há informações de alterações durante o UMG. Para os sitios analisados na região dos Llanos Orientais o registro mais antigo, que corresponde à Lagoa EI Pinal, inicia-se durante o UMG por volta de 18.000 anos AP com a presença de um lago raso efêmero. O predomínio de savana aberta no entorno com marcada presença de gramíneas, muito poucas árvores, ausência de pólen aquático e queimadas freqüentes, indica que a proporção de floresta de galeria era muito pequena. 
Estas condições de clima mais seco que o atual, vigoram durante o UMG e - Glacial tardio com a mudança para condições mais úmidas a partir do final do Glacial tardio e início do Holoceno por volta de 10.500 AP. Estas mudanças são evidenciadas na Lagoa El Pinal pela instalação de um lago permanente e um pequeno aumento da área florestada, além da implantação das lagoas Sardinas por volta de 11.500 e El Angel em ca. 10.000 anos AP (Behling \& Hooghiemstra, 1998; 1999).

Nas áreas periféricas à distribuição dos cerrados, para a Turfa do Saquinho não há registro durante o UMG, porém na Serra dos Carajás, o predomínio de táxons de cerrado aberto com elementos da família Gramineae, indica o início de uma fase seca por volta de 23.000 anos AP. A presença de contatos abruptos e irregulares, com evidência de sedimentação mais arenosa e deposição de siderita, sugerem um hiato na sedimentação provavelmente devido à secagem do lago (Soubiès et al., 1991).

Nas áreas posicionadas nas maiores latitudes, próximas ao limite sul dos cerrados, na Lagoa de Serra Negra condições mais sazonais com duas estações estavam presentes especialmente em 20.000 anos AP. Há sugestão de um hiato na sedimentação e o início da fase seguinte por volta de 14.840 anos AP, com ausência de táxons de clima temperado e o aumento de elementos dos cerrados. $\mathrm{Na}$ Lagoa de Serra Negra embora não haja registro de condiçōes extremadas de seca há evidências de queda na temperatura (De Oliveira, 1992).

$\mathrm{Na}$ Serra do Salitre, há registro de um hiato na sedimentação entre $\mathbf{2 8 . 7 4 0}$ e ca. 17.000 anos AP, a partir de quando ocorre uma mudança na associação dos elementos. A floresta com domínio de Araucária da fase anterior ao hiato, é substituída por uma floresta semi-decídua, enquanto um pântano continua na depressão. Esta fase foi interpretada como um clima semelhante ao atual caracterizado por um padrão sazonal um pouco contrastado (Ledru et al., 1993).

Nas áreas mais orientais o registro de Lagoa dos Olhos se inicia durante o UMG por volta de 19.950 anos AP onde a vegetação era representada por um mosaico floresta-savana, de natureza bastante peculiar expressa na coexistência de árvores como Podocarpus, indicador de condições mais frias e Caryocar elemento típico dos cerrados, porém os palinomorfos predominantes pertencem às Gramineae. Este resfriamento abrange todo o UMG até 13.700 anos AP com 
referências à passagem das condições relativamente úmidas, para mais secas, a partir de 15.360 anos AP (De Oliveira, 1992).

Em Lagoa Santa os estudos geomorfológicos propõem um clima mais seco com temperaturas mais baixas, anterior a 13.000 anos AP, entretanto o registro palinológico só permitiu estabelecer a evolução da lagoa a partir de 6.200 anos AP, quando se dá a formação da mesma inicialmente de caráter intermitente (Parizzi, 1993).

$\mathrm{Na}$ área nuclear dos cerrados, o registro de Cromínia indica queda na umidade por volta de 18.500 anos $A P$, marcada pelo decréscimo acentuado nas concentrações dos táxons presentes, o desaparecimento total de Mauritia e a substituição do lago por um pântano. As condições de seca se acentuam em cerca de 10.000 anos AP, quando a concentração de palinomorfos decresce, o pólen arbóreo alcança os valores mínimos e o sedimento é representado por argila com fragmentos macroscópicos de plantas provavelmente pantanosas. Estas condições secas permanecem até ca. 7.700 anos AP, porém com temperaturas mais elevadas (Ferraz-Vicentini, 1993).

$\mathrm{Na}$ Chapada dos Veadeiros há registros de quatro incêndios de grande porte entre 18.054 e 17.970 anos AP, seguidos a partir de 17.960 anos AP de uma queda significativa na concentração de partículas de carvão e dos palinomorfos até se acentuar por volta de 15.840 anos AP, indicando retração na vegetação. $O$ registro da Lagoa Feia se restringe ao Holoceno (Ferraz-Vicentini, 1999).

O registro dos hiatos na sedimentação indicados para a Lagoa da Serra Negra e a Lagoa Campestre, a retração da vegetação arbórea em Crominia e na Chapada dos Veadeiros, além das mudanças das lagoas para condições pantanosas e a retração mais pronunciada da vegetação em Águas Emendadas e na Lagoa Bonita, promovendo a erosão do solo e deposição detrítica, indicam que a queda acentuada na precipitação e na temperatura, constituíram um fenômeno regional.

De modo geral, entre 22.000 e 18.000 anos AP a umidade e a temperatura começam a decrescer nos cerrados e atingem o máximo da secura entre $14.000 \mathrm{e}$ 10.500 anos AP. No entanto, o início da fase seca do UMG não é sincrônico nas diferentes áreas. Os registros indicam que há uma tendência ao retardamento do 
início desta fase nas maiores latitudes, fato este apontado por Salgado Labouriau (1997) que atribui este diacronismo à forma do continente, ao posicionamento das cadeias de montanhas e às diferenças de latitude dos sítios.

Desta forma, na região nuclear dos cerrados, o fato da fase seca ter tido início anteriormente, aliado à configuração geomorfológica das áreas da Lagoa Bonita e da Vereda de Águas Emendadas, que pela fraca declividade não favorecem a preservação da umidade ou a formação de microclimas, pode constituir uma explicação para a instalação das condições mais extremadas nas áreas citadas.

As diferenças entre a idade do início da fase seca em Águas Emendadas (ca. 21.000 anos AP) e na Lagoa Bonita (ca. 19.700 anos AP), áreas muito próximas, pode estar relacionada à erosão de parte do material depositado, já que em Águas Emendadas há um bem marcado contato erosivo seguido de deposição detrítica ao final desta fase. Portanto, parte do sedimento que corresponde à fase fria e úmida anterior ao UMG pode ter sido erodido.

$\mathrm{Na}$ Serra dos Carajás, posicionada em latitudes ainda mais iaixas e com uma configuração geomorfológica de um extenso platô, estas condições mais extremadas devem ter ocorrido também, uma vez que há registro de retração acentuada da vegetação ou eventual desaparecimento da mesma e exposição dos solos no periodo entre 23.000 e ca. 11.000 anos AP (Soubiès et al., 1991; Absy, 1996).

Da mesma forma, o retorno das condições úmidas não ocorre concomitantemente ao aumento da temperatura nem de forma sincrônica nas diferentes áreas. $O$ retorno da umidade se dá na Lagoa Bonita durante o Glacial tardio por volta de 13.000 anos AP, em condições diferentes das vigentes no Pleniglacial Superior, evidenciadas por uma modificação acentuada no conjunto polínico. A partir desta data passam a ocorrer entre os palinomorfos elementos típicos dos cerrados, inicialmente com predomínio de herbáceos e posteriormente com um aumento progressivo de elementos arbóreos como Brosimum, Byrsonima e Stryphnodendron.

Aparentemente, o retorno de condições mais úmidas se dá também de forma oscilatória, o que é evidenciado em ca. 7.900 anos AP (ecozona LB 5) pela presença de uma fase mais seca, ou com uma estação seca mais prolongada, 
responsável pelo rebaixamento do nivel do lago, a exposição e oxidação dos palinomorfos.

Condições efetivamente mais úmidas, com aumento de temperatura, são registradas à partir de 6.300 anos AP, evidenciado pelo registro de pólen de Mauritia que caracteriza a instalação da vereda. Em Águas Emendadas o retorno da vegetação, já com registro de Mauritia, e portanto da vereda, ocorre em torno de 7.200 anos AP.

Ainda na área nuclear dos cerrados, em Cromínia, os dados apontam para condiçōes ainda secas, porém não tão acentuadas e aumento de temperatura no intervalo entre 10.500 e 7.700 anos AP, onde a presença de uma turfa com restos macroscópicos de plantas e carvão indicam que a área foi queimada diversas vezes, sugerindo que a estação seca foi mais longa que atualmente. A partir de 6.680 anos AP a vereda retorna à área, indicando aumento na umidade e na temperatura e o conjunto palinológico reflete condições climáticas semelhantes às atuais (Ferraz-Vicentini, 1993).

Dados de geomorfologia da bacia do Córrego Taquara, também ıia região nuclear dos cerrados, próximo a área de estudo, indicam condições climáticas mais úmidas, a partir de 7.220 anos AP, após uma fase mais seca que a atual. A partir desta época há predomínio do intemperismo químico e ocorre o aprofundamento vertical do vale, com a instalação da floresta de galeria e o adensamento do cerrado. Os produtos originários desta fase de maior umidade são aluviōes com materiais orgânicos e coluviões remanejados de natureza argilosa (Mamede, 1999).

Dados de arqueologia da região de Serranópolis, no sudoeste do estado de Goiás, também indicam o aumento constante de umidade a partir de ca. 8.500 anos AP, quando ocorrem modificações na sedimentação dos abrigos, acompanhado pelo registro de uma nova tecnologia lítica representada pela Tradição Serranópolis. Esta mudança no tipo de artefatos esta relacionada às modificações na economia de subsistência, nas atividades desenvolvidas e nos restos alimentares.

A partir de 8.500 até ca. 6.500 anos AP, quando os abrigos são abandonados, ocorre uma diminuição acentuada na atividade de caça de pequenos mamíferos, substituída pela coleta de moluscos gastrópodes, com 
predomínio de indivíduos da familia Bulimulidae, que se desenvolvem nas paredes dos abrigos em locais úmidos e ricos em musgos (Schmitz et al., 1989).

De modo geral, na área nuclear dos cerrados, a partir de 7.000 a ca. 6.000 anos AP, com o aumento efetivo da umidade e da temperatura, pântanos se formam ou dão lugar a lagoas no Brasil Central. A vegetação era provavelmente semelhante à atual com diferentes gradações de cerrados, com manchas de cerrados densos ou florestas semi-decíduas, cortados por rios com matas de galeria ou veredas. O clima era provavelmente semelhante ao atual, semi-úmido e quente com 3 a 5 meses de estação seca dependendo do lugar (SalgadoLabouriau, 1997).

Nas áreas posicionadas nas menores longitudes, na Lagoa dos Olhos, a partir do Glacial tardio por volta de 13.700 anos AP, a umidade decresce e a temperatura aumenta, com a presença de um pântano e o registro de várias queimadas, indicando condições mais secas até ca. 6.790 anos AP, a partir de quando ocorre um aumento efetivo da umidade (De Oliveira, 1992).

Na região da Lagoa Santa, por volta de 6.200 anos AP, a lagoa não existia como tal, indicando um clima mais seco que o atual. A partir desta data, o registro de grandes deslizamentos que provocaram o represamento do córrego dando origem a lagoa, sugere um clima semi-árido com chuvas torrenciais e alta energia de corrente. Um aumento de umidade, por volta de 5.020 anos AP, é responsável por uma fase de lagoa intermitente, que se torna perene a partir de 4.600 anos AP (Parizzi, 1993; Parizzi et al., 1997).

No limite sul dos cerrados, na Lagoa de Serra Negra, a partir de 14.340 anos AP, a região passa a ser coberta por um mosaico de cerrado, floresta sazonal e uma larga floresta de galeria nas adjacências da lagoa e dos córregos, indicando condições mais úmidas, inicialmente frias e posteriormente quentes. Estas novas condições são inferidas pela ausência de táxons de clima temperado e o aumento dos elementos de cerrados e de floresta semi-decídua (De Oliveira, 1992).

$\mathrm{Na}$ Serra do Salitre, após o hiato na sedimentação, entre 28.000 e ca. 17.000 anos AP, a umidade aumenta gradativamente entre 16.000 e 11.000 anos AP e o início do Holoceno por volta de 9.500 anos AP é marcado por um padrão sazonal mais acentuado, porém com temperaturas mais altas (Ledru et al., 1996). 
O registro da Turfa do Saquinho, localizada atualmente em área de caatinga próxima ao limite oriental dos cerrados, se inicia por volta de 11.000 anos AP, com um conjunto caracterizado pela ausência de Mauritia. A presença de elementos típicos de floresta tropical úmida como Alchornea, llex, Palmae e Myrtaceae, além de alguns elementos arbóreos atualmente restritos à Floresta Amazônica e à Mata Atlântica, indicam alta biodiversidade e condições inexistentes atualmente na área, com expressivo aumento de umidade $e$ temperaturas baixas, quando do início da instalação da drenagem e da formação da turfa ao final do Pleistoceno.

A paisagem mantém-se dominada por elementos típicos de florestas tropicais até ca. 8.910 anos AP, a partir de quando se inicia um aumento progressivo da aridez que favorece o aumento de elementos de caatinga e dos cerrados. Entre ca. 6.790 anos AP há uma interrupção no registro palinológico até 6.230 anos AP, fato este interpretado como resultante de um clima ainda mais seco (De Oliveira et al., 1999).

Nas áreas ao norte, na Serra dos Carajás, entre 12.520 e 10.500 anos AP, a predominância de Gramineae com elementos dos cerrados indica que a floresta estava afastada do platô e possivelmente da área ao redor. $O$ aumento da umidade pode ser inferido com o desenvolvimento da floresta a partir de ca. 10.500 até 7.760 anos AP, seguido do registro de uma nova expansão de Gramineae e grande concentração de partículas de carvão, indicando condições de clima mais seco, provavelmente com estação seca mais prolongada por volta de 6.150 anos AP (Absy, 1996; Turcq et al., 1998).

Nos Llanos Orientais, após a fase mais seca e fria do UMG e do Glacial tardio, o retorno das condições mais úmidas ocorre no início do Holoceno, quando El Pinal se torna um lago por volta de 10.500 anos AP e há registro de aumento da área florestada. $O$ aumento da umidade é atestado também pela formação da Lagoa Sardinas em ca. 11.500 anos AP e Angel em 10.000 anos AP, acentuandose por volta de 8.000 anos AP, quando se inicia o registro da lagoa Carimagua. $O$ registro polínico das lagoas indica que, de modo geral, a proporção entre as áreas das savanas e das florestas de galeria se manteve mais ou menos constante após 11.000 anos AP (Behling \& Hooghiemstra, 1998; 1999). 
O Lago de Valência, hoje com ca. $40 \mathrm{~m}$ de profundidade, estava seco no período anterior a 13.000 anos AP. Um pântano ou lagoa intermitente passa a ocupar a parte atualmente mais funda do lago entre 12.900 e 10.500 anos AP (Salgado-Labouriau, 1980). A partir desta data forma-se um lago salobro, evidenciado pela presença de diatomáceas e ostracodes característicos destas condiçōes, indicando um clima quente e seco com mais evapotranspiraçăo que precipitação (Bradbury et al., 1981).

A fase mais úmida do lago ocorre entre 7.130 e 5.480 anos AP, quando o lago, hoje endorreico, transbordou, ocorrendo também a expansão das florestas nas montanhas e nas encostas ao redor do lago. A vegetação que ao final do Pleistoceno era característica de condições semi-áridas passa a ser representada a partir de ca. 7.000 anos AP por uma savana semelhante aos cerrados brasileiros, porém mais pobre em espécies (Salgado-Labouriau, 1980).

De modo geral, os dados das terra baixas tropicais mostram variaçōes nas condições vigentes durante o UMG, o Glacial tardio e o início do Holoceno, para o conjunto das áreas analisadas.

$\mathrm{Na}$ área nuclear dos cerrados, e em direção às latitudes menores, na Serra dos Carajás, nos Llanos Orientais e no Lago de Valência, após a fase de condições frias e secas do UMG, há uma tendência de aumento da umidade de forma oscilatória, a partir do Glacial tardio e início do Holoceno, provavelmente com a presença de estações secas mais prolongadas nas fases menos úmidas.

Condições úmidas mais constantes e temperaturas mais altas são evidenciadas, na área nuclear dos cerrados, pela implantação ou retorno das veredas entre ca. 7.200 e 6.300 anos AP. O aumento de temperatura a partir do início do Glacial tardio é atestado na Lagoa Bonita com a mudança do conjunto dos palinomorfos que caracteriza a ecozona LB 4, marcada pela ausência de elementos indicadores de clima frio e o início da dominância dos táxons dos cerrados. No Lago de Valência o aumento da temperatura é atestado pelo aumento da evapotranspiração, originando o lago salobro a partir do início do Holoceno.

Nas áreas posicionadas nas mais altas latitudes, próximas ao limite sul dos cerrados, representadas pela Lagoa de Serra Negra e a Lagoa Campestre na Serra do Salitre e a área periférica oriental representada pela Turfa do Saquinho, 
os registros durante o Glacial tardio e o início do Holoceno mostram-se divergentes da área nuclear dos cerrados.

Nestas áreas, para este período, há indicações, embora não sincrônicas, de condições úmidas e frias com oscilaçōes para fases mais secas ou clima mais sazonal por volta de 9.500 anos AP na Serra do Salitre, e um máximo de aridez por volta de 6.790 anos AP na Turfa do Saquinho. As variaçōes paleoclimáticas do Glacial tardio e início do Holoceno foram associadas por Martin et al. (1997) à mudanças na localização da Zona de Convergência Intertropical (ZCIT) para latitudes mais baixas, provocando aumento de precipitação nas maiores latitudes.

Aparentemente, o aumento gradativo da umidade durante o Holoceno nas diversas áreas, mesmo que não tenha ocorrido de forma sincrônica, culminou com uma fase de condições de umidade maior que as atuais, evidenciada pela expansão das veredas, das matas de galeria e do cerrados arbóreos.

$\mathrm{Na}$ área nuclear dos cerrados, este aumento da umidade é registrado em Águas Emendadas, por volta de 2.500 anos AP, com os valores máximos de Mauritia e mínimos de partículas de carvão e na Lagoa Bonita, em ca. 2.100 anos AP, com a expansão dos táxons arbóreos do cerrado e de Mauritia.

Nas demais áreas de cerrados também há registros do aumento de umidade que ocorre na Lagoa Feia entre 4.850 e ca. 3.000 anos AP. Na Lagoa Santa, entre 3.000 e ca. 1.400 anos AP, ocorre uma expansão dos elementos de cerrados e de mata úmida, e na Lagoa dos Olhos as condições foram mais úmidas entre 4.000 e ca. 1.500 anos $\mathrm{AP}$, com a instalação de condições semelhantes às atuais por volta de 1.320 anos AP (Parizzi, 1993; De Oliveira, 1992).

As oscilaçōes na precipitação, marcando episódios de curta duração de clima seco, também são registrados no decorrer do Holoceno. Na Lagoa Bonita, os valores máximos de partículas de carvão associados à queda nos valores de pólen de Mauritia, registrados em ca. 5.300 anos AP (idade interpolada), atestam estas condições. Na Serra do Salitre uma fase seca está presente entre 5.500 e 4.500 anos AP, evidenciada pelo registro de uma sedimentação detrítica, com retração da vegetação arbórea. O retorno efetivo da umidade se dá entre 4.000 e 3.000 anos AP e o recobrimento da área pela floresta mesofítica semi-decídua por volta de 3.000 anos AP (Bertaux et al., 1996). 
Nas áreas periféricas, na Serra dos Carajás, no período_entre ca. 7.000 e 4.600 anos AP há identificação de eventos de incêndios concomitantes com episódios curtos de clima seco com freqüência variada. Durante esta fase, em que a presença de elementos de floresta úmida indicavam condições de maior precipitação, após a fase seca do UMG, as queimadas frequentes constituiam limitações ao pleno desenvolvimento da floresta (Turcq et al., 1998).

$O$ início da fase úmida, por volta de 4.600 anos $A P$, ainda com registro de breves períodos secos, mostra que o retorno efetivo da umidade nas terras baixas tropicais acompanhou a tendência verificada, quando do início da fase seca do UMG, de retardamento da resposta às mudanças climáticas nas menores latitudes.

$\mathrm{Na}$ Turfa do Saquinho, entre ca. 6.000 e 2.900 anos AP são registradas várias oscilações na umidade com alta concentração de Mauritia por volta de 4.900 anos AP indicando o retorno da umidade. A partir de ca. 4.200 anos AP torna-se clara a tendência à expansão dos elementos de caatinga e cerrado, que vêm até o presente, indicando um aumento de aridez que distoa do padrão de tendência ao aumento da umidade na região nuclear dos cerrados.

Estas oscilações climáticas dos últimos 7.000 anos AP, registradas nas áreas da Serra dos Carajás, na Serra do Salitre e na Turfa do Saquinho, bem como em áreas do sudeste, tem sido associadas por diversos autores, à existência de condições tipo EL Niño com duração de centenas e dezenas de anos (Martin et al., 1993; 1995; Suguio et al., 1993; De Oliveira et al., 1999).

O caráter continental das modificações climáticas e das oscilações na precipitação durante o Holoceno é evidenciado também, por dados de outras áreas. Após ca. 7.000 anos AP há registros de interrupção na sedimentação seguidos de episódios erosionais por volta de 6.000 a 7.000 anos AP no Córrego Lageado em Goiás e em Poços de Caldas entre 4.000 e 5.000 anos AP, sugerindo a ocorrência de diversas flutuações com condições mais secas de curta duração, dentro de um paleoclima globalmente úmido (Suguio et al., 1993).

Oscilações indicando aumento de umidade são registrados também nestas áreas e em outras localidades da região sudeste por volta de 5.500 e ca. 5.000 anos AP. Este aumento de umidade é evidenciado no Córrego Lageado, em Goiás e em Poços de Caldas, pela presença de troncos de árvores sobre um 
conglomerado basal. Nos depósitos aluviais do Rio Tamanduá, no estado de São Paulo, a formação de turfas sobre superfícies erosivas atesta o aumento da umidade também na região sudeste (Suguio et al., 1993).

A amplitude das variações paleoclimáticas do Holoceno pode ser observada a partir dos estudos sobre flutuações do nível do mar na costa brasileira. A análise das formações costeiras indica que o nível do mar foi mais alto que o presente, atingindo um máximo por volta de 5.100 anos AP. A emergência da costa brasileira após 5.100 anos AP foi interrompida por duas importantes flutuações com amplitude de 2 a $3 \mathrm{~m}$ e duração de 200 a 300 anos, caracterizando novamente as oscilaçōes (Martin \& Suguio, 1992; Martin et al., 1986).

As oscilações na precipitação no decorrer do Holoceno são registradas também para a região Andina e dos Llanos. Nos Llanos Orientais da Colômbia uma fraca oscilação, por volta de 3.850 anos AP, com aumento de umidade, é evidenciada por abundância de pólen de Mauritia, Mauritiella e Alchornea. O registro nesta fase de Cecropia, elemento colonizador de áreas devastadas, sugere também o início da intervenção humana efetiva na região (Behling \& Hooghiemstra, 1998; 1999). Nos Andes tropicais, há registros de uma fase mais úmida e quente entre 3.000 e 2.500 anos AP quando a faixa altitudinal de vegetação se situava acima da posição atual (van der Hammen, 1991)

De modo geral, os registros da Lagoa Bonita e de Águas Emendadas, coincidem com pequenas variações com relação às datas e amplitudes dos fenômenos, com os demais sítios da área nuclear dos cerrados. Estas áreas mostram um padrão geral com condições mais frias e úmidas que as atuais, durante o início do Pleniglacial Superior até ca. de 21.000 a 19.000 anos AP, seguidas pela instalação de condiçōes mais secas e frias durante o UMG. O retorno da umidade se dá a partir do Glacial tardio de forma oscilatória, com condiçōes efetivas de maior umidade e aumento de temperatura por volta de 8.000 a ca. 7.000 anos AP, o que favorece o retorno ou a instalação das veredas entre 7.000 e 6.000 anos AP.

Nas áreas periféricas localizadas mais ao sul em latitudes maiores, ou na área mais oriental, representada pela Turfa do Saquinho, os registros quando ocorrem, mostram condiçōes diversas das observadas na área nuclear dos 
cerrados durante o UMG, o Glacial tardio e o início do Holoceno._Nestas áreas, os registros deste período apontam para condições frias e úmidas, com oscilações que foram associadas às incursões da Frente Polar fria e úmida durante o tempo glacial e o início do Holoceno (Ledru et al., 1996; De Oliveira, et al., 1999). Entretanto, esta proposta não corresponde aos registros da área nuclear dos cerrados ou posicionadas em latitudes menores.

Considerando os últimos 7.000 anos AP, a partir da instalação efetiva de condições gerais de aumento na precipitação e na temperatura, principalmente após o UMG e o Glacial tardio, o fato marcante para todas as áreas é a presença de episódios, não sincrônicos, freqüentemente de curta duração, de oscilações na umidade, tanto com queda, quanto com aumento da precipitação. A pequena amplitude e o diacronismo destas oscilações dificulta o estabelecimento de uma causa única para as mudanças climáticas, principalmente se considerada a dimensão continental das áreas analisadas.

As dificuldades nas correlações entre as oscilações climáticas durante a parte superior do Holoceno, principalmente a partir dos últimos 5.000 anos AP estão relacionadas também à precisão dos métodos utilizados nas análises paleoecológicas. Além das margens de erros nas datações radiocarbônicas, a análise palinológica não apresenta precisão suficiente para registrar as oscilações de pequena amplitude, como aparentemente são as oscilações registradas durante o Holoceno.

Quanto à estas variações observadas nas diferentes áreas é preciso ressaltar também, que o final do último glacial provocou um aumento acentuado do nivel do mar, diminuindo o caráter de continentalidade das áreas interiores nas terras baixas tropicais e consequentemente as condições climáticas extremadas.

Este fato pode ter favorecido a instalação de condições climáticas oscilatórias de caráter mais localizados, onde a ação dos parâmetros físicos e biológicos de cada área teriam um peso mais pronunciado. $\mathrm{O}$ condicionamento local poderia então explicar as variações nas amplitudes dos fenômenos e nas idades, registradas principalmente no Holoceno a partir de ca. 8.000 anos AP.

Quanto à composição da vegetação, a diversidade e as modificações no conjunto, observados principalmente durante o Pleniglacial Superior, parecem 
estar relacionadas ao comportamento individual de cada táxon e à configuração da rede de drenagem das terras baixas tropicais.

Quedas na temperatura devem ter facilitado a entrada de táxons caraterísticos de clima frio, enquanto o aumento da precipitação favorecia a expansão das florestas de galerias, criando uma rede através da qual os elementos poderiam migrar de um bioma para outro, resultando em uma diversidade e um conjunto de vegetação sem similar atual (Oliveira-Filho \& Ratter, 1995). Esta situação é evidenciada no conjunto polínico da Lagoa Bonita em ca. 22.300 anos AP durante o máximo da fase úmida e fria do Pleniglacial Superior.

Neste sentido, o aumento da temperatura durante o Holoceno resultou na expulsão dos elementos de clima frio para maiores latitudes ou quando possivel para áreas de maiores altitudes, o que é observado na área de estudo pela presença de Podocarpus nas localidades mais elevadas das chapadas do Distrito Federal. $O$ aumento da temperatura parece estar relacionado também à expansão dos táxons característicos do Cerrado, durante o Holoceno e principalmente à presença de Mauritia que caracteriza as veredas, atualmente restritas às áreas com invernos amenos, livres de geadas.

De modo geral, para todas as áreas analisadas, a instalação de condições semelhantes às atuais, responsáveis pelo padrão de distribuição da vegetação atual, ocorre efetivamente em torno de 2.000 anos AP. Este fato mostra também a rapidez com que a vegetação responde às mudanças climáticas $e$ conseqüentemente à interferência antrópica.

Embora os fenômenos possam se constituir em aspectos globais, não são sincrônicos e pode-se constatar que as diferenças na resposta de cada área às modificações paleoclimáticas, não só com relação às idades, como em relação às modificações na paisagem, são influenciadas também pelas características locais.

A interação entre os diferentes parâmetros físicos, onde se incluem a latitude, a altitude, o condicionamento geológico, a compartimentação geomorfológica local e regional, o tipo de solo, o clima regional e as variações de clima local, além dos parâmetros biológicos, representados principalmente pela cobertura vegetal e mais recentemente pela ação humana, são fundamentais para estabelecer a resposta de cada área às modificações paleoclimáticas. Esta influência dos parâmetros locais parece se acentuar principalmente quando as 
condições climáticas globais não são tão extremadas quanto aquelas que ocorrem durante os estádios glaciais.

Desta forma, o mosaico atual das áreas de cerrados, com a diversidade de fitofisionomias presentes, deve constituir uma resposta à interação entre estes parâmetros físicos e biológicos locais, com as modificações geológicas e climáticas de caráter global e eventualmente regional que afetaram o Continente Sul Americano principalmente a partir do Neógeno e durante o Pleistoceno.

\subsection{Dados Arqueológicos}

As discussões sobre os cerrados não costumam levar em consideração as mudanças na vegetação no decorrer do tempo geológico. Aliado a este fato, a complexidade das interações na distribuição das diferentes fitofisionomias, dificulta ainda mais uma análise criteriosa sobres as teorias relativas à origem deste bioma.

Neste sentido, os dados paleoecológicos e principalmente a caracterização das modificações no conjunto da vegetação através da análise palinológica podem contribuir na compreensão de algumas questões e levantar considerações visando uma discussão cada vez mais ampla, embora não definitiva.

A maior limitação na utilização dos dados palinológicos prende-se ao pequeno número de sítios analisados na área nuclear dos cerrados e principalmente ao fato de que os registros não atingem, com datas absolutas, períodos anteriores à 35.000 anos AP. Isto inviabiliza estudos sobre a origem e a elaboração de generalizações e de modelos de amplitude regional, principalmente para toda a área de ocorrência deste bioma.

Entretanto, com os dados de caráter paleoecológicos e arqueológicos existentes para a área nuclear dos cerrados, é possivel levantar mais algumas consideraçōes sobre a questão da origem antrópica dos cerrados, cuja primeira referência segundo Warming (1908) foi do pesquisador dinamarquês Peter Lund.

Ao observar os cerrados da região de Lagoa Santa, Lund concluiu que se os mesmos não fossem queimados, como eram pela ação humana, se transformariam em matas no decorrer do tempo (Warming, 1908). Esta proposta já foi bastante questionada, inclusive por Warming (1908) que a considerava 
inadmissivel, restando somente uma última análise a fazer, a_partir dos dados palinológicos e arqueológicos.

A proposta de uma origem antrópica para os cerrados, está relacionada à ação do fogo na vegetação, o qual seria induzido de forma artificial pelas populações pré-históricas. O primeiro aspecto a considerar é a efetiva atuação de um regime de fogo sobre a vegetação dos cerrados.

Segundo Andreae (1991, apud Ferraz-Vicentini, 1999), a partir do momento em que as plantas se tornaram abundantes o suficiente para acumular combustível para a propagação do fogo, juntamente com condições climáticas adequadas (duração e intensidade das estações secas) e havendo fonte de ignição (relâmpagos), regimes naturais de fogo podem ter se estabelecido dentro de determinados periodos.

A ocorrência de fogo nos ecossistemas pode estar relacionada aos distúrbios de curta duração, como por exemplo duração das estações secas e freqüência da ocorrência de relâmpagos, ou de longa duração como as flutuações climáticas (Goldammer, 1991 apud Ferraz-Vicentini, 1999).).

Durante o Pleistoceno, a alternância de estádios glaciais com interglaciais, resultantes da interação de diversos fenômenos astronômicos, geofísicos e geológicos, provocaram modificações significativas no Hemisfério Sul (Suguio, 1999). Como as famílias botânicas presentes nos biomas do Continente Sul Americano já estavam estabelecidas nesta época, estas modificações paleoambientais que afetaram a composição e distribuição da vegetação devem ter afetado também, direta ou indiretamente, o regime de fogo.

Segundo Dias (1999, apud Ferraz-Vicentini, 1999), mudanças no regime de fogo podem ser causadas por alterações na freqüência e na intensidade do fogo, que podem por sua vez, resultarem de alterações climáticas e da ação do homem, interagindo com as caracteristicas de cada ecossistema.

O fogo, juntamente com a sazonalidade das chuvas, o conteúdo nutricional e as propriedades físicas dos solos, têm sido apontados como os fatores determinantes para a vegetação dos cerrados, onde a principal fonte natural de ignição, para o início das queimadas, são as descargas elétricas que ocorrem naturalmente na região dos cerrados, principalmente no período entre agosto e 
setembro quando as condições de seca estão mais acentuadas_(Coutinho, 1990; Dias, 1992).

Estudos experimentais desenvolvidos por Coutinho (1990) para verificar o impacto do fogo no cerrado mostraram que este elemento faz parte do processo dinâmico de crescimento, morte e sucessão da comunidade vegetal, ou seja, faz parte da dinâmica do ecossistema como componente integrado que contribui para a manutenção desta comunidade.

Muitos dos componentes florísticos do cerrado apresentam características adaptativas que evidenciam este dinamismo, como a forte suberização de troncos e galhos das árvores funcionando como isolante térmico, além de aspectos da biologia reprodutiva como a presença de plantas com alta capacidade de rebrota e dispersão de sementes logo após o fogo (Cesar, 1980; Coutinho, 1990; Dias, 1999 apud Ferraz-Vicentini, 1999).

Além destas características morfológicas individuais de alguns elementos botânicos, a ação do fogo nos cerrados foi apontada também como influenciando de forma direta ou indireta na distribuição das espécies e na diversidade da comunidade vegetal (Cesar, 1980; Coutinho, 1990). A relação do fogo com o padrão agregado das espécies arbóreas em áreas de Cerrado no sentido restrito é também sugerido por Álvares da Silva (1995) em um estudo sobre a ecologia evolutiva do Parque Nacional das Emas na área nuclear dos cerrados.

Desta forma, fica clara a presença do elemento fogo como mais um dos fatores que interagem na vegetação dos cerrados, restando verificar se a origem foi antrópica ou natural durante o Quaternário tardio.

A ocorrência de fogo é registrada nos sedimentos de testemunhos de sondagem, a partir da presença de partículas de carvão. Os dados palinológicos mostram que a presença de queimadas nas áreas de cerrados está evidenciada em diversos locais estudados durante o final do Pleniglacial Médio e o Pleniglacial Superior.

Os registros da presença de partículas de carvão em abundâncias expressivas, neste período, são verificadas na área de estudo, a Lagoa Bonita, em Cromínia (Ferraz-Vicentini, 1993), em Águas Emendadas (Barberi, 1994), na Lagoa dos Olhos (De Oliveira, 1992), na Chapada dos Veadeiros (FerrazVicentini, 1999) e na Serra dos Carajás (Absy et al., 1991). 
Entretanto, os dados arqueológicos indicam a presença efetiva e comprovada de populações pré-históricas em áreas de cerrados, somente a partir de 11.000 anos AP, em poucas localidades como Serranópolis (Schmitz et al., 1989; Schmitz, 1994) e no Vale do Peruaçú (Prous, 1991), se expandindo para outras áreas a partir de 10.000 anos AP. A origem destes primeiros grupos préhistóricos do Planalto Central está relacionada às ocupações anteriores, localizadas nas áreas de formações abertas existentes no norte da América do Sul (Barbosa, no prelo).

As populações que se instalaram efetivamente à partir de 10.000 Anos AP em áreas de cerrados, que constituem a Tradição Itaparica, possuiam uma cultura material já voltada para a exploração de áreas abertas, com uma economia de subsistência baseada na caça de pequenos animais e a coleta generalizada. Os instrumentos líticos destes grupos servem às funções relacionadas à estas atividades (Schmitz, 1994; Barbosa \& Schmitz, 1998).

Durante o Holoceno, a presença de partículas de carvão nos sedimentos também é evidente e abundante na Serra dos Carajás, em Águas Emendadas, em Cromínia, na Lagoa Feia e na Chapada dos Veadeiros. Para este período, com relação à influência da atuação do homem pré-histórico através de queimadas induzidas, é importante ressaltar que, estas comunidades que ocuparam as áreas de cerrados no periodo entre 11.000 e ca 6.500 anos AP, eram essencialmente núcleos familiares, de poucos indivíduos que formavam grupos nômades de caçadores e coletores.

Estes grupos, circulavam por uma área extensa onde a utilização do fogo constituía uma das técnicas de caçadas, utilizada em determinadas épocas do ano (Schmitz, 1994; Barbosa \& Schmitz, 1998). Por outro lado, outras áreas com evidências de ocupação humana mais permanente como a Lagoa Santa (Prous, 1991), aparentemente não apresentam registro marcado de partículas de carvão.

Para esta fase do Holoceno é necessário ressaltar também que a atividade de caça foi mais intensa, nas áreas de cerrados, no periodo entre 11.000 e ca. 9.000 a 8.500 anos AP, constituindo uma atividade básica da Tradição Itaparica.

Entre 8.500 e 6.500 anos AP, a partir de quando os abrigos foram desocupados e se inicia uma fase de registros escassos, os vestígios arqueológicos da Tradição Serranópolis indicam que a atividade de caça foi em 
grande parte substituída pela coleta de moluscos, abundantes nos abrigos neste intervalo de tempo (Schmitz, 1994; Barbosa \& Schmitz, 1998).

A relação entre um aumento de partículas de carvão e uma indução antrópica do fogo, pode ser sugerida ao menos em alguns níveis posicionados no Holoceno mais recente, principalmente quando este aumento das partículas de carvão não está relacionado aos períodos mais secos, onde as queimadas seriam mais constantes. Entretanto, é preciso considerar também a precisão das análises palinológicas onde cada nível analisado pode representar um intervalo de tempo de até centenas de anos, dependendo da taxa de sedimentação local, e o fato de que as comunidades pré-históricas da região dos cerrados, eram pequenas e essencialmente nômades até ca. 6.500 anos AP.

$\mathrm{Na}$ Lagoa Bonita os maiores valores de partículas de carvão (Figura 4.15) correspondem à idade interpolada de ca. 5.300 anos AP, e não podem ser associados à intensificação da ação humana devido ao desenvolvimento da agricultura: As primeiras comunidades ceramistas e agricultoras, que tinham uma atuaçăo mais efetiva sobre o meio, eventualmente com a utilização de queimadas para a preparação das áreas de cultivos, constituiam ocupaçōes incipientes que ainda ocupavam abrigos e que surgiram nas áreas de cerrados à partir de ca. 2.400 anos AP (Silva 1995).

Os grupos com uma agricultura mais efetiva, com grandes aldeias populosas, são representados pelas tradições Aratu e Uru, cujas idades mais antigas nas áreas do Planalto Central são de ca 1.100 e 900 anos AP respectivamente. Cabe ressaltar também, que a tradição Uru que apresentava uma distribuição mais ocidental, ocupava preferencialmente as áreas férteis das várzeas dos grandes rios e que as aldeias da Tradição Aratu de distribuição mais oriental, estavam normalmente localizadas sobre terrenos próximos às áreas com solos de maior fertilidade, normalmente ocupados por cerrados densos ou matas de interflúvios (Silva, 1995).

Os dados paleoecológicos apontam para uma ação mais efetiva do homem, provocando aumento na freqüência de queimadas ou maior intensidade do fogo, principalmente a partir dos tempos coloniais, como é constatado pelo aumento na concentração de partículas de carvão no estudo da história do fogo realizado sobre os sedimentos da Lagoa Feia (Ferraz-Vicentini, 1999). 
Finalizando, a ação do fogo somente, não explica também as mudanças repentinas de vegetação que se observam nos cerrados, em áreas próximas. As queimadas freqüentes indubitavelmente modificam a flora $e$ as características fisionômicas dos cerrados, porém não constituem o parâmetro responsável pelos processos evolutivos que deram origem ao aparecimento das plantas típicas deste ecossistema e principalmente, não podem ser associadas às ocupações pré-históricas dos cerrados. 


\section{CONCLUSÕES}

As seguintes conclusões podem ser obtidas a partir das análises paleoecológicas dos sedimentos da Lagoa Bonita, localizada no Planalto Central Brasileiro, em área atualmente recoberta pelos cerrados:

1. Os dados palinológicos fornecem evidências de diversas alterações climáticas, que modificaram o conjunto e a distribuição da vegetação a partir de ca. 26.000 anos AP (idade extrapolada), quando se inicia a formação da Lagoa Bonita, até o presente.

2. Na fase anterior à instalação da lagoa, os dados da análise mineralógica indicam processos de intemperismo por laterização que resultaram na formação de um solo espesso, constituído predominantemente por caolinita e óxidos e hidróxidos de ferro e alumínio, resultantes da alteração de metassedimentos do Grupo Paranoá.

3. A instalação da Lagoa Bonita em ca. 26.000 anos AP indica condições mais úmidas que a fase anterior, possibilitando o registro da uma seqüência sedimentar com a preservação de palinomorfos que permitiram estabelecer sete ecozonas em função das diferenças na ocorrência e na proporção dos elementos botânicos identificados.

4. O período entre ca. 26.000 e 19.700 anos AP (idades extrapoladas), que corresponde às ecozonas LB 1, LB 2 e LB 3, é marcado por condições gerais de clima mais frio e úmido que $O$ atual, evidenciadas pela ocorrência em proporçōes expressivas de elementos como llex, Hedyosmum e Podocarpus.

5. Este período, situado no Pleniglacial Superior, apresenta oscilações na precipitação evidenciadas pelas modificações nas proporções relativas dos elementos botânicos presentes nas três ecozonas deste intervalo. 
6. Ocorre também uma tendência ao aumento da precipitação e queda na temperatura a partir do início desta fase, cujo máximo é registrado em ca. 22.900 anos AP com a expansão de todos os táxons presentes. A partir desta idade há uma tendência de quedas na umidade e temperatura, culminando em ca. 19.000 anos AP (idade extrapolada) com a instalação de condições diferenciadas das vigentes no Pleniglacial Superior .

7. O Último Máximo Glacial entre ca. 19.000 e ca. 13.000 anos AP é marcado por condiçōes provavelmente semi-áridas, com baixas temperaturas, responsáveis pela retração da vegetação e instalação de processos erosivos, chegando a expor sub-aereamente os metassedimentos do Grupo Paranoá.

8. O retorno da umidade e da vegetação ocorre no Glacial tardio em ca. 13.000 anos AP (idade extrapolada), em condições de clima ainda frio, porém mais ameno. A vegetação, diferente da existente durante o Pleniglacial Superior, é representada iricialmente por elementos botânicos pioneiros e por elementos característicos do bioma Cerrado. As variações, principalmente na proporção dos elementos, a partir do Glacial tardio rumo ao presente, possibilitaram o estabelecimento de quatro ecozonas para este intervalo, representadas pela ecozonas LB 4, LB 5, LB 6 e LB 7.

9. O retorno da umidade durante o início do Holoceno se dá de forma oscilatória, com a intercalação de fases mais secas dentro de um período com condições genericamente mais úmidas que a fase anterior, ou com a presença de estaçōes secas mais prolongadas. Este fato é evidenciado na Lagoa Bonita, na ecozona LB 5 em ca. 7.900 anos AP, onde o rebaixamento do nivel do lago provocou a oxidação e destruição parcial dos palinomorfos.

10.0 retorno da umidade acompanhado de aumento efetivo da temperatura, representado pelas duas ecozonas superiores, ocorre em ca. 7.000 anos AP, com a instalação das veredas no Planalto Central, evidenciada pela presença de Mauritia, cujo primeiro registro na Lagoa Bonita se dá em torno de 6.300 anos AP. 
11. Após o aumento efetivo da temperatura no Holoceno, há evidências de oscilações na precipitação tanto com registro de fases mais secas ou com estações secas mais prolongadas, como fases de maior umidade quando se dá a expansão das veredas e das matas. Condições semelhantes às atuais são registradas principalmente à partir de ca. 2.000 anos AP nas terras baixas tropicais.

12. As modificações climáticas evidenciadas na Lagoa Bonita durante o Pleniglacial Superior, o Último Máximo Glacial e o Glacial tardio estão em concordância com os dados obtidos em outros sítios localizados na área nuclear dos cerrados e nas baixas latitudes. Coincidem também, com as alterações registradas nos Llanos Orientais, no Lago de Valência e nos Andes tropicais, evidenciando o caráter continental das modificações e suas relações com as alterações climáticas da glaciação Würm (Wisconsin).

13. As modificações climáticas evidenciadas na Lagoa Bonita durante o Pleniglacial Superior e o Último Máximo Glacial, coincidem também com os dados obtidos para os sítios posicionados no limite sul da área de ocorrência dos cerrados, porém diferem para o período do Glacial tardio e início do Holoceno, o que é verificado também com relação à Turfa do Saquinho, localizada próximo ao contato entre o cerrado e a caatinga.

14. Oscilações na precipitação são registradas durante o Holoceno para o conjunto das áreas analisadas e para outras localidades, porém freqüentemente os registros não são sincrônicos nem apresentam a mesma amplitude o que sugere a ação de condicionantes locais.

15. Durante a fase fria e úmida do Pleniglacial Superior as comunidades vegetais da região apresentavam um conjunto com alta biodiversidade, diferente do que é registrado atualmente para quaisquer das fitofisionomias dos cerrados.

16.A presença de Mauritia nos sedimentos somente a partir de 7.000 anos AP e a sua distribuição moderna em áreas com invernos suaves, sem ocorrência de 
geadas, sugere a utilização deste elemento como indicador de aumento da temperatura após a fase fria e seca do UMG.

17. Há registros de incêndios em áreas de cerrados em períodos anteriores a ocupação humana. A partir do Holoceno as evidências de queimadas não estão necessariamente associadas a ação antrópica, que se torna mais efetiva em áreas de cerrados a partir dos tempos coloniais.

18. As variações na resposta da vegetação às mudanças climáticas, observadas nas áreas analisadas, aparentemente são devidas também aos diferentes parâmetros físicos e biológicos de cada área. Estes condicionantes poderiam explicar as variações na intensidade e na duração dos eventos e teriam uma importância menor em épocas de climas extremados, como os que ocorreram durante alguns intervalos dos estádios glaciais. 


\section{REFERÊNCIAS BIBLIOGRÁFICAS}

AB' SABER,A.N. (1977) Espaços ocupados pela expansão dos climas secos na América do Sul, por ocasião dos periodos glaciais quaternários. USP, Inst. Geogr., Paleoclimas, 3:1-19.

ABSY,M.L. (1996) A vegetação e o clima da Amazônia durante o Quaternário. In: PAVAN,C. Uma estratégia latino-americana para a Amazônia. São Paulo, Fundação Memorial da América Latina, Editora da UNESP, p. 149-157.

ABSY,M.L.; CLEEF,A.M.; FOURNIER,M.; MARTIN,L.; SERVANT,M.; SIFEDDINE,A.; FERREIRA DA SILVA,M.F.; SOUBIES,F.; SUGUIO,K.; TURCQ,B.; VAN DER HAMMEN,T. (1991) Mise en evidence de quatre phases d'overture de la forêt dense dans le sud-est de l'Amazonie au cours des 60,000 dernières années. Première comparaison avec d'autres régions tropicales C. R. Acad. Sci., Paris, Ser. II, 312:673-678.

ADÁMOLI,J. (1981) O pantanal e suas relações fitogeográficas com os cerrados. In: CONGRESSO NACIONAL DE BOTÂNICA 22, Anais. Teresina, SBB/ Universidade Federal do Piauí, p. 109-119.

ADÁMOLI,J.; MACEDO,J.; AZEVEDO,L.G.; MADEIRA NETO,J. (1987) Caracterização da região dos cerrados. In: GOEDERT,W.J. Solos dos cerrados: tecnologias e estratégias de manejo. São Paulo, Nobel/EMBRAPA, p. 33-74.

ALEXANDRE,A.; MEUNIER,J.D.; MARIOTTI,A.; SOUBIES,F. (1999) Late Holocene phytolith and carbon-isotope record from a latosol at Salitre, South-Central Brazil. Quaternary Research, 51:187-194.

ALMEIDA,F.F.M. (1967) Origem e evolução da Plataforma Brasileira. Boletim Divisão Geol. Mineral. DNPM, Rio de Janeiro, n. 241, 36 p.

ALMEIDA,F.F.M. (1977) O Cráton do São Francisco. Revista Brasileira de Geociências, São Paulo, 7: 349-364.

ALMEIDA,F.F.M. \& HASUI,Y. (1984) O Pré-Cambriano do Brasil. São Paulo: Edgard Blücher, $376 \mathrm{p}$.

ALMEIDA,F.F.M.; HASUI,Y.; NEVES,B.B.B.; FUCK,R. (1977) Províncias estruturais brasileiras. In: SIMPÓSIO DE GEOLOGIA DO NORDESTE, 8 , Campina Grande, Atas, Campina Grande: SBG p. 363-391.

ÁlVARES DA SILVA,O. (1996) Ecologia evolutiva de um cerrado do Parque Nacional das Emas, Goiás. Goiânia, 134 p. Dissertação de Mestrado Instituto de Ciências Biológicas, Universidade Federal de Goiás. 
ALVES,D.B. (1987) Desenvolvimento da metodologia de preparação de amostras para análise difratométrica de argilominerais no Centro de Pesquisas da Petrobrás. Bol. Geoc. PETROBRÁS, 1(2):157-175.

ALVIM,P.T. (1996) Repensando a teoria da formação dos campos cerrados. In: VII SIMPÓSIO SOBRE O CERRADO. I INTERNATIONAL SYMPOSIUM ON TROPICAL SAVANNAS, Brasília. Anais, Brasilia, p. 56-58.

ALVIM,P.T. \& ARAUJO,W.A. (1952) El suelo como factor ecológico em el desarrolo de la vegetación em el planalto central de Brasil. Turrialba, 2:153160.

ANDERSEN,S.T. (1960) Silicone oil as a mounting medium for pollen grains. Danm. Geol. Unders. IV Series, 4(1):24 p.

ANDERSON,P.; ANDREWS,J.; BRADLEY,R.; BRUBAKER,L.; EDWARDS,M. (1993) Paleoclimates of arctic lakes and estuaries. PAGES Workshop Report, Series 94(1):1-53.

ARAGÃO,L.T. (1994) Ocupação Humana de Brasilia. In: NOVAIS PINTO,M. Cerrado: Ocupação, caracterização e perspectivas. II ed. Brasília, SEMATEC/EdUnB, p. 171-188.

ASSIS,J.S. \& SILVA,S.B (1982) Estudo fitossociológico. In: Vegetação, PROJETO RADAMBRASIL, Folha SD.23 - Brasilia, Rio de Janeiro, p. 463-494

BARBERI,M. (1988) Levantamento do potencial arqueológico da UHE rio do Peixe. Instituto Goiano de Pré-História e Antropologia, Goiânia, relatório interno, $84 \mathrm{p}$.

BARBERI,M. (1994) Paleovegetação e paleoclima no Quaternário tardio da Vereda de Águas Emendadas/DF. Brasília, 136 p. Dissertação de Mestrado - Instituto de Geociências, Universidade de Brasília.

BARBERI,M. (1998) História ecológica de Águas Emendadas/DF. SEMINÁRIO PESQUISA EM UNIDADES DE CONSERVAÇÄO. Brasilia, 1998. Anais, SEMATEC, p. 153-170.

BARBERI,M.; SALGADO-LABOURIAU,M.L.; SUGUIO,K.; MARTIN,L.; TURCQ,B.; FLEXOR,J.M. (1995) Análise palinológica da vereda de Águas Emendadas/DF. In: V CONGRESSO DA ASSOCIAÇÃO BRASILEIRA DE ESTUDOS DO QUATERNÁRIO, 1995, Niterói. Anais do $V$ Congresso ABEQUA, São Paulo, ABEQUA, v.1, p. 10-17.

BARBERI,M.; SALGADO-LABOURIAU,M.L.; SUGUIO,K. (2000) Paleovegetation and paleoclimate of "Vereda de Águas Emendadas", central Brazil. Journal of South American Earth Sciences. 13:241-254. 
BARBOSA,A.S. Povoadores dos Cerrados. Goiânia, Ed. Univ. Católica de Goiás, 456 p. (no prelo).

BARBOSA,A.S.; SCHMITZ,P.I. (1998) Ocupação indígena no cerrado. In: SANO,S.M. \& ALMEIDA,S.P. Cerrado: ambiente e flora. Planaltina, SEMATEC/CPAC, p. 3-46.

BARBOSA,A.S.; BARBERI,M.; SCHMITZ,P.I. (1994) Cultura e ambiente nas áreas do sudoeste de Goiás. In: NOVAIS PINTO,M. Cerrado: caracterização, ocupação e perspectivas. II ed. Brasília, SEMATEC/EdUnB, p. 75-108.

BARRETO,A.M.F. (1996) Interpretação paleoambiental do sistema de dunas fixadas do médio Rio São Francisco. São Paulo, 174 p. Dissertação de Mestrado - Instituto de Geociências, Universidade de São Paulo.

BARRETO,A.M.F.; PESSENDA,L.C.R.; SUGUIO,K. (1996) Probable drier Holocene climate evidence by charcoal bearing Middle São Francisco River paleodunes, state of Bahia, Brazil. An. Acad. Bras. Cien. 68 (Supl. 1):43-48.

BEHLING,H. (1998) Late Quaternary vegetational and climatic changes in Brazil. Review of Palaeobotany and Palynology, 99:1143-1156.

BEHLING,H. \& HOOGHIEMSTRA,H. (1998) Late Quaternary palaeoecology and palaeoclimatology from pollen records of the savannas of the Llanos Orientales in Colombia. Palaeogeography, Palaeoclimatology, Palaeoecology, 139:251-267.

BEHLING,H. \& HOOGHIEMSTRA,H. (1999) Environmental history of Colombian savannas of the Llanos Orientales since the Last Glacial Maximum from lake records El Pinal and Carimagua. Journal of Paleolimnology, 21:461476.

BELTRÃO,M.C.; LEME,S.M.N.; ANDRADE,C.C.; DÓRIA,F.M. (1991) Projeto Central: Primeiros resultados. Clio, 4:39-47.

BERTAUX,J.; LEDRU,M.P.; SOUBIĖS,F.; SONDAG,F. (1996) The use of quantitative mineralogy linked to palynological studies in paleoenvironmental reconstruction: the case study of the "Lagoa Campestre"lake, Salitre, Minas Gerais, Brazil. C.R. Acad. Sci. Paris, 323(II):65-71.

BIGARELLA,J.J.; BECKER,R.D.; SANTOS,G.F. (1994) Estrutura e origem das paisagens tropicais e subtropicais. Florianópolis, Editora UFSC, $435 \mathrm{p}$.

BRADBURY,J.P.; LEYDEN,B.; SALGADO-LABOURIAU,M.L.; LEWIS JR,W.M.; SCHUBERT,C.; BENFORD,M.W.; FREY,D.G.; WHITEHEAD,D.R.; WEIBEZAHN,F.H. (1981) Late Quaternary environmental history of Lake Valencia, Venezuela. Science, 214:1299-1305. 
CESAR,H.L. (1980) Efeito da queima e corte sobre a vegetação de um Campo Sujo na Fazenda Água Limpa. Brasília, 123 p. Dissertação de Mestrado Instituto de Biologia, Universidade de Brasilia.

CLAPPERTON,C. (1993) Nature of environmental changes in South America at the Last Glacial Maximum. Palaeogeography, Palaeoclimatology Palaeoecology, 101:189-209.

COLINVAUX,P.A.; DE OLIVEIRA,P.E.; MORENO,J.E.; MILLER,M.C.; BUSH,M.B. (1996) A long pollen record from Lowland Amazonia: Forest and cooling in glacial times. Science, 274:85-88.

COLINVAUX,P.A.; DE OLIVEIRA,P.E.; BUSH,M.B. (2000) Amazonian and neotropical plant communities on glacial time-scales: The failure of the aridity and refuge hypotesis. Quaternary Science Reviews, 19:141-169.

CORDEIRO,P.C. (1995) Mudanças paleoambientais e ocorrência de incêndios nos últimos 7.400 anos na região de Carajás, Pará. Niterói, 115. Dissertação de Mestrado - Instituto de Química, Universidade Federal Fluminense.

COUTINHO,L.M. (1990) Fire in the ecology of the Brazilian Cerrado. In: GOLDAMMER,J.G. Fire in the Tropical Biota-Ecosystem Process and Global Challenges. Springer-Verlag Ecological Studies, 84:82-105.

DALY,D.C. \& PRANCE,G.T. (1989) Brazilian Amazon. In: CAMPBELL,D.G. \& HAMMOND,F. Floristic inventory of tropical countries. New York, New York Botanical Garden, p. 401-426.

DAMBRÓS,L.A.; DIAS,A.A.; FONZAR,B.C. (1981) As regiões fitoecológicas, sua natureza e seus recursos econômicos; estudo fitogeográfico. In: PROJETO RADAMBRASIL, Folha SD-22-Goiás, Rio de Janeiro, p. 509-560.

DARDENNE,M.A. (1979) Os grupos Paranoá e Bambuí na Faixa Dobrada Brasília. In: SIMPÓSIO SOBRE O CRÁTON DO SÃO FRANCISCO E SUAS FAIXAS MARGINAIS, 1, Salvador. Anais .., Salvador, SBG, p. 140157.

DAVIS,M.B. (1966) Determination of absolute pollen frequency. Ecology, 147:310311.

DE OLIVEIRA,P.E. (1992) A palynological record of late Quaternary vegetational and climatic change in Southeastern Brazil. Tese de Doutorado, Ohio State University, $242 \mathrm{p}$.

DE OLIVEIRA,P.E. (1996) Glacial cooling and forest desequilibrium in Western Amazonia. An. Acad. Bras. Cien., 68 (Supl. 1):129-138. 
DE OLIVEIRA,P.E.; BARRETO,A.M.F.; SUGUIO,K. (1999) Late Pleistocene Holocene climatic and vegetational history of the Brazilian caatinga: the fossil dunes of the middle São Francisco River. Palaeogeography, Palaeoclimatology, Palaeoecology, 145:319-337.

DIAS,B.F.S. (1992) Cerrados: uma caracterização. In: DIAS,B.F.S. Alternativa de desenvolvimento dos cerrados: manejo e consenvação dos recursos naturais renováveis. Brasília, IBAMA, p. 11-25.

DILLEHAY,T.D. (1997a) Onde estão os remanescentes ósseos humanos do final do Pleistoceno: Problemas e perspectivas na procura dos primeiros americanos. Revista USP, 34:22-33.

DILLEHAY,T.D. (1997b) Monte Verde: a Late Pleistocene settlement in Chile 2: The archaeological context. Washington (DC), Smithsonian. Institution Press, 26p.

EITEN,G. (1982) Brazilian "savannas". In: HUNTLEY,B.J. \& WALKER,B.H. Ecological Studies, 42: Ecology of Tropical Savannas. New York, SpringerVerlag Berlin/Heidelberg New York, p. 25-47.

EITEN,G. (1986) The use of term "savanna". Trop. Ecol., 27:10-23.

EITEN,G. (1987) Physiognomic categories of vegetation. In: MIYAWAKI,A.; BOGENRIEDER,A.; OKUDA,S.; WHITE,J. Vegetation ecology and creation of new environments. Tokyo, Tokai Univ. Press, p. 387-403.

EITEN,G. (1994) Vegetação do cerrado. In: NOVAIS PINTO,M. Cerrado: Caracterização, ocupação e perspectivas. II ed. Brasilia, EdUnB/SEMATEC, p. 17-74.

EMBRAPA (1983) Levantamento do reconhecimento de baixa intensidade dos solos e aptidão agrícola das terras de parte da região geoeconômica de Brasília. Boletim de Pesquisa, 24, SNLS, Rio de Janeiro, 515 p.

EMBRAPA (1998) Cerrado: ambiente e flora. SANO,S.M.; ALMEIDA, S.P. (eds), Planaltina, EMBRAPA/CPAC, $556 \mathrm{p}$.

ERDTMAN,G. (1952) Pollen morphology and plant taxonomy: Angiosperms. Almqvist \& Wikseel, Stockholm, $539 \mathrm{p}$.

ERDTMAN,G. (1960) The acetolysis method: a revised description. Svensk, Botanisk, Tidskrift, 54(4):561-564.

FAEGRI,K. \& IVERSEN,P. (1950) Text-book of modern pollen analysis. Ejnar Munksgaard, Copenhagen, $168 \mathrm{p}$.

FAEGRI,K.; KALAND,P.E.; KRZYWINSKI,K. (1989) Text-book of pollen analysis. IV ed. John Wiley e Sons, New York, 328 p. 
FARIA,A. (1995) Estratigrafia e sistemas deposicionais do Grupo Paranoá nas áreas de Cristalina, Distrito Federal e São João d'Aliança -'Alto Paraíso de Goiás. Dissertação de Mestrado, 199p. Instituto de Geociências da Universidade de Brasília, inédito.

FEIFILI,J.M. (1998) A Estação Ecológica de Águas Emendadas no contexto fitogeográfico do cerrado. In: PESQUISA EM UNIDADES DE CONSERVAÇÃo I, Brasília, 1998. Anais.Brasilia, IEMA/SEMATEC, p. 7188.

FERRAZ-VICENTINI,K.R. (1993) Análise palinológica de uma vereda em Cromínia, GO. Brasília, 136 p. Dissertação de Mestrado - Instituto de Ciências Biológicas, Universidade de Brasília.

FERRAZ VICENTINI,K.R. (1999) História do fogo no cerrado: uma análise palinológica. Brasília, 208 p. Tese de Doutorado - Instituto de Ciências Biológicas, Universidade de Brasília.

FERRAZ-VICENTINI,K.R. \& SALGADO-LABOURIAU,M.L. (1996) Palynological analysis of a palm swamp in Central Brazil. Journal of South American Earth Sciences, 9(3/4):207-219.

FERRI,M.G. (1979) Uma década de trabalhos no Cerrado. In: FERRI,M. \& GOODLAND, R. Ecologia do Cerrado. São Paulo, Ed. Universidade de São Paulo, p. 23-59.

FILGUEIRAS,T.S. \& PEREIRA,B. (1994) Flora. In: NOVAIS PINTO,M. Cerrado: Caracterização, Ocupação e Perspectivas. II ed. Brasília, EdUnB/ SEMATEC, p. 345-404.

FONZAR,C.B (1978) Delimitação das sub-regiões bioclimáticas do Centro Oeste. Projeto RADAMBRASIL, Relatório interno, Goiânia, 9 p.

FREITAS-SILVA,F.H. \& CAMPOS,J.E.G. (1998) Geologia do Distrito Federal. In: IEMA/SEMATEC/UnB. Inventário Hidrogeológico e dos Recursos Hidricos Superficiais do Distrito Federal. Brasília, IEMA/SEMATEC/EdUnB. Vol. 1(1): $86 \mathrm{p}$.

FUCK,R. (1994) A Faixa Brasilia e a Compartimentação Tectônica na Província Tocantins. In: SIMPÓSIO DE GEOLOGIA DO CENTRO-OESTE, 4, Brasília. Atas, Brasília: SBG, p. 184-187.

FUCK,R.; JARDIM DE SÁ,E.F.; PIMENTEL,M.M.; DARDENNE,M.A.; PEDROSA SOARES,A.C. (1993) As faixas de dobramentos marginais do Cráton do São Francisco: Sintese dos conhecimentos. In: DOMINGUEZ,J.M.L. \& MISI,A. O Cráton do São Francisco. Salvador: SBG/SGM/CNPq, p.161185. 
GIULIETTI,A.M. \& FORERO,E. (1990) Diversidade taxonômica das angiospermas brasileiras. Acta bot. Bras. 4(1):3-10.

GOMES,C.F. (1988) Argilas, o que são e para que servem. Calouste Gulbekian, Lisboa, $457 \mathrm{p}$.

GRIMM,E.C. (1987) CONISS: A Fortran 77 program for stratigraphically constrained cluster analysis by the method of the incremental sum of squares. Pergamon Joumal, 13:13-35.

GUIDON,N. (1984) As primeiras ocupações humanas da área arqueológica de São Raimundo Nonato, Piauí. Revista de Arqueologia, 2(1):38-46.

GUIMARÃES,E.M. (1997) Estudos de proveniência e diagênese com ênfase na caracterização dos filossilicatos dos Grupos Paranoá e Bambuí na região de Bezerra Cabeceiras. Brasília, 269 p. Tese de Doutorado - Instituto de Geociências, Universidade de Brasília.

GUIMARÃES,E.M. (1999) Difratometria de raios-X. In: XXVII CONGRESSO BRASILEIRO DE CIÊNCIAS DO SOLO. Brasília, Texto de Mini-Curso, 22p., inédito.

GUIMARÃES,J.G. (1982) Estudo Fitossociológico. In: Vegetação - PROJETO RADAMBRASIL, Folha Sd.23- Brasilia, Rio de Janeiro, p. 494-519.

HAQ,B.V.; HARDENBOL,J.; VAIL,P.R. (1987) Cronology of fluctuating sea levels since the Triassic. Science, 235:1156-1166.

HAYS,J.D. \& PITMAN III,W.C. (1973) Lithospheric plate motion, sea level changes and climatic and ecological consequences. Nature, 246(2):18-22.

HARIDASAN,M. (1994) Solos. In: NOVAES PINTO, M. Cerrado: Caracterização, Ocupação e Perspectivas. Il ed. Brasília, EdUnB/SEMATEC, p. 321-344.

HEUSSER,C.J. (1971) Pollen and Spores of Chile. The University of Arizona Press, $167 \mathrm{p}$.

HOOGHIEMSTRA,H. (1984) Vegetational and climatic history of the high plain of Bogota, Colombia: a continuous record of the last 3,5 million years. J.Cramer, Valduz, $368 \mathrm{p}$.

HOOGHIEMSTRA,H. \& VAN DER HAMMEN,T. (1993) Late Quaternary and paleoecology of Laguna Pedro Palo (subandean forest belt, Eastern Cordillera, Colombia). Review of Palaeobotany and Palynology, 77:235262.

HOOGHIEMSTRA,H. \& VAN DER HAMMEN,T. (1998) Neogene and Quaternary development of the neotropical rain forest: the forest refugia hypothesis, and a literature overview. Earth-Science Reviews, 44:147-183. 
HOORN,C.; GUERRERO,J.; SARMIENTO,G.A.; LORENTE,M.A. (1995) Andean tectonics as a cause for changing drainage patterns in Miocene northern South America. Geology, 23(3):237-240.

IBGE (1990) Diagnóstico Brasil: a ocupação do território e o meio ambiente. Rio de Janeiro, IBGE, 138 p.

IRIONDO,M. \& LATRUBESSE,E.M. (1994) A probable scenario for a dry climate in Central Amazonia during the Late Quaternary. Quaternary International, 21:121-128.

JOLY,A.B. (1963) Gêneros de algas de água doce da cidade de São Paulo e arredores. Rickia, Série Criptogâmica dos Arquivos de botânica do Estado de São Paulo. Instituto de Botânica, Suplemento 1, 188 p.

JOLY,A.B. (1979) Botânica: Introdução à taxonomia vegetal. V ed. Companhia Editora Nacional, São Paulo,777 p.

KNIPIS,R. (1998) Early hunter-gatherers in the Americas: perspectives from central Brazil. Antiquity, 72:581-592.

KRAUSKOPF,K.B. (1979) Introduction to Geochemistry. Kogakusha, McGraw-Hill, $617 \mathrm{p}$.

KREJCI,L.C.; FORTUNATO,F.F.; SOARES-CORREA,P.R. (1982) Pedologia: Levantamento exploratório dos solos. In: PROJETO RADAMBRASIL, Folha SD-23 Brasilia, p. 297-440.

LACERDA FILHO,J.V.; REZENDE,A.; SILVA,A. (1999) Geologia e recursos minerais do Estado de Goiás e Distrito Federal. Goiânia: CPRM, 176 p.

LEDRU,M.P. (1991) Etude de la pluie pollinique actuelle des forets du Brésil central: climat, vegetation, application a l'étude de l' évolution paleoclimatique des 30000 dernières années. Paris, 193 p. Tese de Doutorado - Soutenue.

LEDRU,M.P. (1993) Late Quaternary environmental and climatic changes in Central Brazil. Quaternary Research, 39:90-98.

LEDRU,M.P.; BEHLING,H.; FOURNIER,M.; MARTIN,L. (1994) Localisation de la forêt $\mathrm{d}^{\prime}$ Araucaria du Brésil au cours de I' Holocene, Implications paléoclimatiques. Comptes Rendus I' Academie Sciences, Paris, Sciences de la Vie, 317:517-531.

LEDRU,M.P.; BRAGA,P.I.S.; SOUBIES,F.; FOURNIER,M.; MARTIN,L.; SUGUIO,K., TURCQ,B. (1996) The last 50,000 years in the Neotropics (Southern Brazil): evolution of vegetation and climate. Palaeogeography, Palaeoclimatology, Palaeoecology, 123:239-257. 
LEDRU,M.P.; SALGADO-LABOURIAU,M.L.; LORSCHEITER,M.L.

Vegetation dynamics in southern and central Brazil during the last 10,000 yr BP. Review of Palaeobotany and Palynology, 99:131-142.

LORENZI,H. (1992) Árvores brasileiras., Nova Odessa, Ed. Plantarum, 352 p.

LORENZI,H. (1998) Árvores Brasileiras. Nova Odessa, Ed. Plantarum, v. 2, 352p.

MAMEDE,L. (1993) Compartimentação geomorfológica da Região Centro-Oeste. Boletim SBG-NCO, 16:107-144.

MAMEDE,L. (1995) Dinâmica do Ambiente. In: Zoneamento Ambiental da Bacia do Córrego Taquara - Distrito Federal. Goiânia: IBGE/DGC/DIGEO-CO, Rio de Janeiro, v. 2, p. 195-199.

MAMEDE,L. (1996) O significado das coberturas terciárias nas chapadas da região Centro-Oeste. In: SIMPOSIO NACIONAL DE GEOMORFOLOGIA, 1. Sociedade \& Natureza, Uberlândia, 8(15):26-30.

MAMEDE,L. (1999) Análise e Interpretação Geomorfológica da Bacia do Córrego Taquara-DF. São Paulo, 310 p. Tese de Doutorado - Faculdade de Filosofia, Letras e Ciências Humanas, Universidade de São Paulo.

MAMEDE,L. \& PEREIRA,B.A.S. (1995) Zoneamento Ambiental da Bacia do Córrego Taquara, Distrito Federal. Goiânia: IBGE/DGC/DIGEO-CO, v.1, $87 p$.

MAMEDE,L.; ROSS,J.L.S.; SANTOS,L.M.; NASCIMENTO,M.A.L.S. (1983) Geomorfologia. In: PROJETO RADAMBRASIL. Folha SE.22 Goiânia, Levantamento de Recursos Naturais v. 31, p. 349-412.

MARCHANT,R.; HOOGHIEMSTRA,H.; SALGADO-LABOURIAU,M.L.; (em preparação) Parent Plants of Latin America Pollen. Amsterdan, Laboratory Hugo d'Vriès.

MARKGRAF,V. \& D' ANTONI,H.L. (1978) Pollen flora of Argentina: Modern spores and pollen types of Pteridophyta, Gimnospermae and Angiospermae. Tucson, Arizona, The University of Arizona Press, 208 p.

MARTIN,L. \& FLEXOR,J.M. (1989) Vibro-testemunhador leve: Construção, utilização e possibilidades. II CONGRESSO DA ASSOCIAÇÃO BRASILEIRA DE ESTUDOS DO QUATERNÁRIO, Publicação especial, $n^{\circ}$ $1: 15 \mathrm{p}$.

MARTIN,L. \& SUGUIO,K. (1992) Variation of coastal dynamics during the last 7,000 years recorded in beach ridge plains associated with river mouths: example from the central Brazilian coast. Palaeogeography, Palaeoclimatology, Palaeoecology, 99:119-140. 
MARTIN,L.; MÖRNER,N.A.; FLEXOR,J.M.; SUGUIO,K. (1986) Fundamentos e reconstrução de antigos niveis marinhos do Quaternário. Bol. IG-USP, Public. Especial, 4:1-161.

MARTIN,L.; FOURNIER,M.; MOURGUIART,P.; SIFEDDINE,A.; TURCQ,B.; ABSY,M.L.; FLEXOR,J.M. (1993) Southern Oscillation Signal in South American Palaeoclimatic data of the last 7,000 years. Quaternary Research, 39:338-346.

MARTIN,L. BERTAUX,J.; LEDRU,M.P.; MOURGUIART,P.; SIFEDDINE,A.; SOUBIĖS,F.; TURCQ,B. (1995) Perturbaciones del régimen de las lluvias y condiciones de tipo el Niño en América del sur Tropical desde hace 7000 años. Bull. Inst. Fr. études andines, 24(3):595-605.

MARTIN,L.; BERTAUX,J.; CORREGE,T.; LEDRU,M.P.; MOURGUIART,P.H.; SIFEDDINE,A.; SOUBIĖS,F.; SUGUIO,K.; TURCQ,B. (1997) Insolation control on rainfall decoupling in Tropical South America between 12,400 and 8,800 cal years BP. Quaternary Research, 47:117-122.

MAURO,C.A.; DANTAS,M.; ROSO,F.A. (1982) Geomorfologia . In: PROJETO RADAMBRASIL. Folha Sd.23 Brasília. Rio de Janeiro, Levantamento de Recursos Naturais v. 29, p. 205-296.

MELTZER,D. (1996) Monte Verde and the Pleistocene peopling of the Americas. Science, 276: 754-756.

MENDONÇA,R.C.; FEIFILI,J.M.; WALTER,B.M.T.; SILVA JR,M.C.; REZENDE,A.V.; FILGUEIRAS,T.S.; NOGUEIRA,P.E. (1998) Flora Vascular do Cerrado. In: SANO,S.M. \& ALMEIDA,S.P. Cerrado, ambiente e flora. Planaltina, EMBRAPACPAC, p. 289-556.

MOORE,P.D. \& WEBB,J.A. (1978) An Illustrated Guide to Pollen Analysis. London, Hodder and Stoughton, $133 \mathrm{p}$.

MURILLO,M.T. \& BLESS,M.J.M. (1974) Spores of recent colombian Pteridophyta I. Trilete Spores. Review of Palaeobotany and Palynology, 18:223-269.

MURILLO,M.T. \& BLESS,M.J.M. (1978) Spores of recent Colombian Pteridophyta II. Monolete Spores. Review of Palaeobotany and Palynology, 25:29-35.

NEVES,W.; ZANINI,M.C.; MUNFORD,D.; PUCCIARELLI,H.M. (1997) O povoamento da América à luz da morfologia craniana. Revista USP, 34:96105.

NIMER,E. (1989) Climatologia do Brasil. II ed. Rio de Janeiro, IBGE, 421 p.

OLIVEIRA-FILHO,A.T. \& RATTER,J. (1995) A study of the origin of Central Brazilian Forests by the analysis of Plant Species Distribuition Patterns. Edinb. J. Bot., 52(2):195-203. 
PARIZZI,M.G. (1993) A Gênese e a dinâmica da Lagoa Santa com base em estudos palinológicos, geomorfológicos e geológicos de sua bacia. Belo Horizonte, 103 p. Dissertação de Mestrado - Instituto de Geociências, Universidade Federal de Minas Gerais.

PARIZZI,M.G.; SALGADO-LABOURIAU,M.L.; KOHLER,H.C. (1998) Genesis and environmental history of Lagoa Santa, southeastern Brazil. The Holocene, 8(3): 311-321.

PEREIRA,R.F. \& FREITAS,E.M. (1982) Climatologia. In: PROJETO RADAMBRASIL, Folha Sd.23 Brasília. Rio de Janeiro, Levantamento de Recursos Naturais v. 29, p. 626-644.

PEREIRA,B.A.S.; MENDONÇA,R.C.; FILGUEIRAS,T.S.; PAULA,J.E.; HERINGER,E.P. (1990) Levantamento Florístico da Área de Proteção Ambiental (APA) da Bacia do Rio São Bartolomeu, Distrito Federal. In: XXXVI CONGRESSO BRASILEIRO DE BOTÂNICA, Curitiba, 1983. Anais, Brasília, IBAMA, v. 1, p. 419-492.

PIRES,J.M. (1984) The Amazonian forest. In: H. SIOLI,H. The Amazon: Limnology and landscape ecology of a mighty tropical river and its basin. Dordrecht, $\mathrm{p}$. $581-602$.

PISIAS,N.G. \& IMBRIE,J. (1987) Orbital geometry, $\mathrm{CO}_{2}$ and Pleistocene Ciimat. Oceanus, 29(4):43-49.

PROUS,A. (1991) Arqueologia brasileira. Brasília, Editora UnB, 605 p.

PROUS,A. (1997) O povoamento da América visto do Brasil: uma perspectiva crítica. Revista USP, 34:8-21.

PUNT,W.; BLACKMORE,S.; NILSSON,S.; THOMAS,A. (1994) Glossary of Pollen and Spores Terminology. LPP Foundation, Utrecht, series n.1, 71 p.

RATTER,J.A. (1991) The conservation situation of the Brazilian cerrado vegetation. Report for World Wildlife Found (WWF). Edinburgh, Royal Botanical Garden, $19 \mathrm{p}$.

RATTER,J.A. (1994) Vegetação. In: NOVAIS PINTO,M. Cerrado: Caracterização, ocupação e perspectivas. Il ed. Brasília, SEMATEC/EdUnB, p. 17-74.

RATTER,J.A. \& DARGIE,T.C.D. (1992) An analysis of the floristic composition of 26 cerrado areas in Brazil. EdUnB/J. Bot. 49(2):235-250.

RAWITSCHER,F. (1948) The water economy of the vegetation of the Campos Cerrados in Southern Brazil. Jour. Ecol., 36(2):237-268. 
RIBEIRO,J.F. \& WALTER,B.M.T. (1998) Fitofisionomias do Bioma Cerrado. In: SANO,S.M. \& ALMEIDA,S.P. Cerrado: ambiente e flora. Planaltina, EMBRAPA/CPAC, p. 89-168.

RIBEIRO,J.F.; SILVA,J.C.S.; BATMANIAN,G.J. (1985) Fitossociologia de tipos fisionômicos de Cerrado em Planaltina, DF. Revista Brasil. Botân. 8(2):131142.

RICHARDSON,I.B.K. (1978) Endemic taxa and the taxonomist. In: STREET,H.E. Essays in plant taxonomy. New York, New York Academic Press, p. 38-63.

RIZZINI,C.T. (1979) Tratado de fitogeografia do Brasil. Vol. 2. Aspectos sociológicos e florísticos, São Paulo, EDUSP, 273 p.

ROBERT,C. \& KENNETT,J.P. (1994) Antarctic subtropical humid episode at the Paleocene-Eocene boundary: Clay-mineral evidence. Geology, 22:211-214.

ROSHEVITZ,R.J. (1969) Evolução e sistemática das Gramíneas. Boletim do Instituto de Botânica, 5:1-20.

ROUBIK,D.W. \& MORENO,J.E. (1991) Pollen and Spores of Barro Colorado Island. Monographs in Systematic Botany, Panama, $270 \mathrm{p}$.

SALGADO-LABOURIAU,M.L. (1973) Contribuição à Palinologia dos Cerrados. Acad. Bras. De Ciências, Rio de Janeiro, 291 p.

SALGADO-LABOURIAU,M.L. (1979) Modern pollen deposition in the Venezuelan Andes. Grana, 18:53-68.

SALGADO-LABOURIAU,M.L. (1980) A pollen diagram of the PleistoceneHolocene boundary of Lake Valencia, Venezuela. Rev. Paleob. Palynol. 30:307-312.

SALGADO-LABOURIAU,M.L. (1984) Reconstruccion de los ambientes através de los granos de polen. Investigation y Ciencia (Spanish edition of the Scientific American), 96 septiembre, 3:6-17.

SALGADO-LABOURIAU,M.L. (1994) História Ecológica da Terra. II ed. São Paulo, Ed. Blücher, $326 \mathrm{p}$.

SALGADO-LABOURIAU,M.L. (1997) Late Quaternary paleoclimate in the savannas of South América. Journal of Quaternary Science, 12(5):371-379.

SALGADO-LABOURIAU,M.L. \& FERRAZ-VICENTINI,K.R. (1994) Fire in the cerrado 32,000 years ago. Curr. Res. Pleistocene, 11:85-87.

SALGADO-LABOURIAU,M.L. \& RULL,V. (1986) A method of introducing exotic pollen for palaeoecological analysis of sediments. Rev. Paleobot. Palynol. 47:97-103. 
SALGADO-LABOURIAU,M.L. \& SCHUBERT,C. (1977) Pollen analysis of peat bog from Laguna Vitória (Venezuelan Andes). Acta Cient. Venezolana 28:328332.

SALGADO-LABOURIAU,M.L.; SCHUBERT,C.; VALASTRO JR,S. (1977) Palaeoecological analysis of a Late Quaternary Terrace from Macubají, Venezuelan Andes. Journal Biogeography, 4:313-325.

SALGADO-LABOURIAU,M.L.; RULL,V.; SCHUBERT,C.; VALASTRO JR,S.; (1988) The establishment of vegetation after the Late Pleistocene deglaciation in the Páramo de Miranda, Venezuelan Andes. Review Palaeobotany and Palynology, 55(1-3):5-17.

SALGADO-LABOURIAU,M.L.; BRADLEY,R.S.; YURETICH,R.; WEINGARTEN,B. (1992) Palaeoecological analysis of the sediments of Lake Mucubaji, Venezuelan Andes. Journal of Biogeography, 19:317-327.

SALGADO-LABOURIAU,M.L.; CASSETI,V.; FERRAZ-VICENTINI,K.R.; MARTIN,L.; SOUBIES,F.; SUGUIO,K.; TURCQ,B. (1997) Late Quaternary vegetational and climatic changes in cerrado and palm swamp from Central Brazil. Palaeogeography, Palaeoclimatology, Palaeoecology, 128:215-226.

SALGADO-LABOURIAU,M.L.; $\quad$ BARBERI,M.; $\quad$ FERRAZ-VICENTINI,K.R.; PARIZZI,M.G. (1998) A dry climatic event during the late Quaternary of tropical Brazil. Review of Palaeobotany and Palynology. 99:115-129.

SALZANO,F.M. (1997) As origens extracontinentais dos primeiros americanos. Revista USP, 34: 34-43.

SARMIENTO,G. (1983) The savannas of tropical América. Tropical savannas. F. Bourliere (ed.), Amsterdam, Elsevier, p. 245-288.

SCHMITZ,P.I. (1994) Caçadores e coletores antigos. In: NOVAIS PINTO,M. Cerrado: Ocupação, caracterização e perspectivas. Il ed. Brasília, SEMATEC/EdUnB, p. 109-154.

SCHMITZ,P.I.; BARBERI,M.; BARBOSA,A.S.; BARBOSA,M.O.; MIRANDA,A.F. (1986) Caiapônia: Arqueologia nos cerrados do Brasil Central. Instituto Anchietano de Pesquisas, São Leopoldo, 334 p.

SCHMITZ,P.I.; BARBOSA,A.S.; JACOBUS,A.L.; BARBERI-RIBEIRO,M. (1989) Arqueologia nos cerrados do Brasil Central: Serranópiolis. Pesquisas (série antropologia), 44:1-208.

SEMATEC - SECRETARIA DO MEIO AMBIENTE CIÊNCIA E TECNOLOGIA (1996) Plano de Ação Emergencial Estação Ecológica de Águas Emendadas, Governo do Distrito Federal, Convênio IBAMA/IEMA No 058/95, $97 \mathrm{p}$. 
SIFEDDINE,A.; FROHLICH,F.; FOURNIER,M.; MARTIN,L.; SERVANT,M.; SOUBIĖS,B.T.; SUGUIO,K.; RIBEIRO,C.V. (1994) La sédimentation lacustre indicateur de changements des paléoenvironments au cour des 30.000 derniérs annés (Carajás, Amazonie, Brésil). Géociences de surface/ surface Géociences p. 1645-1652.

SILVA,R.T. (1995) Horticultores ceramistas do Planalto Central Brasileiro-Análise de 20 anos de pesquisas. Recife, 158 p. Dissertação de Mestrado - Instituto de História e Geografia, Universidade Federal de Pernambuco.

SOUBIES,F.; SUGUIO,K.; MARTIN,L.; LEPRUN,J.C.; SERVANT,M.; TURCQ,B.; FOURNIER,M.; DELAUNE,M.; SIFEDDINE,A. (1991) The Quaternary lacustrine deposits of the Serra dos Carajás (state of Para, Brazil). Ages and other preliminary results. Boletim IG-USP, 8:223-243.

SUGUIO,K. (1980) Rochas sedimentares. São Paulo, Ed. Edgard Blücher, 500p.

SUGUIO,K. (1999) Geologia do Quaternário e Mudanças Ambientais. São Paulo, Ed. Paulo's Comunicação e Artes Gráficas, 366 p.

SUGUIO,K.; ABSY,M.L.; FLEXOR,J.M.; LEDRU,M.P.; MARTIN,L.; SIFEDDINE,A.; SOUBIES,F.; TURCQ,B.; YBERT,J.P. (1993) The evolution of the continental and coastal environments during the last climatic cycle in Brazil (120 ky to Present). Boletim IG-USP, 24:27-41.

SUGUIO,K.; MARTIN,L.; TURCQ,B. (1996) Alteraçōes Climáticas no Quaternário. Boletim Climatológico. FCT/UNESP Ano 1, (2):43-50.

TURCQ,B.; SUGUIO,K.; MARTIN,L.; FLEXOR,J.M. (1993) Registros milenares nos sedimentos dos lagos da serra de Carajás. Ciência Hoje, 16:31-35.

TURCQ,B.; SIFEDDINE, A.; MARTIN,L.; ABSY,M.L.; SOUBIĖS,F.; SUGUIO,K.; VOLKMER-RIBEIRO,C. (1998) Amazonia rainforest fires: A lacustrine record of 7,000 years. Ambio, 27(2):139-142.

VAN DER HAMMEN,T. (1974) The Pleistocene changes of vegetation and climatic in tropical South America. Journal of Biogeography, 1:3-26.

VAN DER HAMMEN,T. (1991) Palaeoecology of the Neotropics: an overview of the state of affairs. Boletim IG-USP, Publicação Especial, 8:35-56.

VAN DER HAMMEN,T. \& ABSY,M.L. (1994) Amazonia during the last Glacial. Palaeogeography, Palaeoclimatology, Palaeoecology, 109:247-271.

VAN DER HAMMEN,T \& HOOGHIEMSTRA,H. (2000) Neogene and Quaternary history of vegetation, climate, and plant diversity in Amazonia. Quaternary Science Reviews, 19:725-742. 
VAN DER HAMMEN,T.; DUIVENVOORDEN,J.F.; LIPS,J.M.; YRREGO,L.E.; ESPEJO,N. (1992) Late Quaternary of the middle Caquetá River area (Colombian Amazonia). Journal of Quaternary Science, 7(1):45-55.

VAN GEEL,B. (1976) Paleoecological study of Holocene peat bog sections based on the analysis of pollen, spores, algae, macrophyte and zoological remains. Amsterdan, 75 p. Tese de Doutorado - Universidade de Amsterdam.

VAN GEEL,B. \& VAN DER HAMMEN,T. (1978) Zygnemataceae in Quaternary Colombian Sediments. Review of Palaeobotany and Palynology, 25:377392.

VASCONCELOS,P.M. (1996) Paleoclimas e evolução geomorfológica da região de Carajás: evidência geoquímica e geocronológica. In: SIMPOSIO DE GEOLOGIA DA AMAZÓNIA, Belém, p. 26-30.

VERNET,J.L.; WENGLER,L.; SOLARI,M.E.; CECCANTINI,G.; FOURNIER,M.; LEDRU,M.P.; SOUBIĖS,F. (1994) Feux, climats et végétations au Brésil central durant l'Holocene: les données d'un profil de sol à charbons de bois (Salitre, Minas Gerais). C.R. Acad. Sci. Paris, 319(II):1391-1397.

VON POST,L. (1967) Forest tree pollen in South Swedish peat bog deposits (Tradução para o inglês) Pollen et Spores, 9(3):375-401.

WARMING,E. (1908) Lagoa Santa. Contribuição para a geographia phytobiologica. Belo Horizonte, Imprensa Official do Estado de Minas gerais. (Tradução LÖEFGREN,A.) Reedição EDUSP, 1973, 1982, 386 p.

WWF (2000) Terrestrial ecoregions of the Neotropical realm. Washington, Conservation Science Program. (Escala 1:11.000.000).

YBERT,J.P.; SALGADO-LABOURIAU,M.L.; BARTH,M.O.; LORSCHEITTER,M.L.; BARROS,M.A.; CHAVES,S.A.M.; LUZ,C.F.P.; BARBERI-RIBEIRO,M.; SCHEEL,R.; FERRAZ-VICENTINI,K.R.; (1992) Sugestōes para padronização da metodologia empregada em estudos palinológicos do Quaternário. IG, São Paulo, 13(2):47-49. 


\section{ANEXO 1}

\section{Registro Fotogrảifico}
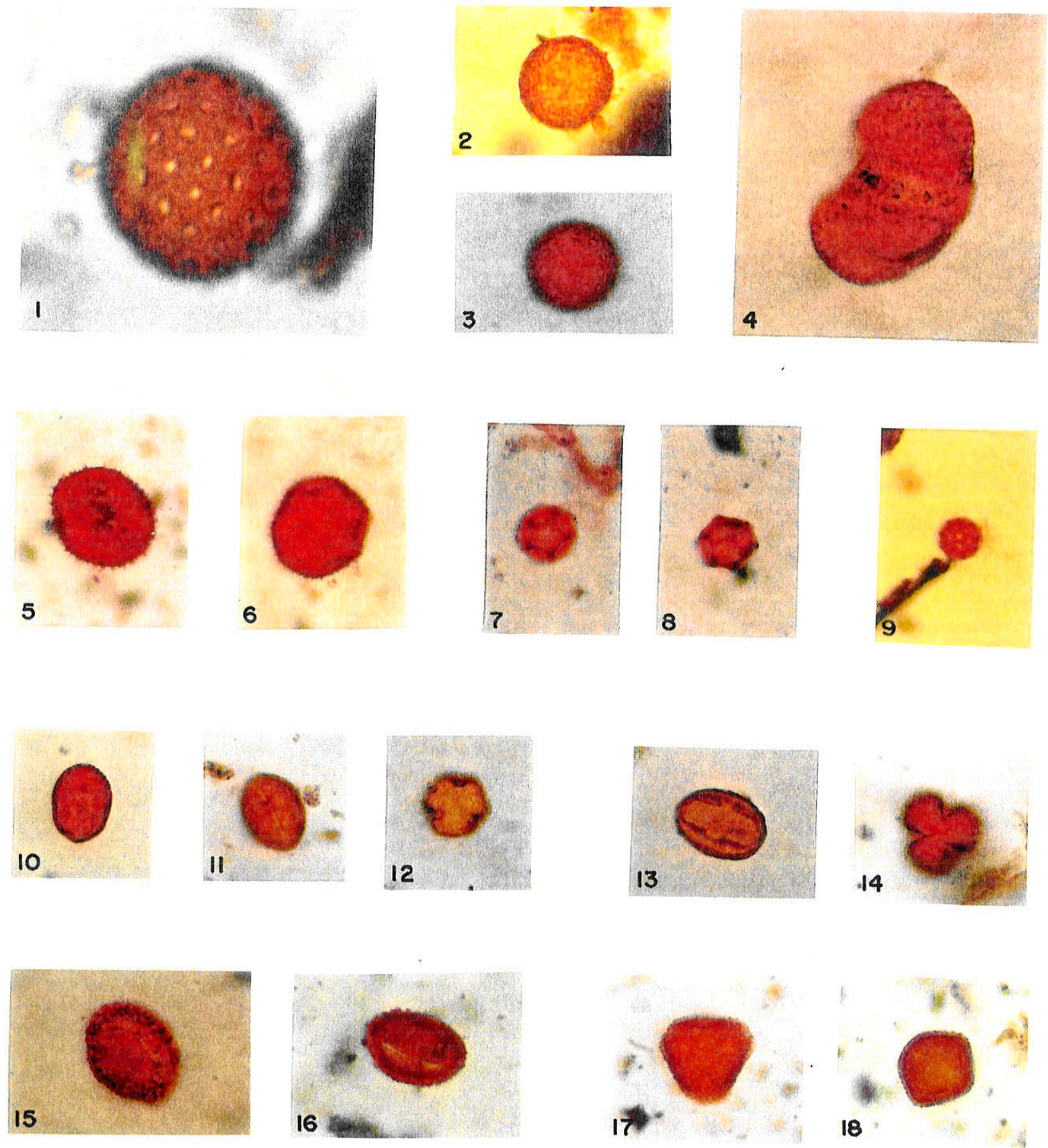

Prancha 1

Pólen Exótico: CHENOPODIACEAE - Kochia scoparia - 1 (X 100); 2 e 3 GYMNOSPERMAE - PODOCARPACEAE: 4 - Podocarpus ANGYOSPERMAE

ALISMATACEAE: 5 e 6 - Tipo 1054

AMARANTHACEAE: 7 e 8 - Alternanthera; 9 - Gomphrena

ANACARDIACEAE: 10, 11 e 12 - Lithrea; 13 e 14 - Tipo 1124

AQUIFOLIACAEAE: 15 e 16 - $\|$ ex

ARALIACEAE: 17 e 18 - Didymopanax 
Registro Fotográfico
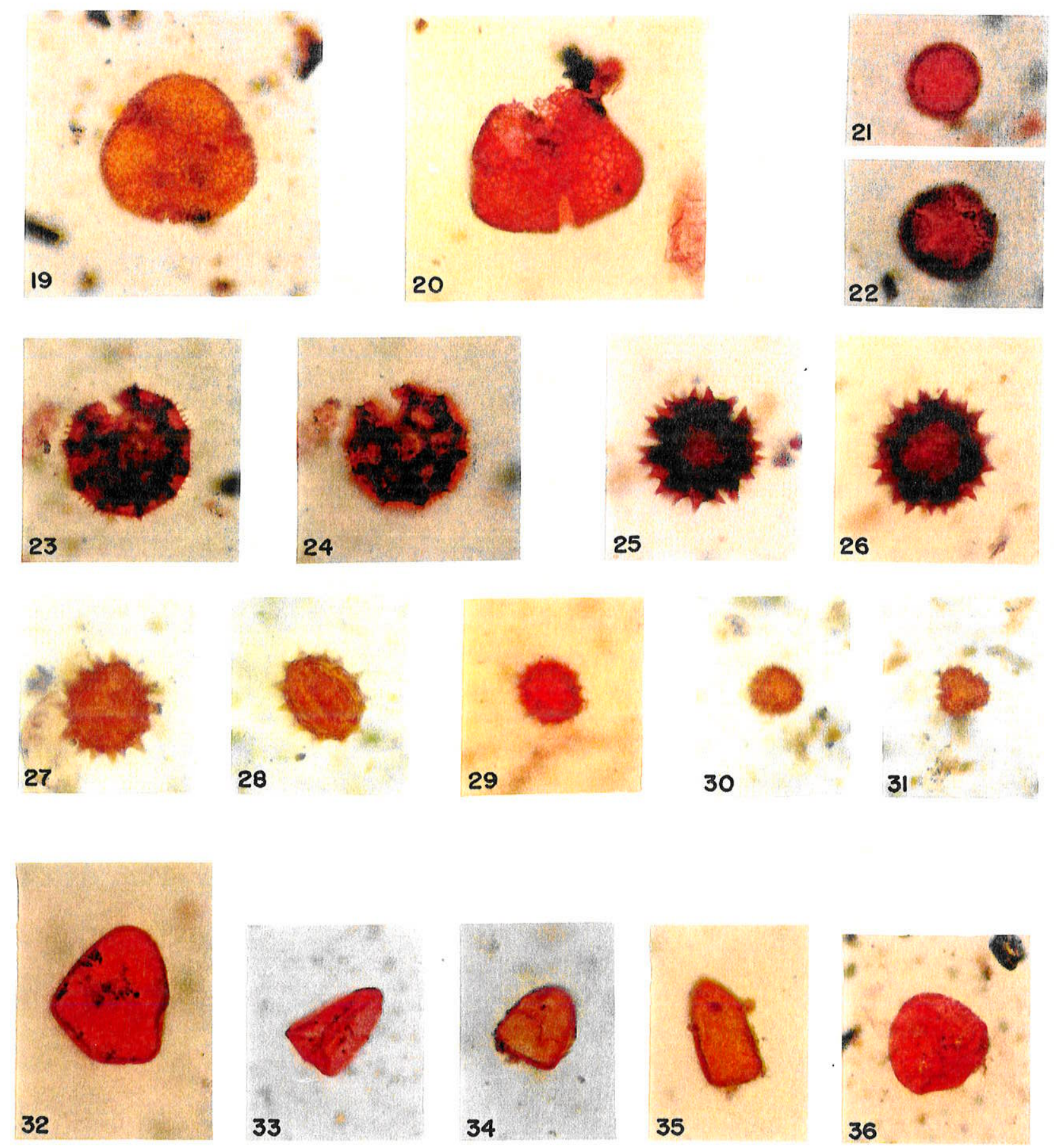

\section{Prancha 2}

BOMBACACEAE: 19 - Tipo 1195; 20 - Pseudobombax

CARYOPHYLLACEAE: 21 - Tipo 1193

CHLORANTHACEAE: 22 - Hedyosmum

COMPOSITAE (ASTERACEAE):

23 e 24 - Fenestrada; 25 e 26: Aspilia

27 e 28 - Tipo 1029; 29 - Tipo 1168; 30 e 31 - Tipo 1182

CYPERACEAE: $32 ; 33$; $34 ; 35$ e 36 
Rogistro Fotogråîịo

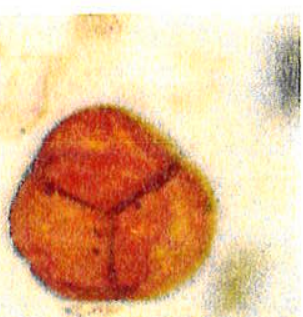

37
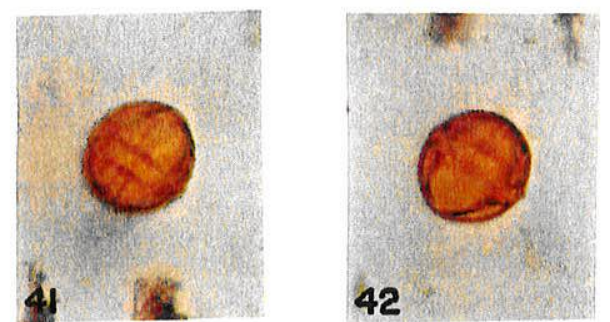

46

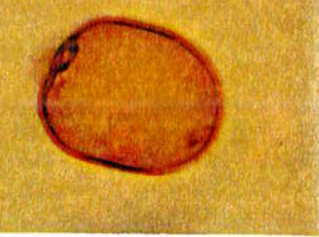

38
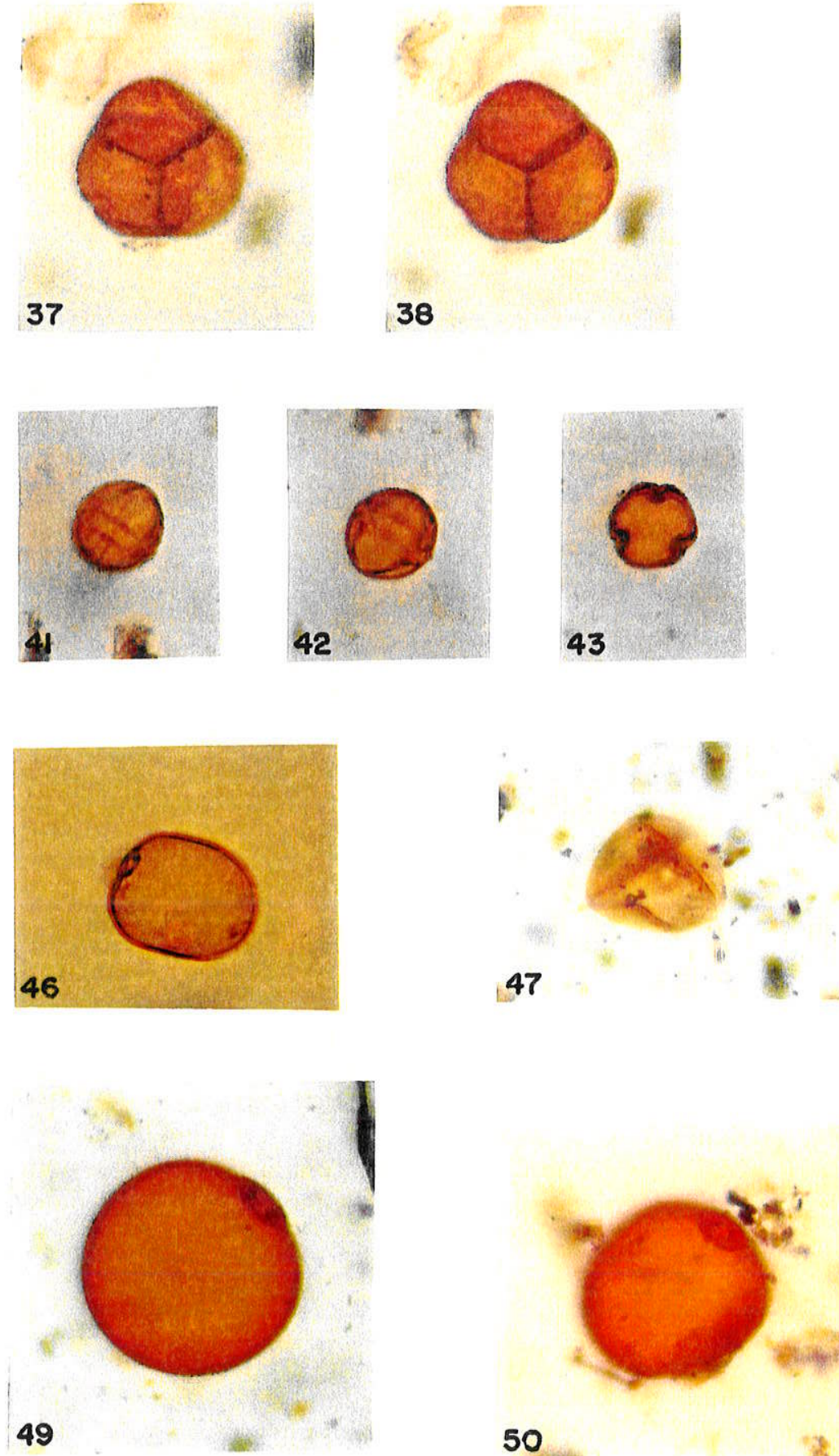

Prancha 3

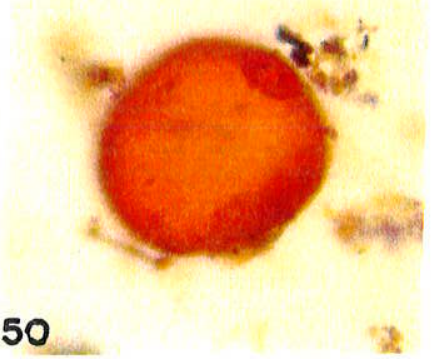

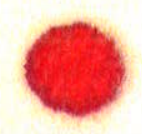

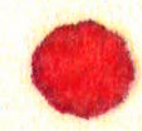

39

40
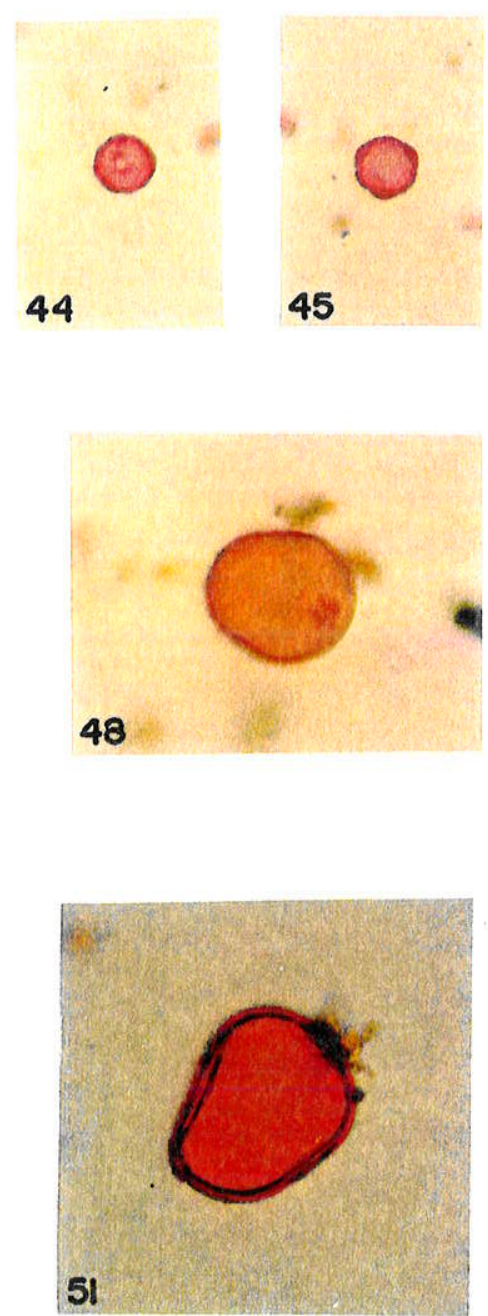

$(\times 40)$

ERICACEAE: 37 e 38 - Tipo 1196

ERIOCAULACEAE: 39 e 40 - Tipo 1006

ERYTHROXYLACEAE: 41; 42 e 43 - Erythroxylum

EUPHORBIACEAE: 44 e 45 - Acalypha

GRAMINEAE (POACEAE): 46; 47; 48; 49; 50 e 51 
Registro Fotogrảifico

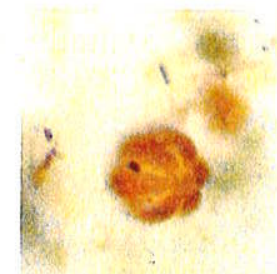

52
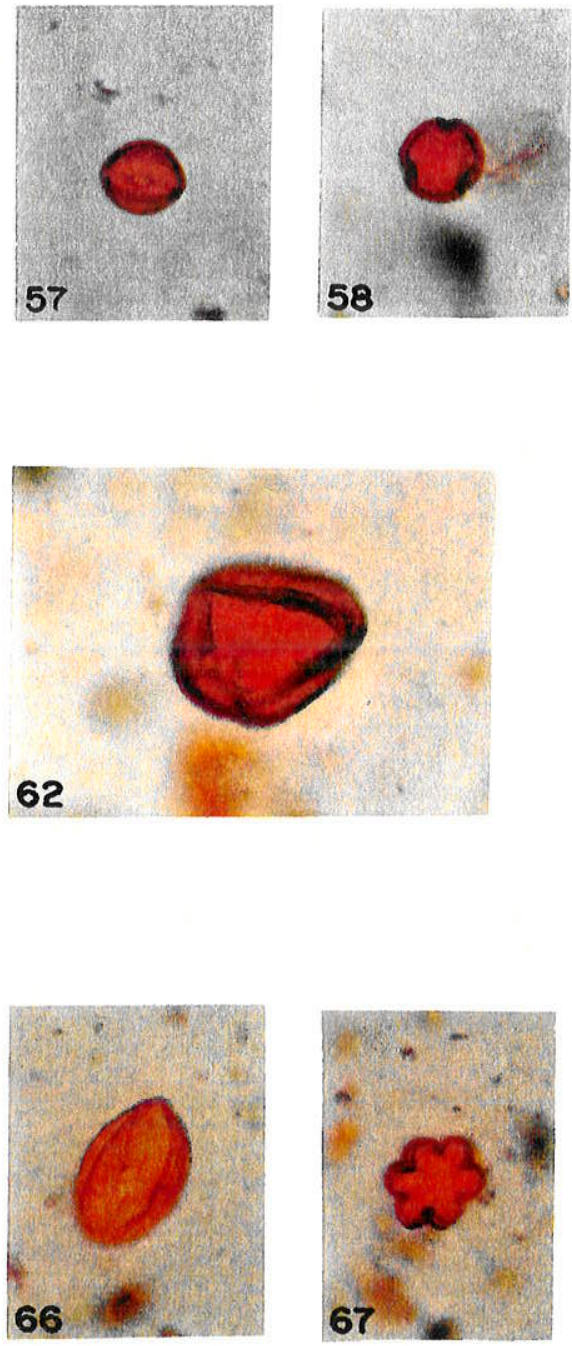
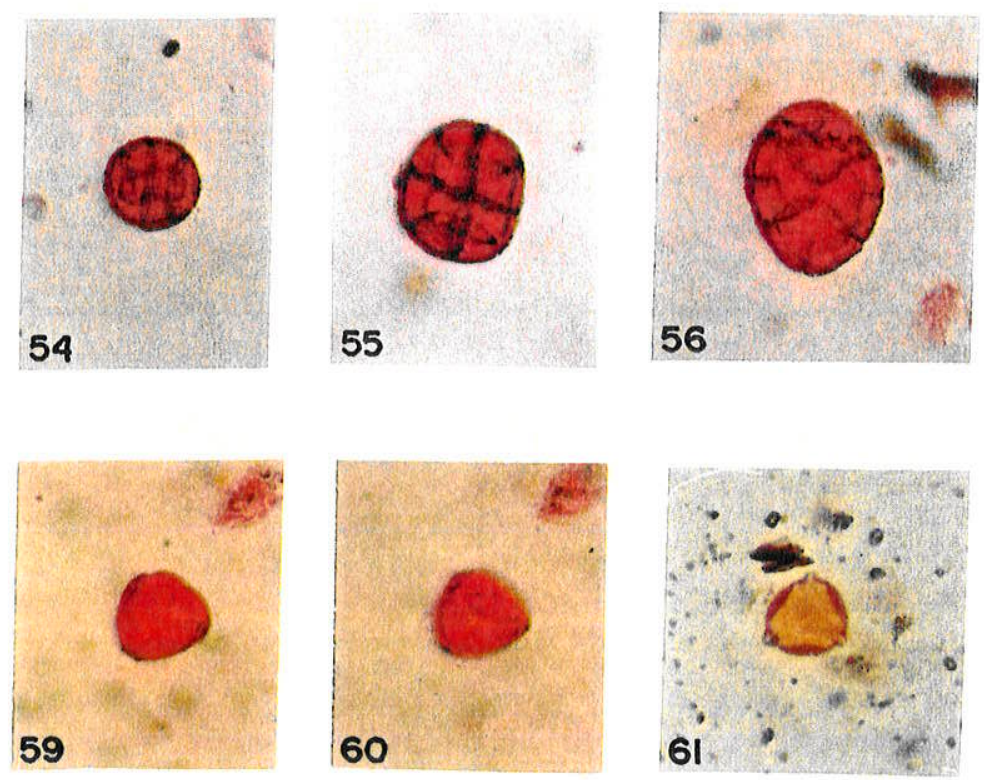

63
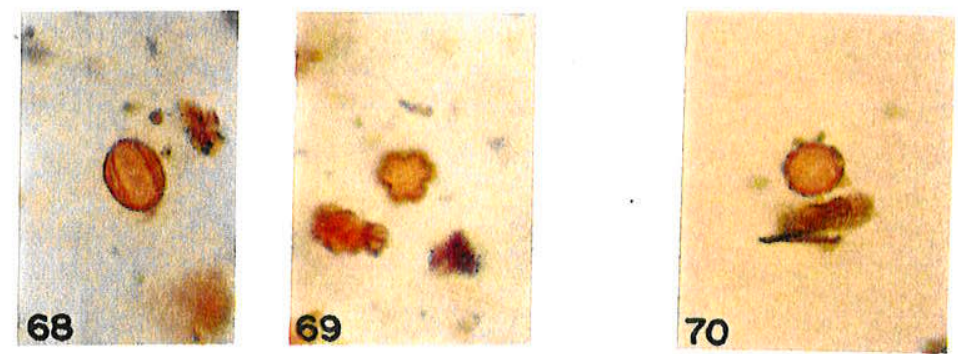

$(X 40)$

Prancha 4

LABIATAE (LAMIACEAE): 52 e 53 - Tipo 1197 LEGUMINOSAE: 54; 55 e 56 - Stryphnodendron LOGANIACEAE: 57 e 58 - Antonia ovata LYTHRACEAE: 59 e 60 - Tipo 1044; 61 - Tipo 1137 MALPIGHIACEAE: 62 - Peixotoa; 63; 64 e 65 - Byrsonima MELASTOMATACEAE: 66; 67; 68 e 69 MORACEAE: 70 - Brosimum 


\section{Registro Fotogräfifico}

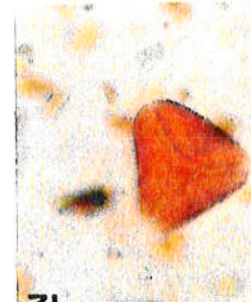

71
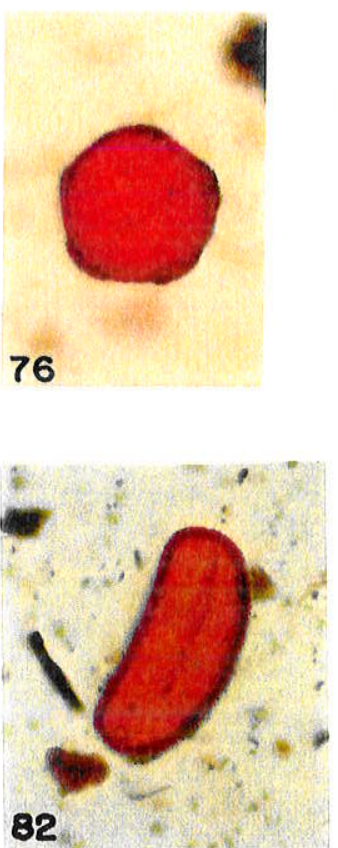

87

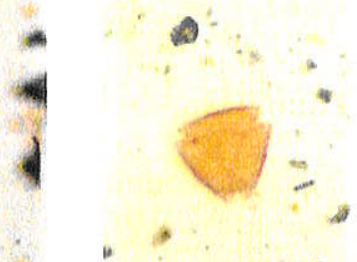

72
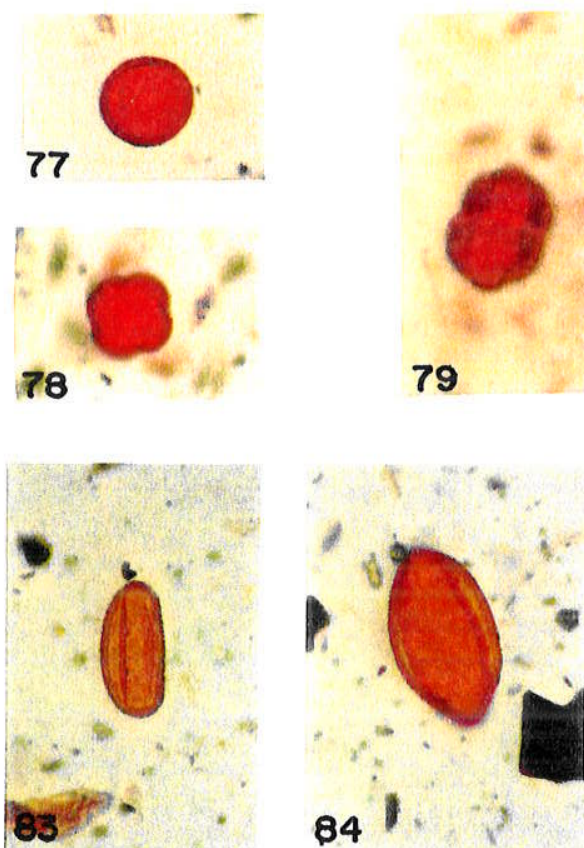

84
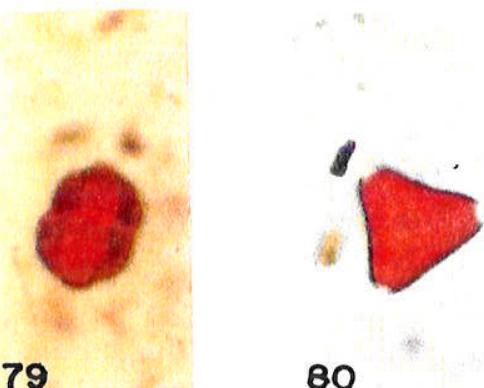

80

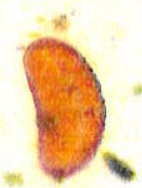

85
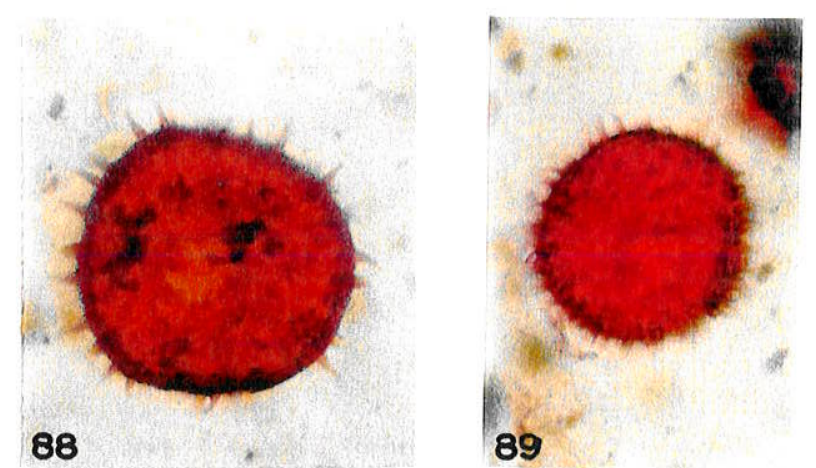
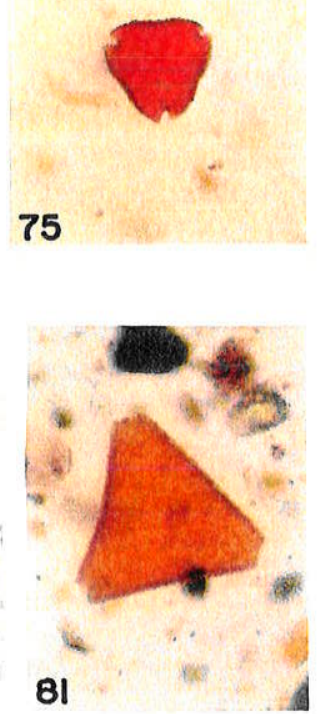

86

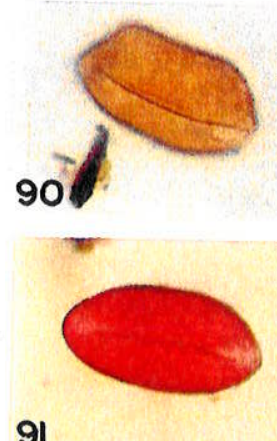

(X 40)

Prancha 5

MYRTACEAE: $71 ; 72 ; 73 ; 74$ e 75

MYRSINACEAE: 77 e 78 - Rapanea

ONAGRACEAE: 76 - Myriophyllum

PALMAE: 87; 88 e 89 -Mauritia; 90 e 91 - Tipo 1199

POLYGALACEAE: 79 - Tipo 1088

PONTEDERIACEAE: 82; 83; 84; 85 e 86

PROTEACEAE: 80 e 81 - Roupala/Euplassa 
Rogistro Fotográfico

92
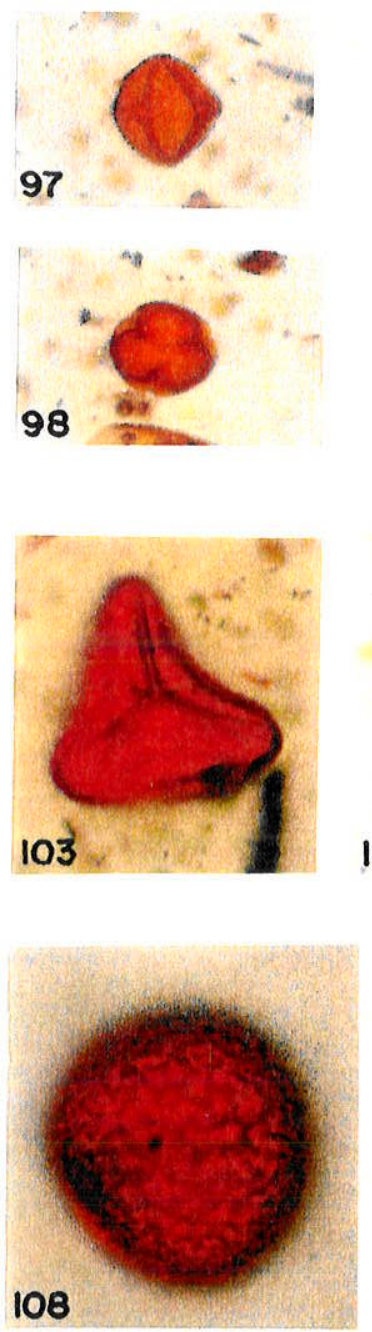

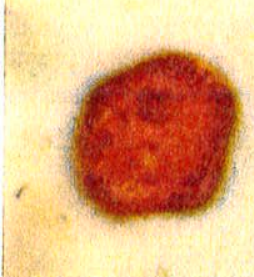

93

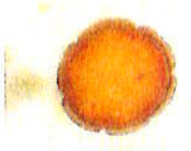

94

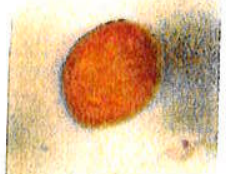

95
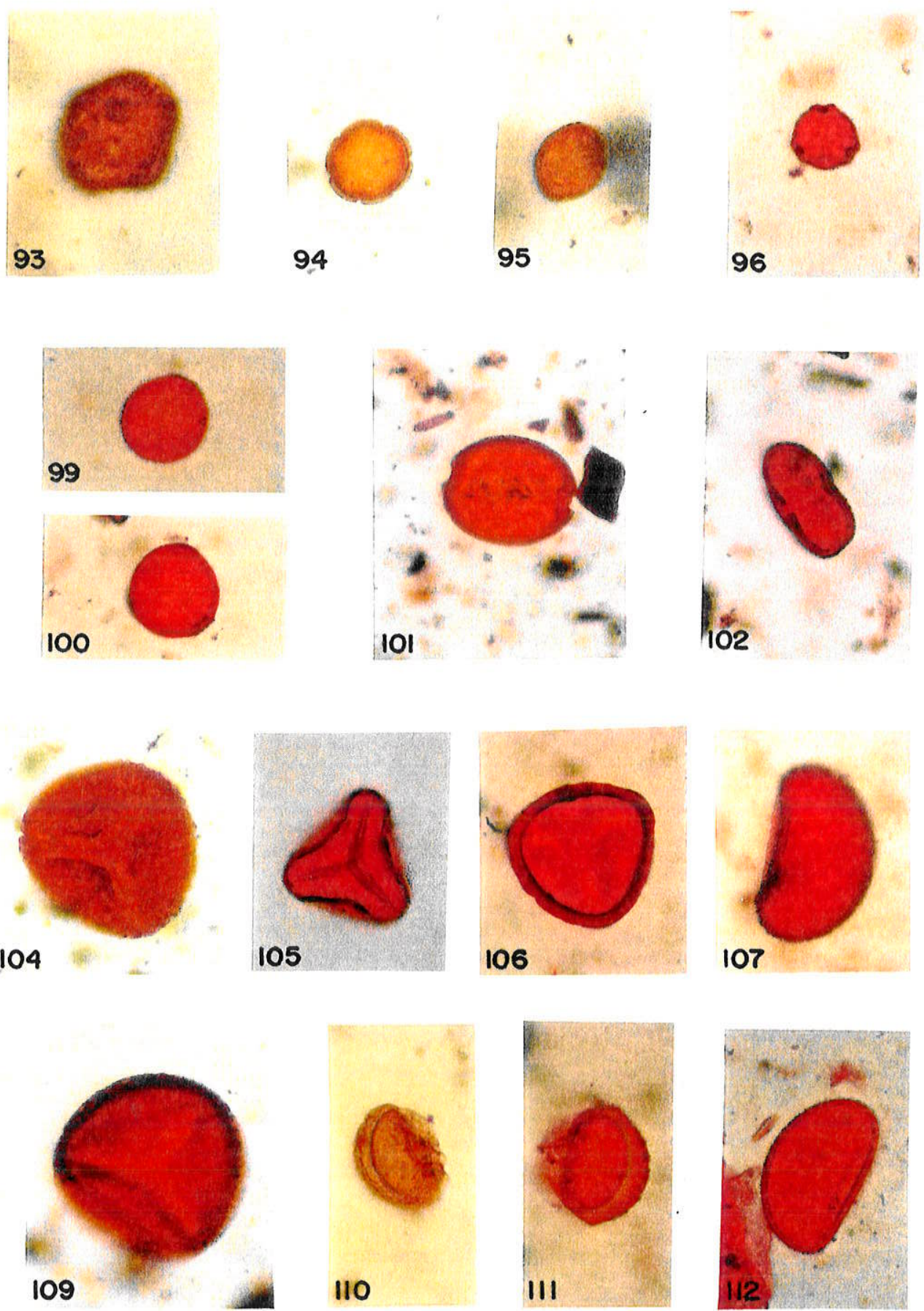

(X 40)

Prancha 6

RUBIACEAE: 92 e 93 - Tipo 1099; 94 e 95 - Borreria

SOLANACEAE: 96 STYRACACEAE: 97 e 98 - Styrax ULMACEAE: 101 - Trema SYMPLOCACEAE: 99 e 100 - Symplocos PTERIDÓFITAS:

ESPOROS TRILETES: 103; 104 e 105 - Outros triletes 106 - Alsophila; 108 e 109 - Lycopodium ESPOROS MONOLETES: 107 e 112 - Outros monoletes 


\section{Registro Fotográfico}
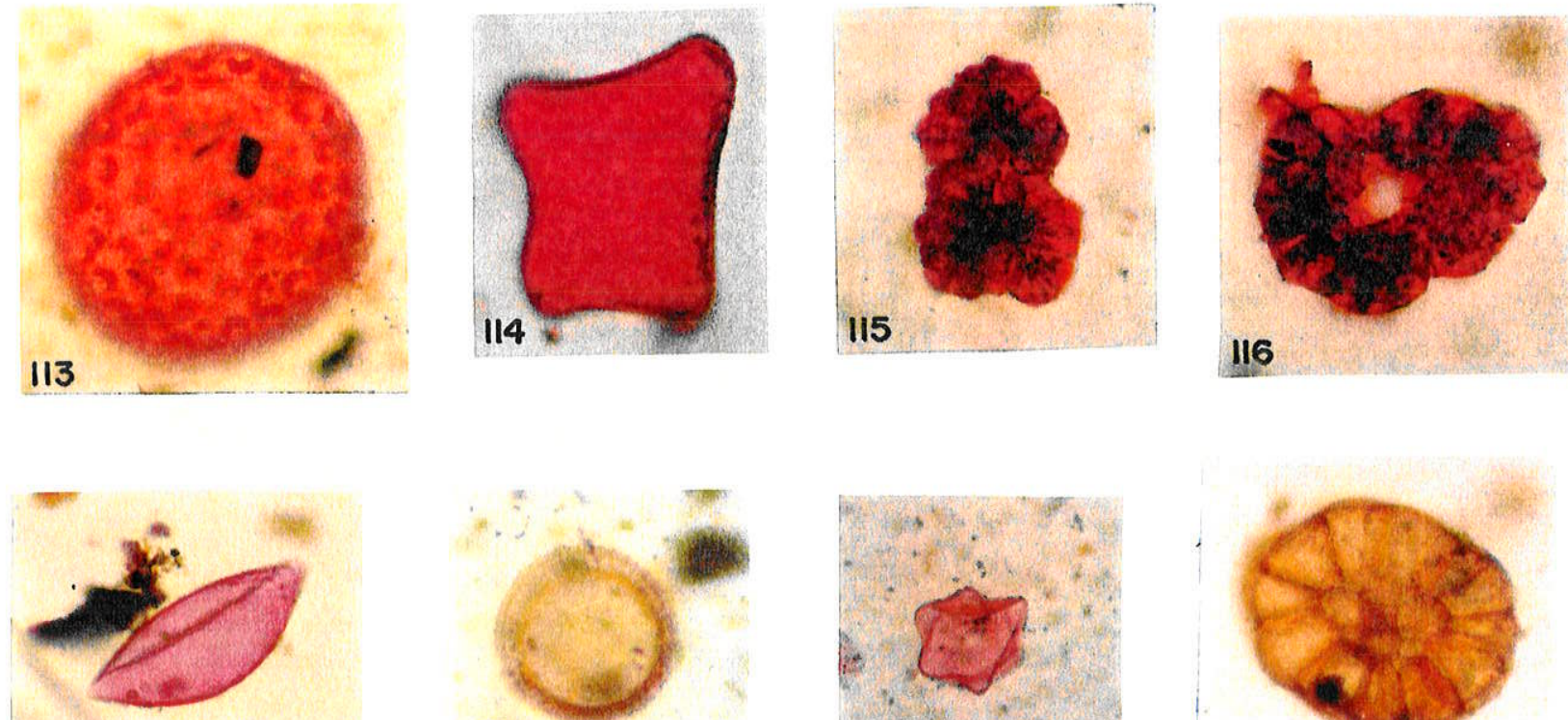

117
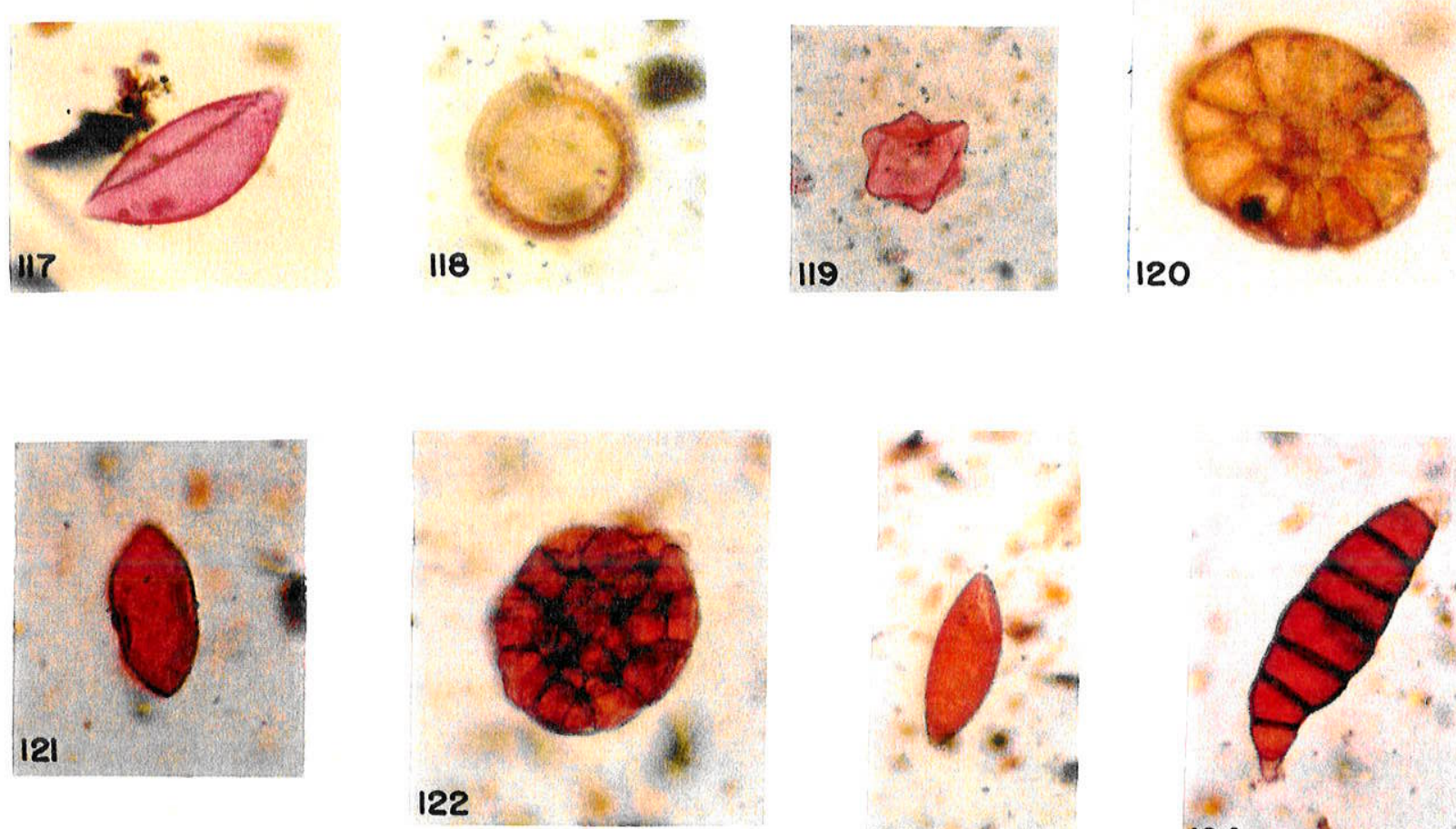

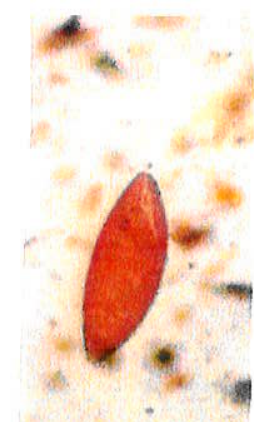

123
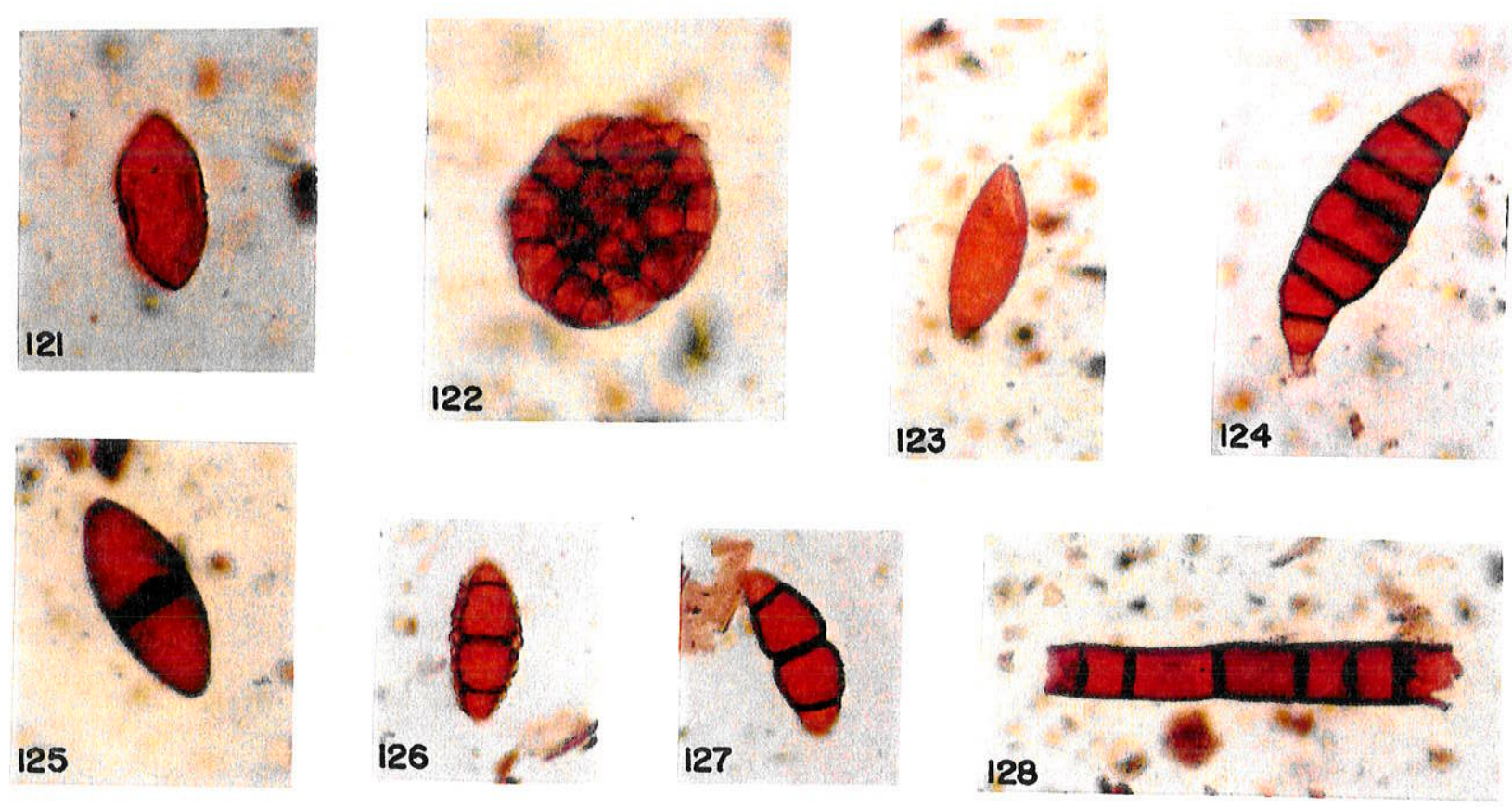

Prancha 7

$(x 40)$

ALGAS:

ZYGNEMATACEAE: 113

Mougeotia - 114; Botryococcus - 115 e 116; Spirogyra - 117; Debarya - 118

Outras Algas: 119; 120

ESPOROS DE FUNGOS: 121; 122; 123; 124; 125; 126; 127; 128 
Registro Fotográficico
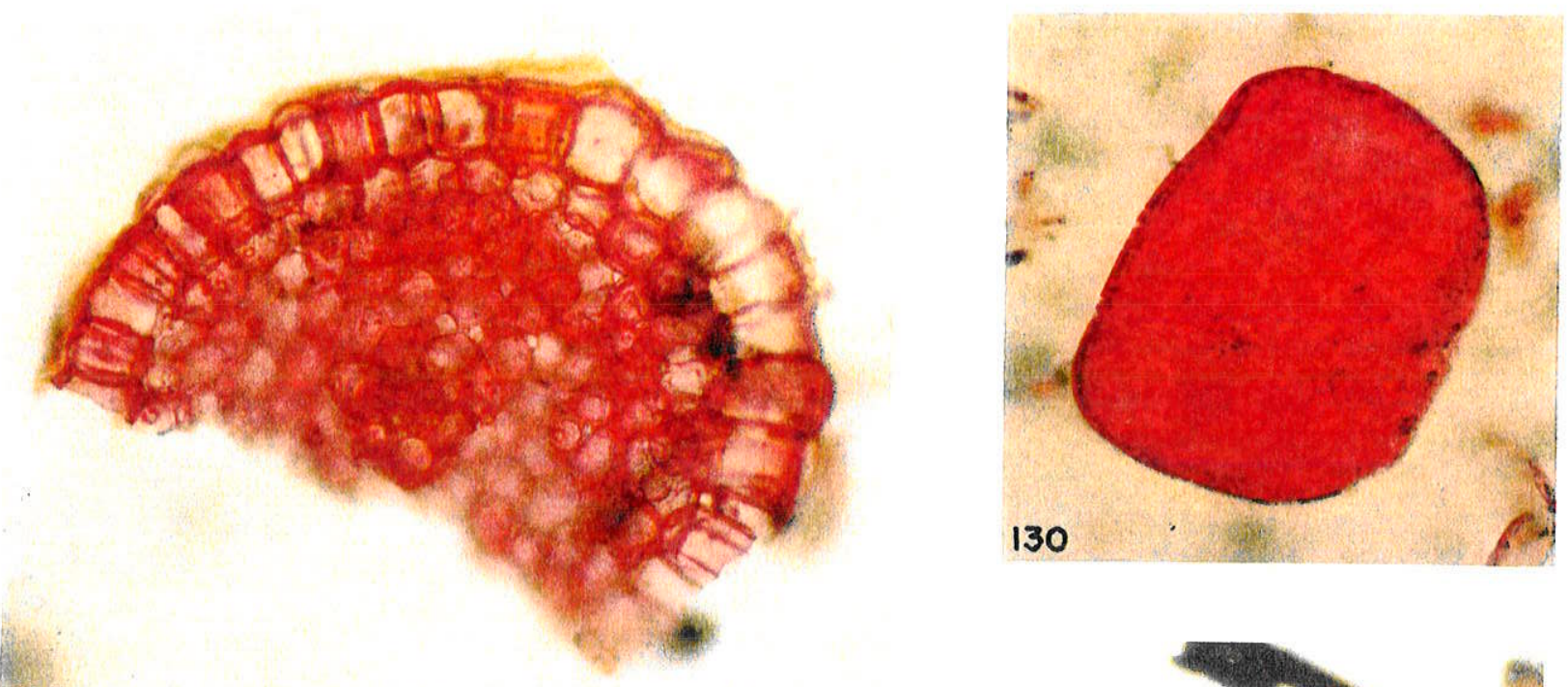

129

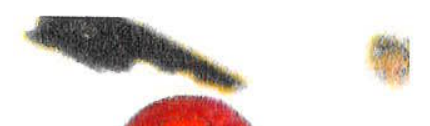

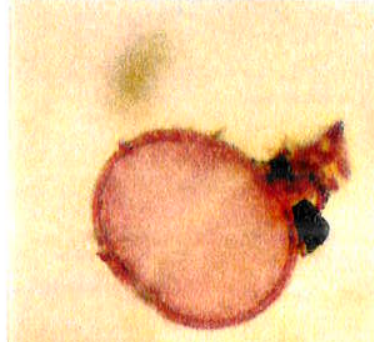

131

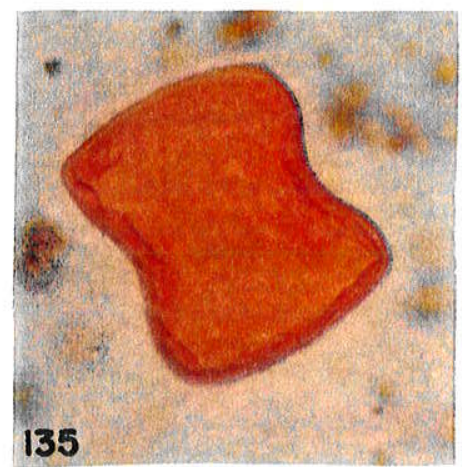

Prancha 8
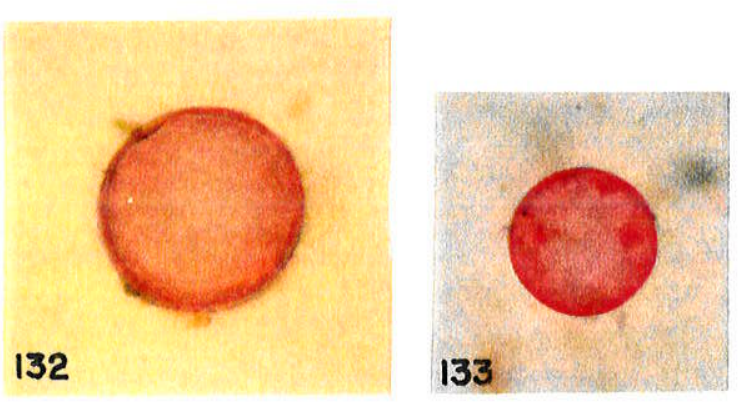

is 6

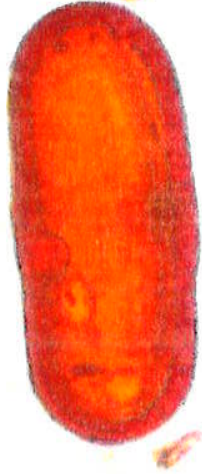

134

OUTROS PALINOMORFOS

Não Identificados: 129; 130; 131; 132; 133; 134; 135; 136; 136

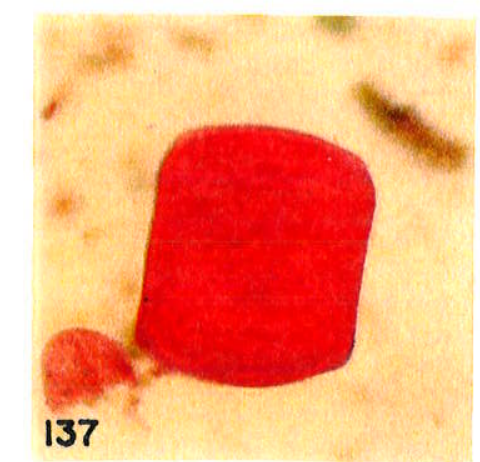

$(X 40)$

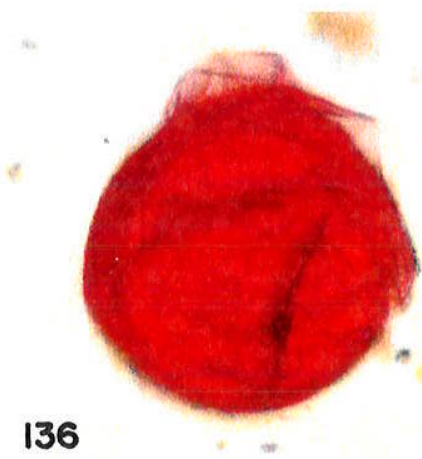


TABELA 3.1: Relação de tipos polínicos do sedimento da Lagoa Bonita, DF

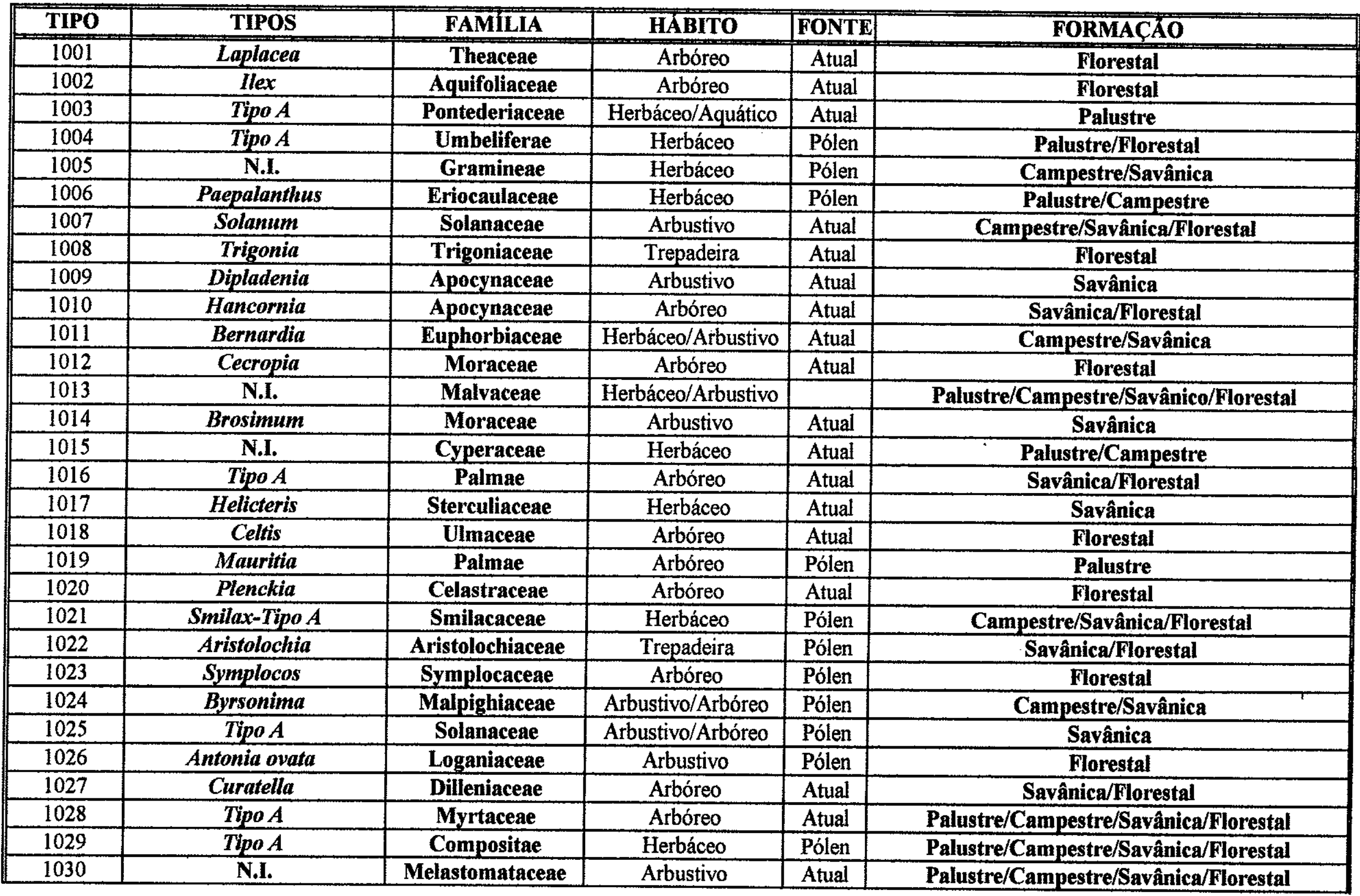
Fontes: Pereira et al. (1990); Ratter (1991); Lorenzi (1992; 1998); Filgueiras \& Pereira (1994); Mendonça et al. (1998); Ribeiro \& Walter (1998)
Onganizaçăo: Maira Barberi 
TABELA 3.1: Relação de tipos polinicos do sedimento da Lagoa Bonita, DF

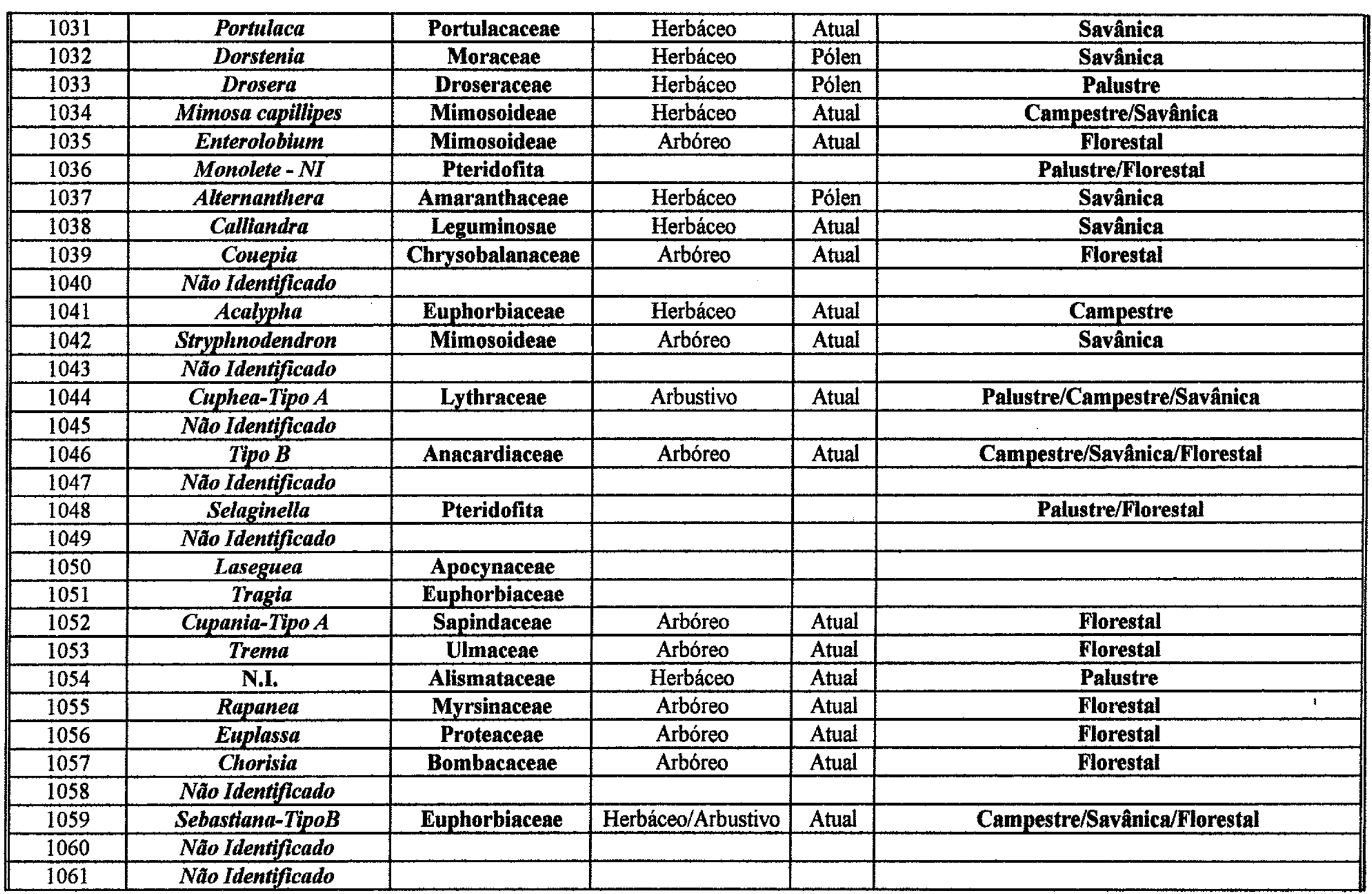

Fontes: Pereira et al. (1990); Ratter (1991); Lorenzi (1992; 1998); Filgueiras \& Pereira (1994); Mendonça et al. (1998); Ribeiro \& Walter (1998) Organizaçăo: Maira Barberi 
TABELA 3.1: Relação de tipos polínicos do sedimento da Lagoa Bonita, DF

\begin{tabular}{|c|c|c|c|c|c|}
\hline 1062 & Salvia & Labiatae & Herbáceo & Atual & Savânica \\
\hline 1063 & Näo Identificado & & & & \\
\hline 1064 & Lafoensia & Lythraceae & Arbóreo & Atual & Savânica/Florestal \\
\hline 1065 & Nâo Identificado & & & & \\
\hline 1066 & Emmotum & Icacinaceae & Arbóreo & Atual & Florestal \\
\hline 1067 & Pelxotoa & Malpighiaceae & Arbustivo & Atual & Savânica \\
\hline 1068 & Sclerolobium & Mimosoideae & Arbóreo & Atual & Savânica \\
\hline 1069 & Tipo B & Umbeliferae & Herbáceo & Atual & Palustre \\
\hline 1070 & Podocarpus & Podocarpaceae & Arbóreo & Atual & Florestal \\
\hline 1071 & Näo Identificado & & & & \\
\hline 1072 & Hedyosmum & Chloranthaceae & Arbustivo & Atual & Florestal \\
\hline 1073 & Ceratosanthes & Cucurbitaceae & & & \\
\hline 1074 & Cupania-Tipo $B$ & Sapindaceae & Arbóreo & Atual & Florestal \\
\hline 1075 & Diospyrus & Ebenaceae & Arbóreo & Atual & Savânica/Florestal \\
\hline 1076 & Lithrae & Anacardiaceae & Arbustivo/Arboreo & Atual & Savânica/Florestal \\
\hline 1077 & Náo Identificado & & & & \\
\hline 1078 & Gomphrena & Amaranthaceae & Herbáceo & Atual & Savấnica \\
\hline 1079 & Copaifera & Caesalpinioideae & Arbóreo & Atual & Florestal \\
\hline 1080 & Tipo $C$ & Rubiaceae & Herbáceo & Atual & Campestre \\
\hline 1081 & Tipo $B$ & Solanaceae & Arbóreo & Atual & Florestal \\
\hline 1082 & Asplenium & Pteridofita & & & Palustre/Florestal \\
\hline 1083 & Pterodon & Faboideae & Arbóreo & Atual & Savânica \\
\hline 1084 & Nao Identificado-Trilete & Pteridofita & & & Palustre/Florestal \\
\hline 1085 & Tipo $A$ & Xyridaceae & Herbáceo/Aquático & Atual & Palustre \\
\hline 1086 & Nöo Identificado & & & & 7 \\
\hline 1087 & Nâo Identificado & & & & \\
\hline 1088 & Bredemeyera-Tipo $A$ & Polygalaceae & Herbáceo & Atual & Campestre \\
\hline 1089 & Lycopodium & Pteridofita & & & Palustre/Florestal \\
\hline 1090 & Hyptis & Labiatae & Herbáceo & Atual & Savânica \\
\hline 1091 & Harpalyce & Leguminosae & Arbustivo & Atual & Savânica \\
\hline 1092 & Arrabidaea & Bignoniaceae & Arbustivo & Atual & Savânica \\
\hline
\end{tabular}

Fontes: Pereira et al. (1990); Ratter (1991); Lorenzi (1992; 1998); Filgueiras \& Pereira (1994); Mendonça et al. (1998); Ribeiro \& Walter (1998) Organizaçăo: Maira Barberi 
TABELA 3.1: Relação de tipos polínicos do sedimento da Lagoa Bonita, DF

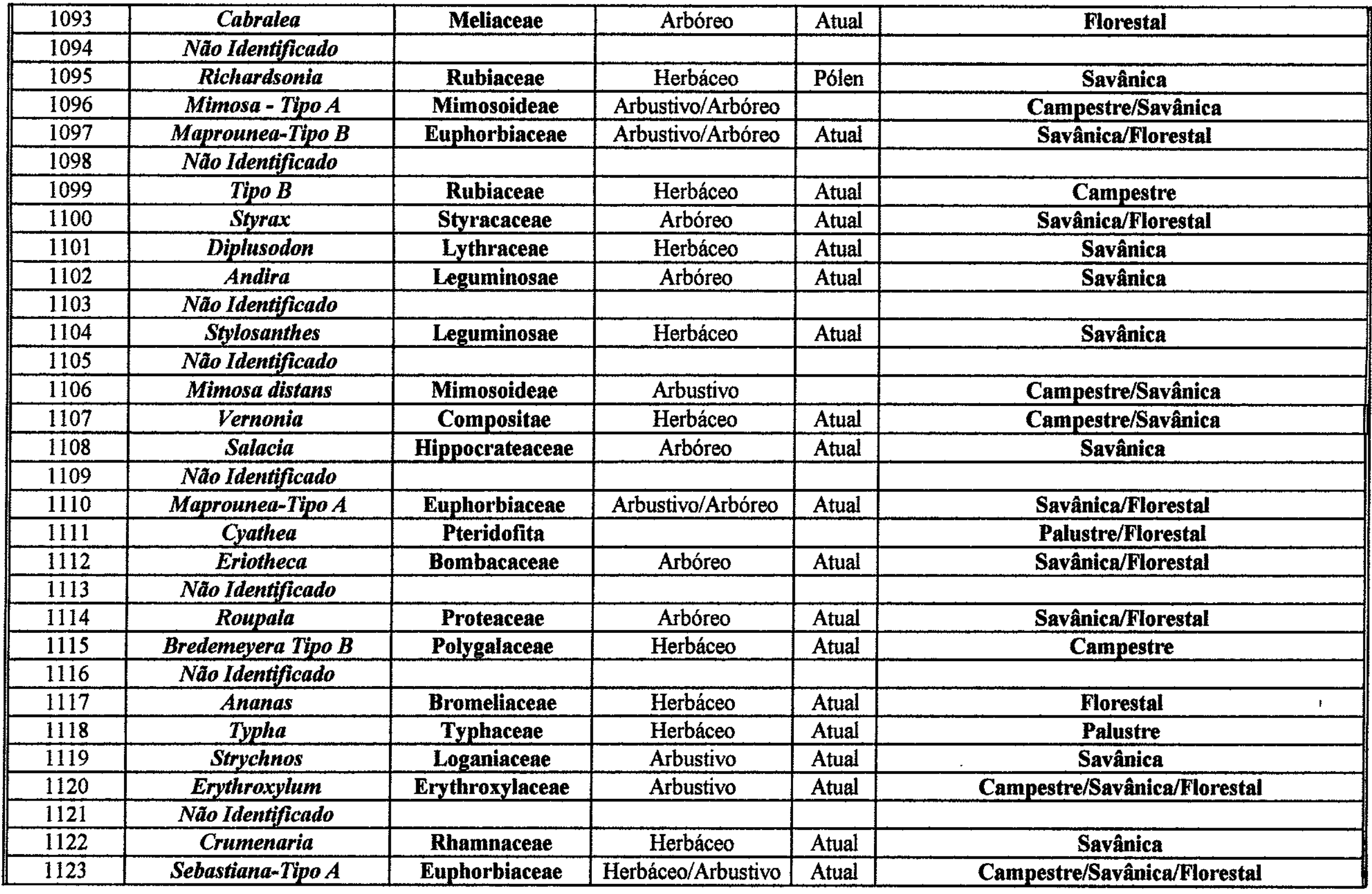

Fontes: Pereira et al. (1990); Ratter (1991); Lorenzi (1992; 1998); Filgueiras \& Pereira (1994); Mendonça et al. (1998); Ribeiro \& Walter (1998) Organizaçăo: Maira Barberi 
TABELA 3.1: Relação de tipos polínicos do sedimento da Lagoa Bonita, DF

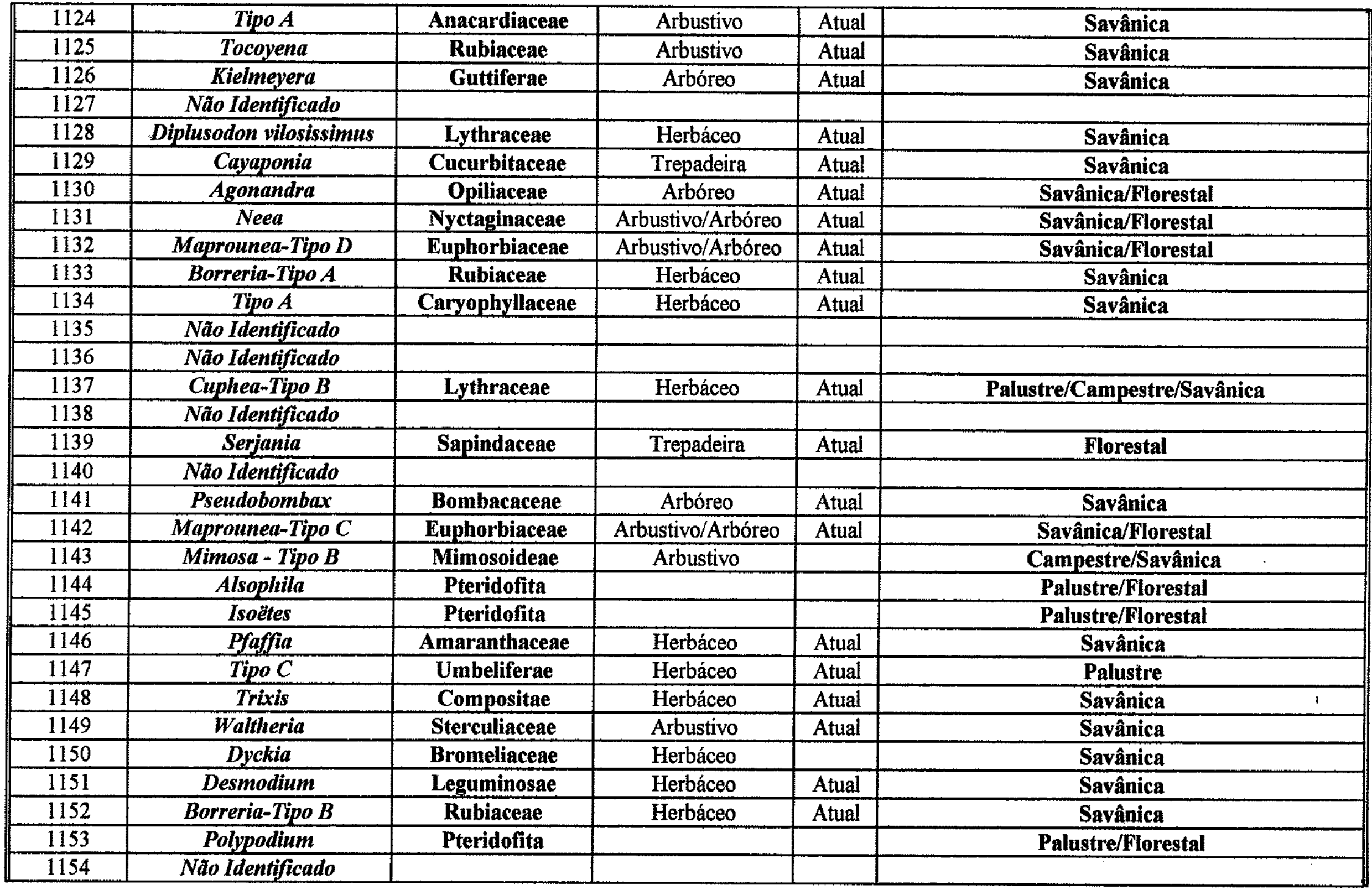

Fontes: Pereira et al. (1990); Ratter (1991); Lorenzi (1992; 1998); Filgueiras \& Pereira (1994); Mendonça et al. (1998); Ribeiro \& Walter (1998) Organizaçấo: Maira Barberi 
TABELA 3.1: Relação de tipos polínicos do sedimento da Lagoa Bonita, DF

\begin{tabular}{|c|c|c|c|c|c|}
\hline 1155 & Nấo Identificado & & & & \\
\hline 1158 & Sapium & Euphorbiaceae & Arbóreo & Atual & Florestal \\
\hline 1160 & Smilax-Tipo B & Smilacaceae & Herbáceo & Pólen & $\begin{array}{c}\text { Savânica } \\
\end{array}$ \\
\hline 1161 & Tppo B & Papilionaceae & & & \\
\hline 1162 & Nấo Identificado & & & & \\
\hline 1165 & Tipo C & Xyridaceae & Herbáceo/Aquático & Atual & Palustre \\
\hline 1166 & Montia & & & & \\
\hline 1167 & Tipo B & Myrtaceae & Arbóreo & Atual & Savânica \\
\hline 1168 & Tipo B & Compositae & Herbáceo & Atual & Savânica \\
\hline 1169 & Não Identificado & & & & \\
\hline 1170 & Cochlospermium & Cochlospermaceae & Herbáceo & Atual & Savânica \\
\hline 1174 & Tipo B & Pontederiaceae & Herbáceo/Aquático & Atual & Savânica \\
\hline 1175 & Didymopanax & Araliaceae & Arbóreo & Atual & Savânica \\
\hline 1176 & Tipo $B$ & Xyridaceae & Herbáceo/Aquático & Atual & Palustre \\
\hline 1177 & Cassia & Leguminosae & & Atual & Savânica \\
\hline 1178 & Tipo C & Pontederiaceae & Herbáceo/Aquático & Atual & Palustre \\
\hline 1179 & Náo Identificado & & & & 1 \\
\hline 1180 & Nâo Identificado & & & & \\
\hline 1181 & Tipo D & Pontederiaceae & Herbáceo/Aquático & Atual & Palustre \\
\hline 1182 & Tipo $C$ & Compositae & Herbáceo & Atual & Savânica \\
\hline 1183 & Myriophyllum & Haloragaceae & Herbáceo/Aquático & Atual & Palustre \\
\hline 1184 & Crotalaria-Tipo B & Leguminosae & Herbáceo & Atual & Savânica \\
\hline 1185 & Tipo $A$ & Rubiaceae & Herbáceo & Atual & Savânica \\
\hline
\end{tabular}

Fontes: Pereira et al. (1990); Ratter (1991); Lorenzi (1992; 1998); Filgueiras \& Pereira (1994); Mendonça et al. (1998); Ribeiro \& Walter (1998) Organizaçăo: Maira Barberi 
TABELA 3.1: Relação de tipos polínicos do sedimento da Lagoa Bonita, DF

continuaçăo

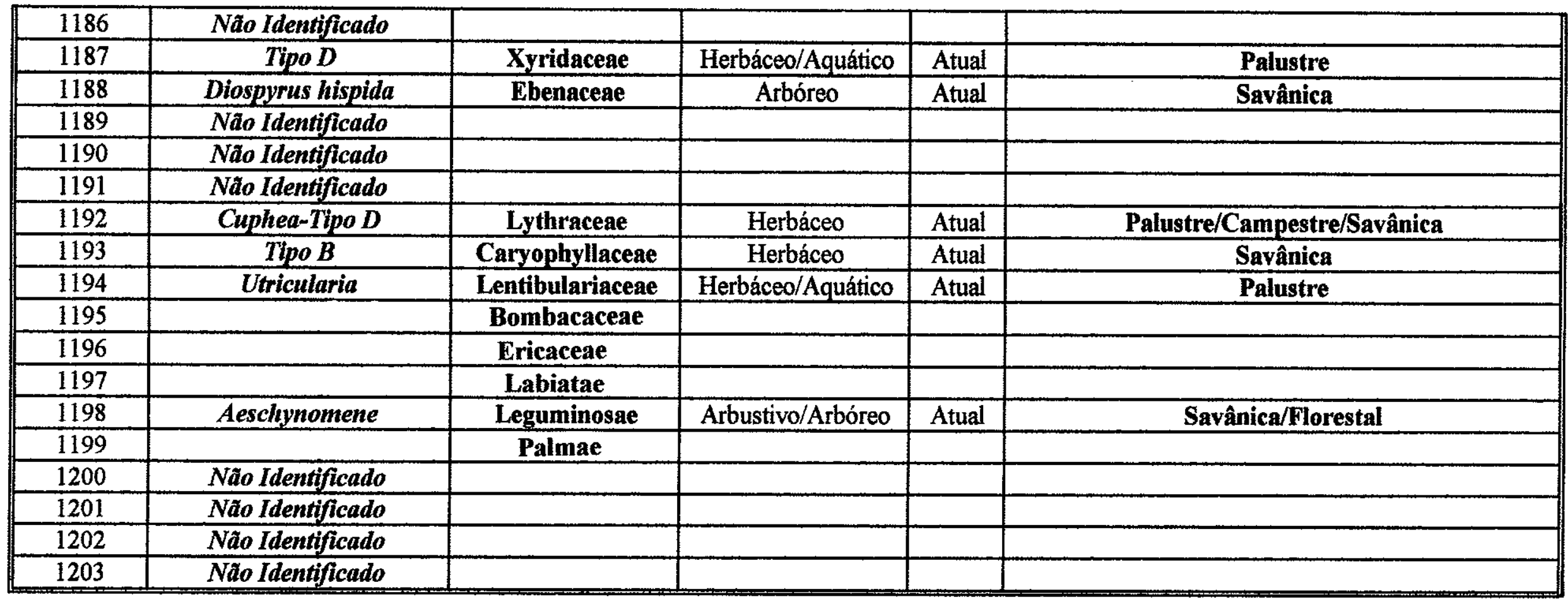

Fontes: Pereira et al. (1990); Ratter (1991); Lorenzi (1992; 1998); Fllgueiras \& Pereira (1994); Mendonça et al. (1998); Ribeiro \& Walter (1998) Organizaçăo: Maira Barberi 
ANEXO 3

TABELA 3.2: Variáveis físicas e biológicas utilizadas no cálculo da concentração dos tipos polínicos

\begin{tabular}{|c|c|c|c|c|c|c|}
\hline NIVEL & $\begin{array}{l}\text { PROF. } \\
\text { (cm) }\end{array}$ & V.S. $\mathrm{cm}^{3}$ & P.S. (g) & P.K. (mg) & K.I. & K.C. \\
\hline & & & & & & \\
\hline 1 & 5,5 & 1 & 1,21 & 0,79 & & 1060 \\
\hline 2 & 10,5 & 1 & 1,20 & 0,66 & $39.958,96$ & 335 \\
\hline 3 & 20,5 & 1 & 1,14 & 0,72 & $43.591,59$ & 629 \\
\hline 4 & 30,5 & 1 & 1,25 & 0,89 & $53.884,05$ & 885 \\
\hline 5 & 40,5 & 1 & 1,13 & 0,64 & $38.748,08$ & 656 \\
\hline 6 & 51,5 & 1 & 1,18 & 0,63 & $38.142,64$ & 611 \\
\hline 7 & 61,5 & 1 & 1,11 & 0,96 & $58.122,12$ & 402 \\
\hline 8 & 70,5 & 1 & 1,19 & 0,78 & $47.224,23$ & 1182 \\
\hline 9 & 80,5 & 1 & 1,28 & 0,74 & $44.802,47$ & 469 \\
\hline 10 & 90,5 & 2 & 3,19 & 0,90 & $54.489,49$ & 904 \\
\hline 11 & 101,5 & 1 & 1,67 & 0,91 & $55.094,93$ & 895 \\
\hline 12 & 110,5 & 1 & 1,81 & 0,74 & $44.802,47$ & 501 \\
\hline 13 & 120,5 & 1 & 1,76 & 0,68 & $41.169,84$ & 360 \\
\hline 14 & 131,5 & 1 & 1,78 & 0,54 & $32.693,70$ & 245 \\
\hline 15 & 140,5 & 1 & 1,86 & 0,98 & $59.333,00$ & 305 \\
\hline 16 & 150,5 & 1 & 1,84 & 0,53 & $32.088,26$ & 126 \\
\hline 17 & 160,5 & 1 & 1,81 & 0,79 & $47.829,67$ & 142 \\
\hline 18 & 170,5 & 1 & 1,67 & 0,73 & $44.197,03$ & 109 \\
\hline 19 & 180,5 & 1 & 1,65 & 0,62 & $37.537,21$ & 110 \\
\hline 20 & 190,5 & 1 & 1,66 & 0,64 & $38.748,08$ & 140 \\
\hline 21 & 201,5 & 1 & 1,68 & 0,61 & $36.931,77$ & 209 \\
\hline 22 & 210,5 & 1 & 1,71 & 0,70 & $42.380,72$ & 201 \\
\hline 23 & 220,5 & 1 & 1,68 & 0,80 & $48.435,10$ & 222 \\
\hline 24 & 230,5 & 1 & 1,59 & 0,80 & $48.435,10$ & 224 \\
\hline 25 & 240,5 & 1 & 1,86 & 0,94 & $56.911,25$ & 196 \\
\hline 26 & 250,5 & 1 & 1,71 & 0,85 & $51.462,30$ & 356 \\
\hline 27 & 260,5 & 1 & 1,8 & 0,9 & $54.489,49$ & 335 \\
\hline 28 & 271,5 & 1 & 1,59 & 1,05 & $63.571,07$ & 191 \\
\hline 29 & 280,5 & 1 & 1,95 & 0,55 & $33.299,13$ & 256 \\
\hline 30 & 290,5 & 1 & 1,91 & 0,68 & $41.169,84$ & 87 \\
\hline 31 & 314,5 & 1 & 1,82 & 0,53 & $32.088,26$ & 96 \\
\hline 32 & 345,5 & 1 & 1,72 & 0,88 & $53.278,61$ & 87 \\
\hline
\end{tabular}


TABELA 3.3: Qualificação e quantificação dos tipos polínicos da Lagoa Bonita, DF

\begin{tabular}{|c|c|c|c|c|c|c|c|c|c|c|c|c|c|c|c|}
\hline \multirow{2}{*}{ NIVEL. } & \multirow{2}{*}{$\begin{array}{c}\text { PROF. } \\
(\mathrm{cm})\end{array}$} & \multirow{2}{*}{$\boldsymbol{B}$} & \multirow{2}{*}{ NTO } & \multicolumn{3}{|c|}{ Tipo Trema $=1053$} & \multicolumn{3}{|c|}{ Tipo Symplocos - 1023} & \multicolumn{3}{|c|}{ Tipo Rapanea - 1055} & \multicolumn{3}{|c|}{ Tipo Salacia - 1108} \\
\hline & & & & No Gráos & $\mathbf{P}(\%)$ & C & No Gráos & $P(\%)$ & $\mathbf{C}$ & $N^{\circ}$ Grános & $P(\%)$ & $\mathbf{C}$ & $N^{\circ}$ Cräos & $\mathrm{P}(\%)$ & $\mathbf{C}$ \\
\hline \multicolumn{16}{|l|}{ S1 } \\
\hline 1 & 5,5 & 45,1223 & 922 & 35 & 3,8 & 1579,3 & 40 & 4,3 & 1804,9 & 6 & 0,7 & 270,7 & 0 & 0,0 & 0,0 \\
\hline 2 & 10,5 & 119,28 & 778 & 10 & 1,3 & 1192,8 & 34 & 4,4 & 4055,5 & 3 & 0,4 & 357,8 & 0 & 0,0 & 0,0 \\
\hline 3 & 20,5 & 69,303 & 877 & 17 & 1,9 & 1178,2 & 22 & 2,5 & 1524,7 & 4 & 0,5 & 277,2 & 0 & 0,0 & 0,0 \\
\hline 4 & 30,5 & 60,8859 & 962 & 10 & 1,0 & 608,9 & 15 & 1,6 & 913,3 & 4 & 0,4 & 243,5 & 0 & 0,0 & 0,0 \\
\hline 5 & 40,5 & 59,0672 & 903 & 12 & 1,3 & 708,8 & 14 & 1,6 & 826,9 & 2 & 0,2 & 118,1 & 0 & 0,0 & 0,0 \\
\hline 6 & 51,5 & 62,4266 & 930 & 12 & 1,3 & 749,1 & 15 & 1,6 & 936,4 & 1 & 0,1 & 62,4 & 0 & 0,0 & 0,0 \\
\hline 7 & 61,5 & 144,582 & 520 & 12 & 2,3 & 1735,0 & 8 & 1,5 & 1156,7 & 1 & 0,2 & 144,6 & 0 & 0,0 & 0,0 \\
\hline 8 & 70,5 & 39,9528 & 744 & 21 & 2,8 & 839,0 & 15 & 2,0 & 599,3 & 6 & 0,8 & 239,7 & 0 & 0,0 & 0,0 \\
\hline 9 & 80,5 & 95,5277 & 871 & 12 & 1,4 & 1146,3 & 6 & 0,7 & 573,2 & 4 & 0,5 & 382,1 & 0 & 0,0 & 0,0 \\
\hline 10 & 90,5 & 30,138 & 341 & 7 & 2,1 & 211,0 & 5 & 1,5 & 150,7 & 0 & 0,0 & 0,0 & 0 & 0,0 & 0,0 \\
\hline 11 & 101,5 & 61,5586 & 702 & 15 & 2,1 & 923,4 & 32 & 4,6 & 1969,9 & 14 & 2,0 & 861,8 & 0 & 0,0 & 0,0 \\
\hline 12 & 110,5 & 89,4261 & 537 & 19 & 3,5 & 1699,1 & 19 & 3,5 & 1699,1 & 20 & 3,7 & 1788,5 & 0 & 0,0 & 0,0 \\
\hline 13 & 120,5 & 114,361 & 510 & 16 & 3,1 & 1829,8 & 6 & 1,2 & 686,2 & 16 & 3,1 & 1829,8 & 0 & 0,0 & 0,0 \\
\hline 14 & 131,5 & 133,444 & 488 & 4 & 0,8 & 533,8 & 0 & 0,0 & 0,0 & 22 & 4,5 & 2935,8 & 0 & 0,0 & 0,0 \\
\hline 15 & 140,5 & 194,534 & 541 & 9 & 1,7 & 1750,8 & 5 & 0,9 & 972,7 & 10 & 1,8 & 1945,3 & 0 & 0,0 & 0,0 \\
\hline 16 & 150,5 & 254,669 & 858 & 1 & 0,1 & 254,7 & 1 & 0,1 & 254,7 & 19 & 2,2 & 4838,7 & 0 & 0,0 & 0,0 \\
\hline 17 & 160,5 & 336,829 & 947 & 0 & 0,0 & 0,0 & 3 & 0,3 & 1010,5 & 11 & 1,2 & 3705,1 & 0 & 0,0 & 0,0 \\
\hline 18 & 170,5 & 405,477 & 1000 & 4 & 0,4 & 1621,9 & 8 & 0,8 & 3243,8 & 14 & 1,4 & 5676,7 & 0 & 0,0 & 0,0 \\
\hline 19 & 180,5 & 341,247 & 1119 & 4 & 0,4 & 1365,0 & 7 & 0,6 & 2388,7 & 14 & 1,3 & 4777,5 & 0 & 0,0 & 0,0 \\
\hline 20 & 190,5 & 276,772 & 1239 & 2 & 0,2 & 553,5 & 4 & 0,3 & 1107,1 & 15 & 1,2 & 4151,6 & 0 & 0,0 & 0,0 \\
\hline 21 & 201,5 & 176,707 & 829 & 2 & 0,2 & 353,4 & 13 & 1,6 & 2297,2 & 14 & 1,7 & 2473,9 & 0 & 0,0 & 0,0 \\
\hline 22 & 210,5 & 210,849 & 859 & 0 & 0,0 & 0,0 & 6 & 0,7 & 1265,1 & 14 & 1,6 & 2951,9 & 3 & 0,3 & 632,5 \\
\hline 23 & 220,5 & 218,176 & 765 & 3 & 0,4 & 654,5 & 32 & 4,2 & 6981,6 & 5 & 0,7 & 1090,9 & 2 & 0,3 & 436,4 \\
\hline 24 & 230,5 & 216,228 & 715 & 13 & 1,8 & 2811,0 & 34 & 4,8 & 7351,8 & 1 & 0,1 & 216,2 & 0 & 0,0 & 0,0 \\
\hline 25 & 240,5 & 290,364 & 670 & 11 & 1,6 & 3194,0 & 31 & 4,6 & 9001,3 & 2 & 0,3 & 580,7 & 3 & 0,4 & 871,1 \\
\hline 26 & 250,5 & 144,557 & 741 & 10 & 1,3 & 1445,6 & 25 & 3,4 & 3613,9 & 1 & 0,1 & 144,6 & 1 & 0,1 & 144,6 \\
\hline 27 & 260,5 & 162,655 & 687 & 9 & 1,3 & 1463,9 & 31 & 4,5 & 5042,3 & 2 & 0,3 & 325,3 & 6 & 0,9 & 975,9 \\
\hline 28 & 271,5 & 332,833 & 761 & 10 & 1,3 & 3328,3 & 32 & 4,2 & 10650,7 & 3 & 0,4 & 998,5 & 4 & 0,5 & 1331,3 \\
\hline 29 & 280,5 & 130,075 & 456 & 5 & 1,1 & 650,4 & 16 & 3,5 & 2081,2 & 1 & 0,2 & 130,1 & 0 & 0,0 & 0,0 \\
\hline 30 & 290,5 & 473,217 & 0,0 & 0,0 & 0,0 & 0,0 & 0,0 & 0,0 & 0,0 & 0,0 & 0,0 & 0,0 & 0,0 & 0,0 & 0,0 \\
\hline 31 & 314,5 & 334,253 & 0,0 & 0,0 & 0,0 & 0,0 & 0,0 & 0,0 & 0,0 & 0,0 & 0,0 & 0,0 & 0,0 & 0,0 & 0,0 \\
\hline 32 & 345,5 & 612,398 & 0,0 & 0,0 & 0,0 & 0,0 & 0,0 & 0,0 & 0,0 & 0,0 & 0,0 & 0,0 & 0,0 & 0,0 & 0,0 \\
\hline
\end{tabular}


TABELA 3.3: Qualificação e quantificação dos tipos polínicos da Lagoa Bonita, DF

continuação

\begin{tabular}{|c|c|c|c|c|c|c|c|c|c|c|c|c|c|c|c|}
\hline \multirow{2}{*}{ NIVEL } & \multirow{2}{*}{$\begin{array}{l}\text { PROF. } \\
(\mathrm{cm})\end{array}$} & \multirow{2}{*}{ B } & \multirow{2}{*}{ NTO } & \multicolumn{3}{|c|}{ Tipo Hedyosmum - 1072} & \multicolumn{3}{|c|}{ Tipo llex - 1002} & \multicolumn{3}{|c|}{ Tioo Cupania - 1052} & \multicolumn{3}{|c|}{ Tipo Copalfera - 1079} \\
\hline & & & & No Grắos & $P(\%)$ & C & Nº Grăos & $\mathbf{P ( \% )}$ & C & No Grá̃os & $P(\%)$ & C & No Grăos & $\mathrm{P}(\%)$ & C \\
\hline \multicolumn{16}{|l|}{ \$1 } \\
\hline 1 & 5,5 & 45,1223 & 922 & 3 & 0,3 & 135,4 & 2 & 0,2 & 90,2 & 0 & 0,0 & 0,0 & 4 & 0,4 & 180,5 \\
\hline 2 & 10,5 & 119,28 & 778 & 2 & 0,3 & 238,6 & 1 & 0,1 & 119,3 & 4 & 0,5 & 477,1 & 2 & 0,3 & 238,6 \\
\hline 3 & 20,5 & 69,303 & 877 & $\overline{3}$ & 0,3 & 207,9 & 1 & 0,1 & 69,3 & 1 & 0,1 & 69,3 & 4 & 0,5 & 277,2 \\
\hline 4 & 30,5 & 60,8859 & 962 & 7 & 0,7 & 426,2 & $\overline{1}$ & 0,1 & 60,8 & 2 & 0,2 & 121,8 & 6 & 0,6 & 365,3 \\
\hline 5 & 40,5 & 59,0672 & 903 & 1 & 0,1 & 59,1 & 3 & 0,3 & 177,2 & 0 & 0,0 & 0,0 & 6 & 0,7 & 354,4 \\
\hline 6 & 51,5 & 62,4266 & 930 & 2 & 0,2 & 124,9 & 1 & 0,1 & 62,4 & 2 & 0,2 & 124,9 & 4 & 0,4 & 249,7 \\
\hline 7 & 61,5 & 144,582 & 520 & 1 & 0,2 & 144,6 & 0 & 0,0 & 0,0 & 0 & 0,0 & 0,0 & 1 & 0,2 & 144,6 \\
\hline 8 & 70,5 & 39,9528 & 744 & 2 & 0,3 & 79,9 & 0 & 0,0 & 0,0 & 1 & 0,1 & 40,0 & 1 & 0,1 & 40,0 \\
\hline 9 & 80,5 & 95,5277 & 871 & 0 & 0,0 & 0,0 & 2 & 0,2 & 191,1 & 1 & 0,1 & 95,5 & 4 & 0,5 & 382,1 \\
\hline 10 & 90,5 & 30,138 & 341 & 0 & 0,0 & 0,0 & 2 & 0,6 & 60,3 & 0 & 0,0 & 0,0 & 0 & 0,0 & 0,0 \\
\hline 11 & 101,5 & 61,5586 & 702 & 0 & 0,0 & 0,0 & 2 & 0,3 & 123,1 & 2 & 0,3 & 123,1 & 5 & 0,7 & 307,8 \\
\hline 12 & 110,5 & 89,4261 & 537 & 7 & 1,3 & 626,0 & 1 & 0,2 & 89,4 & 1 & 0,2 & 89,4 & 2 & 0,4 & 178,9 \\
\hline 13 & 120,5 & 114,361 & 510 & 10 & 2,0 & 1143,6 & 1 & 0,2 & 114,4 & 0 & 0,0 & 0,0 & 0 & 0,0 & 0,0 \\
\hline 14 & 131,5 & 133,444 & 488 & 4 & 0,8 & 533,8 & 1 & 0,2 & 133,4 & 0 & 0,0 & 0,0 & 0 & 0,0 & 0,0 \\
\hline 15 & 140,5 & 194,534 & 541 & 12 & 2,2 & 2334,4 & 5 & 0,9 & 972,7 & 0 & 0,0 & 0,0 & 1 & 0,2 & 194,5 \\
\hline 16 & 150,5 & 254,669 & 858 & 17 & 2,0 & 4329,4 & $\overline{6}$ & 0,7 & 1528,0 & 0 & 0,0 & 0,0 & 0 & 0,0 & 0,0 \\
\hline 17 & 160,5 & 336,829 & 947 & 18 & 1,9 & 6062,9 & 1 & 0,1 & 336,8 & 3 & 0,3 & 1010,5 & 0 & 0,0 & 0,0 \\
\hline 18 & 170,5 & 405,477 & 1000 & 31 & 3,1 & 12569,8 & 1 & 0,1 & 405,5 & 0 & 0,0 & 0,0 & 2 & 0,2 & 811,0 \\
\hline 19 & 180,5 & 341,247 & 1119 & 33 & 2,9 & 11261,2 & 3 & 0,3 & 1023,7 & 3 & 0,3 & 1023,7 & 0 & 0,0 & 0,0 \\
\hline 20 & 190,5 & 276,772 & 1239 & 37 & 3,0 & 10240,6 & 9 & 0,7 & 2490,9 & 1 & 0,1 & 276,8 & 0 & 0,0 & 0,0 \\
\hline 21 & 201,5 & 176,707 & 829 & 9 & 1,1 & 1590,4 & 3 & 0,4 & 530,1 & 1 & 0,1 & 176,7 & 0 & 0,0 & 0,0 \\
\hline 22 & 210,5 & 210,849 & 859 & 11 & 1,3 & 2319,3 & 4 & 0,5 & 843,4 & 0 & 0,0 & 0,0 & 0 & 0,0 & 0,0 \\
\hline 23 & 220,5 & 218,176 & 765 & 4 & 0,5 & 872,7 & 4 & 0,5 & 872,7 & 2 & 0,3 & 436,4 & 0 & 0,0 & 0,0 \\
\hline 24 & 230,5 & 216,228 & 715 & 11 & 1,5 & 2378,5 & 6 & 0,8 & 1297,4 & 4 & 0,6 & 864,9 & 0 & 0,0 & 0,0 \\
\hline 25 & 240,5 & 290,364 & 670 & 7 & 1,0 & 2032,5 & 6 & 0,9 & 1742,2 & 3 & 0,4 & 871,1 & 1 & 0,1 & 290,4 \\
\hline 26 & 250,5 & 144,557 & 741 & 12 & 1,6 & 1734,7 & 6 & 0,8 & 867,3 & 0 & 0,0 & 0,0 & 2 & 0,3 & 289,1 \\
\hline 27 & 260,5 & 162,655 & 687 & 17 & 2,5 & 2765,1 & 7 & 1,0 & 1138,6 & 0 & 0,0 & 0,0 & 0 & 0,0 & 0,0 \\
\hline 28 & 271,5 & 332,833 & 761 & 25 & 3,3 & 8320,8 & 5 & 0,7 & 1664,2 & 4 & 0,5 & 1331,3 & 0 & 0,0 & 0,0 \\
\hline 29 & 280,5 & 130,075 & 456 & 17 & 3,7 & 2211,3 & 3 & 0,7 & 390,2 & 0 & 0,0 & 0,0 & 1 & 0,2 & 130,1 \\
\hline 30 & 290,5 & 473,217 & 0,0 & 0,0 & 0,0 & 0,0 & 0,0 & 0,0 & 0,0 & 0,0 & 0,0 & 0,0 & 0,0 & 0,0 & 0,0 \\
\hline 31 & 314,5 & 334,253 & 0,0 & 0,0 & 0,0 & 0,0 & 0,0 & 0,0 & 0,0 & 0,0 & 0,0 & 0,0 & 0,0 & 0,0 & 0,0 \\
\hline 32 & 345,5 & 612,398 & 0,0 & 0,0 & 0,0 & 0,0 & 0,0 & 0,0 & 0,0 & 0,0 & 0,0 & 0,0 & 0,0 & 0,0 & 0,0 \\
\hline
\end{tabular}


TABELA 3.3: Qualificação e quantificaçăo dos tipos polínicos da Lagoa Bonita, DF

continuação

\begin{tabular}{|c|c|c|c|c|c|c|c|c|c|c|c|c|c|c|c|}
\hline \multirow{2}{*}{ NIVEL } & \multirow{2}{*}{$\begin{array}{l}\text { PROF. } \\
(\mathbf{c m})\end{array}$} & \multirow{2}{*}{ B } & \multirow{2}{*}{ NTE } & \multicolumn{3}{|c|}{ Tipo Antonia ovata - 1026} & \multicolumn{3}{|c|}{ Tipo Emmotum - 1066} & \multicolumn{3}{|c|}{ Tipo Styrax - 1100} & \multicolumn{3}{|c|}{ Tipo Dyospirus - 1075} \\
\hline & & & & No Grăos & $P(\%)$ & C & $\mathrm{N}^{\circ}$ Crăos & $P(\%)$ & C & $N^{\circ}$ Grãos & $P(\%)$ & $C$ & No Grấos & $P(\%)$ & $c$ \\
\hline s1 & & & & & & & & & & & & & & & \\
\hline 1 & 5,5 & 45,1223 & 922 & 8 & 0,9 & 361,0 & 4 & 0,4 & 180,5 & 0 & 0,0 & 0,0 & 1 & 0,1 & 45,1 \\
\hline 2 & 10,5 & 119,28 & 778 & 16 & 2,1 & 1908,5 & 3 & 0,4 & 357,8 & 0 & 0,0 & 0,0 & 1 & 0,1 & 119,3 \\
\hline 3 & 20,5 & 69,303 & 877 & 6 & 0,7 & 415,8 & 3 & $c, 3$ & 207,9 & 1 & 0,1 & 69,3 & 0 & 0,0 & 0,0 \\
\hline 4 & 30,5 & 60,8859 & 962 & 13 & 1,4 & 791,5 & 0 & 0,0 & 0,0 & 0 & 0,0 & 0,0 & 0 & 0,0 & 0,0 \\
\hline 5 & 40,5 & 59,0672 & 903 & 14 & 1,6 & 826,9 & 2 & 0,2 & 118,1 & 8 & 0,9 & 472,5 & 0 & 0,0 & 0,0 \\
\hline 6 & 51,5 & 62,4266 & 930 & 5 & 0,5 & 312,1 & 0 & 0,0 & 0,0 & 0 & 0,0 & 0,0 & 0 & 0,0 & 0,0 \\
\hline 7 & 61,5 & 144,582 & 520 & 2 & 0,4 & 289,2 & 2 & 0,4 & 289,2 & 1 & 0,2 & 144,6 & 0 & 0,0 & 0,0 \\
\hline 8 & 70,5 & 39,9528 & 744 & 5 & 0,7 & 199,8 & 2 & 0,3 & 79,9 & 0 & 0,0 & 0,0 & 0 & 0,0 & 0,0 \\
\hline 9 & 80,5 & 95,5277 & 871 & 11 & 1,3 & 1050,8 & 7 & 0,8 & 668,7 & 0 & 0,0 & 0,0 & 0 & 0,0 & 0,0 \\
\hline 10 & 90,5 & 30,138 & 341 & 0 & 0,0 & 0,0 & 0 & 0,0 & 0,0 & 0 & 0,0 & 0,0 & 1 & 0,3 & 30,1 \\
\hline 11 & 101,5 & 61,5586 & 702 & 4 & 0,6 & 246,2 & 0 & 0,0 & 0,0 & 1 & 0,1 & 61,6 & 0 & 0,0 & 0,0 \\
\hline 12 & 110,5 & 89,4261 & 537 & 15 & 2,8 & 1341,4 & 0 & 0,0 & 0,0 & 0 & 0,0 & 0,0 & 1 & 0,2 & 89,4 \\
\hline 13 & 120,5 & 114,361 & 510 & 11 & 2,2 & 1258,0 & 1 & 0,2 & 114,4 & 0 & 0,0 & 0,0 & 0 & 0,0 & 0,0 \\
\hline 14 & 131,5 & 133,444 & 488 & 4 & 0,8 & 533,8 & 0 & 0,0 & 0,0 & 0 & 0,0 & 0,0 & 0 & 0,0 & 0,0 \\
\hline 15 & 140,5 & 194,534 & 541 & 2 & 0,4 & 389,1 & 0 & 0,0 & 0,0 & 0 & 0,0 & 0,0 & 1 & 0,2 & 194,5 \\
\hline 16 & 150,5 & 254,669 & 858 & 1 & 0,1 & 254,7 & 0 & 0,0 & 0,0 & 0 & 0,0 & 0,0 & 0 & 0,0 & 0,0 \\
\hline 17 & 160,5 & 336,829 & 947 & 1 & 0,1 & 336,8 & 0 & 0,0 & 0,0 & 0 & 0,0 & 0,0 & 1 & 0,1 & 336,8 \\
\hline 18 & 170,5 & 405,477 & 1000 & 2 & 0,2 & 811,0 & 0 & 0,0 & 0,0 & 0 & 0,0 & 0,0 & 0 & 0,0 & 0,0 \\
\hline 19 & 180,5 & 341,247 & 1119 & 0 & 0,0 & 0,0 & 1 & 0,1 & 341,2 & 0 & 0,0 & 0,0 & 0 & 0,0 & 0,0 \\
\hline 20 & 190,5 & 276,772 & 1239 & 1 & 0,1 & 276,8 & 0 & 0,0 & 0,0 & 0 & 0,0 & 0,0 & 0 & 0,0 & 0,0 \\
\hline 21 & 201,5 & 176,707 & 829 & 0 & 0,0 & 0,0 & 0 & 0,0 & 0,0 & 0 & 0,0 & 0,0 & 0 & 0,0 & 0,0 \\
\hline 22 & 210,5 & 210,849 & 859 & 3 & 0,3 & 632,5 & 0 & 0,0 & 0,0 & 0 & 0,0 & 0,0 & 0 & 0,0 & 0,0 \\
\hline 23 & 220,5 & 218,176 & 765 & 2 & 0,3 & 436,4 & 0 & 0,0 & 0,0 & 0 & 0,0 & 0,0 & 0 & 0,0 & 0,0 \\
\hline 24 & 230,5 & 216,228 & 715 & 2 & 0,3 & 432,5 & 1 & 0,1 & 216,2 & 2 & 0,3 & 432,5 & 0 & 0,0 & 0,0 \\
\hline 25 & 240,5 & 290,364 & 670 & 2 & 0,3 & 580,7 & 0 & 0,0 & 0,0 & 0 & 0,0 & 0,0 & 0 & 0,0 & 0,0 \\
\hline 26 & 250,5 & 144,557 & 741 & 3 & 0,4 & 433,7 & 0 & 0,0 & 0,0 & 0 & 0,0 & 0,0 & 0 & 0,0 & 0,0 \\
\hline 27 & 260,5 & 162,655 & 687 & 3 & 0,4 & 488,0 & 0 & 0,0 & 0,0 & 2 & 0,3 & 325,3 & 0 & 0,0 & 0,0 \\
\hline 28 & 271,5 & 332,833 & 761 & 4 & 0,5 & 1331,3 & 4 & 0,5 & 1331,3 & 0 & 0,0 & 0,0 & 0 & 0,0 & 0,0 \\
\hline 29 & 280,5 & 130,075 & 456 & 0 & 0,0 & 0,0 & 3 & 0,7 & 390,2 & 2 & 0,4 & 260,1 & 0 & 0,0 & 0,0 \\
\hline 30 & 290,5 & 473,217 & 0,0 & 0,0 & 0,0 & 0,0 & 0,0 & 0,0 & 0,0 & 0,0 & 0,0 & 0,0 & 0,0 & 0,0 & 0,0 \\
\hline 31 & 314,5 & 334,253 & 0,0 & 0,0 & 0,0 & 0,0 & 0,0 & 0,0 & 0,0 & 0,0 & 0,0 & 0,0 & 0,0 & 0,0 & 0,0 \\
\hline 32 & 345,5 & 612,398 & 0,0 & 0,0 & 0,0 & 0,0 & 0,0 & 0,0 & 0,0 & 0,0 & 0,0 & 0,0 & 0,0 & 0,0 & 0,0 \\
\hline
\end{tabular}


TABELA 3.3: Qualificação e quantificação dos tipos polínicos da Lagoa Bonita, DF

continuação

\begin{tabular}{|c|c|c|c|c|c|c|c|c|c|c|c|c|c|c|c|}
\hline \multirow{2}{*}{ NIVEL } & \multirow{2}{*}{$\begin{array}{l}\text { PROF. } \\
(\mathrm{cm})\end{array}$} & \multirow{2}{*}{ B } & \multirow{2}{*}{ NTO } & \multicolumn{3}{|c|}{ Tipo Lafoensia - 1084} & \multicolumn{3}{|c|}{ Tipo Neea - 1131} & \multicolumn{3}{|c|}{ Tipo Byrsonima - 1024} & \multicolumn{3}{|c|}{ Tipo Andira - 1102} \\
\hline & & & & Norắos & $\mathbf{P}(\%)$ & $\mathbf{C}$ & $\mathrm{N}^{\circ} \mathrm{Grazos}$ & $P(\%)$ & C & N. Grấos & $P(\%)$ & C & Norăos & $\mathbf{P}(\%)$ & $\mathbf{C}$ \\
\hline \multicolumn{16}{|l|}{$\mathbf{8 1}$} \\
\hline 1 & 5,5 & 45,1223 & 922 & 2 & 0,2 & 90,2 & 0 & 0,0 & 0,0 & 4 & 0,4 & 180,5 & 0 & 0,0 & 0,0 \\
\hline 2 & 10,5 & 119,28 & 778 & 3 & 0,4 & 357,8 & 0 & 0,0 & 0,0 & 5 & 0,6 & 596,4 & 0 & 0,0 & 0,0 \\
\hline 3 & 20,5 & 69,303 & 877 & 0 & 0,0 & 0,0 & 0 & 0,0 & 0,0 & 10 & 1,1 & 693,0 & 1 & 0,1 & 69,3 \\
\hline 4 & 30,5 & 60,8859 & 962 & 2 & 0,2 & 121,8 & 0 & 0,0 & 0,0 & 4 & 0,4 & 243,5 & 0 & 0,0 & 0,0 \\
\hline 5 & 40,5 & 59,0672 & 903 & 0 & 0,0 & 0,0 & 1 & 0,1 & 59,1 & 6 & 0,7 & 354,4 & 0 & 0,0 & 0,0 \\
\hline 6 & 51,5 & 62,4266 & 930 & 0 & 0,0 & 0,0 & 0 & 0,0 & 0,0 & 4 & 0,4 & 249,7 & 0 & 0,0 & 0,0 \\
\hline 7 & 61,5 & 144,582 & 520 & 3 & 0,6 & 433,7 & 0 & 0,0 & 0,0 & 9 & 1,7 & 1301,2 & 0 & 0,0 & 0,0 \\
\hline 8 & 70,5 & 39,9528 & 744 & 2 & 0,3 & 79,9 & 0 & 0,0 & 0,0 & 18 & 2,4 & 719,2 & 0 & 0,0 & 0,0 \\
\hline 9 & 80,5 & 95,5277 & 871 & 4 & 0,5 & 382,1 & 0 & 0,0 & 0,0 & 3 & 0,3 & 286,6 & 1 & 0,1 & 95,5 \\
\hline 10 & 90,5 & 30,138 & 341 & 0 & 0,0 & 0,0 & 4 & 1,2 & 120,6 & 0 & 0,0 & 0,0 & 1 & 0,3 & 30,1 \\
\hline 11 & 101,5 & 61,5586 & 702 & 1 & 0,1 & 61,6 & 0 & 0,0 & 0,0 & 1 & 0,1 & 61,6 & 3 & 0,4 & 184,7 \\
\hline 12 & 110,5 & 89,4261 & 537 & 1 & 0,2 & 89,4 & 0 & 0,0 & 0,0 & 0 & 0,0 & 0,0 & 0 & 0,0 & 0,0 \\
\hline 13 & 120,5 & 114,361 & 510 & 4 & 0,8 & 457,4 & 0 & 0,0 & 0,0 & 0 & 0,0 & 0,0 & 0 & 0,0 & 0,0 \\
\hline 14 & 131,5 & 133,444 & 488 & 0 & 0,0 & 0,0 & 0 & 0,0 & 0,0 & 1 & 0,2 & 133,4 & 2 & 0,4 & 266,9 \\
\hline 15 & 140,5 & 194,534 & 541 & 1 & 0,2 & 194,5 & 4 & 0,7 & 778,1 & 0 & 0,0 & 0,0 & 1 & 0,2 & 194,5 \\
\hline 16 & 150,5 & 254,669 & 858 & 0 & 0,0 & 0,0 & 0 & 0,0 & 0,0 & 0 & 0,0 & 0,0 & 0 & 0,0 & 0,0 \\
\hline 17 & 160,5 & 336,829 & 947 & 0 & 0,0 & 0,0 & 2 & 0,2 & 673,7 & 0 & 0,0 & 0,0 & 0 & 0,0 & 0,0 \\
\hline 18 & 170,5 & 405,477 & 1000 & 0 & 0,0 & 0,0 & 4 & 0,4 & 1621,9 & 0 & 0,0 & 0,0 & 1 & 0,1 & 405,5 \\
\hline 19 & 180,5 & 341,247 & 1119 & 0 & 0,0 & 0,0 & 4 & 0,4 & 1365,0 & 0 & 0,0 & 0,0 & 0 & 0,0 & 0,0 \\
\hline 20 & 190,5 & 276,772 & 1239 & 0 & 0,0 & 0,0 & 5 & 0,4 & 1383,9 & 0 & 0,0 & 0,0 & 0 & 0,0 & 0,0 \\
\hline 21 & 201,5 & 176,707 & 829 & 1 & 0,1 & 176,7 & 3 & 0,4 & 530,1 & 0 & 0,0 & 0,0 & 2 & 0,2 & 353,4 \\
\hline 22 & 210,5 & 210,849 & 859 & 0 & 0,0 & 0,0 & 2 & 0,2 & 421,7 & 0 & 0,0 & 0,0 & 0 & 0,0 & 0,0 \\
\hline 23 & 220,5 & 218,176 & 765 & 0 & 0,0 & 0,0 & 1 & 0,1 & 218,2 & 0 & 0,0 & 0,0 & 0 & 0,0 & 0,0 \\
\hline 24 & 230,5 & 216,228 & 715 & 0 & 0,0 & 0,0 & 1 & 0,1 & 216,2 & 0 & 0,0 & 0,0 & 0 & 0,0 & 0,0 \\
\hline 25 & 240,5 & 290,364 & 670 & 2 & 0,3 & 580,7 & 0 & 0,0 & 0,0 & 0 & 0,0 & 0,0 & 0 & 0,0 & 0,0 \\
\hline 26 & 250,5 & 144,557 & 741 & 0 & 0,0 & 0,0 & 2 & 0,3 & 289,1 & 0 & 0,0 & 0,0 & 2 & 0,3 & 289,1 \\
\hline 27 & 260,5 & 162,655 & 687 & 1 & 0,1 & 162,7 & 4 & 0,6 & 650,6 & 1 & 0,1 & 162,7 & 2 & 0,3 & 325,3 \\
\hline 28 & 271,5 & 332,833 & 761 & 0 & 0,0 & 0,0 & 8 & 1,1 & 2662,7 & 0 & 0,0 & 0,0 & 3 & 0,4 & 998,5 \\
\hline 29 & 280,5 & 130,075 & 456 & 0 & 0,0 & 0,0 & 1 & 0,2 & 130,1 & 0 & 0,0 & 0,0 & 0 & 0,0 & 0,0 \\
\hline 30 & 290,5 & 473,217 & 0,0 & 0,0 & 0,0 & 0,0 & 0,0 & 0,0 & 0,0 & 0,0 & 0,0 & 0,0 & 0,0 & 0,0 & 0,0 \\
\hline 31 & 314,5 & 334,253 & 0,0 & 0,0 & 0,0 & 0,0 & 0,0 & 0,0 & 0,0 & 0,0 & 0,0 & 0,0 & 0,0 & 0,0 & 0,0 \\
\hline 32 & 345,5 & 612,398 & 0,0 & 0,0 & 0,0 & 0,0 & 0,0 & 0,0 & 0,0 & 0,0 & 0,0 & 0,0 & 0,0 & 0,0 & 0,0 \\
\hline
\end{tabular}


TABELA 3.3: Qualificação e quantificação dos tipos polínicos da Lagoa Bonita, DF

continuação

\begin{tabular}{|c|c|c|c|c|c|c|c|c|c|c|c|c|c|c|c|}
\hline \multirow{2}{*}{ NIVEL } & \multirow{2}{*}{$\begin{array}{l}\text { PROF. } \\
\text { (cm) }\end{array}$} & \multirow{2}{*}{ B } & \multirow{2}{*}{ NTO } & \multicolumn{3}{|c|}{ Tipo Roupala - 1114} & \multicolumn{3}{|c|}{ Tipo Pterodon - 1083} & \multicolumn{3}{|c|}{ Tipo Psoudobombax - 1141} & \multicolumn{3}{|c|}{ Tipo Kielmeyera - 1126} \\
\hline & & & & No Grăos & $P(\%)$ & C & $N^{0}$ Grãos & $P(\%)$ & C & $N^{\circ}$ Gräos & $P(\%)$ & $\mathrm{C}$ & $N^{0}$ Gräos & $P(\%)$ & $\mathrm{C}$ \\
\hline S1 & & 0 & & & & & & & & & & & & & \\
\hline 1 & 5,5 & 45,1223 & 922 & 0 & 0,0 & 0,0 & 0 & 0,0 & 0,0 & 0 & 0,0 & 0,0 & 0 & 0,0 & 0,0 \\
\hline 2 & 10,5 & 119,28 & 778 & 0 & 0,0 & 0,0 & 0 & 0,0 & 0,0 & 1 & 0,1 & 119,3 & 0 & 0,0 & 0,0 \\
\hline 3 & 20,5 & 69,303 & 877 & 0 & 0,0 & 0,0 & 3 & 0,3 & 207,9 & 0 & 0,0 & 0,0 & 0 & 0,0 & 0,0 \\
\hline 4 & 30,5 & 60,8859 & 962 & 3 & 0,3 & 182,7 & 0 & 0,0 & 0,0 & 0 & 0,0 & 0,0 & 0 & 0,0 & 0,0 \\
\hline 5 & 40,5 & 59,0672 & 903 & 0 & 0,0 & 0,0 & 0 & 0,0 & 0,0 & 0 & 0,0 & 0,0 & 8 & 0,9 & 472,5 \\
\hline 6 & 51,5 & 62,4266 & 930 & 0 & 0,0 & 0,0 & 1 & 0,1 & 62,4 & 1 & 0,1 & 62,4 & 9 & 1,0 & 561,8 \\
\hline 7 & 61,5 & 144,582 & 520 & 0 & 0,0 & 0,0 & 1 & 0,2 & 144,6 & 0 & 0,0 & 0,0 & 0 & 0,0 & 0,0 \\
\hline 8 & 70,5 & 39,9528 & 744 & 0 & 0,0 & 0,0 & 0 & 0,0 & 0,0 & 0 & 0,0 & 0,0 & 2 & $\overline{0,3}$ & 79,9 \\
\hline 9 & 80,5 & 95,5277 & 871 & 1 & 0,1 & 95,5 & 0 & 0,0 & 0,0 & 1 & 0,1 & 95,5 & 0 & 0,0 & 0,0 \\
\hline 10 & 90,5 & 30,138 & 341 & 3 & 0,9 & 90,4 & 0 & 0,0 & 0,0 & 0 & 0,0 & 0,0 & 0 & 0,0 & 0,0 \\
\hline 11 & 101,5 & 61,5586 & 702 & 14 & 2,0 & 861,8 & 0 & 0,0 & 0,0 & 0 & 0,0 & 0,0 & 0 & 0,0 & 0,0 \\
\hline 12 & 110,5 & 89,4261 & 537 & 4 & 0,7 & 357,7 & 0 & 0,0 & 0,0 & 0 & 0,0 & 0,0 & 0 & 0,0 & 0,0 \\
\hline 13 & 120,5 & 114,361 & 510 & 0 & 0,0 & 0,0 & 0 & 0,0 & 0,0 & 0 & 0,0 & 0,0 & 0 & 0,0 & 0,0 \\
\hline 14 & 131,5 & 133,444 & 488 & 0 & 0,0 & 0,0 & 0 & 0,0 & 0,0 & 0 & 0,0 & 0,0 & 0 & 0,0 & 0,0 \\
\hline 15 & 140,5 & 194,534 & 541 & 0 & 0,0 & 0,0 & 0 & 0,0 & 0,0 & 0 & 0,0 & 0,0 & 0 & 0,0 & 0,0 \\
\hline 16 & 150,5 & 254,669 & 858 & 0 & 0,0 & 0,0 & 0 & 0,0 & 0,0 & 0 & 0,0 & 0,0 & 0 & 0,0 & 0,0 \\
\hline 17 & 160,5 & 336,829 & 947 & 3 & 0,3 & 1010,5 & 0 & 0,0 & 0,0 & 0 & 0,0 & 0,0 & 0 & 0,0 & 0,0 \\
\hline 18 & 170,5 & 405,477 & 1000 & 0 & 0,0 & 0,0 & 0 & 0,0 & 0,0 & 0 & 0,0 & 0,0 & 0 & 0,0 & 0,0 \\
\hline 19 & 180,5 & 341,247 & 1119 & 0 & 0,0 & 0,0 & 0 & 0,0 & 0,0 & 0 & 0,0 & 0,0 & 0 & 0,0 & 0,0 \\
\hline 20 & 190,5 & 276,772 & 1239 & 0 & 0,0 & 0,0 & 0 & 0,0 & 0,0 & 0 & 0,0 & 0,0 & 0 & 0,0 & 0,0 \\
\hline 21 & 201,5 & 176,707 & 829 & 0 & 0,0 & 0,0 & 0 & 0,0 & 0,0 & 0 & 0,0 & 0,0 & 0 & 0,0 & 0,0 \\
\hline 22 & 210,5 & 210,849 & 859 & 0 & 0,0 & 0,0 & 0 & 0,0 & 0,0 & 0 & 0,0 & 0,0 & 0 & 0,0 & 0,0 \\
\hline 23 & 220,5 & 218,176 & 765 & 0 & 0,0 & 0,0 & 0 & 0,0 & 0,0 & 0 & 0,0 & 0,0 & 0 & 0,0 & 0,0 \\
\hline 24 & 230,5 & 216,228 & 715 & 0 & 0,0 & 0,0 & 0 & 0,0 & 0,0 & 0 & 0,0 & 0,0 & 0 & 0,0 & 0,0 \\
\hline 25 & 240,5 & 290,364 & 670 & 0 & 0,0 & 0,0 & 0 & 0,0 & 0,0 & 0 & 0,0 & 0,0 & 0 & 0,0 & 0,0 \\
\hline 26 & 250,5 & 144,557 & 741 & 0 & 0,0 & 0,0 & 0 & 0,0 & 0,0 & 0 & 0,0 & 0,0 & 0 & 0,0 & 0,0 \\
\hline 27 & 260,5 & 162,655 & 687 & 0 & 0,0 & 0,0 & 0 & 0,0 & 0,0 & 0 & 0,0 & 0,0 & 0 & 0,0 & 0,0 \\
\hline 28 & 271,5 & 332,833 & 761 & 1 & 0,1 & 332,8 & 0 & 0,0 & 0,0 & 0 & 0,0 & 0,0 & 0 & 0,0 & 0,0 \\
\hline 29 & 280,5 & 130,075 & 456 & 0 & 0,0 & 0,0 & 0 & 0,0 & 0,0 & 0 & 0,0 & 0,0 & 0 & 0,0 & 0,0 \\
\hline 30 & 290,5 & 473,217 & 0,0 & 0,0 & 0,0 & 0,0 & 0,0 & 0,0 & 0,0 & 0,0 & 0,0 & 0,0 & 0,0 & 0,0 & 0,0 \\
\hline 31 & 314,5 & 334,253 & 0,0 & 0,0 & 0,0 & 0,0 & 0,0 & 0,0 & 0,0 & 0,0 & 0,0 & 0,0 & 0,0 & 0,0 & 0,0 \\
\hline 32 & 345,5 & 612,398 & 0,0 & 0,0 & 0,0 & 0,0 & 0,0 & 0,0 & 0,0 & 0,0 & 0,0 & 0,0 & 0,0 & 0,0 & 0,0 \\
\hline
\end{tabular}


TABELA 3.3: Qualificação e quantificação dos tipos polínicos da Lagoa Bonita, DF

\begin{tabular}{|c|c|c|c|c|c|c|c|c|c|c|c|c|c|c|c|}
\hline \multirow{2}{*}{ NIVEL } & \multirow{2}{*}{$\begin{array}{l}\text { PROF. } \\
\text { (cm) }\end{array}$} & \multirow{2}{*}{ B } & \multirow{2}{*}{ NTO } & \multicolumn{3}{|c|}{ Tipo Stryphnodendron - 1042} & \multicolumn{3}{|c|}{ Tipo Brosimum - 1014} & \multicolumn{3}{|c|}{ Tipo Curatella - 1027} & \multicolumn{3}{|c|}{ Tipo Anacardiaceae A - $\mathbf{1 1 2 4}$} \\
\hline & & & & No Gráos $^{0}$ & $\mathbf{P ( \% )}$ & C & $\mathrm{N}^{\circ}$ Crãos & $P(\%)$ & C & No Graos $^{\circ}$ & $P(\%)$ & $c$ & No Grãos & $P(\%)$ & C \\
\hline S1 & 1 & & & & & & & & & & & & & & \\
\hline 1 & 5,5 & 45,1223 & 922 & 11 & 1,2 & 496,3 & 7 & 0,8 & 315,9 & 5 & 0,5 & 225,6 & 24 & 2,6 & 1082,9 \\
\hline 2 & 10,5 & 119,28 & 778 & 17 & 2,2 & 2027,8 & 31 & 4,0 & 3697,7 & 6 & 0,8 & 715,7 & 11 & 1,4 & 1312,1 \\
\hline 3 & 20,5 & 69,303 & 877 & 34 & 3,9 & 2356,3 & 17 & 1,9 & 1178,2 & 7 & 0,8 & 485,1 & 27 & 3,1 & 1871,2 \\
\hline 4 & 30,5 & 60,8859 & 962 & 43 & 4,5 & 2618,1 & 12 & 1,2 & 730,6 & 1 & 0,1 & 60,9 & 30 & 3,1 & 1826,6 \\
\hline 5 & 40,5 & 59,0672 & 903 & 59 & 6,5 & 3485,0 & 4 & 0,4 & 236,3 & 4 & 0,4 & 236,3 & 69 & 7,6 & 4075,6 \\
\hline$\overline{6}$ & 51,5 & 62,4266 & 930 & 46 & 4,9 & 2871,6 & 2 & 0,2 & 124,9 & 14 & 1,5 & 874,0 & 66 & 7,1 & 4120,2 \\
\hline 7 & 61,5 & 144,582 & 520 & 15 & 2,9 & 2168,7 & 4 & 0,8 & 578,3 & 0 & 0,0 & 0,0 & 32 & 6,2 & 4626,6 \\
\hline 8 & 70,5 & 39,9528 & 744 & 20 & 2,7 & 799,1 & 7 & $0, \overline{9}$ & 279,7 & 0 & 0,0 & 0,0 & 33 & 4,4 & 1318,4 \\
\hline 9 & 80,5 & 95,5277 & 871 & 7 & 0,8 & 668,7 & 0 & 0,0 & 0,0 & 0 & 0,0 & 0,0 & 82 & 9,4 & 7833,3 \\
\hline 10 & 90,5 & 30,138 & 341 & 2 & 0,6 & 60,3 & 0 & 0,0 & 0,0 & 0 & 0,0 & 0,0 & 6 & 1,8 & 180,8 \\
\hline 11 & 101,5 & 61,5586 & 702 & 4 & 0,6 & 246,2 & 7 & 1,0 & 430,9 & $\overline{0}$ & 0,0 & 0,0 & 10 & 1,4 & 615,6 \\
\hline 12 & 110.5 & 89,4261 & 537 & 0 & 0,0 & 0,0 & 7 & 1,3 & 626,0 & 0 & 0,0 & 0,0 & 1 & 0,2 & 89,4 \\
\hline 13 & 120,5 & 114,361 & 510 & 1 & 0,2 & 114,4 & 15 & 2,9 & 1715,4 & 0 & 0,0 & 0,0 & 1 & 0,2 & 114,4 \\
\hline 14 & 131.5 & 133,444 & 488 & 0 & 0,0 & 0,0 & 3 & 0,6 & 400,3 & 0 & 0,0 & 0,0 & 2 & 0,4 & 266,9 \\
\hline 15 & 140,5 & 194,534 & 541 & 0 & 0,0 & 0,0 & 0 & 0,0 & 0,0 & 0 & 0,0 & 0,0 & 0 & 0,0 & 0,0 \\
\hline 16 & 150,5 & 254,669 & 858 & 0 & 0,0 & 0,0 & 0 & 0,0 & 0,0 & 0 & 0,0 & 0,0 & 0 & 0,0 & 0,0 \\
\hline 17 & 160,5 & 336,829 & 947 & 0 & 0,0 & 0,0 & 0 & 0,0 & 0,0 & 0 & 0,0 & 0,0 & 0 & 0,0 & 0,0 \\
\hline 18 & 170,5 & 405,477 & 1000 & 0 & 0,0 & 0,0 & 0 & 0,0 & 0,0 & 0 & 0,0 & 0,0 & 2 & 0,2 & 811,0 \\
\hline 19 & 180,5 & 341,247 & 1119 & 0 & 0,0 & 0,0 & 0 & 0,0 & 0,0 & 0 & 0,0 & 0,0 & 9 & 0,8 & 3071,2 \\
\hline 20 & 190,5 & 276,772 & 1239 & 0 & 0,0 & 0,0 & 0 & 0,0 & 0,0 & 0 & 0,0 & 0,0 & 0 & 0,0 & 0,0 \\
\hline 21 & 201,5 & 176,707 & 829 & 0 & 0,0 & 0,0 & 0 & 0,0 & 0,0 & 1 & 0,1 & 176,7 & 3 & 0,4 & 530,1 \\
\hline 22 & 210,5 & 210,849 & 859 & 0 & 0,0 & 0,0 & 0 & 0,0 & 0,0 & 0 & 0,0 & 0,0 & 0 & 0,0 & 0,0 \\
\hline 23 & 220.5 & 218,176 & 765 & 0 & 0,0 & 0,0 & 0 & 0,0 & 0,0 & 0 & 0,0 & 0,0 & 1 & 0,1 & 218,2 \\
\hline 24 & 230,5 & 216,228 & 715 & 2 & 0,3 & 432,5 & 0 & 0,0 & 0,0 & 1 & 0,1 & 216,2 & 1 & 0,1 & 216,2 \\
\hline 25 & 240.5 & 290,364 & 670 & 0 & 0,0 & 0,0 & 0 & 0,0 & 0,0 & 0 & 0,0 & 0,0 & 0 & 0,0 & 0,0 \\
\hline 26 & 250,5 & 144,557 & 741 & 3 & 0,4 & 433,7 & 0 & 0,0 & 0,0 & 0 & 0,0 & 0,0 & 4 & 0,5 & 578,2 \\
\hline 27 & 260.5 & 162,655 & 687 & 0 & 0,0 & 0,0 & 0 & 0,0 & 0,0 & 0 & 0,0 & 0,0 & 1 & 0,1 & 162,7 \\
\hline 28 & 271,5 & 332,833 & 761 & 2 & 0,3 & 665,7 & 0 & 0,0 & 0,0 & 0 & 0,0 & 0,0 & 0 & 0,0 & 0,0 \\
\hline 29 & 280,5 & 130,075 & 456 & 0 & 0,0 & 0,0 & 0 & 0,0 & 0,0 & 0 & 0,0 & 0,0 & 2 & 0,4 & 260,1 \\
\hline 30 & 290,5 & 473,217 & 0,0 & 0,0 & 0,0 & 0,0 & 0,0 & 0,0 & 0,0 & 0,0 & 0,0 & 0,0 & 0,0 & 0,0 & 0,0 \\
\hline 31 & 314,5 & 334,253 & 0,0 & 0,0 & 0,0 & 0,0 & 0,0 & 0,0 & 0,0 & 0,0 & 0,0 & 0,0 & 0,0 & 0,0 & 0,0 \\
\hline 32 & 345,5 & 612,398 & 0,0 & 0,0 & 0,0 & 0,0 & 0,0 & 0,0 & 0,0 & 0,0 & 0,0 & 0,0 & 0,0 & 0,0 & 0,0 \\
\hline
\end{tabular}


TABELA 3.3: Qualificação e quantificação dos tipos polínicos da Lagoa Bonita, DF

\begin{tabular}{|c|c|c|c|c|c|c|c|c|c|c|c|c|c|c|c|}
\hline \multirow{2}{*}{ NIVEL. } & \multirow{2}{*}{$\begin{array}{l}\text { PROF, } \\
(\mathrm{cm})\end{array}$} & \multirow{2}{*}{ B } & \multirow{2}{*}{ NTO } & \multicolumn{3}{|c|}{ Tipo Harpalyce - 1091} & \multicolumn{3}{|c|}{ Tipo Sclerolobium - 1068} & \multicolumn{3}{|c|}{ Tipo Erythroxylum - 1120} & \multicolumn{3}{|c|}{ Tipo Waltheria - 1149} \\
\hline & & & & No Grắos & $P(\%)$ & C & No Grăos & $P(\%)$ & C & No Grắos & $\mathbf{P}(\%)$ & $\mathbf{C}$ & No Grằos & $P(\%)$ & C \\
\hline \$1 & & & & & & & & & & & & & & & \\
\hline 1 & 5,5 & 45,1223 & 922 & 2 & 0,2 & 90,2 & 0 & 0,0 & 0,0 & $\overline{0}$ & 0,0 & 0,0 & 2 & 0,2 & 90,2 \\
\hline 2 & 10,5 & 119,28 & 778 & 0 & 0,0 & 0,0 & 0 & 0,0 & 0,0 & 0 & 0,0 & 0,0 & 0 & 0,0 & 0,0 \\
\hline 3 & 20,5 & 69,303 & 877 & 1 & 0,1 & 69,3 & 0 & 0,0 & 0,0 & 0 & 0,0 & 0,0 & 0 & 0,0 & 0,0 \\
\hline 4 & 30,5 & 60,8859 & 962 & $\overline{0}$ & 0,0 & 0,0 & 0 & 0,0 & 0,0 & 2 & 0,2 & 121,8 & 0 & 0,0 & 0,0 \\
\hline 5 & 40,5 & 59,0672 & 903 & 1 & 0,1 & 59,1 & 0 & 0,0 & 0,0 & 1 & 0,1 & 59,1 & 0 & 0,0 & 0,0 \\
\hline 6 & 51,5 & 62,4266 & 930 & 0 & 0,0 & 0,0 & 0 & 0,0 & 0,0 & 1 & 0,1 & 62,4 & 0 & 0,0 & 0,0 \\
\hline 7 & 61,5 & 144,582 & 520 & 0 & 0,0 & 0,0 & 0 & 0,0 & 0,0 & 0 & 0,0 & 0,0 & 1 & $\overline{0,2}$ & 144,6 \\
\hline 8 & 70,5 & 39,9528 & 744 & 0 & 0,0 & 0,0 & 0 & 0,0 & 0,0 & 0 & 0,0 & 0,0 & 1 & 0,1 & 40,0 \\
\hline 9 & 80,5 & 95,5277 & 871 & 0 & 0,0 & 0,0 & 0 & 0,0 & 0,0 & 1 & 0,1 & 95,5 & 3 & 0,3 & 286,6 \\
\hline 10 & 90,5 & 30,138 & 341 & 0 & 0,0 & 0,0 & 0 & 0,0 & 0,0 & 0 & 0,0 & 0,0 & 1 & 0,3 & 30,1 \\
\hline 11 & 104,5 & 61,5586 & 702 & 4 & 0,6 & 246,2 & 0 & 0,0 & 0,0 & 0 & 0,0 & 0,0 & 2 & 0,3 & 123,1 \\
\hline 12 & 110,5 & 89,4261 & 537 & 2 & 0,4 & 178,9 & 0 & 0,0 & 0,0 & 0 & 0,0 & 0,0 & 0 & 0,0 & 0,0 \\
\hline 13 & 120,5 & 114,361 & 510 & 0 & 0,0 & 0,0 & 0 & $c, 0$ & 0,0 & 0 & 0,0 & 0,0 & 1 & 0,2 & 114,4 \\
\hline 14 & 131,5 & 133,444 & 488 & 0 & 0,0 & 0,0 & 0 & 0,0 & 0,0 & 0 & 0,0 & 0,0 & 0 & 0,0 & 0,0 \\
\hline 15 & 140,5 & 194,534 & 541 & 0 & 0,0 & 0,0 & $\overline{0}$ & 0,0 & 0,0 & 0 & 0,0 & 0,0 & 0 & 0,0 & 0,0 \\
\hline 16 & 150,5 & 254,669 & 858 & 0 & 0,0 & 0,0 & 0 & 0,0 & 0,0 & 0 & 0,0 & 0,0 & 0 & 0,0 & 0,0 \\
\hline 17 & 160,5 & 336,829 & 947 & 0 & 0,0 & 0,0 & 0 & 0,0 & 0,0 & 0 & 0,0 & 0,0 & 1 & 0,1 & 336,8 \\
\hline 18 & 170,5 & 405,477 & 1000 & 3 & 0,3 & 1216,4 & 0 & 0,0 & 0,0 & 0 & 0,0 & 0,0 & 0 & 0,0 & 0,0 \\
\hline 19 & 180,5 & 341,247 & 1119 & 0 & 0,0 & 0,0 & 2 & 0,2 & 682,5 & 0 & 0,0 & 0,0 & 0 & 0,0 & 0,0 \\
\hline 20 & 190,5 & 276,772 & 1239 & 0 & 0,0 & 0,0 & 0 & 0,0 & 0,0 & 0 & 0,0 & 0,0 & 0 & 0,0 & 0,0 \\
\hline 21 & 201,5 & 176,707 & 829 & 0 & 0,0 & 0,0 & 0 & 0,0 & 0,0 & 0 & 0,0 & 0,0 & 0 & 0,0 & 0,0 \\
\hline 22 & 210,5 & 210,849 & 859 & 2 & 0,2 & 421,7 & 0 & 0,0 & 0,0 & 0 & 0,0 & 0,0 & 2 & 0,2 & 421,7 \\
\hline 23 & 220,5 & 218,176 & 765 & 0 & 0,0 & 0,0 & 0 & 0,0 & 0,0 & 0 & 0,0 & 0,0 & 0 & 0,0 & 0,0 \\
\hline 24 & 230,5 & 216,228 & 715 & 0 & 0,0 & 0,0 & 0 & 0,0 & 0,0 & 0 & 0,0 & 0,0 & 0 & 0,0 & 0,0 \\
\hline 25 & 240,5 & 290,364 & 670 & 1 & 0,1 & 290,4 & 0 & 0,0 & 0,0 & 0 & 0,0 & 0,0 & 0 & 0,0 & 0,0 \\
\hline 26 & 250,5 & 144,557 & 741 & 0 & 0,0 & 0,0 & 0 & 0,0 & 0,0 & 0 & 0,0 & 0,0 & $\overline{0}$ & 0,0 & 0,0 \\
\hline 27 & 260,5 & 162,655 & 687 & 0 & 0,0 & 0,0 & 0 & 0,0 & 0,0 & 0 & 0,0 & 0,0 & 0 & 0,0 & 0,0 \\
\hline 28 & 271,5 & 332,833 & 761 & 1 & 0,1 & 332,8 & 0 & 0,0 & 0,0 & 0 & 0,0 & 0,0 & 0 & 0,0 & 0,0 \\
\hline 29 & 280,5 & 130,075 & 456 & 1 & 0,2 & 130,1 & 0 & 0,0 & 0,0 & 0 & 0,0 & 0,0 & 0 & 0,0 & 0,0 \\
\hline 30 & 290,5 & 473,217 & 0,0 & 0,0 & 0,0 & 0,0 & 0,0 & 0,0 & 0,0 & 0,0 & 0,0 & 0,0 & 0,0 & 0,0 & 0,0 \\
\hline 31 & 314,5 & 334,253 & 0,0 & 0,0 & 0,0 & 0,0 & 0,0 & 0,0 & 0,0 & 0,0 & 0,0 & 0,0 & 0,0 & 0,0 & 0,0 \\
\hline 32 & 345.5 & 612,398 & 0,0 & 0,0 & 0,0 & 0,0 & 0,0 & 0,0 & 0,0 & 0,0 & 0,0 & 0,0 & 0,0 & 0,0 & 0,0 \\
\hline
\end{tabular}


TABELA 3.3: Qualificação e quantificação dos tipos polínicos da Lagoa Bonita, DF

continuação

\begin{tabular}{|c|c|c|c|c|c|c|c|c|c|c|c|c|c|c|c|}
\hline \multirow{2}{*}{ NIVEL } & \multirow{2}{*}{$\begin{array}{l}\text { PROF. } \\
\text { (cm) }\end{array}$} & \multirow{2}{*}{ B } & \multirow{2}{*}{ NTO } & \multicolumn{3}{|c|}{ Tipo Agonandra - 1130} & \multicolumn{3}{|c|}{ Tipo Euplassa - 1056} & \multicolumn{3}{|c|}{ Tipo Eriotheca - 1112} & \multicolumn{3}{|c|}{ Tipo Sapium - 1158} \\
\hline & & & & No Grăos & $\mathbf{P}(\%)$ & C & No Grăos & $P(\%)$ & $\mathbf{C}$ & No Grăos & $P(\%)$ & C & No Gráos & $P(\%)$ & $C$ \\
\hline $\mathbf{S 1}$ & & & & & & & & & & & & & & & \\
\hline 1 & 5,5 & 45,1223 & 922 & 0 & 0,0 & 0,0 & 0 & 0,0 & 0,0 & 0 & 0,0 & 0,0 & 2 & 0,2 & 90,2 \\
\hline 2 & 10,5 & 119,28 & 778 & 0 & 0,0 & 0,0 & 5 & 0,6 & 596,4 & 0 & 0,0 & 0,0 & 0 & 0,0 & 0,0 \\
\hline 3 & 20,5 & 69,303 & 877 & 0 & 0,0 & 0,0 & 1 & 0,1 & 69,3 & 0 & 0,0 & 0,0 & 0 & 0,0 & 0,0 \\
\hline 4 & 30,5 & 60,8859 & 962 & 0 & 0,0 & 0,0 & 0 & 0,0 & 0,0 & 1 & 0,1 & 60,9 & 0 & 0.0 & 0,0 \\
\hline 5 & 40,5 & 59,0672 & 903 & 2 & 0,2 & 118,1 & 0 & 0,0 & 0,0 & 0 & 0,0 & 0,0 & 0 & 0,0 & 0,0 \\
\hline 6 & 51,5 & 62,4266 & 930 & 0 & 0,0 & 0,0 & 0 & 0,0 & 0,0 & 0 & 0,0 & 0,0 & 0 & 0,0 & 0,0 \\
\hline 7 & 61,5 & 144,582 & 520 & 0 & 0,0 & 0,0 & 1 & 0,2 & 144,6 & 0 & 0,0 & 0,0 & 0 & 0,0 & 0,0 \\
\hline 8 & 70,5 & 39,9528 & 744 & 0 & 0,0 & 0,0 & 0 & 0,0 & 0,0 & 0 & 0,0 & 0,0 & 0 & 0,0 & 0,0 \\
\hline 9 & 80,5 & 95,5277 & 871 & 0 & 0,0 & 0,0 & 6 & 0,7 & 573,2 & 0 & 0,0 & 0,0 & 0 & 0,0 & 0,0 \\
\hline 10 & 90,5 & 30,138 & 341 & 0 & 0,0 & 0,0 & 0 & 0,0 & 0,0 & 0 & 0,0 & 0,0 & 1 & 0,3 & 30,1 \\
\hline 11 & 101,5 & 61,5586 & 702 & 4 & 0,6 & 246,2 & 2 & 0,3 & 123,1 & 0 & 0,0 & 0,0 & 0 & 0,0 & 0,0 \\
\hline 12 & 110,5 & 89,4261 & 537 & 0 & 0,0 & 0,0 & 0 & 0,0 & 0,0 & 1 & 0,2 & 89,4 & 0 & 0,0 & 0,0 \\
\hline 13 & 120,5 & 114,361 & 510 & 1 & 0,2 & 114,4 & 0 & 0,0 & 0,0 & 0 & 0,0 & 0,0 & 0 & 0,0 & 0,0 \\
\hline 14 & 131,5 & 133,444 & 488 & 2 & 0,4 & 266,9 & 1 & 0,2 & 133,4 & 1 & 0,2 & 133,4 & 0 & 0,0 & 0,0 \\
\hline 15 & 140,5 & 194,534 & 541 & 2 & 0,4 & 389,1 & 0 & 0,0 & 0,0 & 3 & 0,6 & 583,6 & 0 & 0,0 & 0,0 \\
\hline 16 & 150,5 & 254,669 & 858 & 0 & 0,0 & 0,0 & 0 & 0,0 & 0,0 & 0 & 0,0 & 0,0 & 0 & 0,0 & 0,0 \\
\hline 17 & 160,5 & 336,829 & 947 & 0 & 0,0 & 0,0 & 0 & 0,0 & 0,0 & 0 & 0,0 & 0,0 & 0 & 0,0 & 0,0 \\
\hline 18 & 170,5 & 405,477 & 1000 & 0 & 0,0 & 0,0 & 0 & 0,0 & 0,0 & 0 & 0,0 & 0,0 & 0 & 0,0 & 0,0 \\
\hline 19 & 180,5 & 341,247 & 1119 & 0 & 0,0 & 0,0 & 0 & 0,0 & 0,0 & 0 & 0,0 & 0,0 & 0 & 0,0 & 0,0 \\
\hline 20 & 190,5 & 276,772 & 1239 & 0 & 0,0 & 0,0 & 1 & 0,1 & 276,8 & 0 & 0,0 & 0,0 & 0 & 0,0 & 0,0 \\
\hline 21 & 201,5 & 176,707 & 829 & 0 & 0,0 & 0,0 & 0 & 0,0 & 0,0 & 0 & 0,0 & 0,0 & 0 & 0,0 & 0,0 \\
\hline 22 & 210,5 & 210,849 & 859 & 0 & 0,0 & 0,0 & 0 & 0,0 & 0,0 & 0 & 0,0 & 0,0 & 0 & 0,0 & 0,0 \\
\hline 23 & 220,5 & 218,176 & 765 & 0 & 0,0 & 0,0 & 0 & 0,0 & 0,0 & 0 & 0,0 & 0,0 & 0 & 0,0 & 0,0 \\
\hline 24 & 230,5 & 216,228 & 715 & 2 & 0,3 & 432,5 & 0 & 0,0 & 0,0 & 1 & 0,1 & 216,2 & 0 & 0,0 & 0,0 \\
\hline 25 & 240,5 & 290,364 & 670 & 0 & 0,0 & 0,0 & 0 & 0,0 & 0,0 & 2 & 0,3 & 580,7 & 0 & 0,0 & 10,0 \\
\hline 26 & 250,5 & 144,557 & 741 & $\overline{0}$ & 0,0 & 0,0 & 0 & 0,0 & 0,0 & 0 & 0,0 & 0,0 & 0 & 0,0 & 0,0 \\
\hline 27 & 260,5 & 162,655 & 687 & 0 & 0,0 & 0,0 & 0 & 0,0 & 0,0 & 0 & 0,0 & 0,0 & 0 & 0,0 & 0,0 \\
\hline 28 & 271,5 & 332,833 & 761 & 0 & 0,0 & 0,0 & 0 & 0,0 & 0,0 & 0 & 0,0 & 0,0 & 0 & 0,0 & 0,0 \\
\hline 29 & 280,5 & 130,075 & 456 & 0 & 0,0 & 0,0 & 0 & 0,0 & 0,0 & 0 & 0,0 & 0,0 & 1 & 0,2 & 130,1 \\
\hline 30 & 290,5 & 473,217 & 0,0 & 0,0 & 0,0 & 0,0 & 0,0 & 0,0 & 0,0 & 0,0 & 0,0 & 0,0 & 0,0 & 0,0 & 0,0 \\
\hline 31 & 314,5 & 334,253 & 0,0 & 0,0 & 0,0 & 0,0 & 0,0 & 0,0 & 0,0 & 0,0 & 0,0 & 0,0 & 0,0 & 0,0 & 0,0 \\
\hline 32 & 345,5 & 612,398 & 0,0 & 0,0 & 0,0 & 0,0 & 0,0 & 0,0 & 0,0 & 0,0 & 0,0 & 0,0 & 0,0 & 0,0 & 0,0 \\
\hline
\end{tabular}




\begin{tabular}{|c|c|c|c|c|c|c|c|c|c|c|c|c|c|c|c|}
\hline \multirow{2}{*}{ NIVEL } & \multirow{2}{*}{$\begin{array}{l}\text { PROF. } \\
\text { (cm) }\end{array}$} & \multirow{2}{*}{ B } & \multirow{2}{*}{ NTO } & \multicolumn{3}{|c|}{ Tipo Solanaceae -1026} & \multicolumn{3}{|c|}{ Tipo Paimae - 1018} & \multicolumn{3}{|c|}{ Tipo Podocarpus - 1070} & \multicolumn{3}{|c|}{ Tipo Mimosa A - 1096} \\
\hline & & & & No Grátos & $P(\%)$ & C & No Gráos & $P(\%)$ & C & No Grasos & $P(\%)$ & c & No Gráos & $P(\%)$ & C \\
\hline$\overline{\text { s1 }}$ & & & & & & & & & & & & & & & \\
\hline 1 & 5,5 & 45,1223 & 922 & 6 & 0,7 & 270,7 & 20 & 2,2 & 902,4 & 1 & 0,1 & $\overline{45,1}$ & 4 & $\overline{0,4}$ & 180,5 \\
\hline 2 & 10,5 & 119,28 & 778 & $\overline{3}$ & 0,4 & 357,8 & 25 & 3,2 & 2982,0 & 2 & 0,3 & 238,6 & 4 & $\overline{0,5}$ & 477,1 \\
\hline 3 & 20,5 & 69,303 & 877 & 5 & 0,6 & 346,5 & 29 & 3,3 & 2009,8 & 0 & 0,0 & 0,0 & 4 & 0,5 & 277,2 \\
\hline 4 & 30,5 & 60,8859 & 962 & 5 & 0,5 & 304,4 & 27 & 2,8 & 1643,9 & 1 & 0,1 & 60,9 & 5 & $\overline{0,5}$ & 304,4 \\
\hline 5 & 40,5 & 59,0672 & 903 & $\overline{0}$ & 0,0 & 0,0 & 18 & 2,0 & 1063,2 & 0 & $0, \overline{0}$ & 0,0 & 2 & 0,2 & 118,1 \\
\hline 6 & 51,5 & 62,4266 & 930 & 0 & 0,0 & 0,0 & 19 & 2,0 & 1186,1 & 1 & 0,1 & 62,4 & 2 & 0,2 & 124,9 \\
\hline 7 & 61,5 & 144,582 & 520 & 3 & 0,6 & 433,7 & 5 & 1,0 & 722,9 & 0 & 0,0 & 0,0 & 6 & 1,2 & 867,5 \\
\hline 8 & 70,5 & 39,9528 & 744 & 2 & 0,3 & 79,9 & 12 & 1,6 & 479,4 & 1 & $\overline{0,1}$ & 40,0 & 4 & 0,5 & 159,8 \\
\hline 9 & 80,5 & 95,5277 & 871 & 5 & 0,6 & 477,6 & 6 & 0,7 & 573,2 & 0 & 0,0 & 0,0 & 0 & 0,0 & 0,0 \\
\hline 10 & 90,5 & 30,138 & 341 & 0 & 0,0 & 0,0 & 10 & 2,9 & 301,4 & 0 & 0,0 & 0,0 & 0 & 0,0 & 0,0 \\
\hline 11 & 101,5 & 61,5586 & 702 & 1 & 0,1 & 61,6 & 4 & 0,6 & 246,2 & 1 & $\overline{0,1}$ & 61,6 & 6 & 0,9 & 369,4 \\
\hline 12 & 110,5 & 89,4261 & 537 & $\overline{8}$ & 1,5 & 715,4 & 3 & 0,6 & 268,3 & 0 & 0,0 & 0,0 & 4 & 0,7 & 357,7 \\
\hline 13 & 120,5 & 114,361 & 510 & 1 & 0,2 & 114,4 & 2 & 0,4 & 228,7 & 0 & 0,0 & 0,0 & 3 & 0,6 & 343,1 \\
\hline 14 & 131,5 & 133,444 & 488 & 3 & 0,6 & 400,3 & 4 & 0,8 & 533,8 & 0 & 0,0 & 0,0 & 0 & 0,0 & 0,0 \\
\hline 15 & 140,5 & 194,534 & 541 & $\overline{0}$ & 0,0 & 0,0 & 1 & 0,2 & 194,5 & 1 & 0,2 & 194,5 & 1 & 0,2 & 194,5 \\
\hline 16 & 150,5 & 254,669 & 858 & 1 & 0,1 & 254,7 & 0 & 0,0 & 0,0 & 4 & 0,5 & 1018,7 & 0 & 0,0 & 0,0 \\
\hline 17 & 160,5 & 336,829 & 947 & 4 & 0,4 & 1347,3 & 0 & 0,0 & 0,0 & 5 & 0,5 & 1684,1 & 0 & 0,0 & 0,0 \\
\hline 18 & 170,5 & 405,477 & 1000 & 1 & 0,1 & 405,5 & 2 & 0,2 & 811,0 & 3 & 0,3 & 1216,4 & 0 & 0,0 & 0,0 \\
\hline 19 & 180,5 & 341,247 & 1119 & 2 & $\overline{0,2}$ & 682,5 & 5 & 0,4 & 1706,2 & 4 & 0,4 & 1365,0 & 1 & 0,1 & 341,2 \\
\hline 20 & 190,5 & 276,772 & 1239 & 8 & 0,6 & 2214,2 & 2 & 0,2 & 553,5 & 5 & 0,4 & 1383,9 & 0 & 0,0 & 0,0 \\
\hline 21 & 201,5 & 176,707 & 829 & 4 & 0,5 & 706,8 & 4 & 0,5 & 706,8 & 6 & 0,7 & 1060,2 & 1 & 0,1 & 176,7 \\
\hline 22 & 210,5 & 210,849 & 859 & 7 & 0,8 & 1475,9 & 2 & 0,2 & 421,7 & 4 & 0,5 & 843,4 & 1 & 0,1 & 210,8 \\
\hline 23 & 220,5 & 218,176 & 765 & 3 & 0,4 & 654,5 & 2 & 0,3 & 436,4 & 2 & 0,3 & 436,4 & 0 & 0,0 & 0,0 \\
\hline 24 & 230,5 & 216,228 & 715 & 7 & 1,0 & 1513,6 & 3 & 0,4 & 648,7 & 0 & 0,0 & 0,0 & 0 & 0,0 & 0,0 \\
\hline 25 & 240,5 & 290,364 & 670 & 4 & 0,6 & 1161,5 & 2 & 0,3 & 580,7 & 0 & 0,0 & 0,0 & 0 & 0,0 & 0,0 \\
\hline 26 & 250,5 & 144,557 & 741 & 2 & 0,3 & 289,1 & 1 & 0,1 & 144,6 & 0 & 0,0 & 0,0 & 0 & 0,0 & 0,0 \\
\hline 27 & 260,5 & 162,655 & 687 & 5 & 0,7 & 813,3 & 1 & 0,1 & 162,7 & 1 & 0,1 & 162,7 & 1 & 0,1 & 162,7 \\
\hline 28 & 271,5 & 332,833 & 761 & 3 & 0,4 & 998,5 & 1 & 0,1 & 332,8 & 0 & 0,0 & 0,0 & 1 & 0,1 & 332,8 \\
\hline 29 & 280,5 & 130,075 & 456 & 2 & 0,4 & 260,1 & 4 & 0,9 & 520,3 & 0 & 0,0 & 0,0 & 0 & 0,0 & 0,0 \\
\hline 30 & 290,5 & 473,217 & 0,0 & 0,0 & 0,0 & 0,0 & 0,0 & 0,0 & 0,0 & 0,0 & 0,0 & 0,0 & 0,0 & 0,0 & 0,0 \\
\hline 31 & 314,5 & 334,253 & 0,0 & 0,0 & 0,0 & 0,0 & 0,0 & 0,0 & 0,0 & 0,0 & 0,0 & 0,0 & 0,0 & 0,0 & 0,0 \\
\hline 32 & 345,5 & 612,398 & 0,0 & 0,0 & 0,0 & 0,0 & 0,0 & 0,0 & 0,0 & 0,0 & 0,0 & 0,0 & 0,0 & 0,0 & 0,0 \\
\hline
\end{tabular}


TABELA 3.3: Qualificação e quantificação dos tipos polínicos da Lagoa Bonita, DF

\begin{tabular}{|c|c|c|c|c|c|c|c|c|c|c|c|c|c|c|c|}
\hline \multirow{2}{*}{ NIVEL } & \multirow{2}{*}{$\begin{array}{l}\text { PROF. } \\
(\mathrm{cm})\end{array}$} & \multirow[b]{2}{*}{ B } & \multirow{2}{*}{ NTG } & \multicolumn{3}{|c|}{ Tipo Gramineae - 1005} & \multicolumn{3}{|c|}{ Tipo Compositae-A - 1029} & \multicolumn{3}{|c|}{ Tipo Acalypha - 1041} & \multicolumn{3}{|c|}{ Tipo Eriocaulaceae - 1006} \\
\hline & & & & $N^{\circ}$ Grắos & $\mathbf{P}(\%)$ & c & No Grăos & $P(\%)$ & C & NoGrás & $P(\%)$ & C & No Grăos & $P(\%)$ & C \\
\hline S1 & & & & & & & & & & & & & & & \\
\hline 1 & 5,5 & 45,1223 & 922 & 436 & 47,3 & 19673,3 & 5 & 0,5 & 225,6 & 42 & 4,6 & 1895,1 & 45 & 4,9 & 2030,5 \\
\hline 2 & 10,5 & 119,28 & 778 & 261 & 33,5 & 31132,2 & 9 & 1,2 & 1073,5 & 77 & 9,9 & 9184,6 & 50 & 6,4 & 5964,0 \\
\hline 3 & 20,5 & 69,303 & 877 & 368 & 42,0 & 25503,5 & 6 & 0,7 & 415,8 & 57 & 6,5 & 3950,3 & 25 & 2,9 & 1732,6 \\
\hline 4 & 30,5 & 60,8859 & 962 & 463 & 48,1 & 28190,2 & 8 & 0,8 & 487,1 & 39 & 4,1 & 2374,6 & 17 & 1,8 & 1035,1 \\
\hline 5 & 40,5 & 59,0672 & 903 & 452 & 50,1 & 26698,4 & 10 & 1,1 & 590,7 & 46 & 5,1 & 2717,1 & 2 & 0,2 & 118,1 \\
\hline 6 & 51,5 & 62,4266 & 930 & 530 & 57,0 & 33086,1 & 8 & 0,9 & 499,4 & $\overline{22}$ & 2,4 & 1373,4 & 2 & 0,2 & 124,9 \\
\hline 7 & 61,5 & 144,582 & 520 & 251 & 48,3 & 36290,2 & 5 & 1,0 & 722,9 & 48 & 9,2 & 6940,0 & $\overline{0}$ & 0,0 & 0,0 \\
\hline 8 & 70,5 & 39,9528 & 744 & 373 & 50,1 & 14902,4 & 11 & 1,5 & 439,5 & 69 & 9,3 & 2756,7 & 0 & 0,0 & 0,0 \\
\hline 9 & 80,5 & 95,5277 & 871 & 480 & 55,1 & 45853,3 & 5 & 0,6 & 477,6 & 14 & 1,6 & 1337,4 & 67 & 7,7 & 6400,4 \\
\hline 10 & 90,5 & 30,138 & 341 & 203 & 59,5 & 6118,0 & 6 & 1,8 & 180,8 & 12 & 3,5 & 361,7 & 2 & 0,6 & 60,3 \\
\hline 11 & 101,5 & 61,5586 & 702 & 336 & 47,9 & 20683,7 & 21 & 3,0 & 1292,7 & 17 & 2,4 & 1046,5 & 7 & 1,0 & 430,9 \\
\hline 12 & 110,5 & 89,4261 & 537 & 221 & 41,2 & 19763,2 & 11 & 2,0 & 983,7 & 17 & 3,2 & 1520,2 & 1 & 0,2 & 89,4 \\
\hline 13 & 120,5 & 114,361 & 510 & 211 & 41,4 & 24130,1 & 15 & 2,9 & 1715,4 & 8 & 1,6 & 914,9 & 5 & 1,0 & 571,8 \\
\hline 14 & 131,5 & 133,444 & 488 & 199 & 40,8 & 26555,3 & $\overline{21}$ & 4,3 & 2802,3 & 9 & 1,8 & 1201,0 & 5 & 1,0 & 667,2 \\
\hline 15 & 140,5 & 194,534 & 541 & 289 & 53,4 & 56220,5 & 34 & 6,3 & 6614,2 & 5 & 0,9 & 972,7 & 4 & 0,7 & 778,1 \\
\hline 16 & 150,5 & 254,669 & 858 & 505 & 58,9 & 128607,7 & 34 & 4,0 & 8658,7 & 1 & 0,1 & 254,7 & 8 & 0,9 & 2037,3 \\
\hline 17 & 160,5 & 336,829 & 947 & 508 & 53,6 & 171108,9 & 20 & 2,1 & 6736,6 & 5 & 0,5 & 1684,1 & 27 & 2,9 & 9094,4 \\
\hline 18 & 170,5 & 405,477 & 1000 & 469 & 46,9 & 190168,9 & 34 & 3,4 & 13786,2 & 2 & 0,2 & 811,0 & 27 & 2,7 & 10947,9 \\
\hline 19 & 180,5 & 341,247 & 1119 & 505 & 45,1 & 172329,9 & 38 & 3,4 & 12967,4 & 2 & 0,2 & 682,5 & 18 & 1,6 & 6142,5 \\
\hline 20 & 190,5 & 276,772 & 1239 & 563 & 45,4 & 155822,6 & 46 & 3,7 & 12731,5 & 2 & 0,2 & 553,5 & 30 & 2,4 & 8303,2 \\
\hline 21 & 201,5 & 176,707 & 829 & 401 & 48,4 & 70859,5 & 16 & 1,9 & 2827,3 & 1 & 0,1 & 176,7 & 24 & 2,9 & 4241,0 \\
\hline 22 & 210,5 & 210,849 & 859 & 467 & 54,4 & 98466,6 & 32 & 3,7 & 6747,2 & 1 & 0,1 & 210,8 & 21 & 2,4 & 4427,8 \\
\hline 23 & 220,5 & 218,176 & 765 & 300 & 39,2 & 65452,8 & 16 & 2,1 & 3490,8 & 3 & 0,4 & 654,5 & 26 & 3,4 & 5672,6 \\
\hline 24 & 230,5 & 216,228 & 715 & 249 & 34,8 & 53840,8 & 17 & 2,4 & 3675,9 & 4 & 0,6 & 864,9 & 11 & 1,5 & 2378,5 \\
\hline 25 & 240,5 & 290,364 & 670 & 196 & 29,3 & 56911,2 & 19 & 2,8 & 5516,9 & 3 & 0,4 & 871,1 & 31 & 4,6 & $9,001,3$ \\
\hline 26 & 250,5 & 144,557 & 741 & 266 & 35,9 & 38452,2 & 13 & 1,8 & 1879,2 & 7 & 0,9 & 1011,9 & 26 & 3,5 & 3758,5 \\
\hline 27 & 260,5 & 162,655 & 687 & 187 & 27,2 & 30416,5 & 16 & 2,3 & 2602,5 & 7 & 1,0 & 1138,6 & 30 & 4,4 & 4879,7 \\
\hline 28 & 271,5 & 332,833 & 761 & 204 & 26,8 & 67897,9 & 28 & 3,7 & 9319,3 & 7 & 0,9 & 2329,8 & 26 & 3,4 & 8653,7 \\
\hline 29 & 280,5 & 130,075 & 456 & 122 & 26,8 & 15869,1 & 17 & 3,7 & 2211,3 & 0 & 0,0 & 0,0 & 13 & 2,9 & 1691,0 \\
\hline 30 & 290,5 & 473,217 & 0,0 & 0,0 & 0,0 & 0,0 & 0,0 & 0,0 & 0,0 & 0,0 & 0,0 & 0,0 & 0,0 & 0,0 & 0,0 \\
\hline 31 & 314,5 & 334,253 & 0,0 & 0,0 & 0,0 & 0,0 & 0,0 & 0,0 & 0,0 & 0,0 & 0,0 & 0,0 & 0,0 & 0,0 & 0,0 \\
\hline 32 & 345,5 & 612,398 & 0,0 & 0,0 & 0,0 & 0,0 & 0,0 & 0,0 & 0,0 & 0,0 & 0,0 & 0,0 & 0,0 & 0,0 & 0,0 \\
\hline
\end{tabular}


TABELA 3.3: Qualificação e quantificação dos tipos polínicos da Lagoa Bonita, DF

continuação

\begin{tabular}{|c|c|c|c|c|c|c|c|c|c|c|c|c|c|c|c|}
\hline \multirow{2}{*}{ NIVEL } & \multirow{2}{*}{$\begin{array}{l}\text { PROF. } \\
(\mathrm{cm})\end{array}$} & \multirow{2}{*}{ B } & \multirow{2}{*}{ NTO } & \multicolumn{3}{|c|}{ Tipo Arrabidaea - 1092} & \multicolumn{3}{|c|}{ Tipo Couepia - 1039} & \multicolumn{3}{|c|}{ Tipo Melastomataceae - 1030} & \multicolumn{3}{|c|}{ Tipo Myrtaceae - 1028} \\
\hline & & & & $\mathrm{N}^{0}$ Grắos & $P(\%)$ & C & No Grăos & $P(\%)$ & C & ND Gráos & $P(\%)$ & C & $N^{0}$ Crăos & $\mathrm{P}(\%)$ & C \\
\hline s1 & & & & & & & & & & & & & & & \\
\hline 1 & 5,5 & 45,1223 & 922 & 0 & 0,0 & 0,0 & 0 & 0,0 & 0,0 & 14 & 1,5 & 631,7 & 6 & 0,7 & 270,7 \\
\hline 2 & 10,5 & 119,28 & 778 & 0 & 0,0 & 0,0 & 0 & 0,0 & 0,0 & 20 & 2,6 & 2385,6 & 8 & 1,0 & $\overline{954,2}$ \\
\hline 3 & 20,5 & 69,303 & 877 & 1 & 0,1 & 69,3 & 0 & 0,0 & 0,0 & 23 & 2,6 & 1594,0 & 9 & 1,0 & 623,7 \\
\hline 4 & 30,5 & 60,8859 & 962 & 0 & 0,0 & 0,0 & 0 & 0,0 & 0,0 & 20 & 2,1 & 1217,7 & 9 & 0,9 & 548,0 \\
\hline 5 & 40,5 & 59,0672 & 903 & 0 & 0,0 & 0,0 & 0 & 0,0 & 0,0 & 7 & 0,8 & 413,5 & 7 & 0,8 & 413,5 \\
\hline 8 & 51,5 & 62,4266 & 930 & 0 & 0,0 & 0,0 & $\overline{0}$ & 0,0 & 0,0 & 25 & 2,7 & 1560,7 & 5 & 0,5 & 312,1 \\
\hline 7 & 61,5 & 144,582 & 520 & 1 & 0,2 & 144,6 & $\overline{0}$ & 0,0 & 0,0 & 9 & 1,7 & 1301,2 & 6 & 1,2 & 867,5 \\
\hline 8 & 70,5 & 39,9528 & 744 & 0 & 0,0 & 0,0 & 0 & 0,0 & 0,0 & 8 & 1,1 & 319,6 & 9 & 1,2 & 359,6 \\
\hline 9 & 80,5 & 95,5277 & 871 & 0 & 0,0 & 0,0 & 0 & 0,0 & 0,0 & 21 & 2,4 & 2006,1 & 8 & 0,9 & 764,2 \\
\hline 10 & 90,5 & 30,138 & 341 & 0 & 0,0 & 0,0 & 0 & 0,0 & 0,0 & 5 & 1,5 & 150,7 & 1 & 0,3 & 30,1 \\
\hline 11 & 101,5 & 61,5586 & 702 & 0 & 0,0 & 0,0 & 0 & 0,0 & 0,0 & 25 & 3,6 & 1539,0 & 31 & 4,4 & 1908,3 \\
\hline 12 & 110,5 & 89,4261 & 537 & 0 & 0,0 & 0,0 & 0 & 0,0 & 0,0 & 27 & 5,0 & 2414,5 & 24 & 4,5 & 2146,2 \\
\hline 13 & 120,5 & 114,361 & 510 & 0 & 0,0 & 0,0 & 0 & 0,0 & 0,0 & 30 & 5,9 & 3430,8 & 24 & 4,7 & 2744,7 \\
\hline 14 & 131,5 & 133,444 & 488 & 0 & 0,0 & 0,0 & 0 & 0,0 & 0,0 & 18 & 3,7 & 2402,0 & 8 & 1,6 & 1067,5 \\
\hline 15 & 140,5 & 194,534 & 541 & 0 & 0,0 & 0,0 & 0 & 0,0 & 0,0 & 15 & 2,8 & 2918,0 & 3 & 0,6 & 583,6 \\
\hline 16 & 150,5 & 254,669 & 858 & 0 & 0,0 & 0,0 & 0 & 0,0 & 0,0 & 21 & 2,4 & 5348,0 & 6 & 0,7 & 1528,0 \\
\hline 17 & 160,5 & 336,829 & 947 & 0 & 0,0 & 0,0 & 0 & 0,0 & 0,0 & 21 & 2,2 & 7073,4 & 6 & 0,6 & 2021,0 \\
\hline 18 & 170,5 & 405,477 & 1000 & 0 & 0,0 & 0,0 & 0 & 0,0 & 0,0 & 27 & 2,7 & 10947,9 & 5 & 0,5 & 2027,4 \\
\hline 19 & 180,5 & 341,247 & 1119 & 0 & 0,0 & 0,0 & 0 & 0,0 & 0,0 & 22 & 2,0 & 7507,4 & 17 & 1,5 & 5801,2 \\
\hline 20 & 190,5 & 276,772 & 1239 & 0 & 0,0 & 0,0 & 0 & 0,0 & 0,0 & 35 & 2,8 & 9687,0 & 8 & 0,6 & 2214,2 \\
\hline 21 & 201,5 & 176,707 & 829 & 0 & 0,0 & 0,0 & 0 & 0,0 & 0,0 & 26 & 3,1 & 4594,4 & 11 & 1,3 & 1943,8 \\
\hline 22 & 210,5 & 210,849 & 859 & 0 & 0,0 & 0,0 & 0 & 0.0 & 0,0 & 16 & 1,9 & 3373,6 & 6 & 0,7 & 1265,1 \\
\hline$\overline{23}$ & 220,5 & 218,176 & 765 & 0 & 0,0 & 0,0 & 0 & $0, \overline{0}$ & 0,0 & 25 & 3,3 & 5454,4 & 11 & 1,4 & 2399,9 \\
\hline 24 & 230,5 & 216,228 & 715 & 0 & 0,0 & 0,0 & 0 & 0,0 & 0,0 & 32 & 4,5 & 6919,3 & 9 & 1,3 & 1946,1 \\
\hline 25 & 240,5 & 290,364 & 670 & 0 & 0,0 & 0,0 & 0 & 0,0 & 0,0 & 15 & 2,2 & 4355,5 & 7 & 1,0 & 2032,5 \\
\hline 26 & 250,5 & 144,557 & 741 & 0 & 0,0 & 0,0 & 0 & 0,0 & 0,0 & 29 & 3,9 & 4192,2 & 18 & 2,4 & 2602,0 \\
\hline 27 & 260,5 & 162,655 & 687 & 0 & 0,0 & 0,0 & 0 & 0,0 & 0,0 & 33 & 4,8 & 5367,6 & 14 & 2,0 & 2277,2 \\
\hline 28 & 271,5 & 332,833 & 761 & 0 & 0,0 & 0,0 & 0 & 0,0 & 0,0 & 36 & 4,7 & 11982,0 & 11 & 1,4 & 3661,2 \\
\hline 29 & 280,5 & 130,075 & 456 & 0 & 0,0 & 0,0 & 1 & 0,2 & 130,1 & 11 & 2,4 & 1430,8 & 7 & 1,5 & 910,5 \\
\hline 30 & 290,5 & 473,217 & 0,0 & 0,0 & 0,0 & 0,0 & 0,0 & 0,0 & 0,0 & 0,0 & 0,0 & 0,0 & 0,0 & 0,0 & 0,0 \\
\hline 31 & 314,5 & 334,253 & 0,0 & 0,0 & 0,0 & 0,0 & 0,0 & 0,0 & 0,0 & 0,0 & 0,0 & 0,0 & 0,0 & 0,0 & 0,0 \\
\hline 32 & 345,5 & 612,398 & 0,0 & 0,0 & 0,0 & 0,0 & 0,0 & 0,0 & 0,0 & 0,0 & 0,0 & 0,0 & 0,0 & 0,0 & 0,0 \\
\hline
\end{tabular}


TABELA 3.3: Qualificaçăo e quantificaçăo dos tipos polínicos da Lagoa Bonita, DF

continuação

\begin{tabular}{|c|c|c|c|c|c|c|c|c|c|c|c|c|c|c|c|}
\hline \multirow{2}{*}{ NIVEL. } & \multirow{2}{*}{$\begin{array}{l}\text { PROF. } \\
(\mathrm{cm})\end{array}$} & \multirow{2}{*}{ B } & \multirow{2}{*}{ NTG } & \multicolumn{3}{|c|}{ Tipo Cuphea-A - 1044} & \multicolumn{3}{|c|}{ Tipo Smilax-A - 1021} & \multicolumn{3}{|c|}{ Tipo Tragia - 1061} & \multicolumn{3}{|c|}{ Tipo Caryophyllaceae - 1134} \\
\hline & & & & N & $P(\%)$ & C & No Grắos & $P(\%)$ & C & No Grăos & $P(\%)$ & C & 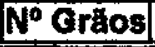 & $P(\%)$ & C \\
\hline S1 & & & & & & & & & & & & & & & \\
\hline 1 & 5,5 & 45,1223 & 922 & 2 & $\overline{0,2}$ & 90,2 & 4 & 0,4 & 180,5 & 2 & 0,2 & 90,2 & 0 & 0,0 & 0,0 \\
\hline 2 & 10,5 & 119,28 & 778 & 2 & 0,3 & 238,6 & 20 & 2,6 & 2385,6 & 3 & 0,4 & 357,8 & 0 & 0,0 & 0,0 \\
\hline 3 & 20,5 & 69,303 & 877 & 1 & 0,1 & 69,3 & 16 & 1,8 & 1108,8 & $\overline{2}$ & $\overline{0,2}$ & $\overline{138,6}$ & 0 & 0,0 & 0,0 \\
\hline 4 & 30,5 & 60,8859 & 962 & 0 & 0,0 & 0,0 & 11 & 1,1 & 669,7 & 0 & 0,0 & 0,0 & 0 & 0,0 & 0,0 \\
\hline 5 & 40,5 & 59,0672 & 903 & 0 & 0,0 & 0,0 & 3 & 0,3 & 177,2 & $\overline{5}$ & 0,6 & 295,3 & 1 & 0,1 & 59,1 \\
\hline 6 & 51,5 & 62,4266 & 930 & 1 & 0,1 & 62,4 & 9 & 1,0 & 561,8 & 5 & 0,5 & 312,1 & 0 & 0,0 & 0,0 \\
\hline 7 & 61,5 & 144,582 & 520 & 0 & 0,0 & 0,0 & 0 & 0,0 & 0,0 & 0 & 0,0 & 0,0 & 0 & 0,0 & 0,0 \\
\hline 8 & 70,5 & 39,9528 & 744 & 0 & 0,0 & 0,0 & 0 & 0,0 & 0,0 & 0 & 0,0 & 0,0 & 2 & 0,3 & 79,9 \\
\hline 9 & 80,5 & 95,5277 & 871 & 0 & 0,0 & 0,0 & 0 & 0,0 & 0,0 & 0 & 0,0 & 0,0 & 0 & 0,0 & 0,0 \\
\hline 10 & 90,5 & 30,138 & 341 & 0 & 0,0 & 0,0 & 1 & 0,3 & 30,1 & 0 & 0,0 & 0,0 & 0 & 0,0 & 0,0 \\
\hline 11 & 101,5 & 61,5586 & 702 & 0 & 0,0 & 0,0 & 0 & 0,0 & 0,0 & 1 & 0,1 & 61,6 & 0 & 0,0 & 0,0 \\
\hline 12 & 110,5 & 89,4261 & 537 & 1 & 0,2 & 89,4 & 5 & 0,9 & 447,1 & $\overline{0}$ & 0,0 & 0,0 & 0 & 0,0 & 0,0 \\
\hline 13 & 120,5 & 114,361 & 510 & 1 & 0,2 & 114,4 & 2 & 0,4 & 228,7 & 0 & 0,0 & 0,0 & 2 & 0,4 & 228,7 \\
\hline 14 & 131,5 & 133,444 & 488 & 0 & 0,0 & 0,0 & 3 & 0,6 & 400,3 & 2 & 0,4 & 266,9 & 0 & 0,0 & 0,0 \\
\hline 15 & 140,5 & 194,534 & 541 & 0 & 0,0 & 0,0 & 1 & 0,2 & 194,5 & 0 & 0,0 & 0,0 & 0 & 0,0 & 0,0 \\
\hline 16 & 150,5 & 254,669 & 858 & 1 & 0,1 & 254,7 & 2 & 0,2 & 509,3 & 1 & 0,1 & 254,7 & 1 & 0,1 & 254,7 \\
\hline 17 & 160,5 & 336,829 & 947 & 6 & 0,6 & 2021,0 & 4 & 0,4 & 1347,3 & 1 & 0,1 & 336,8 & 0 & 0,0 & 0,0 \\
\hline 18 & 170,5 & 405,477 & 1000 & 5 & 0,5 & 2027,4 & 8 & 0,8 & 3243,8 & 0 & 0,0 & 0,0 & 2 & 0,2 & 811,0 \\
\hline 19 & 180,5 & 341,247 & 1119 & 9 & 0,8 & 3071,2 & 13 & 1,2 & 4436,2 & 0 & 0,0 & 0,0 & 1 & 0,1 & 341,2 \\
\hline 20 & 190,5 & 276,772 & 1239 & 19 & 1,5 & 5258,7 & 5 & 0,4 & 1383,9 & 0 & 0,0 & 0,0 & 0 & 0,0 & 0,0 \\
\hline 21 & 201,5 & 176,707 & 829 & 7 & 0,8 & 1236,9 & 2 & 0,2 & 353,4 & 0 & 0,0 & 0,0 & 0 & 0,0 & 0,0 \\
\hline 22 & 210,5 & 210,849 & 859 & 2 & 0,2 & 421,7 & 3 & 0,3 & 632,5 & 0 & 0,0 & 0,0 & 4 & 0,5 & 843,4 \\
\hline 23 & 220,5 & 218,176 & 765 & 3 & 0,4 & 654,5 & 3 & 0,4 & 654,5 & 0 & 0,0 & 0,0 & 2 & 0,3 & 436,4 \\
\hline 24 & 230,5 & 216,228 & 715 & 0 & 0,0 & 0,0 & 1 & 0,1 & 216,2 & 0 & 0,0 & 0,0 & 1 & 0,1 & 216,2 \\
\hline 25 & 240,5 & 290,364 & 670 & 0 & 0,0 & 0,0 & 3 & 0,4 & 871,1 & 0 & 0,0 & 0,0 & 1 & 0,1 & 290,4 \\
\hline 26 & 250,5 & 144,557 & 741 & 1 & 0,1 & 144,6 & 0 & 0,0 & 0,0 & $\overline{0}$ & 0,0 & 0,0 & 0 & 0,0 & 0,0 \\
\hline 27 & 260,5 & 162,655 & 687 & 0 & 0,0 & 0,0 & 2 & 0,3 & 325,3 & 0 & 0,0 & 0,0 & 0 & 0,0 & 0,0 \\
\hline 28 & 271,5 & 332,833 & 761 & 0 & 0,0 & 0,0 & 1 & 0,1 & 332,8 & 0 & 0,0 & 0,0 & 2 & 0,3 & 665,7 \\
\hline 29 & 280,5 & 130,075 & 456 & 0 & 0,0 & 0,0 & 3 & 0,7 & 390,2 & 0 & 0,0 & 0,0 & 0 & 0,0 & 0,0 \\
\hline 30 & 290,5 & 473,217 & 0,0 & 0,0 & 0,0 & 0,0 & 0,0 & 0,0 & 0,0 & 0,0 & 0,0 & 0,0 & 0,0 & 0,0 & 0,0 \\
\hline 31 & 314,5 & 334,253 & 0,0 & 0,0 & 0,0 & 0,0 & 0,0 & 0,0 & 0,0 & 0,0 & 0,0 & 0,0 & 0,0 & 0,0 & 0,0 \\
\hline 32 & 345,5 & 612,398 & 0,0 & 0,0 & 0,0 & 0,0 & 0,0 & 0,0 & 0,0 & 0,0 & 0,0 & 0,0 & 0,0 & 0,0 & 0,0 \\
\hline
\end{tabular}


TABELA 3.3: Qualificação e quantificação dos tipos polínicos da Lagoa Bonita, DF

\begin{tabular}{|c|c|c|c|c|c|c|c|c|c|c|c|c|c|c|c|}
\hline \multirow{2}{*}{ NIVEL. } & \multirow{2}{*}{$\begin{array}{c}\text { PROF. } \\
\text { (cm) }\end{array}$} & \multirow{2}{*}{ B } & \multirow{2}{*}{ NTG } & \multicolumn{3}{|c|}{ Tipo Bernardia - 1011} & \multicolumn{3}{|c|}{ Tipo Maprounea-C - 1142} & \multicolumn{3}{|c|}{ Tipo Hyptis - 1090} & \multicolumn{3}{|c|}{ Tipo Bredemeyera - 1088} \\
\hline & & & & No Grăos & $P(\%)$ & C & $N^{\circ}$ Grăos & $\mathbf{P}(\%)$ & $\mathbf{C}$ & No Grăos & $P(\%)$ & $\bar{c}$ & No Grăos & $P(\%)$ & $\mathbf{C}$ \\
\hline \multicolumn{16}{|l|}{ S1 } \\
\hline 1 & 5,5 & 45,1223 & 922 & 5 & 0,5 & 225,6 & 3 & 0,3 & 135,4 & 3 & 0,3 & 135,4 & 0 & 0,0 & 0,0 \\
\hline 2 & 10,5 & 119,28 & 778 & 10 & 1,3 & 1192,8 & 0 & 0,0 & 0,0 & 3 & 0,4 & 357,8 & 0 & 0,0 & 0,0 \\
\hline 3 & 20,5 & 69,303 & 877 & 4 & 0,5 & 277,2 & 1 & 0,1 & 69,3 & 3 & 0,3 & 207,9 & 1 & 0,1 & 69,3 \\
\hline 4 & 30,5 & 60,8859 & 962 & 14 & 1,5 & 852,4 & 4 & 0,4 & 243,5 & 2 & 0,2 & 121,8 & 1 & 0,1 & 60,9 \\
\hline 5 & 40,5 & 59,0672 & 903 & 6 & 0,7 & 354,4 & 4 & 0,4 & 236,3 & 1 & 0,1 & 59,1 & 1 & 0,1 & 59,1 \\
\hline 6 & 51,5 & 62,4266 & 930 & 1 & 0,1 & 62,4 & 2 & 0,2 & 124,9 & 1 & 0,1 & 62,4 & 0 & 0,0 & 0,0 \\
\hline 7 & 61,5 & 144,582 & 520 & 0 & 0,0 & 0,0 & 0 & 0,0 & 0,0 & 2 & 0,4 & 289,2 & 1 & $0, \overline{2}$ & 144,6 \\
\hline 8 & 70,5 & 39,9528 & 744 & 4 & 0,5 & 159,8 & 0 & 0,0 & 0,0 & 2 & 0,3 & 79,9 & 1 & 0,1 & 40,0 \\
\hline 9 & 80,5 & 95,5277 & 871 & 14 & 1,6 & 1337,4 & 1 & 0,1 & 95,5 & 2 & 0,2 & 191,1 & 0 & 0,0 & 0,0 \\
\hline 10 & 90,5 & 30,138 & 341 & 8 & 2,3 & 241,1 & $\overline{0}$ & 0,0 & 0,0 & 0 & 0,0 & 0,0 & 0 & 0,0 & 0,0 \\
\hline 11 & 101,5 & 61,5586 & 702 & 2 & 0,3 & 123,1 & 1 & 0,1 & 61,6 & 1 & 0,1 & 61,6 & 0 & 0,0 & 0,0 \\
\hline 12 & 110,5 & 89,4261 & 537 & 4 & 0,7 & 357,7 & 3 & 0,6 & 268,3 & 2 & 0,4 & 178,9 & 0 & 0,0 & 0,0 \\
\hline 13 & 120,5 & 114,361 & 510 & 2 & 0,4 & 228,7 & 1 & 0,2 & 114,4 & 0 & 0,0 & 0,0 & 1 & 0,2 & 114,4 \\
\hline 14 & 131,5 & 133,444 & 488 & 0 & 0,0 & 0,0 & 5 & 1,0 & 667,2 & 0 & 0,0 & 0,0 & 0 & 0,0 & 0,0 \\
\hline 15 & 140,5 & 194,534 & 541 & 0 & 0,0 & 0,0 & 6 & 1,1 & 1167,2 & 0 & 0,0 & 0,0 & 0 & 0,0 & 0,0 \\
\hline 16 & 150,5 & 254,669 & 858 & 1 & 0,1 & 254,7 & 4 & 0,5 & 1018,7 & 0 & 0,0 & 0,0 & 4 & 0,5 & 1018,7 \\
\hline 17 & 160,5 & 336,829 & 947 & 4 & 0,4 & 1347,3 & 6 & 0,6 & 2021,0 & 1 & 0,1 & 336,8 & 6 & 0,6 & 2021,0 \\
\hline 18 & 170,5 & 405,477 & 1000 & 0 & 0,0 & 0,0 & 2 & 0,2 & 811,0 & 0 & 0,0 & 0,0 & 6 & 0,6 & 2432,9 \\
\hline 19 & 180,5 & 341,247 & 1119 & 0 & 0,0 & 0,0 & 2 & 0,2 & 682,5 & 0 & 0,0 & 0,0 & 5 & 0,4 & 1706,2 \\
\hline 20 & 190,5 & 276,772 & 1239 & 3 & 0,2 & 830,3 & 3 & 0,2 & 830,3 & 1 & 0,1 & 276,8 & 9 & 0,7 & 2490,9 \\
\hline 21 & 201,5 & 176,707 & 829 & 1 & 0,1 & 176,7 & 2 & 0,2 & 353,4 & 0 & 0,0 & 0,0 & 2 & 0,2 & 353,4 \\
\hline 22 & 210,5 & 210,849 & 859 & 0 & 0,0 & 0,0 & 2 & 0,2 & 421,7 & 2 & 0,2 & 421,7 & 3 & 0,3 & 632,5 \\
\hline 23 & 220,5 & 218,176 & 765 & 0 & 0,0 & 0,0 & 3 & 0,4 & 654,5 & 0 & 0,0 & 0,0 & 10 & 1,3 & 2181,8 \\
\hline 24 & 230,5 & 216,228 & 715 & 0 & 0,0 & 0,0 & 10 & 1,4 & 2162,3 & 0 & 0,0 & 0,0 & 3 & 0,4 & 648,7 \\
\hline 25 & 240,5 & 290,364 & 670 & 1 & 0,1 & 290,4 & 3 & 0,4 & 871,1 & 0 & 0,0 & 0,0 & 3 & 0,4 & 871,1 \\
\hline 26 & 250,5 & 144,557 & 741 & 0 & 0,0 & 0,0 & 2 & 0,3 & 289,1 & 0 & 0,0 & 0,0 & 5 & 0,7 & 722,8 \\
\hline 27 & 260,5 & 162,655 & 687 & 7 & 1,0 & 1138,6 & 0 & 0,0 & 0,0 & 1 & 0,1 & 162,7 & 3 & 0,4 & 488,0 \\
\hline 28 & 271,5 & 332,833 & 761 & 3 & 0,4 & 998,5 & 0 & 0,0 & 0,0 & 0 & 0,0 & 0,0 & 2 & 0,3 & 665,7 \\
\hline 29 & 280,5 & 130,075 & 456 & 1 & 0,2 & 130,1 & 0 & 0,0 & 0,0 & 0 & 0,0 & 0,0 & 1 & 0,2 & 130,1 \\
\hline 30 & 290,5 & 473,217 & 0,0 & 0,0 & 0,0 & 0,0 & 0,0 & 0,0 & 0,0 & 0,0 & 0,0 & 0,0 & 0,0 & 0,0 & 0,0 \\
\hline 31 & 314,5 & 334,253 & 0,0 & 0,0 & 0,0 & 0,0 & 0,0 & 0,0 & 0,0 & 0,0 & 0,0 & 0,0 & 0,0 & 0,0 & 0,0 \\
\hline 32 & 345,5 & 612,398 & 0,0 & 0,0 & 0,0 & 0,0 & 0,0 & 0,0 & 0,0 & 0,0 & 0,0 & 0,0 & 0,0 & 0,0 & 0,0 \\
\hline
\end{tabular}


TABELA 3.3: Qualificação e quantificação dos tipos polínicos da Lagoa Bonita, DF

continuaçăo

\begin{tabular}{|c|c|c|c|c|c|c|c|c|c|c|c|c|c|c|c|}
\hline \multirow{2}{*}{ NIVEL } & \multirow{2}{*}{$\begin{array}{l}\text { PROF. } \\
\text { (cm) }\end{array}$} & \multirow[t]{2}{*}{ B } & \multirow{2}{*}{ NTE } & \multicolumn{3}{|c|}{ Tipo Cassia - 1177} & \multicolumn{3}{|c|}{ Tipo Altemanthera - 1037} & \multicolumn{3}{|c|}{ Tipo Borreria-A-1133 } & \multicolumn{3}{|c|}{ Tipo Richardsonia - 1096} \\
\hline & & & & No Grăos & $\mathbf{P}(\%)$ & C & $\mathrm{N}^{\circ}$ Crăos & $P(\%)$ & C & No Grắos & $\mathbf{P}(\%)$ & C & $\mathrm{N}^{\circ}$ Grăos & $P(\%)$ & C \\
\hline \multicolumn{16}{|l|}{ s1 } \\
\hline 1 & 5,5 & 45,1223 & 922 & 0 & 0,0 & 0,0 & 5 & 0,5 & 225,6 & 0 & 0,0 & 0,0 & 0 & 0,0 & 0,0 \\
\hline 2 & 10,5 & 119,28 & 778 & 0 & 0,0 & 0,0 & 1 & 0,1 & 119,3 & $\frac{2}{2}$ & 0,3 & 238,6 & 0 & 0,0 & 0,0 \\
\hline 3 & 20,5 & 69,303 & 877 & 0 & 0,0 & 0,0 & 1 & 0,1 & 69,3 & 1 & 0,1 & 69,3 & 0 & 0,0 & 0,0 \\
\hline 4 & 30,5 & 60,8859 & 962 & 0 & 0,0 & 0,0 & 0 & 0,0 & 0,0 & 0 & 0,0 & 0,0 & 0 & 0,0 & 0,0 \\
\hline 5 & 40,5 & 59,0672 & 903 & 0 & 0,0 & 0,0 & 3 & 0,3 & 177,2 & 3 & 0,3 & 177,2 & 3 & 0,3 & 177,2 \\
\hline 6 & 51,5 & 62,4266 & 930 & 0 & 0,0 & 0,0 & 1 & 0,1 & 62,4 & 2 & 0,2 & 124,9 & 1 & 0,1 & 62,4 \\
\hline 7 & 61,5 & $144,5 \overline{8}$ & 520 & 0 & 0,0 & 0,0 & 0 & 0,0 & 0,0 & 1 & 0,2 & 144,6 & 0 & 0,0 & 0,0 \\
\hline 8 & 70,5 & 39,9528 & 744 & 0 & 0,0 & 0,0 & 2 & 0,3 & 79,9 & 0 & 0,0 & 0,0 & 0 & 0,0 & 0,0 \\
\hline 9 & 80,5 & 95,5277 & 871 & 0 & 0,0 & 0,0 & 1 & 0,1 & 95,5 & 1 & 0,1 & 95,5 & 0 & 0,0 & 0,0 \\
\hline 10 & 90,5 & 30,138 & 341 & 0 & 0,0 & 0,0 & 0 & 0,0 & 0,0 & 0 & 0,0 & 0,0 & 0 & 0,0 & 0,0 \\
\hline 11 & 101,5 & 64,5586 & 702 & 0 & 0,0 & 0,0 & 3 & 0,4 & 184,7 & 3 & 0,4 & 184,7 & 0 & 0,0 & 0,0 \\
\hline 12 & 110,5 & 89,4261 & 537 & 0 & 0,0 & 0,0 & 3 & 0,6 & 268,3 & 3 & 0,6 & 268,3 & o & 0,0 & 0,0 \\
\hline 13 & 120,5 & 114,361 & 510 & 0 & 0,0 & 0,0 & 1 & 0,2 & 114,4 & 1 & 0,2 & 114,4 & 1 & 0,2 & 114,4 \\
\hline 14 & 131,5 & 133,444 & 488 & 1 & 0,2 & 133,4 & 0 & 0,0 & 0,0 & 2 & 0,4 & 266,9 & 0 & 0,0 & 0,0 \\
\hline 15 & 140,5 & 194,534 & 541 & 0 & 0,0 & 0,0 & 0 & 0,0 & 0,0 & 0 & 0,0 & 0,0 & 0 & 0,0 & 0,0 \\
\hline 16 & 150,5 & 254,669 & 858 & 0 & 0,0 & 0,0 & 2 & 0,2 & 509,3 & 2 & 0,2 & 509,3 & 0 & 0,0 & 0,0 \\
\hline 17 & 160,5 & 336,829 & 947 & 0 & 0,0 & 0,0 & 4 & 0,4 & 1347,3 & 2 & 0,2 & 673,7 & 1 & 0,1 & 336,8 \\
\hline 18 & 170,5 & 405,477 & 1000 & 0 & 0,0 & 0,0 & 0 & 0,0 & 0,0 & 3 & 0,3 & 1216,4 & 1 & 0,1 & 405,5 \\
\hline 19 & 180,5 & 341,247 & 1119 & 0 & 0,0 & 0,0 & 0 & 0,0 & 0,0 & 2 & 0,2 & 682,5 & 2 & 0,2 & 682,5 \\
\hline 20 & 190,5 & 276,772 & 1239 & 4 & 0,3 & 1107,1 & 4 & 0,3 & 1107,1 & 2 & 0,2 & 553,5 & 0 & 0,0 & 0,0 \\
\hline 21 & 201,5 & 176,707 & 829 & 0 & 0,0 & 0,0 & 4 & 0,5 & 706,8 & 0 & 0,0 & 0,0 & 0 & 0,0 & 0,0 \\
\hline 22 & 210,5 & 210,849 & 859 & 0 & 0,0 & 0,0 & 3 & 0,3 & 632,5 & 1 & 0,1 & 210,8 & 0 & 0,0 & 0,0 \\
\hline 23 & 220,5 & 218,176 & 765 & 0 & 0,0 & 0,0 & 3 & 0,4 & 654,5 & 2 & 0,3 & 436,4 & 0 & 0,0 & 0,0 \\
\hline 24 & 230,5 & 216,228 & 715 & 0 & 0,0 & 0,0 & 6 & 0,8 & 1297,4 & 3 & 0,4 & 648,7 & 1 & 0,1 & 216,2 \\
\hline 25 & 240,5 & 290,364 & 670 & 0 & 0,0 & 0,0 & 14 & 2,1 & 4065,1 & 0 & 0,0 & 0,0 & 0 & 0,0 & 10,0 \\
\hline 26 & 250,5 & 144,557 & 741 & 0 & 0,0 & 0,0 & 7 & 0,9 & 1011,9 & 2 & 0,3 & 289,1 & 1 & 0,1 & 144,6 \\
\hline 27 & 260,5 & 162,655 & 687 & 0 & 0,0 & 0,0 & 3 & 0,4 & 488,0 & 2 & 0,3 & 325,3 & 0 & 0,0 & 0,0 \\
\hline 28 & 271,5 & 332,833 & 761 & 0 & 0,0 & 0,0 & 3 & 0,4 & 998,5 & 2 & 0,3 & 665,7 & 0 & 0,0 & 0,0 \\
\hline 29 & 280,5 & 130,075 & 456 & 1 & 0,2 & 130,1 & 4 & 0,9 & 520,3 & 0 & 0,0 & 0,0 & 0 & 0,0 & 0,0 \\
\hline 30 & 290,5 & 473,217 & 0,0 & 0,0 & 0,0 & 0,0 & 0,0 & 0,0 & 0,0 & 0,0 & 0,0 & 0,0 & 0,0 & 0,0 & 0,0 \\
\hline 31 & 314,5 & 334,253 & 0,0 & 0,0 & 0,0 & 0,0 & 0,0 & 0,0 & 0,0 & 0,0 & 0,0 & 0,0 & 0,0 & 0,0 & 0,0 \\
\hline 32 & 345,5 & 612,398 & 0,0 & 0,0 & 0,0 & 0,0 & 0,0 & 0,0 & 0,0 & 0,0 & 0,0 & 0,0 & 0,0 & 0,0 & 0,0 \\
\hline
\end{tabular}




\begin{tabular}{|c|c|c|c|c|c|c|c|c|c|c|c|c|c|c|c|}
\hline \multirow{2}{*}{ NIVEL } & \multirow{2}{*}{$\begin{array}{l}\text { PROF. } \\
(\mathrm{cm})\end{array}$} & \multirow{2}{*}{ B } & \multirow{2}{*}{ NTC } & \multicolumn{3}{|c|}{ Tipo Ericaceae $=1105$} & \multicolumn{3}{|c|}{ Tipo Peixotoa - 1067} & \multicolumn{3}{|c|}{ Tipo Dorstenia - 1032} & \multicolumn{3}{|c|}{ Tipo Stylosanthes - 1104} \\
\hline & & & & No Grăos & $P(\%)$ & C & $N^{\circ}$ Grăos & $P(\%)$ & C & No Grăos & $P(\%)$ & C & No Grắos & $\bar{P}(\%)$ & C \\
\hline \multicolumn{16}{|l|}{ S1 } \\
\hline 1 & 5.5 & 45,1223 & 922 & 0 & 0,0 & 0,0 & 0 & 0,0 & 0,0 & 1 & 0,1 & 45,1 & 0 & 0,0 & 0,0 \\
\hline 2 & 10,5 & 119,28 & 778 & 0 & 0,0 & 0,0 & 1 & 0,1 & 119,3 & 2 & 0,3 & 238,6 & 0 & 0,0 & 0,0 \\
\hline 3 & 20,5 & 69,303 & 877 & 0 & 0,0 & 0,0 & 0 & 0,0 & 0,0 & $\overline{0}$ & 0,0 & 0,0 & 0 & 0,0 & 0,0 \\
\hline 4 & 30,5 & 60,8859 & 962 & 0 & 0,0 & 0,0 & 0 & 0,0 & 0,0 & 0 & 0,0 & 0,0 & 2 & 0,2 & 121,8 \\
\hline 5 & 40,5 & 59,0672 & 903 & 0 & 0,0 & 0,0 & 0 & 0,0 & 0,0 & 0 & 0,0 & 0,0 & 0 & 0,0 & 0,0 \\
\hline 6 & 51,5 & 62,4266 & 930 & 0 & 0,0 & 0,0 & 0 & 0,0 & 0,0 & 0 & 0,0 & 0,0 & 0 & 0,0 & 0,0 \\
\hline 7 & 61,5 & 144,582 & 520 & 0 & 0,0 & 0,0 & 0 & 0,0 & 0,0 & 0 & 0,0 & 0,0 & 0 & 0,0 & 0,0 \\
\hline 8 & 70,5 & 39,9528 & 744 & 0 & 0,0 & 0,0 & 0 & 0,0 & 0,0 & 0 & 0,0 & 0,0 & 0 & 0,0 & 0,0 \\
\hline 9 & 80,5 & 95,5277 & 871 & 0 & 0,0 & 0,0 & 0 & 0,0 & 0,0 & 0 & 0,0 & 0,0 & 0 & 0,0 & 0,0 \\
\hline 10 & 90,5 & 30,138 & 341 & 0 & 0,0 & 0,0 & 0 & 0,0 & 0,0 & 0 & 0,0 & 0,0 & 0 & 0,0 & 0,0 \\
\hline 11 & 101,5 & 61,5586 & 702 & 0 & 0,0 & 0,0 & 1 & 0,1 & 61,6 & 0 & 0,0 & 0,0 & 2 & 0,3 & 123,1 \\
\hline 12 & 110,5 & 89,4261 & 537 & 0 & 0,0 & 0,0 & 3 & 0,6 & 268,3 & 0 & 0,0 & 0,0 & 0 & 0,0 & 0,0 \\
\hline 13 & 120,5 & 114,361 & 510 & 0 & 0,0 & 0,0 & 2 & 0,4 & 228,7 & 0 & 0,0 & 0,0 & 0 & 0,0 & 0,0 \\
\hline 14 & 131,5 & 133,444 & 488 & 0 & 0,0 & 0,0 & 3 & 0,6 & 400,3 & 0 & 0,0 & 0,0 & 0 & 0,0 & 0,0 \\
\hline 15 & 140,5 & 194,534 & 541 & 1 & 0,2 & 194,5 & 5 & 0,9 & 972,7 & 0 & 0,0 & 0,0 & 0 & 0,0 & 0,0 \\
\hline 16 & 150,5 & 254,669 & 858 & 0 & 0,0 & 0,0 & 0 & 0,0 & 0,0 & 0 & 0,0 & 0,0 & 0 & 0,0 & 0,0 \\
\hline 17 & 160,5 & 336,829 & 947 & 1 & 0,1 & 336,8 & 0 & 0,0 & 0,0 & 0 & 0,0 & 0,0 & 0 & 0,0 & 0,0 \\
\hline 18 & 170,5 & 405,477 & 1000 & 0 & 0,0 & 0,0 & 0 & 0,0 & 0,0 & 0 & 0,0 & 0,0 & 0 & 0,0 & 0,0 \\
\hline 19 & 180,5 & 341,247 & 1119 & 3 & 0,3 & 1023,7 & 0 & 0,0 & 0,0 & 0 & 0,0 & 0,0 & 0 & 0,0 & 0,0 \\
\hline 20 & 190,5 & 276,772 & 1239 & 0 & 0,0 & 0,0 & 0 & 0,0 & 0,0 & 0 & 0,0 & 0,0 & 0 & 0,0 & 0,0 \\
\hline 21 & 201,5 & 176,707 & 829 & 3 & 0,4 & 530,1 & 0 & 0,0 & 0,0 & 0 & 0,0 & 0,0 & 0 & 0,0 & 0,0 \\
\hline 22 & 210,5 & 210,849 & 859 & 1 & 0.1 & 210,8 & 0 & 0,0 & 0,0 & 0 & 0,0 & 0,0 & 0 & 0,0 & 0,0 \\
\hline 23 & 220,5 & 218,176 & 765 & 0 & 0,0 & 0,0 & 0 & 0,0 & 0,0 & 0 & 0,0 & 0,0 & 0 & 0,0 & 0,0 \\
\hline 24 & 230,5 & 216,228 & 715 & 3 & 0,4 & 648,7 & 0 & 0,0 & 0,0 & 0 & 0,0 & 0,0 & 0 & 0,0 & 0,0 \\
\hline 25 & 240,5 & 290,364 & 670 & 0 & 0,0 & 0,0 & 0 & 0,0 & 0,0 & 0 & 0,0 & 0,0 & 0 & 0,0 & 10,0 \\
\hline 26 & 250,5 & 144,557 & 741 & 0 & 0,0 & 0,0 & 0 & 0,0 & 0,0 & 0 & 0,0 & 0,0 & $\overline{0}$ & 0,0 & 0,0 \\
\hline 27 & 260,5 & 162,655 & 687 & 0 & 0,0 & 0,0 & 0 & 0,0 & 0,0 & 0 & 0,0 & 0,0 & 0 & 0,0 & 0,0 \\
\hline 28 & 271,5 & 332,833 & 761 & 0 & 0,0 & 0,0 & 0 & 0,0 & 0,0 & 0 & 0,0 & 0,0 & 0 & 0,0 & 0,0 \\
\hline 29 & 280,5 & 130,075 & 456 & 1 & 0,2 & 130,1 & 2 & 0.4 & 260,1 & 0 & 0,0 & 0,0 & 0 & 0,0 & 0,0 \\
\hline 30 & 290,5 & 473,217 & 0,0 & 0,0 & 0,0 & 0,0 & 0,0 & 0,0 & 0,0 & 0,0 & 0,0 & 0,0 & 0,0 & 0,0 & 0,0 \\
\hline 31 & 314,5 & 334,253 & 0,0 & 0,0 & 0,0 & 0,0 & 0,0 & 0,0 & 0,0 & 0,0 & 0,0 & 0,0 & 0,0 & 0,0 & 0,0 \\
\hline 32 & 345,5 & 612,398 & 0,0 & 0,0 & 0,0 & 0,0 & 0,0 & 0,0 & 0,0 & 0,0 & 0,0 & 0,0 & 0,0 & 0,0 & 0,0 \\
\hline
\end{tabular}


TABELA 3.3: Qualificação e quantificação dos tipos polínicos da Lagoa Bonita, DF

continuaçăo

\begin{tabular}{|c|c|c|c|c|c|c|c|c|c|c|c|c|c|c|c|}
\hline \multirow{2}{*}{ NIVEL } & \multirow{2}{*}{$\begin{array}{l}\text { PROF. } \\
\text { (cm) }\end{array}$} & \multirow{2}{*}{ B } & \multirow{2}{*}{ NTG } & \multicolumn{3}{|c|}{ Tipo Crotalaria - 1172} & \multicolumn{3}{|c|}{ Tipo Crumenaria - 1122} & \multicolumn{3}{|c|}{ Tipo Diplusodon - 1101} & \multicolumn{3}{|c|}{ Tipo Sebastiana - 1059} \\
\hline & & & & No Grăos & $\mathbf{P}(\%)$ & C & No Grắos & $P(\%)$ & C & No Grắos & $P(\%)$ & C & No Graos & $P(\%)$ & C \\
\hline S1 & & & & & & & & & & & & & & & \\
\hline 1 & 5,5 & 45,1223 & 922 & 0 & 0,0 & 0,0 & 0 & 0,0 & 0,0 & 1 & 0,1 & 45,1 & 4 & 0,4 & 180,5 \\
\hline 2 & 10,5 & 119,28 & 778 & 0 & 0,0 & 0,0 & 0 & 0,0 & 0,0 & 0 & 0,0 & 0,0 & 11 & 1,4 & 1312,1 \\
\hline 3 & 20,5 & 69,303 & 877 & 0 & 0,0 & 0,0 & $\overline{0}$ & 0,0 & 0,0 & 0 & 0,0 & 0,0 & 10 & 1,1 & 693,0 \\
\hline 4 & 30,5 & 60,8859 & 962 & 0 & 0,0 & 0,0 & 1 & 0,1 & 60,9 & 0 & 0,0 & 0,0 & 4 & 0,4 & 243,5 \\
\hline 5 & 40,5 & 59,0672 & 903 & 0 & 0,0 & 0,0 & 2 & 0,2 & 118,1 & 2 & 0,2 & 118,1 & $\overline{9}$ & 1,0 & 531,6 \\
\hline 6 & 51,5 & 62,4266 & 930 & $\overline{0}$ & 0,0 & 0,0 & 4 & 0,4 & 249,7 & 0 & 0,0 & 0,0 & 5 & 0,5 & 312,1 \\
\hline 7 & 61,5 & 144,582 & 520 & 0 & 0,0 & 0,0 & 1 & 0,2 & 144,6 & 2 & 0,4 & 289,2 & 4 & 0,8 & 578,3 \\
\hline 8 & 70,5 & 39,9528 & 744 & 0 & 0,0 & 0,0 & 7 & 0,9 & 279,7 & 0 & 0,0 & 0,0 & 3 & 0,4 & 119,9 \\
\hline 9 & 80,5 & 95,5277 & 871 & 0 & 0,0 & 0,0 & 4 & 0,5 & 382,1 & 0 & 0,0 & 0,0 & 4 & 0,5 & 382,1 \\
\hline 10 & 90,5 & 30,138 & 341 & 0 & 0,0 & 0,0 & 0 & 0,0 & 0,0 & 0 & 0,0 & 0,0 & 1 & 0,3 & 30,1 \\
\hline 11 & 101,5 & 61,5586 & 702 & 1 & 0,1 & 61,6 & 2 & 0,3 & 123,1 & 0 & 0,0 & 0,0 & 5 & 0,7 & 307,8 \\
\hline 12 & 110,5 & 89,4261 & 537 & 0 & 0,0 & 0,0 & 0 & 0,0 & 0,0 & 0 & 0,0 & 0,0 & 3 & 0,6 & 268,3 \\
\hline 13 & 120,5 & 114,361 & 510 & 0 & 0,0 & 0,0 & 0 & 0,0 & 0,0 & 0 & 0,0 & 0,0 & 3 & 0,6 & 343,1 \\
\hline 14 & 131,5 & 133,444 & 488 & 0 & 0,0 & 0,0 & 0 & 0,0 & 0,0 & 0 & 0,0 & 0,0 & 0 & 0,0 & 0,0 \\
\hline 15 & 140,5 & 194,534 & 541 & 0 & 0,0 & 0,0 & 0 & 0,0 & 0,0 & 0 & 0,0 & 0,0 & 0 & 0,0 & 0,0 \\
\hline 16 & 150,5 & 254,669 & 858 & 1 & 0,1 & 254,7 & 0 & 0,0 & 0,0 & 0 & 0,0 & 0,0 & 0 & 0,0 & 0,0 \\
\hline 17 & 160,5 & 336,829 & 947 & 1 & 0,1 & 336,8 & 0 & 0,0 & 0,0 & 0 & 0,0 & 0,0 & 5 & 0,5 & 1684,1 \\
\hline 18 & 170,5 & 405,477 & 1000 & 1 & 0,1 & 405,5 & 0 & 0,0 & 0,0 & 0 & 0,0 & 0,0 & 0 & 0,0 & 0,0 \\
\hline 19 & 180,5 & 341,247 & 1119 & 1 & 0,1 & 341,2 & 0 & 0,0 & 0,0 & 0 & 0,0 & 0,0 & 6 & 0,5 & 2047,5 \\
\hline 20 & 190,5 & 276,772 & 1239 & 0 & 0,0 & 0,0 & 0 & 0,0 & 0,0 & 0 & 0,0 & 0,0 & 0 & 0,0 & 0,0 \\
\hline 21 & 201,5 & 176,707 & 829 & 2 & 0,2 & 353,4 & 0 & 0,0 & 0,0 & 0 & 0,0 & 0,0 & 3 & 0,4 & 530,1 \\
\hline 22 & 210,5 & 210,849 & 859 & 1 & 0,1 & 210,8 & 0 & 0,0 & 0,0 & 0 & 0,0 & 0,0 & 1 & 0,1 & 210,8 \\
\hline 23 & 220,5 & 218,176 & 765 & 0 & 0,0 & 0,0 & 0 & 0,0 & 0,0 & 0 & 0,0 & 0,0 & 0 & 0,0 & 0,0 \\
\hline 24 & 230,5 & 216,228 & 715 & 2 & 0,3 & 432,5 & 0 & 0,0 & 0,0 & 0 & 0,0 & 0,0 & 4 & 0,6 & 864,9 \\
\hline 25 & 240,5 & 290,364 & 670 & 0 & 0,0 & 0,0 & 0 & 0,0 & 0,0 & 0 & 0,0 & 0,0 & 0 & 0,0 & 0,0 \\
\hline 26 & 250,5 & 144,557 & 741 & 0 & 0,0 & 0,0 & 0 & 0,0 & 0,0 & 0 & 0,0 & 0,0 & 0 & 0,0 & 0,0 \\
\hline 27 & 260,5 & 162,655 & 687 & 0 & 0,0 & 0,0 & 0 & 0,0 & 0,0 & 0 & 0,0 & 0,0 & 0 & 0,0 & 0,0 \\
\hline 28 & 271,5 & 332,833 & 761 & 2 & 0,3 & 665,7 & 0 & 0,0 & 0,0 & 0 & 0,0 & 0,0 & 1 & 0,1 & 332,8 \\
\hline 29 & 280,5 & 130,075 & 456 & 0 & 0,0 & 0,0 & 0 & 0,0 & 0,0 & 0 & 0,0 & 0,0 & 0 & 0,0 & 0,0 \\
\hline 30 & 290,5 & 473,217 & 0,0 & 0,0 & $0, \overline{0}$ & 0,0 & 0,0 & 0,0 & 0,0 & 0,0 & 0,0 & 0,0 & 0,0 & 0,0 & 0,0 \\
\hline 31 & 314,5 & 334,253 & 0,0 & 0,0 & 0,0 & 0,0 & 0,0 & 0,0 & 0,0 & 0,0 & 0,0 & 0,0 & 0,0 & 0,0 & 0,0 \\
\hline 32 & 345,5 & 612,398 & 0,0 & 0,0 & 0,0 & 0,0 & 0,0 & 0,0 & 0,0 & 0,0 & 0,0 & 0,0 & 0,0 & 0,0 & 0,0 \\
\hline
\end{tabular}


TABELA 3.3: Qualificação e quantificação dos tipos polínicos da Lagoa Bonita, DF

\begin{tabular}{|c|c|c|c|c|c|c|c|c|c|c|c|c|c|c|c|}
\hline \multirow{2}{*}{ NIVEL } & \multirow{2}{*}{$\begin{array}{l}\text { PROF. } \\
\text { (cm) }\end{array}$} & \multirow{2}{*}{ B } & \multirow{2}{*}{ NTG } & \multicolumn{3}{|c|}{ Tipo Mauritia - 1019} & \multicolumn{3}{|c|}{ Tipo Cyperaceae - 1015} & \multicolumn{3}{|c|}{ Tipo Pontederiaceae - 1174} & \multicolumn{3}{|c|}{ Tipo Alismataceae - 1054} \\
\hline & & & & No Gräos & $\mathbf{P}(\%)$ & C & $N^{\circ}$ Gräos & $P(\%)$ & $\mathbf{C}$ & $N^{0}$ Grăos & $P(\%)$ & C & $\mathrm{N}^{\circ}$ Gräos & $P(\%)$ & C \\
\hline \multicolumn{16}{|l|}{ S1 } \\
\hline 1 & 5,5 & 45,1223 & 922 & 8 & 0,9 & 361,0 & 61 & 6,6 & 2752,5 & 1 & 0,1 & 45,1 & 17 & 1,8 & 767,1 \\
\hline 2 & 10,5 & 119,28 & 778 & 5 & 0,6 & 596,4 & 17 & 2,2 & 2027,8 & 0 & 0,0 & 0,0 & 10 & 1,3 & 1192,8 \\
\hline 3 & 20,5 & 69,303 & 877 & 0 & 0,0 & 0,0 & 68 & 7,8 & $4 \overline{712,6}$ & 2 & 0,2 & 138,6 & 7 & 0,8 & 485,1 \\
\hline 4 & 30,5 & 60,8859 & 962 & 5 & 0,5 & 304,4 & 55 & 5,7 & 3348,7 & 0 & 0,0 & 0,0 & 8 & 0,8 & 487,1 \\
\hline 5 & 40,5 & 59,0672 & 903 & 2 & 0,2 & 118,1 & 35 & 3,9 & 2067,4 & 0 & 0,0 & 0,0 & 8 & 0,9 & 472,5 \\
\hline 6 & 51,5 & 62,4266 & 930 & 3 & $\overline{0,3}$ & 187,3 & 39 & 4,2 & 2434,6 & $\overline{0}$ & 0,0 & 0,0 & 6 & 0,6 & 374,6 \\
\hline 7 & 61,5 & 144,582 & 520 & $\begin{array}{l}0 \\
0\end{array}$ & 0,0 & 0,0 & 52 & 10,0 & 7518,3 & 1 & 0,2 & 144,6 & 2 & 0,4 & 289,2 \\
\hline 8 & 70,5 & 39,9528 & 744 & 3 & 0,4 & 119,9 & 55 & 7,4 & 2197,4 & 0 & 0,0 & 0,0 & 5 & 0,7 & 199,8 \\
\hline 9 & 80,5 & 95,5277 & 871 & 0 & 0,0 & 0,0 & 40 & 4,6 & 3821,1 & 0 & 0,0 & 0,0 & 1 & 0,1 & 95,5 \\
\hline 10 & 90,5 & 30,138 & 341 & 0 & 0,0 & 0,0 & 39 & 11,4 & 1175,4 & 0 & 0,0 & 0,0 & 0 & 0,0 & 0,0 \\
\hline 11 & 101,5 & 61,5586 & 702 & 0 & 0,0 & 0,0 & 57 & 8,1 & 3508,8 & 5 & $0, \overline{7}$ & 307,8 & 0 & 0,0 & 0,0 \\
\hline 12 & 110,5 & 89,4261 & 537 & 0 & 0,0 & 0,0 & 47 & 8,8 & 4203,0 & 12 & 2,2 & 1073,1 & 4 & 0,7 & 357,7 \\
\hline 13 & 120,5 & 114,361 & 510 & 0 & 0,0 & 0,0 & 57 & 11,2 & 6518,6 & 5 & 1,0 & 571,8 & 1 & 0,2 & 114,4 \\
\hline 14 & 131,5 & 133,444 & 488 & 0 & 0,0 & 0,0 & 63 & 12,9 & 8407,0 & 24 & 4,9 & 3202,6 & 0 & 0,0 & 0,0 \\
\hline 15 & 140,5 & 194,534 & 541 & 0 & 0,0 & 0,0 & 82 & 15,2 & 15951,8 & 14 & 2,6 & 2723,5 & 1 & 0,2 & 194,5 \\
\hline 16 & 150,5 & 254,669 & 858 & 0 & 0,0 & 0,0 & 82 & 9,6 & 20882,8 & 86 & 10,0 & 21901,5 & 20 & 2,3 & 5093,4 \\
\hline 17 & 160,5 & 336,829 & 947 & 0 & 0,0 & 0,0 & 100 & 10,6 & 33682,9 & 110 & 11,6 & 37051,1 & 31 & 3,3 & 10441,7 \\
\hline 18 & 170,5 & 405,477 & 1000 & 0 & 0,0 & 0,0 & 113 & 11,3 & 45818,9 & 174 & 17,4 & 70553,1 & 24 & 2,4 & 9731,5 \\
\hline 19 & 180,5 & 341,247 & 1119 & 0 & 0,0 & 0,0 & 148 & 13,2 & 50504,6 & 180 & 16,1 & 61424,5 & 30 & 2,7 & 10237,4 \\
\hline 20 & 190,5 & 276,772 & 1239 & 0 & 0,0 & 0,0 & 151 & 12,2 & 41792,6 & 209 & 16,9 & 57845,4 & 31 & 2,5 & 8579,9 \\
\hline 21 & 201,5 & 176,707 & 829 & 0 & 0,0 & 0,0 & 78 & 9,4 & 13783,1 & 128 & 15,4 & 22618,5 & 27 & 3,3 & 4771,1 \\
\hline 22 & 210,5 & 210,849 & 859 & 0 & 0,0 & 0,0 & 86 & 10,0 & 18133,0 & 102 & 11,9 & 21506,6 & 30 & 3,5 & 6325,5 \\
\hline 23 & 220,5 & 218,176 & 765 & 0 & 0,0 & 0,0 & 65 & 8,5 & 14181,4 & 136 & 17,8 & 29672,0 & 47 & 6,1 & 10254,3 \\
\hline 24 & 230,5 & 216,228 & 715 & 0 & 0,0 & 0,0 & 99 & 13,8 & 21406,6 & 120 & 16,8 & 25947,4 & $2 \overline{3}$ & 3,2 & 4973,2 \\
\hline 25 & 240,5 & 290,364 & 670 & 0 & 0,0 & 0,0 & 96 & 14,3 & 27874,9 & 141 & 21,0 & 40941,3 & 34 & 5,1 & 9872,4 \\
\hline 26 & 250,5 & 144,557 & 741 & 0 & 0,0 & 0,0 & 103 & 13,9 & 14889,4 & 122 & 16,5 & 17636,0 & 32 & 4,3 & 4625,8 \\
\hline 27 & 260,5 & 162,655 & 687 & 0 & 0,0 & 0,0 & 139 & 20,2 & 22609,1 & 84 & 12,2 & 13663,0 & 36 & 5,2 & 5855,6 \\
\hline 28 & 271,5 & 332,833 & 761 & 0 & 0,0 & 0,0 & 156 & 20,5 & 51921,9 & 91 & 12,0 & 30287,8 & 40 & 5,3 & 13313,3 \\
\hline 29 & 280,5 & 130,075 & 456 & 0 & 0,0 & 0,0 & 114 & 25,0 & 14828,5 & 52 & 11,4 & 6763,9 & 33 & 7,2 & 4292,5 \\
\hline 30 & 290,5 & 473,217 & 0,0 & 0,0 & 0,0 & 0,0 & 0,0 & 0,0 & 0,0 & 0,0 & 0,0 & 0,0 & 0,0 & 0,0 & 0,0 \\
\hline 31 & 314,5 & 334,253 & 0,0 & 0,0 & 0,0 & 0,0 & 0,0 & 0,0 & 0,0 & 0,0 & 0,0 & 0,0 & 0,0 & 0,0 & 0,0 \\
\hline 32 & 345,5 & 612,398 & 0,0 & 0,0 & 0,0 & 0,0 & 0,0 & 0,0 & 0,0 & 0,0 & 0,0 & 0,0 & 0,0 & 0,0 & 0,0 \\
\hline
\end{tabular}


TABELA 3.3: Qualificação e quantificação dos tipos polínicos da Lagoa Bonita, DF

continuação

\begin{tabular}{|c|c|c|c|c|c|c|c|c|c|c|c|c|c|c|c|}
\hline \multirow{2}{*}{ NIVEL } & \multirow{2}{*}{$\begin{array}{l}\text { PROF. } \\
\text { (cm) }\end{array}$} & \multirow{2}{*}{ B } & \multirow{2}{*}{ NTE } & \multicolumn{3}{|c|}{ Tipo Umbeliferae - 1069} & \multicolumn{3}{|c|}{ Tipo Myriophyllum - 1183} & \multicolumn{3}{|c|}{ Tipo Utricularia - 1194} & \multicolumn{3}{|c|}{ Tipo Drosera - 1033} \\
\hline & & & & No Grăos & $\mathbf{P ( \% )}$ & C & N०Crăos & $P(\%)$ & C & No Gráos & $P(\%)$ & C & No Grăos & $P(\%)$ & C \\
\hline \multicolumn{16}{|c|}{10} \\
\hline 1 & 5,5 & 45,1223 & 922 & 18 & 2,0 & 812,2 & 2 & 0,2 & 90,2 & 0 & 0,0 & 0,0 & 1 & 0,1 & 45,1 \\
\hline 2 & 10,5 & 119,28 & 778 & 12 & 1,5 & 1431,4 & 3 & 0,4 & 357,8 & 0 & 0,0 & 0,0 & 0 & 0,0 & 0,0 \\
\hline 3 & 20,5 & 69,303 & 877 & 18 & 2,1 & 1247,5 & 1 & 0,1 & 69,3 & 0 & 0,0 & 0,0 & 0 & 0,0 & 0,0 \\
\hline 4 & 30,5 & 60,8859 & 962 & 29 & 3,0 & 1765,7 & 2 & 0,2 & 121,8 & 0 & 0,0 & 0,0 & 0 & 0,0 & 0,0 \\
\hline 5 & 40,5 & 59,0672 & 903 & 3 & 0,3 & 177,2 & 1 & 0,1 & 59,1 & 0 & 0,0 & 0,0 & o & 0,0 & 0,0 \\
\hline$\overline{6}$ & 51,5 & 62,4266 & 930 & 8 & 0,9 & 499,4 & 3 & 0,3 & 187,3 & $\overline{0}$ & 0,0 & 0,0 & 0 & 0,0 & 0,0 \\
\hline 7 & 61,5 & 144,582 & 520 & 3 & 0,6 & 433,7 & 0 & 0,0 & 0,0 & 0 & 0,0 & 0,0 & 0 & 0,0 & 0,0 \\
\hline 8 & 70,5 & 39,9528 & 744 & 3 & 0,4 & 119,9 & 3 & 0,4 & 119,9 & 0 & 0,0 & 0,0 & 0 & 0,0 & 0,0 \\
\hline 9 & 80,5 & 95,5277 & 871 & 12 & 1,4 & 1146,3 & 4 & 0,5 & 382,1 & $\overline{0}$ & 0,0 & 0,0 & 0 & 0,0 & 0,0 \\
\hline 10 & 90,5 & 30,138 & 341 & 9 & 2,6 & 271,2 & 4 & 1,2 & 120,6 & 0 & 0,0 & 0,0 & 0 & 0,0 & 0,0 \\
\hline 11 & 101,5 & 61,5586 & 702 & 2 & 0,3 & $\sqrt{23,1}$ & 0 & 0,0 & 0,0 & 0 & 0,0 & 0,0 & 0 & 0,0 & 0,0 \\
\hline 12 & 110,5 & 89,4261 & 537 & 3 & 0,6 & 268,3 & 2 & 0,4 & 178,9 & 0 & 0,0 & 0,0 & $\overline{0}$ & 0,0 & 0,0 \\
\hline 13 & 120,5 & 114,361 & 510 & 10 & 2,0 & 1143,6 & 0 & 0,0 & 0,0 & 0 & 0,0 & 0,0 & 0 & 0,0 & 0,0 \\
\hline 14 & 131,5 & 133,444 & 488 & 6 & 1,2 & 800,7 & 0 & 0,0 & 0,0 & 0 & 0,0 & 0,0 & 0 & 0,0 & 0,0 \\
\hline 15 & 140,5 & 194,534 & 541 & 5 & 0,9 & 972,7 & 0 & 0,0 & 0,0 & 0 & 0,0 & 0,0 & 1 & 0,2 & 194,5 \\
\hline 16 & 150,5 & 254,669 & 858 & 0 & 0,0 & 0,0 & 1 & 0,1 & 254,7 & 0 & 0,0 & 0,0 & 1 & 0,1 & 254,7 \\
\hline 17 & 160,5 & 336,829 & 947 & 4 & 0,4 & 1347,3 & 3 & 0,3 & 1010,5 & 0 & 0,0 & 0,0 & 2 & 0,2 & 673,7 \\
\hline 18 & 170,5 & 405,477 & 1000 & 4 & 0,4 & 1621,9 & 1 & 0,1 & 405,5 & 1 & 0,1 & 405,5 & 0 & 0,0 & 0,0 \\
\hline 19 & 180,5 & 341,247 & 1119 & 0 & 0,0 & 0,0 & 2 & 0,2 & 682,5 & 1 & 0,1 & 341,2 & 4 & 0,4 & 1365,0 \\
\hline 20 & 190,5 & 276,772 & 1239 & 6 & 0.5 & 1660,6 & 0 & 0,0 & 0,0 & 4 & 0,3 & 1107,1 & 3 & 0,2 & 830,3 \\
\hline 21 & 201,5 & 176,707 & 829 & 4 & 0.5 & 706,8 & 3 & 0,4 & 530,1 & 2 & 0,2 & 353,4 & 2 & 0,2 & 353,4 \\
\hline 22 & 210,5 & 210,849 & 859 & 1 & 0,1 & 210,8 & 0 & 0,0 & 0,0 & 2 & 0,2 & 421,7 & 2 & 0,2 & 421,7 \\
\hline 23 & 220,5 & 218,176 & 765 & 2 & 0,3 & 436,4 & 26 & 3,4 & 5672,6 & 5 & 0,7 & 1090,9 & 0 & 0,0 & 0,0 \\
\hline 24 & 230,5 & 216,228 & 715 & 3 & 0,4 & 648,7 & 9 & 1,3 & 1946,1 & 1 & 0,1 & 216,2 & 1 & 0,1 & 216,2 \\
\hline 25 & 240,5 & 290,364 & 670 & 1 & 0,1 & 290,4 & 9 & 1,3 & 2613,3 & $i$ & 0,1 & 290,4 & 2 & 0,3 & 580,7 \\
\hline 26 & 250,5 & 144,557 & 741 & 5 & 0,7 & 722,8 & 16 & 2,2 & 2312,9 & 2 & 0,3 & 289,1 & 0 & 0,0 & 0,0 \\
\hline 27 & 260,5 & 162,655 & 687 & 7 & 1,0 & 1138,6 & 8 & 1,2 & 1301,2 & 0 & 0,0 & 0,0 & 2 & 0,3 & 325,3 \\
\hline 28 & 271,5 & 332,833 & 761 & 2 & 0,3 & 665,7 & 18 & 2,4 & 5991,0 & 0 & 0,0 & 0,0 & $\overline{0}$ & 0,0 & 0,0 \\
\hline 29 & 280,5 & 130,075 & 456 & 0 & 0,0 & 0,0 & 9 & 2,0 & 1170,7 & 1 & 0,2 & 130,1 & 0 & 0,0 & 0,0 \\
\hline 30 & 290,5 & 473,217 & 0,0 & 0,0 & 0,0 & 0,0 & 0,0 & 0,0 & 0,0 & 0,0 & 0,0 & 0,0 & 0,0 & 0,0 & 0,0 \\
\hline 31 & 314,5 & 334,253 & 0,0 & 0,0 & 0,0 & 0,0 & 0,0 & 0,0 & 0,0 & 0,0 & 0,0 & 0,0 & 0,0 & 0,0 & 0,0 \\
\hline 32 & 345,5 & 612,398 & 0,0 & 0,0 & 0,0 & 0,0 & 0,0 & 0,0 & 0,0 & 0,0 & 0,0 & 0,0 & 0,0 & 0,0 & 0,0 \\
\hline
\end{tabular}


TABELA 3.3: Qualificação e quantificação dos tipos polínicos da Lagoa Bonita, DF

continuaçăo

\begin{tabular}{|c|c|c|c|c|c|c|c|c|c|c|c|c|c|c|c|}
\hline \multirow{2}{*}{ NIVEL } & \multirow{2}{*}{$\begin{array}{l}\text { PROF. } \\
\text { (cm) }\end{array}$} & \multirow{2}{*}{ B } & \multirow{2}{*}{ NTO } & \multicolumn{3}{|c|}{ Tipo Typha - 1118} & \multicolumn{3}{|c|}{ Tipo-1077 } & \multicolumn{3}{|c|}{ Tipo-1103 } & \multicolumn{3}{|c|}{ Tipo-1040 } \\
\hline & & & & No Grás & $P(\%)$ & C & 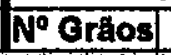 & $\bar{P}(\%)$ & $\mathbf{C}$ & No Crăos & $P(\%)$ & $\mathbf{C}$ & No Grãos & $\bar{P}(\%)$ & C \\
\hline \multicolumn{16}{|l|}{$\overline{\mathrm{s1}}$} \\
\hline 1 & 5,5 & 45,1223 & 922 & 0 & 0,0 & 0,0 & 7 & 0,8 & 315,9 & 6 & 0,7 & 270,7 & 0 & 0,0 & 0,0 \\
\hline 2 & 10,5 & 119,28 & 778 & 0 & 0,0 & 0,0 & 6 & 0,8 & 715,7 & $\overline{0}$ & 0,0 & 0,0 & $\overline{3}$ & 0,4 & 357,8 \\
\hline 3 & 20,5 & 69,303 & 877 & 0 & 0,0 & 0,0 & 3 & 0,3 & 207,9 & 0 & 0,0 & 0,0 & 4 & 0,5 & 277,2 \\
\hline 4 & 30,5 & 60,8859 & 962 & 2 & 0,2 & 121,8 & 11 & 1,1 & 669,7 & 10 & 1,0 & 608,9 & 9 & 0,9 & 548,0 \\
\hline$\overline{5}$ & 40,5 & 59,0672 & $\overline{90} \overline{3}$ & 1 & 0,1 & 59,1 & 12 & 1,3 & 708,8 & 6 & 0,7 & 354,4 & 2 & 0,2 & 118,1 \\
\hline 6 & 51,5 & 62,4266 & 930 & 0 & 0,0 & 0,0 & 0 & 0,0 & 0,0 & 11 & 1,2 & 686,7 & 0 & 0,0 & 0,0 \\
\hline 7 & 61,5 & 144,582 & 520 & 0 & 0,0 & 0,0 & 12 & 2,3 & 1735,0 & 3 & 0,6 & 433,7 & 1 & 0,2 & 144,6 \\
\hline 8 & $\overline{70,5}$ & 39,9528 & 744 & 0 & 0,0 & 0,0 & 8 & 1,1 & 319,6 & 2 & 0,3 & 79,9 & 1 & 0,1 & 40,0 \\
\hline 9 & 80,5 & 95,5277 & 871 & 0 & 0,0 & 0,0 & 3 & 0,3 & 286,6 & 2 & 0,2 & 191,1 & 0 & 0,0 & 0,0 \\
\hline 10 & 90,5 & 30,138 & 341 & 0 & 0,0 & 0,0 & 5 & 1,5 & 150,7 & 0 & 0,0 & 0,0 & 0 & 0,0 & 0,0 \\
\hline 11 & 101,5 & 61,5586 & 702 & 0 & 0,0 & 0,0 & 7 & 1,0 & 430,9 & 4 & 0,6 & 246,2 & 2 & 0,3 & 123,1 \\
\hline 12 & 110,5 & 89,4261 & 537 & 0 & 0,0 & 0,0 & 7 & 1,3 & 626,0 & 0 & 0,0 & 0,0 & 1 & 0,2 & 89,4 \\
\hline 13 & 120,5 & 114,361 & 510 & 0 & 0,0 & 0,0 & 15 & 2,9 & 1715,4 & 3 & 0,6 & 343,1 & 1 & 0,2 & 114,4 \\
\hline 14 & 131,5 & 133,444 & 488 & 0 & 0,0 & 0,0 & 7 & 1,4 & 934,1 & 0 & 0,0 & 0,0 & 0 & 0,0 & 0,0 \\
\hline 15 & 140,5 & 194,534 & 541 & 0 & 0,0 & 0,0 & 4 & 0,7 & 778,1 & 0 & 0,0 & 0,0 & 1 & 0,2 & 194,5 \\
\hline 16 & 150,5 & 254,669 & 858 & 1 & 0,1 & 254,7 & 3 & 0,3 & 764,0 & 2 & 0,2 & 509,3 & 0 & 0,0 & 0,0 \\
\hline 17 & 160,5 & 336,829 & 947 & 3 & 0,3 & 1010,5 & 0 & 0,0 & 0,0 & 0 & 0,0 & 0,0 & 0 & 0,0 & 0,0 \\
\hline 18 & 170,5 & 405,477 & 1000 & 0 & 0,0 & 0,0 & 5 & 0,5 & 2027,4 & 3 & 0,3 & 1216,4 & 0 & 0,0 & 0,0 \\
\hline 19 & 180,5 & 341,247 & 1119 & 0 & 0,0 & 0,0 & 3 & 0,3 & 1023,7 & 5 & 0,4 & 1706,2 & 0 & 0,0 & 0,0 \\
\hline 20 & 190,5 & 276,772 & 1239 & 0 & 0,0 & 0,0 & 1 & 0,1 & 276,8 & 0 & 0,0 & 0,0 & 0 & 0,0 & 0,0 \\
\hline 21 & 201,5 & 176,707 & 829 & 0 & 0,0 & 0,0 & 7 & 0.8 & 1236,9 & 1 & 0,1 & 176,7 & 1 & 0,1 & 176,7 \\
\hline 22 & 210,5 & 210,849 & 859 & 0 & 0,0 & 0,0 & 4 & 0,5 & 843,4 & 2 & 0,2 & 421,7 & 1 & 0,1 & 210,8 \\
\hline 23 & 220,5 & 218,176 & 765 & 0 & 0,0 & 0,0 & 7 & 0,9 & 1527,2 & 3 & 0,4 & 654,5 & 0 & 0,0 & 0,0 \\
\hline 24 & 230,5 & 216,228 & 715 & 0 & 0,0 & 0,0 & 4 & 0,6 & 864,9 & 2 & 0,3 & 432,5 & 0 & 0,0 & 0,0 \\
\hline 25 & 240,5 & 290,364 & 670 & 0 & 0,0 & 0,0 & 9 & 1,3 & 2613,3 & 3 & 0,4 & 871,1 & 0 & 0,0 & 0,0 \\
\hline 26 & 250,5 & 144,557 & 741 & 1 & 0,1 & 144,6 & 2 & 0,3 & 289,1 & 3 & 0,4 & 433,7 & 1 & 0,1 & 144,6 \\
\hline 27 & 260,5 & 162,655 & 687 & 0 & 0,0 & 0,0 & 9 & 1,3 & 1463,9 & 3 & 0,4 & 488,0 & 0 & 0,0 & 0,0 \\
\hline 28 & 271,5 & 332,833 & 761 & 0 & 0,0 & 0,0 & 11 & 1,4 & 3661,2 & $\overline{2}$ & 0,3 & 665,7 & 0 & 0,0 & 0,0 \\
\hline 29 & 280,5 & 130,075 & 456 & 0 & 0,0 & 0,0 & 4 & 0,9 & 520,3 & 0 & 0,0 & 0,0 & $\overline{0}$ & 0,0 & 0,0 \\
\hline 30 & 290,5 & 473,217 & 0,0 & 0,0 & 0,0 & 0,0 & 0,0 & 0,0 & 0,0 & 0,0 & 0,0 & 0,0 & 0,0 & 0,0 & 0,0 \\
\hline 31 & 314,5 & 334,253 & 0,0 & 0,0 & 0,0 & 0,0 & 0,0 & 0,0 & 0,0 & 0,0 & 0,0 & 0,0 & 0,0 & 0,0 & 0,0 \\
\hline 32 & 345,5 & 612,398 & 0,0 & 0,0 & 0,0 & 0,0 & 0,0 & 0,0 & 0,0 & 0,0 & 0,0 & 0,0 & $\overline{0,0}$ & 0,0 & 0,0 \\
\hline
\end{tabular}


TABELA 3.3: Qualificação e quantificação dos tipos polinicos da Lagoa Bonita, DF

continuaçăo

\begin{tabular}{|c|c|c|c|c|c|c|c|c|c|c|c|c|c|c|c|}
\hline \multirow{2}{*}{ NIVEL } & \multirow{2}{*}{$\begin{array}{l}\text { PROF. } \\
\text { (cm) }\end{array}$} & \multirow{2}{*}{ B } & \multirow{2}{*}{ NTG } & \multicolumn{3}{|c|}{ Tipo Trigonia - 1008} & \multicolumn{3}{|c|}{ Tipo Serjania - 1139} & \multicolumn{3}{|c|}{ Tipo Aristolochia - 1022} & \multicolumn{3}{|c|}{ Tipo Cayaponia - 1129} \\
\hline & & & & N ${ }^{0}$ Grăos & $P(\%)$ & C & No Grăos & $P(\%)$ & C & No Grăos & $\mathbf{P}(\%)$ & C & No Grắos & $P(\%)$ & C \\
\hline \multicolumn{16}{|l|}{ S1 } \\
\hline 1 & 5,5 & 45,1223 & 922 & 0 & 0,0 & 0,0 & 0 & 0,0 & 0,0 & 3 & 0,3 & 135,4 & 0 & 0,0 & 0,0 \\
\hline 2 & 10,5 & 119,28 & 778 & 3 & 0,4 & 357,8 & 0 & 0,0 & 0,0 & 2 & 0,3 & 238,6 & 0 & 0,0 & 0,0 \\
\hline 3 & 20,5 & 69,303 & 877 & 2 & 0,2 & 138,6 & 0 & 0,0 & 0,0 & 0 & 0,0 & 0,0 & 0 & 0,0 & 0,0 \\
\hline 4 & 30,5 & 60,8859 & 962 & 1 & 0,1 & 60,9 & 0 & 0,0 & 0,0 & 1 & 0,1 & 60,9 & 0 & 0,0 & 0,0 \\
\hline 5 & 40,5 & 59,0672 & 903 & 0 & 0,0 & 0,0 & 0 & 0,0 & 0,0 & 2 & 0,2 & 118,1 & 2 & 0,2 & 118,1 \\
\hline 6 & 51,5 & 62,4266 & 930 & 0 & 0,0 & 0,0 & 1 & 0,1 & 62,4 & 0 & 0,0 & 0,0 & 1 & 0,1 & 62,4 \\
\hline 7 & 61,5 & 144,582 & 520 & 0 & 0,0 & 0,0 & 0 & 0,0 & 0,0 & 1 & 0,2 & 144,6 & 0 & 0,0 & 0,0 \\
\hline 8 & 70,5 & 39,9528 & 744 & 2 & 0,3 & 79,9 & $\overline{0}$ & 0,0 & 0,0 & 0 & 0,0 & 0,0 & 0 & 0,0 & 0,0 \\
\hline 9 & 80,5 & 95,5277 & 871 & 0 & 0,0 & 0,0 & 1 & 0,1 & 95,5 & 0 & 0,0 & 0,0 & 0 & 0,0 & 0,0 \\
\hline 10 & 90,5 & 30,138 & 341 & 0 & 0,0 & 0,0 & 2 & 0,6 & 60,3 & 0 & 0,0 & 0,0 & 0 & 0,0 & 0,0 \\
\hline 11 & 101,5 & 61,5586 & 702 & 0 & 0,0 & 0,0 & 0 & 0,0 & 0,0 & 0 & 0,0 & 0,0 & 0 & 0,0 & 0,0 \\
\hline 12 & 110,5 & 89,4261 & 537 & 0 & 0,0 & 0,0 & 1 & 0,2 & 89,4 & 0 & 0,0 & 0,0 & 0 & 0,0 & 0,0 \\
\hline 13 & 120,5 & 114,361 & 510 & 0 & 0,0 & 0,0 & 0 & 0,0 & 0,0 & 6 & 1,2 & 686,2 & 0 & 0,0 & 0,0 \\
\hline 14 & 131,5 & 133,444 & 488 & 0 & 0,0 & 0,0 & 1 & 0,2 & 133,4 & 0 & 0,0 & 0,0 & 0 & 0,0 & 0,0 \\
\hline 15 & 140,5 & 194,534 & 541 & 0 & 0,0 & 0,0 & 2 & 0,4 & 389,1 & 2 & 0,4 & 389,1 & 0 & 0,0 & 0,0 \\
\hline 16 & 150,5 & 254,669 & 858 & 0 & 0,0 & 0,0 & 0 & 0,0 & 0,0 & 0 & 0,0 & 0,0 & 0 & 0,0 & 0,0 \\
\hline 17 & 160,5 & 336,829 & 947 & 0 & 0,0 & 0,0 & 0 & 0,0 & 0,0 & 2 & 0,2 & 673,7 & 0 & 0,0 & 0,0 \\
\hline 18 & 170,5 & 405,477 & 1000 & 0 & 0,0 & 0,0 & 0 & 0,0 & 0,0 & 0 & 0,0 & 0,0 & 0 & 0,0 & 0,0 \\
\hline 19 & 180,5 & 341,247 & 1119 & 1 & 0,1 & 341,2 & 0 & 0,0 & 0,0 & 0 & 0,0 & 0,0 & 0 & 0,0 & 0,0 \\
\hline 20 & 190,5 & 276,772 & 1239 & 0 & 0,0 & 0,0 & 0 & 0,0 & 0,0 & 1 & 0,1 & 276,8 & 0 & 0,0 & 0,0 \\
\hline 21 & 201,5 & 176,707 & 829 & 0 & 0,0 & 0,0 & 0 & 0,0 & 0,0 & $i$ & 0,1 & 176,7 & 0 & 0,0 & 0,0 \\
\hline 22 & 210,5 & 210,849 & 859 & 0 & 0,0 & 0,0 & 0 & 0,0 & 0,0 & 0 & 0,0 & 0,0 & 0 & 0,0 & 0,0 \\
\hline 23 & 220,5 & 218,176 & 765 & 0 & 0,0 & 0,0 & 1 & 0,1 & 218,2 & 0 & 0,0 & 0,0 & 0 & 0,0 & 0,0 \\
\hline 24 & 230,5 & 216,228 & 715 & 0 & 0,0 & 0,0 & 1 & 0,1 & 216,2 & 0 & 0,0 & 0,0 & 0 & 0,0 & 0,0 \\
\hline 25 & 240,5 & 290,364 & 670 & 0 & 0,0 & 0,0 & 0 & 0,0 & 0,0 & 0 & 0,0 & 0,0 & 0 & 0,0 & 0,0 \\
\hline 26 & 250,5 & 144,557 & 741 & 0 & 0,0 & 0,0 & 0 & 0,0 & 0,0 & 1 & 0,1 & 144,6 & 0 & 0,0 & 0,0 \\
\hline 27 & 260,5 & 162,655 & 687 & 0 & 0,0 & 0,0 & 0 & 0,0 & 0,0 & 0 & 0,0 & 0,0 & 0 & 0,0 & 0,0 \\
\hline 28 & 271,5 & 332,833 & 761 & 0 & 0,0 & 0,0 & 1 & 0,1 & 332,8 & 0 & 0,0 & 0,0 & 0 & 0,0 & 0,0 \\
\hline 29 & 280,5 & 130,075 & 456 & 0 & 0,0 & 0,0 & 0 & 0,0 & 0,0 & 0 & 0,0 & 0,0 & 0 & 0,0 & 0,0 \\
\hline 30 & 290,5 & 473,217 & 0,0 & 0,0 & 0,0 & 0,0 & 0,0 & 0,0 & 0,0 & 0,0 & 0,0 & 0,0 & 0,0 & 0,0 & 0,0 \\
\hline 31 & 314,5 & 334,253 & 0,0 & 0,0 & 0,0 & 0,0 & 0,0 & 0,0 & 0,0 & 0,0 & 0,0 & 0,0 & 0,0 & 0,0 & 0,0 \\
\hline 32 & 345,5 & 612,398 & 0,0 & 0,0 & 0,0 & 0,0 & 0,0 & 0,0 & 0,0 & 0,0 & 0,0 & 0,0 & 0,0 & 0,0 & 0,0 \\
\hline
\end{tabular}


TABELA 3.3: Qualificação e quantificação dos tipos polínicos da Lagoa Bonita, DF

\begin{tabular}{|c|c|c|c|c|c|c|c|c|c|c|c|c|c|c|c|}
\hline \multirow{2}{*}{ NIVEL } & \multirow{2}{*}{$\begin{array}{l}\text { PROF. } \\
\text { (cm) }\end{array}$} & \multirow{2}{*}{ B } & \multirow{2}{*}{ NTO } & \multicolumn{3}{|c|}{ Iipo Caesalpinioldeae A - 1068} & \multicolumn{3}{|c|}{ Tipo 1087} & \multicolumn{3}{|c|}{ Tipos Não ldentíficados Raro: } & \multirow[b]{2}{*}{ No Grăos } & \multirow[b]{2}{*}{$P(\%)$} & \multirow[b]{2}{*}{ C } \\
\hline & & & & No Graos & $P(\%)$ & $\mathbf{C}$ & N Grăos & $\mathbf{P}(\%)$ & C & N. Grä́s & $P(\%)$ & $\mathbf{C}$ & & & \\
\hline S1 & & & & & & & & & & & & & & & \\
\hline 1 & 5,5 & 45,1223 & 922 & 2 & 0,2 & 90,2 & 6 & 0,7 & 270,7 & 12 & 1,3 & 541,5 & & 0,0 & 0,0 \\
\hline 2 & 10,5 & 119,28 & 778 & 6 & 0,8 & 715,7 & 0 & 0,0 & 0,0 & 24 & 3,1 & 2862,7 & & 0,0 & 0,0 \\
\hline 3 & 20,5 & 69,303 & 877 & 5 & 0,6 & $\overline{346,5}$ & $\overline{12}$ & 1,4 & 831,6 & 14 & 1,6 & 970,2 & & 0,0 & 0,0 \\
\hline 4 & 30,5 & 60,8859 & 962 & 3 & 0,3 & 182,7 & 7 & 0,7 & 426,2 & 17 & 1,8 & 1035,1 & & 0,0 & 0,0 \\
\hline 5 & 40,5 & 59,0672 & 903 & 3 & 0,3 & 177,2 & 11 & 1,2 & 649,7 & 11 & 1,2 & 649,7 & & 0,0 & 0,0 \\
\hline 6 & 51,5 & 62,4266 & 930 & 3 & 0,3 & 187,3 & 7 & 0,8 & 437,0 & 16 & 1,7 & 998,8 & & 0,0 & 0,0 \\
\hline 7 & 61,5 & 144,582 & 520 & 0 & 0,0 & 0,0 & 0 & 0,0 & 0,0 & 6 & 1,2 & 867,5 & & 0,0 & 0,0 \\
\hline 8 & 70,5 & 39,9528 & $\overline{744}$ & 0 & 0,0 & 0,0 & 9 & 1,2 & 359,6 & 7 & 0,9 & 279,7 & & 0,0 & 0,0 \\
\hline 9 & 80,5 & 95,5277 & 871 & 0 & 0,0 & 0,0 & 5 & 0,6 & 477,6 & 10 & 1,1 & 955,3 & & 0,0 & 0,0 \\
\hline 10 & 90,5 & 30,138 & 341 & 0 & 0,0 & 0,0 & 0 & 0,0 & 0,0 & 0 & 0,0 & 0,0 & & 0,0 & 0,0 \\
\hline 11 & 101,5 & 61,5586 & 702 & 1 & 0.1 & $\overline{61,6}$ & 2 & $\overline{0,3}$ & 123,1 & 17 & 2,4 & 1046,5 & & 0,0 & 0,0 \\
\hline 12 & 110,5 & 89,4261 & 537 & 4 & 0,7 & 357,7 & 0 & 0,0 & 0,0 & 8 & 1,5 & 715,4 & & 0,0 & 0,0 \\
\hline 13 & 120,5 & 114,361 & 510 & 1 & 0,2 & 114,4 & 0 & 0,0 & 0,0 & 9 & 1,8 & 1029,2 & & 0,0 & 0,0 \\
\hline 14 & 131,5 & 133,444 & 488 & 0 & 0,0 & 0,0 & 0 & 0,0 & 0,0 & 2 & 0,4 & 266,9 & & 0,0 & 0,0 \\
\hline 15 & 140,5 & 194,534 & 541 & 3 & 0,6 & 583,6 & 0 & 0,0 & 0,0 & 1 & 0,2 & 194,5 & & 0,0 & 0,0 \\
\hline 16 & 150,5 & 254,669 & 858 & 7 & 0,8 & 1782,7 & 0 & 0,0 & 0,0 & 9 & 1,0 & 2292,0 & & 0,0 & 0,0 \\
\hline 17 & 160,5 & 336,829 & 947 & 6 & 0,6 & 2021,0 & $\overline{0}$ & 0,0 & 0,0 & 2 & 0,2 & 673,7 & & 0,0 & 0,0 \\
\hline 18 & 170,5 & 405,477 & 1000 & 0 & 0,0 & 0,0 & 0 & 0,0 & 0,0 & 2 & 0,2 & 811,0 & & 0,0 & 0,0 \\
\hline 19 & 180,5 & 341,247 & 11119 & 4 & 0,4 & 1365,0 & 0 & 0,0 & 0,0 & 0 & 0,0 & 0,0 & & 0,0 & 0,0 \\
\hline 20 & 190,5 & 276,772 & 1239 & 3 & 0,2 & 830,3 & 0 & 0,0 & 0,0 & 5 & 0,4 & 1383,9 & & 0,0 & 0,0 \\
\hline 21 & 201,5 & 176,707 & 829 & 3 & 0,4 & 530,1 & 0 & 0,0 & 0,0 & 0 & 0,0 & 0,0 & & 0,0 & 0,0 \\
\hline 22 & 210,5 & 210,849 & 859 & 1 & 0,1 & 210,8 & 0 & 0,0 & 0,0 & 0 & 0,0 & 0,0 & & 0,0 & 0,0 \\
\hline 23 & 220,5 & 218,176 & 765 & 2 & 0,3 & 436,4 & 0 & 0,0 & 0,0 & 1 & 0,1 & 218,2 & & 0,0 & 0,0 \\
\hline 24 & 230,5 & 216,228 & 715 & 1 & 0,1 & 216,2 & 0 & 0,0 & 0,0 & 1 & 0,1 & 216,2 & & 0,0 & 0,0 \\
\hline 25 & 240,5 & 290,364 & 670 & 0 & 0,0 & 0,0 & 0 & 0,0 & 0,0 & 0 & 0,0 & 0,0 & & 0,0 & 0,0 \\
\hline 26 & 250,5 & 144,557 & 741 & 0 & 0,0 & 0,0 & 0 & 0,0 & 0,0 & 1 & 0,1 & 144,6 & & 0,0 & 0,0 \\
\hline 27 & 260,5 & 162,655 & 687 & 0 & 0,0 & 0,0 & 0 & 0,0 & 0,0 & 0 & 0,0 & 0,0 & & 0,0 & 0,0 \\
\hline 28 & 271,5 & 332,833 & 761 & 0 & 0,0 & 0,0 & 0 & 0,0 & 0,0 & 1 & 0,1 & 332,8 & & 0,0 & 0,0 \\
\hline 29 & 280,5 & 130,075 & 456 & 0 & 0,0 & 0,0 & 0 & 0,0 & 0,0 & 0 & 0,0 & 0,0 & & 0,0 & 0,0 \\
\hline 30 & 290,5 & 473,217 & 0,0 & 0,0 & 0,0 & 0,0 & 0,0 & 0,0 & 0,0 & 0,0 & 0,0 & 0,0 & 0,0 & 0,0 & 0,0 \\
\hline 31 & 314,5 & 334,253 & 0,0 & 0,0 & 0,0 & 0,0 & 0,0 & 0,0 & 0,0 & 0,0 & 0,0 & 0,0 & 0,0 & 0,0 & 0,0 \\
\hline 32 & 345,5 & 612,398 & 0,0 & 0,0 & 0,0 & 0,0 & 0,0 & 0,0 & 0,0 & 0,0 & 0,0 & 0,0 & 0,0 & 0,0 & 0,0 \\
\hline
\end{tabular}


APÊNDICE A - Difratogramas do sedimento da Lagoa Bonita

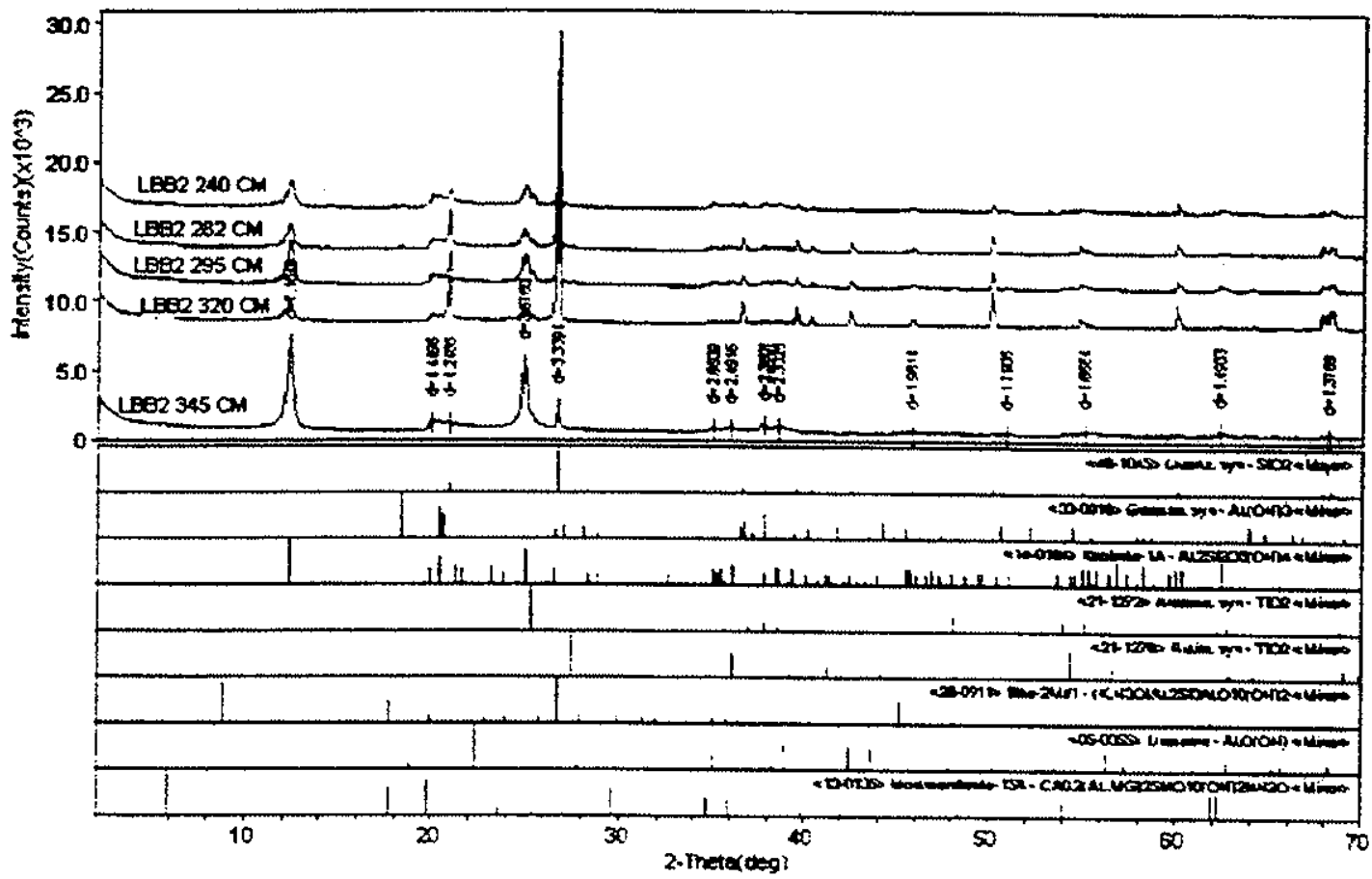

Lebortborio de DRX - IGUnB

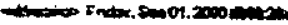

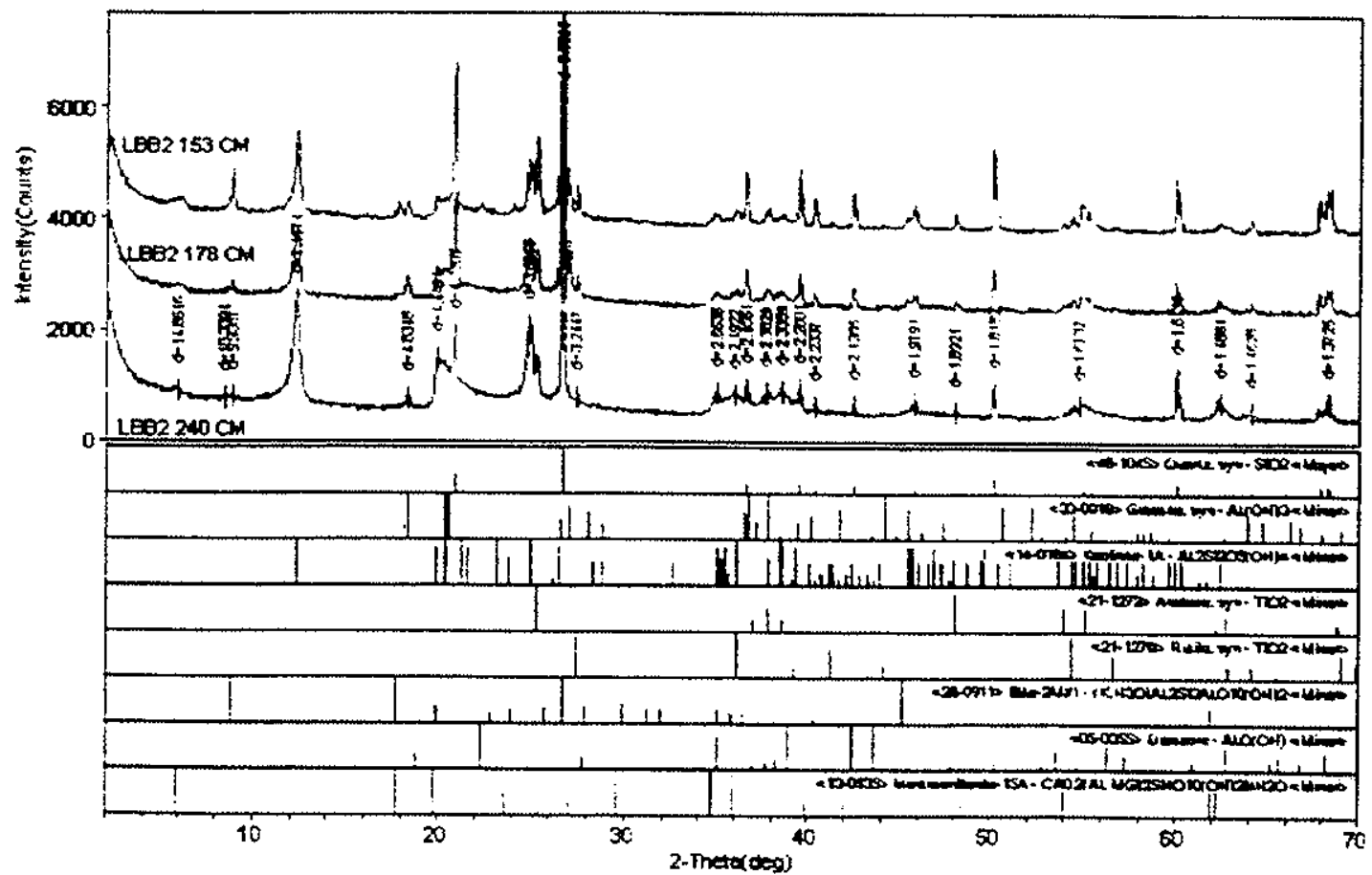




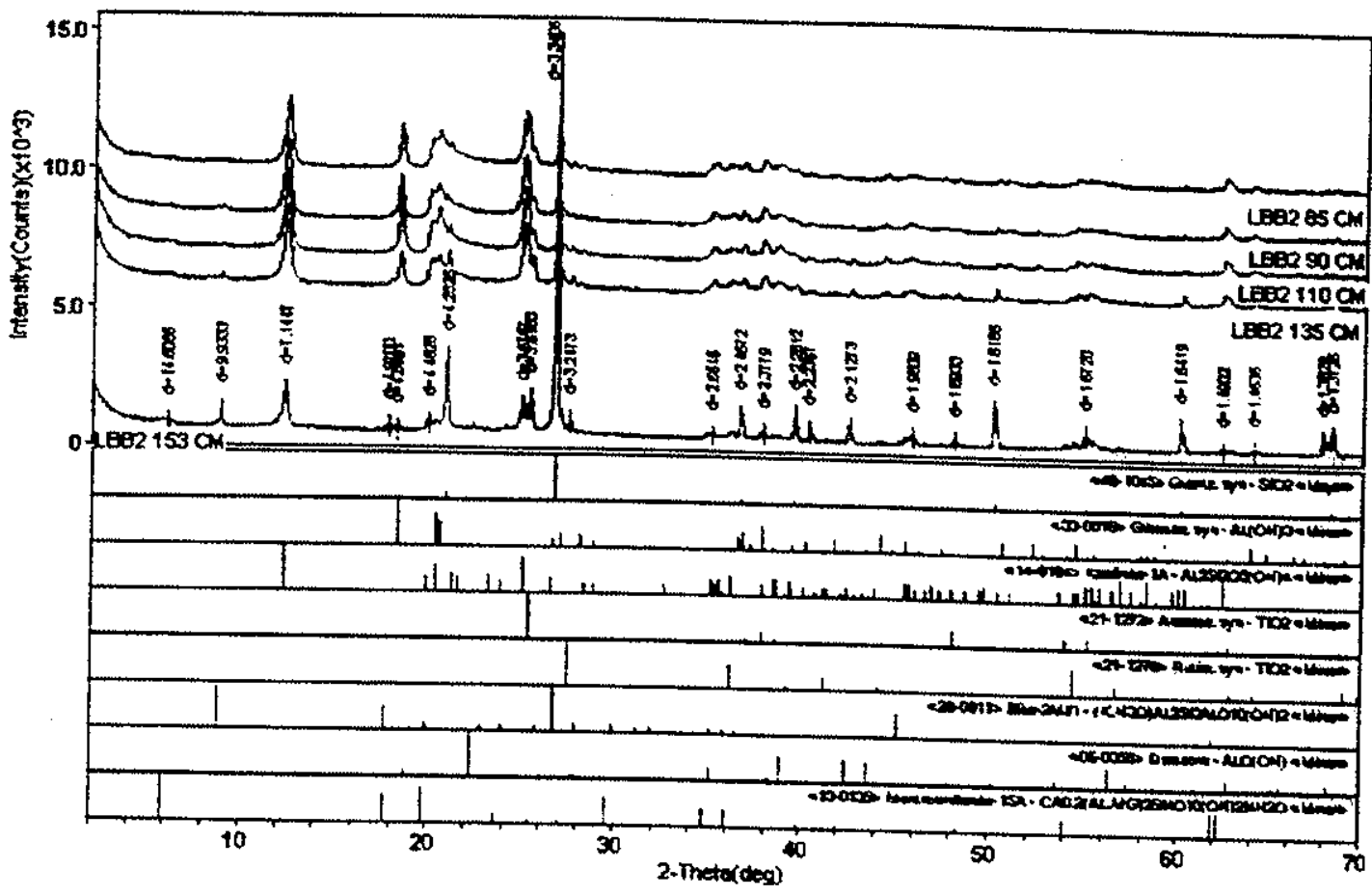

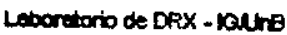

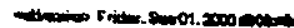

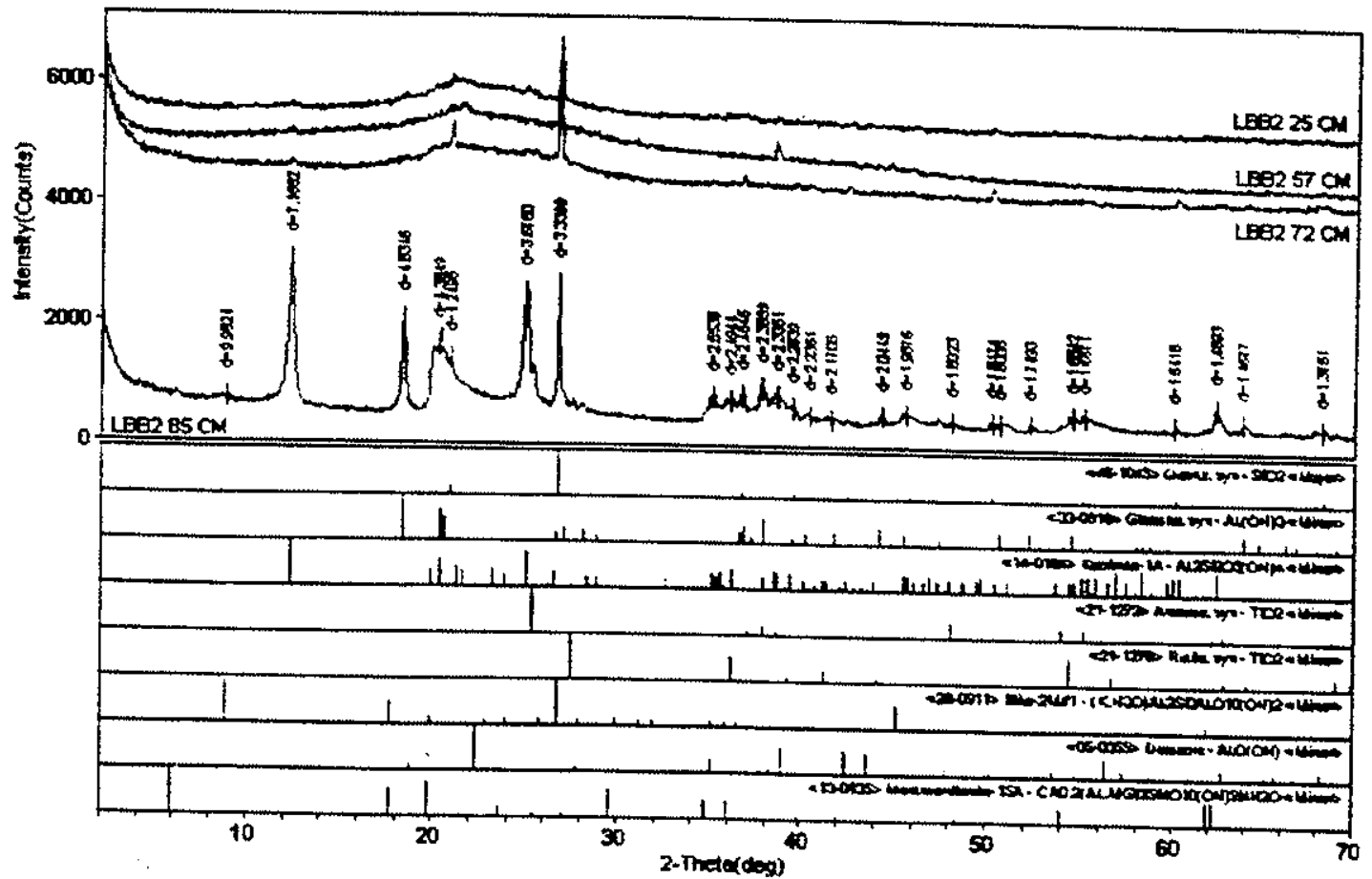

Labcraborio de DRX - sisung 